\title{
Testimony from the Nazi Camps
}

This interdisciplinary book analyses an important but under-researched corpus of testimonial accounts written by French women who were arrested and deported to Nazi concentration and death camps as political prisoners or because they were Jews. The corpus comprises some one hundred accounts published from the mid-1940s to the present day.

The book begins with an analysis of the status of the accounts and asks the following questions: who wrote the accounts? (including a discussion of the eye-witness, the nature of 'truth', memory and trauma); what is the status of these texts vis-à-vis the discourses of history and literature?; when were the accounts written and published?; what motivated the authors to write these texts? The author then shifts the focus by analysing the accounts as mediated textual constructs which draw on a range of literary and rhetorical paradigms and devices. This is followed by an examination of the representation of deportee identities, comprising an analysis of the construction of gendered and sexual identities, national, class, and political identities, and, finally, Jewish identities. The monograph concludes with a discussion of the work of Charlotte Delbo, whose testimonial accounts are reappraised in the context of the corpus as a whole.

Testimony from the Nazi Camps provides a fascinating discussion of testimonial literature within the context of contemporary debates relating to history, memory, and identity, and will be essential reading for students and academics of twentieth-century literature, history and the Holocaust.

Margaret-Anne Hutton is Senior Lecturer in French at the University of Nottingham. She is the author of The Novels of Christiane Rochefort: Countering the Culture (1998), Michel Tournier's Vendredi ou les Limbes $d u$ Pacifique (1992), and editor of French Fiction in the 1990s (2002) and Text(e)/Image (1999). She has published widely in the fields of contemporary French fiction and female-authored WWII testimonial accounts. 


\section{Routledge Studies in Twentieth-Century Literature}

1. Testimony from the Nazi Camps

French women's voices

Margaret-Anne Hutton 


\title{
Testimony from the Nazi Camps \\ French women's voices
}

\author{
Margaret-Anne Hutton
}

Routledge
(0)
Taylor \& Francis Group
LONDON AND NEW YORK 
First published 2005 by Routledge

Published 2017 by Routledge

2 Park Square, Milton Park, Abingdon, Oxon OX14 4RN

711 Third Avenue, New York, NY 10017, USA

Routledge is an imprint of the Taylor \& Francis Group, an informa business

Copyright (C) 2005 Maragaret Anne-Hutton

Typeset in Garamond by Taylor \& Francis Books Ltd

The Open Access version of this book, available at www.tandfebooks.com, has been made available under a Creative Commons Attribution-Non Commercial-No Derivatives 4.0 license.

British Library Cataloguing in Publication Data

A catalogue record for this book is available from the British Library

Library of Congress Cataloging in Publication Data

A catalog record for this title has been requested

ISBN 978-0-415-34933-8 (hbk) 
In memory of my maternal grandparents Eva Oks (née Baum) and Leon Oks, and all those members of my family who did not survive. 



\section{Contents}

Acknowledgements $\quad i x$

Introduction 1

PART I

$\begin{array}{ll}\text { Textual identities } & 7\end{array}$

1 Textual identities I: the epistemological status of the eye-witness account 9

Who wrote the accounts? 9

What are the accounts? 22

When were the accounts written and published? 35

Why were the accounts written? 42

2 Textual identities II: the accounts as textual constructs 51

Telling it as it was: truth, artifice and paradox $\quad 51$

'Un peu d'artifice': communication and reception 69

\section{PART II}

Deportee identities $\quad 101$

3 Deportee identities I: gender and sexuality 103

Female/male relations $\quad 105$

Same-sex relations 113

The female body $\quad 121$

'Feminine' preoccupations 130

Motherhood 136

Conclusion 140 


\section{viii Contents}

4 Deportee identities II: nationality, class, politics 142 National identities $\quad 142$

Class identities $\quad 160$

Political identities 166

5 Deportee identities III: Jewish identities 176

Imposed identities: Jewish otherness and specificity 177

Assumed identities: Jewish-authored texts 192

Republicanism and (imagined) communities 205

6 Conclusion: the case of Charlotte Delbo 210

Textual identities 210

Deportee identities 215

Canon vs margin? $\quad 218$

Notes $\quad 220$

Bibliography 235

Index 246 


\section{Acknowledgements}

My thanks to the ARHB for the research grant which contributed towards the funding of this project, to CPEDERF who supplied me with many of the primary texts, and to the Department of French at Nottingham University for additional funding. I am grateful also to the personnel working in the Centre de documentation juive contemporaine, the Fondation pour la mémoire de la déportation, FNDIRP and ADIR, all of whom were extremely helpful. Thanks above all to Rosemary Chapman, Máire ní Fhlathúin and especially Lucille Cairns, all of whom read and commented on initial versions of this book.

All translations are mine with the exception of works by Charlotte Delbo cited in Chapter 6. 



\section{Introduction}

According to historian Henri Rousso, France's 'obsession' with the Vichy years began in the mid-1970s (1990: 19). Six years later Vichy, un passé qui ne passe pas (Conan and Rousso 1996) reminded us that the 'dark years' remained very much in the public eye throughout the 1990s, kept alive by a series of highly mediatised events: the trials of Vichy functionaries René Bousquet (assassinated in June 1993 before coming to trial), Paul Touvier, and Maurice Papon; the apparent discovery of the 'Jewish file' (le fichier juif); the heated controversy surrounding then-president Mitterrand's annual laying of a wreath on Pétain's tomb and his handling of the Vel d'Hiv commemoration, followed some two years later by the calling into question of the president's Resistance credentials; debates surrounding the status of Resistance heroes Jean Moulin and Lucie and Raymond Aubrac; President Chirac's (more successful) management of the Vel d'Hiv commemoration, and the scandal surrounding 'father Pierre'. ${ }^{1}$ Unsurprisingly, given this (far from comprehensive) list, ${ }^{2}$ Conan and Rousso conclude that France's 'obsession' is still very much alive.

Obsession, they remind us, can be a dangerous thing. In their eyes, France's continued fascination has led to anachronistic representations of the Vichy years; a skewed history of the period and the generation of 'new blind spots' with respect to how France's past is viewed (Conan and Rousso 1996: 18). Media-driven 'revelations' are, they further suggest, in fact 'pseudo-revelations': the Vichy period 'is today anything but taboo' (ibid.: 35-6). While these claims are undoubtedly well founded, the fact remains that some voices have yet to emerge from the white noise; 'blind spots' unidentified by Rousso and Conan also exist. For all the focus on the Vichy years, and in spite of the apparently growing importance of the witness ${ }^{3}$ (actually largely restricted to the courtroom and the media), the testimonial accounts of a particular group of individuals who suffered the consequences of the 


\section{Introduction}

Vichy regime - French women deported to Nazi concentration and death camps - have, as yet, received next to no critical attention. ${ }^{4}$

Nor, indeed have they impinged on public consciousness. Mention Nazi concentration camp testimonial accounts and your interlocutor will probably name Primo Levi. Narrow it down to francophone accounts, and in all likelihood Robert Antelme, David Rousset, Jorge Semprun and Elie Wiesel will be cited. Push the issue a little further to accounts written by French women and the name of Charlotte Delbo may emerge. This limited popular repertoire, very much echoed in academic circles, reveals both an anglophone bias - many of these writers' works will have been read and studied in translation - and a focus on male-authored texts. Until the last two decades of the twentieth century, critical work on deportation and testimonial accounts was either male-normative or gender-blind. Research into women's testimonial accounts took off in the United States in 1980s and 1990s, but has yet to expand into France or to analyses of francophone accounts. ${ }^{5}$ Focus has, furthermore, fallen very much on Jewish deportees and their writing: while 'Holocaust studies' is a growth industry, considerable work remains to be done on testimonial accounts authored by non-Jewish deportees. In fact, in spite of claims that focus on the Vichy years has become increasingly 'judeocentric', Jewish testimonial accounts written by French women have also been somewhat neglected.

So precisely which French women's testimonial accounts does this present study seek to analyse? Two principal categories of prisoners were deported from France: those arrested and deported as Jews, and those arrested and deported as 'political' prisoners. The majority of women whose accounts are analysed here were deported between 1943 and 1944, the Jews to Auschwitz-Birkenau and the 'political' deportees ${ }^{6}$ to Ravensbrück, though in nearly all cases deportees had passed through several camps by the time they were liberated. Serge Klarsfeld's meticulous reconstruction of lists of convoys sent from Drancy to Auschwitz places the total number of Jews deported from France at 75,721 , of whom only 3 per cent returned. Of this total, approximately 8,637 women were not selected for the gas chambers immediately upon arrival in Auschwitz, and only 740 women were still alive in $1945 .^{7}$ Statistics for political deportees are - symptomatically - yet to be firmly established, though efforts to remedy the situation are well underway. ${ }^{8}$ Although no breakdown by sex is as yet available, existing figures estimate that approximately 63,085 individuals of both sexes were arrested and deported from France as political prisoners, of whom some 59 per cent returned. ${ }^{9}$ The corpus of texts 
studied here comprises just under 100 testimonial accounts, of which approximately a quarter were written by Jews. For the sake of easy (or relatively easy reference) and to preserve this author's sanity, only published texts have been included in the corpus, though many more unpublished accounts, as well as oral and video testimonies exist, while the vagaries of catalogue subject-searches are such that further published accounts can inevitably also be located.

I have attempted in what follows to do (at least) two things: first, to allow the deportees in question to 'speak for themselves' to some extent by quoting from their works quite extensively, although not, of course, uncritically; second, to adopt an inter-disciplinary approach which will, I hope, result in as comprehensive an analysis of these accounts as possible. Given that so-called Holocaust theorists have had rather more public exposure than the deportees (the names of Blanchot, Derrida, or Lyotard, to name but some, are more likely to trip off the tongue than those of, say, Bouteille-Garagnon, Dufournier, or Lévy-Osbert), and given that much of what they have to say about the 'unspeakable' nature of the camps seems curiously at odds with the concrete nature of the spoken-of lived experience of the deportees (both Jewish and non-Jewish), I have avoided abstract theorisation - doubtless a bias of my own.

The study which follows is divided into two Parts and five chapters, each of which should ideally be read in light of all the others. Part I, which focuses on the epistemological status of the testimonial accounts, opens with an analysis of intentional (authorial) claims for, and descriptions of, the nature of the testimonial enterprise, and aims to analyse such claims in the light of competing discourses. The following key questions are explored from the point of view of the deportee authors themselves and that of historians and critics in the field of testimonial writing: what is the status of the eye-witness (including a discussion of memory and trauma)? How is 'truth' defined in the context of the testimonial account (where do we situate such texts in relation to the discourses of history and literature)? When and why were the accounts published? The second chapter, which complements the first, changes the angle of approach by turning away from authorial intention to the moment of reception, analysing the accounts as mediated textual constructs. In spite of the authors' claims that their testimonial accounts are 'not literature' and indeed not literary, the nature of the genre is such that alongside various authorial attempts to align the texts with non-literary genres and paradigms, literary and rhetorical devices (from direct speech to apostrophe, humour to metaphor) are deployed in all these accounts, 


\section{Introduction}

both successfully and less successfully as regards the ultimate aim of achieving verisimilitude.

Part II and the next three chapters comprise an analysis of the construction and representation of deportee identities. Each chapter focuses on one or more specific areas of identity construction but, again, is intended to contribute to a composite picture when set aside the other chapters in this section. Chapter 3, which opens with a brief discussion of challenges to gender-based approaches to this field of study, goes on to explore how 'women in the camps' actually constructed their gendered and sexual identities. This and subsequent chapters serve to remind us both of the importance of avoiding essentialising claims (various discourses in fact intersect in the construction of gendered and sexual identities) and of the fact that the accounts are, as well as mediated textual constructs, produced by ideologically situated subjects. Chapter 4 turns to the representation of national, class and political identities, picking up on and developing the notion of the construction of complex subject-positions. We thus move from just 'women' in the camps to 'women of certain class, and with specific political allegiances, who seek to represent their belonging to a certain construct of national identity'. Chapter 5, which focuses on the construction of Jewish identities, highlights the often difficult negotiations of national and Jewish identities, and, importantly, reminds us that although the accounts of both Jewish and non-Jewish deportees in the corpus have much in common, the very real differences in terms of the experience of each group in the camps should by no means be underestimated. Finally, by means of a conclusion in Chapter 6, the testimonial accounts of the only French female deportee to have achieved a degree of critical and public recognition - Charlotte Delbo - are reassessed in the light of the corpus.

If the analysis of textual and deportee identities constitute the subject matter of this book, then one further identity should perhaps finally be touched upon: this author's. LaCapra reminds us that those working in the field of Holocaust studies must be alert to the possibility of the existence of a transferential relation to their object of study; the tendency unwittingly 'to repeat, at least discursively, the processes one studies as a researcher' (1994: 206): ${ }^{10}$

Whether the historian or analyst is a survivor, a relative of survivors, a former Nazi, a former collaborator, a relative of former Nazis or collaborators, a younger Jew or German distanced from more immediate contact with survival, participation, or collaboration, or a relative 'outsider' to these problems will make a 
difference even in the meaning of statements that may be formally identical. Certain statements or even entire orientations may seem appropriate for someone in a given subject-position but not in others.

(ibid.: 46)

Although this book extends beyond the strict definition of the term 'Holocaust', embracing as it does texts written by non-Jews as well as Jews, the possibility that the same potential process is at work in my research cannot of course be discounted. LaCapra's solution to the problem of the analyst's 'acting out' rather than 'working through' lies in the somewhat intangible aim of their maintaining a position of theoretically informed awareness of the potential problems at stake (ibid.: 71). Although he further suggests that a 'show-and-tell session or even a movement toward autobiography, particularly when that movement is strained, trivializing, or self-indulgent in view of the object of inquiry' should be avoided (ibid.: 210), I nonetheless offer the brief self-indulgent statement that I am a third-generation relative on my mother's side of both survivors of the Holocaust (who left Eastern Europe for the UK in the 1930s) and victims (who did not); a secular Jew, born in Paris and brought up in France until the age of six, with a Scottish father. These biographical factors without doubt contributed to my decision to write this book; any further impact they or other facets of my identity may have had is for others to judge. 



\section{Part I}

Textual identities 



\section{Textual identities I \\ The epistemological status of the eye-witness account}

This opening chapter approaches the corpus via a series of four interlocking questions: who wrote the accounts?; what is their status

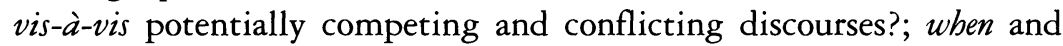
why were they written? Emphasis is placed on authorial statements located either in paratexts or embedded in the main body of the accounts. These intentional assertions are placed in a dialogue with contemporary debates relating to historiography, memory and identity. The fact that the authors of the accounts occupied complex subjectpositions relating to gender, sexuality, nationality, class, political affiliation and identification with Judaism has been bracketed until Chapters 3-5. Equally, the status of the accounts as textual constructs comprising formal, narrative and rhetorical strategies is deferred until Chapter 2, which thereby constitutes a complement and balance to the focus on authorial intentionality explored here.

\section{Who wrote the accounts?}

\section{The truth, the whole truth, and nothing but the truth}

To begin with the apparently obvious, the accounts were written by eye-witnesses, by those who had seen at first hand the events about which they were subsequently to write. As such, they may be considered as testimonial or witness accounts: but how appropriate is the courtroom paradigm potentially invoked by such terminology? In the context of the court, the witness is regarded as one who will tell 'the truth, the whole truth and nothing but the truth', this promissory claim to veracity and integrity being 'guaranteed' via the legal process of swearing in. An awareness of, and indeed desire to adopt, this legalistic paradigm are suggested in the vast majority of the accounts via prefatory or other metatextual statements made either by the authors 


\section{Textual identities I: eye-witness accounts}

themselves or by third parties who introduce their work. Such statements frequently include the descriptors 'witness' and 'witness account', as well as phrases relating to the intention to testify with the utmost integrity: 'I will limit myself to the facts' (Dufournier 1945: 13); 'I wished only to report with utmost sincerity that which is so deeply inscribed in my heart and in my memory' (Abadi 1995: 10); a reminder of the author's 'unwavering determination to state the facts and nothing but the facts' (Busson 1946: 9).

As Dulong points out in his Le Témoin oculaire, a sociological analysis of eye-witnessing as a performative institution, authorial intentionality may be an important consideration: in order to accept a narrative as the description of something that actually happened we must be sure of its author's intention to bear witness ["témoigner"]' (1998: 45). In the case of this corpus, such intention is not in doubt. Equally significant is the fact that the accounts were not only intended as 'witness statements' at the time of their production; often, the deportees' intention to testify at a later date was already in place while they were in the camps, a fact which is again identified as crucial - and unusual - by Dulong: 'individuals are inevitably caught up in the present moment of events, they are not thinking ahead to some future narrative or cross-examination' (ibid.: 34). Blanc's citation of the words of a fellow-deportee typically signals the authors' desire to note events as they unfolded: 'I know that you're recording everything about our time here in Germany' (1984: 190). Le Guillerme stresses the fact that she observed events with great care in order that she might recount her experiences at a later date: 'I'm exercising my memory; it's a good idea to keep a mental journal if I want to write an account of what we've been through later' (1946: 201). The journal, in fact, was in many cases more than merely a mental one: as we will see in Chapter 2, a number of deportees describe their accounts as journals written in the camps, while many more kept notes for the express purpose of reinforcing accuracy and recall with the aim of writing up an account once they had regained their freedom.

The intention to recount truthfully is therefore in place, but how is this testimonial 'truth' defined? The deportees articulate it in two principal ways: in opposition to the discourses of literature and history (the latter is discussed below in the section 'What are the accounts?'); and in terms of the all-important and oft-repeated verbs 'to see' and 'to experience/live through' ('vivre'). Most of the deportees, or those prefacing their work, stress the non-literary - and thus by implication non-fictional - status of their accounts, seeking to highlight what Ricœur refers to as 'the essential difference between the image of the 
absent as imaginary, and the image of the absent as anterior' (2000: 306). In the pursuit of truth, the literary must be avoided at all costs: 'Here is the most unaffected, the most truthful account of Nazi Germany's concentration camps; a work utterly devoid of the frivolity of literature' (Renault 1948: 7). Wilborts states in similar vein that 'the following record has only one virtue: it is an account of something I lived through' (1946: 15), while M. J. Séverin, prefacing MoriPerrin, asserts:

This is not what is called a 'literary work'. What you have written comes from your heart, your memory, your character, your experience... and that is as it should be. What you have to say is sufficient unto itself. Because your account has a profound value as testimony.

(1992: unpaginated)

As we will see later in this chapter, and in Chapter 2, claims emphasising the non-literary status of the accounts evidently cannot be taken at face value: postmodern theorists remind us that clear-cut boundaries between discourses are untenable; authors may define their work in opposition to the literary, but no text appears ex nibilo, and the deportee writers cannot and do not avoid recourse to literary devices and paradigms.

The second authorial definition of 'truth' rests on the verbs 'to see' and 'to live through', and indeed these twinned appeals to authenticity are often set in opposition to literary discourse: 'I don't claim to have written a literary work. I've seen some sad, often terrible things ... What follows is simply an account of what I've seen and lived through' (Birnbaum 1946);' 'I don't intend to write a literary work, but simply to say what I've lived through, what I've seen' (Schapira 1994: 35). This juxtaposition of the two verbs ('to see' and 'to live through') highlights a fact which is often under-emphasised: the deportee eye-witnesses were not merely observers of third party acts, but participants in a lived experience. As Grinspan states appositely: 'Those of us who returned are witness-protagonists' (Grinspan and Poirot-Delpech 2002: 232). This dual quality of observer and participant serves to modify another potential paradigm, that of 'reportage'. While several accounts use this term (Toulouse-Lautrec points out that her 'talent as a reporter' was recognised by editors, 1967: 10; Blanc states in her Foreword 'I have written a piece of reportage', 1984, her emphasis), the reality of the situation is perhaps best captured by the description of the accounts as 'lived reports' (Saint-Clair 1945: 13). 


\section{Textual identities I: eye-witness accounts}

The physical presence of the witness on the scene, already signalled by the verb 'to see' and further reinforced by the verb 'to live through', has another crucial function. In his analysis of the status of the eyewitness, Dulong suggests that, in the context of the everyday or conversational paradigm of eye-witnessing, the statement 'I was there' serves a performative function, representing a variant on the promise, and constituting the witness as witness (1998: 168). Most relevant to us here, Dulong goes on to suggest that it is this somatic continuity which helps guarantee a position of belief vis-à-vis the witness: "by saying "I was there", the witness designates his body as proof of biographical identity, as the medium which guarantees temporal continuity' (ibid.: 186). The somatic presence of the witness may itself assume an evidential status: 'In a way he [the witness] is the trace, he designates his body as a "speaking trace" of the event' (ibid.: 173). Annette Wieviorka, citing Haïm Gouri on the subject of the witnesses at the Eichmann trial, raises a not dissimilar point: 'They were the very essence of the trial, because they were the authorised representatives of the Holocaust. They were the facts' (Wieviorka 1998: 114-15). ${ }^{2}$

In both of these cases, of course, the reference is to oral testimonies and not written texts. While this is obviously a critical distinction, the importance of the somatic is recognised (if not explicitly) by the writers of the accounts. Repeated references to the body and inscriptions on/in the body seem to indicate an unmediated truth; somatic references not only assure continuity in time (the body writing is the same body which was present in the camps), but seek to underline authenticity. Thus, typically, in Grinspan's J'ai pas pleuré, co-written with Bertrand Poirot-Delpech, the latter states: 'This account will be Ida's, it will bear her face, her voice, it will be as she lived it in the flesh' (2002: 12, my emphasis), ${ }^{3}$ while Serre makes the distinction between 'fictionalised books, films which manipulate the truth' and 'those who really lived through it and who suffered, in their hearts and in the flesh' (1982: 5, my emphasis). As if further to stress somatic continuity as a guarantor of authenticity, Picard conflates bodily experience with the writing act itself: 'Alas, there were millions of us who wrote this History, with our sweat and with our blood' (1995: 134, my emphasis).

If these examples place the emphasis on 'the flesh', another recurring motif is that of the heart: 'You have written from the heart' (preface to Mori-Perrin); Busson's writing is described as having 'the merit of being sincere in its translation of the emotions of a woman's heart' (1946: 10). Traditionally the heart is linked to sincerity - oaths may be sworn 'hand on heart', national anthems sung with the hand placed over the heart - but it is also regarded as the seat of the 
emotions, and this raises another crucial factor relating to eye-witness testimony, namely that of affective response. Whereas in the courtroom the witness at the stand is expected to remain objective, detached and unemotional, and may indeed be rehearsed to be so (Dulong 1998: 36), the same is not true of the everyday conversational paradigm:

Someone who, in a casual conversation, tried to de-subjectivise the account of what happened to them would come across as abnormally distant, they would exhibit an immoral if not pathological coldness. Mentioning one's affective response could be said to be a vital part of ordinary witnessing, a means of signalling the very reason for recounting the event in the first place.

(ibid.: 35)

Dulong further suggests that historians may spurn eye-witnesses not so much for reasons of cognitive inaccuracies or memory failings, but precisely because of 'an inability to disengage from the heat of the moment' (ibid.: 216). Deportee writers may well find themselves faced with a dilemma, trapped between two opposing paradigms. On the one hand, the events they recount are deeply shocking and emotive. These are events which in a conversational paradigm would be expected to carry a powerful emotional charge. Yet in their writing of the accounts the deportees appear to seek to adhere primarily to the courtroom paradigm of the eye-witness, not only stressing their objectivity, but for the most part adopting a resolutely dispassionate tone. ${ }^{4}$ Primo Levi famously articulates what remains implicit in these accounts:

I have deliberately assumed the calm, sober language of the witness, neither the lamenting tones of the victim nor the irate voice of someone who seeks revenge. I thought that my account would be all the more credible and useful the more it appeared objective and the less it sounded overly emotional; only in this way does a witness in matters of justice perform his task....

(1987: 382)

A lack of affect is consistently equated with truth. It may be that frequently reiterated metatextual and paratextual references to the heart serve as a counterbalance to this detached tone, reminding the reader of the emotional and subjective charge which has been deliberately expunged from the body of the text in order to increase verisimilitude and thereby maximise credibility. 


\section{Textual identities I: eye-witness accounts}

\section{Reception}

Not just the reader's belief, but also the audience's very presence is imperative in the context of deportee accounts. The eye-witness's intention to testify may be in place, but as Dulong suggests, a receptive audience is required before the eye-witness is truly constituted as such. This audience must fulfil two conditions: it must be interested in what the deportees have to say (if, as he states, the answer to 'I promise' is 'so what?', the contract fails, 1998: 175); and it must have faith in the witness. As Ricœur, glossing Dulong, puts it: "The witness does not merely say "I was there"; he adds: "Believe me"' (Ricœur 2000: 205). In this sense, 'truth' becomes contractual; only a receptive community of listeners - or in this case readers - can make the witness a witness: 'The testimonial account is only fully validated when and if the audience accepts it; henceforth the testimonial account is not only validated, it is accredited' (ibid.).

The presence of such a receptive audience proved to be problematic for the deportees. Even the first wave of writers anticipated a certain indifference to what they had to say. Roux, writing in 1946, pre-empts her readership's response with a weary: 'these are just words you've already read over and over, aren't they?', referring even at this early stage to 'the classic tale of all the camps' (ibid.: 179). Later writers' anxieties more often centre on a fear both of a saturated market and a reduction of 'relevance': 'More and more books are being published. True, many fewer now on the subject of deportation. Is the subject unfashionable these days? Is it no longer "relevant"?' (Jacques ChabanDelmas, Foreword to Valois, 1969). Those writing most recently often explain their protracted silence by evoking perceived pressures in the post-liberation years to keep their stories to themselves: 'No-one actually told me to "shut up". But the taboo was so strong that I never alluded to my memories of the camps' (Alizon 1996: 374).

Indifference to what the witnesses had to say, however, was not the only problem faced; credence for what was being said was potentially fraught with difficulty. As Dulong points out, although there are recognised epistemological issues surrounding both the moment of visual perception and that of recall, societal practice is very much at odds with theory with respect to the eye-witness account, for the norm or 'default position' in an everyday conversational paradigm is to believe first-person accounts as true (1998: 14). But as both he and Ricœur indicate, eye-witness accounts of the Nazi camps represent something of an exception: 'Some witnesses never find an audience capable of listening to and hearing them' (Ricœur 2000: 208). 
Paradoxically, to be worth the telling an event must be out of the ordinary, yet the very exceptionality of the experience may tilt the delicate balance between the plausible or believable ('le vraisemblable') and the implausible or unbelievable ('l'invraisemblable'): 'The paradox of the witness ... is that both his fitness to speak and the likelihood that he will be criticised increase in direct proportion to his account's departure from the ordinary' (Dulong 1998: 68). Recognition of the potential impasse in which deportee authors find themselves abound in the accounts. Many express the fear that they will quite simply not be believed: 'I couldn't talk about it, I couldn't say anything, and besides people wouldn't have believed me, they would have thought I'd gone mad. So like the other deportees, I kept quiet' (Schapira 1994: 122).

Often it is the incommensurability of two worlds and two groups of people - those who have been there and those who have not - which is stressed: 'we pledged in the camps that we would say nothing, because we knew that no one, no one among the living, would be worthy of sharing in our terrible secrets' (Roux 1946: 36):

Even if I were to tell you all this, and much more, you would still know nothing; luckily for you, all of this will remain remote from you, because only we can ever know what our life was like, and we don't want to share it with anyone.

(Aylmer-Roubenne 1996: 52)

\section{Identity, memory, trauma: the deportees' point of view}

The articulation of a breach opening up between the deportees and those around them is widespread in the accounts. Those who returned had undergone a fundamental change, what might almost be termed a paradigm shift. And that radical dislocation extended further, for the chasm of incommensurability applied not just to two worlds, or two groups of individuals (those who had experienced deportation and those had not): it extended to the deportees' own sense of identity. The returned deportee was not the woman she had been. The writing self was often distanced and disconnected from the written self. 'Who wrote the accounts?' (and about whom?) is a question which must be revisited.

A simple marker of personal identity - the proper name - serves as reminder that the circumstances of war were such that for many, public and private selves were already labile and polymorphous. As Aylmer-Roubenne states: 'nothing could be taken at face value; beneath appearances might lurk a hero, a rogue or a torturer!' (1996: 


\section{Textual identities I: eye-witness accounts}

20). Deportees involved in Resistance activities found themselves armed with false identity papers, and assumed false names. Situations could become more than somewhat complicated. When Lesèvre, operating out of Lyons under the code name 'Madame Séverane', was interrogated by Klaus Barbie, she found herself accused of being another agent, 'Didier': 'She chose to deny absolutely the person whom she was not, to try and avoid, were Barbie to discover the truth, having to deny who she really was' (1987: 17). Friang, operating under two code-names, Brigitte and Galilée 2, reveals that her Resistance experiences were to have a definitive effect on her identity:

What I could not anticipate was that ... my participation in the Resistance would not merely carve out a channel of continuity in my life, but that taking me as the raw material, it would fashion a character who would never have emerged without that participation. The fact that I did not use my name Elizabeth again after the war, a name I actually much prefer to Brigitte, proves the point.

The co-existence of multiple names is, of course, merely a surface marker of a deeper truth which applies to any autobiographical enterprise, but which perhaps has more profound ramifications in the case of deportee accounts, namely that the individual who writes the account cannot simply be equated with the written-of self. Returning from a strange country, the deportees who recorded their experiences were often acutely aware of the presence of two selves utterly divorced one from the other. Self-objectification and the articulation of distance or a gap between two worlds, two times, two selves, are characteristic of many accounts. When asked about her experience of being beaten in the camps, Crémieux separates out these two selves for the first time: 'I was no longer a deportee, I observed my life as a deportee' (1999: 116). Guillemin-Ducret articulates the common sensation of alienation from her narrated self: 'I sometimes still ask myself if the person who lived through those times was really me!' (1986: 55). In some cases the two selves (returnee and deportee; author and actor) co-exist uneasily: 'I think I see a long and empty road in front of me. A shadow stretches along the road, a shadow which I recognise with alarm, my shadow from back there' (Roux 1946: 221). Maurel, for her part, cannot quite bring herself to ascribe subject status to this 'other' deportee self: 'Officially it's true, I came back. But what was it that really came back?’ (1957: 185). 
Self-objectification may manifest itself otherwise than in explicit statements. Although the vast majority of the accounts are written in the first person, occasional uses of the third person underline the gap between the 'who' writing and the 'whom' written. Wilborts refers to herself predominantly as either 'she' or 'the woman', restricting the first person for the most part to observations made from the standpoint of the returnee or writing self. Although Fabius writes in the first person, her account opens with a description of her first, shocking, experience of hard labour: 'One of these shadows seems to move more slowly, with even less confidence than her companions. It's a woman who a few months earlier was in the full bloom of her thirties' (1986: 16). The rest of Fabius's account is narrated in the first person. In similar fashion Blanc begins her account in the third person with a description of her arrest and interrogation, referring to herself as either 'she', 'madame B...', or 'the young woman', before shifting definitively to the first person. In other cases a more complex pattern emerges. Mori-Perrin's account opens in the first person with an account of her grandchildren inviting her to recount her experiences in Ravensbrück, then shifts to an objectifying third person - 'And so Madame de Mori, alias Perrin, said to herself that she really had to bring herself to tell them about it one day' (1992: 9) - before returning to the first person.

Complexities are not restricted to the gap between the writing and written self: the majority of accounts stress the fact that the latter was itself fragmented and polymorphous. Davidovici writes of her first moments in Auschwitz: 'I felt completely alienated from myself, as if I'd split into two people' (1998: 22). One of the most widespread observations relates to the need to adopt an attitude of passivity in the camps; the importance of maintaining a public self characterised by compliance and utter self-effacement. As Hollander-Lafon states: 'Very quickly another me is created: a small, docile, striped shorn sheep, jostled towards a fragile fate by big black beasts with sharp teeth' (1977: 19). Le Guillerme notes the changes in her own personality: 'no one ever pushed me around in civilian life ..., I'm an awkward character, but since I've been in Fresnes I feel as if I'm losing myself day by day' (1946: 86). While appearing outwardly compliant in the face of the SS, the deportees were also obliged to cast off fragilities and vulnerabilities. Brun records her metamorphosis from 'the docile wellbehaved little girl' to 'a real tigress' when faced with Polish deportees seeking to steal from her (1979: 188). Coping with the realities of life in the camps often meant dissociating from a previous self. When Brun pushes a dead body out of the way in the camp hospital block, she is horrified by her own lack of response: 'I'm utterly devoid of 


\section{Textual identities I: eye-witness accounts}

feeling, my heart is made of stone; I'm cocooned, completely detached from the world' (ibid.: 166).

Deportees, who were often very young, had to grow up fast. Many point to the dissolution of the child or thoughtless young adult who had inhabited their previous self. When she is struck for the first time in her life during interrogation, Carliez-Lambert de Loulay realises that her 'usual spoilt-brat style was now a thing of the past' (1945: 22). For those who were still minors when deported, the loss of parents triggered particularly acute crises of identity. Aged just fifteen when she was deported then separated from her mother in Auschwitz, Heftler was forced to forge a new identity: 'Up until that point ... I didn't exist, I had no personality, no inner strength, I was just mummy's little girl' (1992: 68). In some cases severe illness or exhaustion produced an almost psychotic loss of sense of self (Abadi 1995: 130; Hautval 1991: 46). The dislocation of identity was not usually this extreme. More commonplace are descriptions of enforced anonymity as individuals, reduced to 'Stücken' in eyes of the camp authorities, were duly labelled and numbered. References to the assignation of a 'matricule' or camp-number can be found in the majority of texts: 'A little twenty-year-old French girl, lost in the depths of Germany, now I was nothing but a Number: 19. 374' (GuilleminDucret 1986: 72). Outwardly a mere statistic, deportees fought to preserve a sense of self. For some, the 'matricule' was perceived as a much-needed means of protecting one's 'true' identity: 'The number is our disguise. A meeting of masks. The human being who lurks behind it does her best to hide what she used to take a voluptuous pleasure in displaying: her soul' (Novac 1996: 17).

\section{Identity, memory, trauma: the critics' point of view}

The deportees' explicit references to the experience of self-objectification and the co-existence of more than one 'self', echo observations made by critics such as Langer, Felman and Laub in their explorations of trauma, memory and identity. All of these critics, in slightly modulated ways, can be said to challenge definitions of 'who wrote the testimonial accounts?'; potentially to call into question those truth

claims made by the deportees, which, as was seen above, are based on both the importance of lived experience and the status of the accounts as non-literary. In his influential Holocaust Testimonies: The Ruins of Memory, Langer differentiates between two types of memory: 'deep' and 'common' (1991: 7). ${ }^{5}$ The first of these has the following characteristics: it is inaccessible to willed recall; it is a-chronological (deep 
memory surges up unbidden, it disrupts the flow of common memory); it resists narrativisation; it is unintegrated into understanding ('I'-now and ' $\mathrm{I}$ '-then cannot be unified into a coherent self). Common memory, by contrast, is accessible to willed recall, seeks to secure a detached view of the self as it was then; is integrated into understanding; is open to narrativisation. Correlative to these two memory types are what Langer describes as parallel, co-existing 'voices' or 'selves', both of which can be identified in the testimonial account.

Langer's typology of memory allows for the possibility that although certain events may be seen ('voir') and indeed directly experienced ('vivre'), they may subsequently become inaccessible to willed recall. The self who acted in certain ways may subsequently be lost to the writing self; events witnessed may become, quite literally, unspeakable. That which cannot be re-presented in memory cannot be represented. Eye-witness accounts, in other words, may be necessarily, if unwittingly, expurgated. More than this, accounts may be unknowingly distorted. Calling upon common memory, the deportee recounts a version of events which allows her to represent an integrated vision of herself. As Langer states of common memory: it restores the self to its normal pre- and post-camp routines but also offers detached portraits, from the vantage point of today, of what it must have been like then' (ibid.: 6). Deportees may accentuate the positive; accounts may be edulcorated versions of 'the truth': 'One effect of common memory, with its talk of normalcy amid chaos, is to mediate atrocity, to reassure us that in spite of the ordeal some human bonds were inviolable' (ibid.: 9). A chronological narration of events, finally, masks the anarchic atemporality of deep memory: 'Being possessed is "now"' (ibid.: 174).

These concepts do more than potentially undermine truth claims based on the eye-witness's lived experience; they also unpick the distinction between the literary and the non-literary: chronology is revealed as an artifice, and so is the narrative voice through which the ventriloquist-author speaks (ibid.). But Langer's approach must be examined with circumspection, especially his treatment of oral and written testimony respectively. The distinction drawn between deep and common memory in Holocaust Testimonies: The Ruins of Memory is based primarily on oral testimonies, and it is the latter which Langer ultimately privileges as a means of accessing 'truth'. ${ }^{6}$ It is both the immediacy, and, crucially, the presence of an active interlocutor, which allow deep memory to emerge: 'These interviews [with deportees] repeatedly touch exposed nerves that the witnesses themselves did not realize existed, resulting in an immediacy of introspection that could probably be captured nowhere else' (ibid.: 31). Here Langer is close to 


\section{Textual identities I: eye-witness accounts}

Felman and Laub when they refer to 'the impossibility of witnessing' and claim that certain material can only emerge in a dialogic situation. It is oral testimony, Laub claims, which leads to the 'unearthing of ... something neither known nor articulated before'; to 'what is not yet known, what becomes enacted in the moment of testifying' (Horowitz 1992: 54-5).

According to this standpoint, the eye-witness status of the writer is not a sufficient guarantee of 'truth'. Langer's emphasis on orality, however, is open to criticism on several grounds. The binary construction of 'deep' and 'common' memory, like all binary constructs, privileges one of the two terms: common memory is devalued, and with it the written text which is regarded as its product. As Horowitz points out in her critique of Felman and Laub, however, conscious recall must not be under-valued: far from being inaccessible, past experiences are, as she reminds us, 'often bitingly conscious for many survivors' (ibid.: 55). Horowitz criticises Felman and Laub for their neglect of the written text: 'Excluded from the authors' construct, then, are other forms of testimony - memoirs, diaries, fiction, poetry - which exist independently of a reader and at the same time enact their testimony for and with each reader' (ibid.: 56). While Langer does not, in fact, exclude the written text from his theorising, he does perform a certain sleight of hand. Though he sets up oral testimony as more revealing, and more 'truthful' than its mediated written counterpart, Langer's very terminology of deep and common memory originates in a written text, namely, Charlotte Delbo's La mémoire et les jours (Langer 1991: 3-7). ${ }^{7}$ More than this, he acknowledges that deep and common memory can emerge in a written text: 'in her [Delbo's] own narrative, and even more in oral testimonies, the two interact and intersect continually, and the challenge to us as audience is to recognize and interpret those moments' (ibid.: 7). Langer's admission that deep memory may be identified in a written text opens the way for a specific form of textual analysis. Although the problem of expurgation remains - accounts may well have gaps due to the inaccessible nature of some material, but a negative cannot be proven - it may be that the reader can identify incursions of deep memory even in a mediated construct. The accounts, as Chapter 2 reveals, are not necessarily chronological. Sudden shifts in time and place ('plot' interfering with 'story') may prove telling, as may abrupt changes in tense (past to present and vice versa) and pronoun (first to third; unexpected use of the impersonal). Metaphors, humour and irony need not be regarded solely as literary devices to aid communication ('all surviving victims who 
write about their camp experiences must adopt some strategy for providing entry into the reader's imagination' [Langer 1991: 42]); the very attempt to 'normalise' can itself be regarded as a means of expressing trauma.

But a caveat must be sounded. The deportees are not, as Horowitz reminds us when she emphasises the conscious nature of much recalled material, merely victims of a pathology: they must not and should not be set up as analysands to be probed by the therapist reader. Langer picks out Delbo as an exceptional writer who explicitly articulates problems of identity, but as the material above suggests, many of the deportees were aware of, and able to express, such issues. Upsurges of deep memory are, indeed, noted by several. Alcan records the manner in which everyday sights - a factory chimney, a railway carriage - can bring back the past unbidden; the cry of a locomotive, or odour of a dentist's drill 'brings back the smell of burning flesh' $(1980,81)$. Maurice also expresses the urgency of deep memory in the face of the quotidian: 'our past suddenly grabs us by the throat, blurs our vision, and raises up shadows' (1993: 10). Jeannin-Garreau points out that her memory comes to her not in a continuous, linear form, but in flashbacks (1991: 32).

Although deportees do not tend to tease out the epistemological implications relating to their textual products, they are not always, as many theorists implicitly suggest, naïve or unreflective. Examples of the co-existence of parallel selves have already been noted. In some cases this phenomenon is expressed in terms which might have come from Langer's own case studies:

From now on there are two 'selves' within us, the 'self' from before, identical to the 'self' from afterwards, and then another, indefinable, indescribable being, whose responses cannot be communicated. It lives in a sort of subterranean realm, and when it comes to the surface, it immediately comes into conflict with the 'self' of this word, the everyday domestic 'self'.

(Dufournier 1992: 162)

Marmor, for her part, is aware of the possible edulcoration of memory:

I prowl around my memories as if around an old bouquet of roses preserved in their vase longer than expected, as long as they are not touched, for if they were, their magic would crumble. 
On tip-toes I draw close to my bouquet whose sweet scent still hangs in the air, a mysterious trace of a past life, and I no longer see the thorns. Could it be that they were the first to die?

(1990: 238)

Langer, Felman and Laub raise important issues concerning eyewitnesses and their limitations, but the binary constructs of deep and common memory, and oral and written account, give rise to another, misleading binary: that of theory and account, expert and deportee, agent and victim, analysand-author and analyst-reader. As the next section will suggest, the construction of binaries inevitably produces situations of conflict between discourses, and equally inevitably reveals a lack of self-scrutiny on the part of some theorists.

\section{What are the accounts?}

The previous section has provided one possible answer to the question 'what are the accounts?': they are eye-witness testimonies whose claims for authenticity rest on lived experience and their proclaimed nonliterary status. Authorial claims have, however, already been called into some question via, for example, the importance of the audience's role in constituting the witness as such, and theories of trauma and memory types. This section will examine ways in which authorial claims for the status of the accounts may be further challenged by competing discourses, notably that of history.

\section{The testimonial writers' views of history}

The accounts may be regarded, in the first instance, as contributing unproblematically to historical knowledge. In his Preface to Heftler's text, Vidal Naquet states: 'Nadine Heftler adds her contribution to our knowledge of the world of the camps' (1992: vi). He goes on, 'In one crucial respect she even contributes something new, and important. So little was known of the "children's block" ... that some people did not believe it really existed. This exceptional place ... has thus been restored to history' (ibid.: vi, my emphasis).

The recovery of important historical data is also attributed to Birnbaum's account, whose preface affirms: 'The eye-witness account of this event [the selection of 27 April 1944$]^{8}$ is crucially important. That is why it is essential that this testimony be passed on, in the service of History' (1946: unpaginated, my emphasis). Henri Marandin pushes the claim to historical status further when he affirms in his Preface to 
Lorge's text: 'This testimonial account has taken on the status of an bistorical document' (1992: unpaginated, my emphasis). Put simply, the accounts in these cases are seen as contributing to historical knowledge inasmuch as they render up factual information about the camps. Given the sizeable nature of the corpus of accounts and the range of experiences they describe, it seems self-evident these texts are indeed a potential source of valuable historical data. As well as providing extensive detail about daily life in the camps (especially Ravensbrück and Auschwitz-Birkenau), the accounts offer insight into the following little-researched areas (to merely skim the surface of the wealth of available material): a wide range of French prisons in which the deportees were held prior to deportation (Drancy and Fresnes, but also jails in Aix-la-Chapelle, Angers, Angoulême, Besançon, Clermont-Ferrand, Dijon, Lyons, Marseilles, Rennes, Rouen and Tours); many littleknown small camps (including Apteroda, Amstetten, Barth, Behndorf, Grazlitz, Holleischen, Limmer, Malchow, Neustadt, Raguhn, Richeling, Torgau, and Zwodau); the numerous varieties of labour undertaken by the deportees (from shovelling sand, draining marshes and wielding pick-axes to tanning rabbit-skins; potato-peeling to manufacturing shells and gas-masks; unpicking and re-sewing uniforms from the Russian front to working in the camp hospital blocks; felling trees to secretarial duties in the SS offices).

However, although a significant number of accounts include claims stressing their contribution to historical knowledge, a shift in attitude can be identified in many of the later texts, which both criticise, and set themselves in opposition to, historical accounts purporting to describe the period in question. Whereas in early accounts 'truth' was defined primarily if not exclusively in terms of lived experience and in opposition to literary discourse, once the history of the period began to be written, 'truth' was increasingly defined in opposition to historical discourse. History and the testimonial account begin to emerge as potentially competing narratives. Whereas in the 1945 Foreword to Dufournier's La maison des mortes the author expresses her desire merely to recount the facts, her 1992 Foreword points out that when all the witnesses are dead,

journalists and historians, already engaged in the study and interpretation of documents and testimonies, will take over. Even if they are in good faith, their analysis will never amount to more than an objective analysis, a faint outline of ours.

(ibid.: 11-12) 


\section{Textual identities I: eye-witness accounts}

Maurice opens her Les murs éclatés (1990) with a statement which places memory and history on an equal footing: 'People tend to see History as, above all, the work of scholars, but it is also the memory of those who lived through events' (ibid.: 10). Three years later a more conflictual position is being articulated: 'Besides, who can legitimately speak of this era if not the witnesses themselves?' (1993: 49). Serge Klarsfeld, who prefaces Touboul's Le plus long des chemins (1997), states that Touboul has succeeded in revealing the true nature of Auschwitz 'something which no history book could ever do' (ibid.: 11).

The reason for such shifts in emphasis is clear: history, it is felt, has failed to communicate. Even in cases where facts are ostensibly known by the public, they are not truly grasped, not absorbed into individual consciousnesses. Geneviève de Gaulle-Anthonioz's Preface to AylmerRoubenne insists that the latter's account should be read because it is 'essential to the comprehension of history' (1996: 13). AylmerRoubenne herself compares her memories to what she perceives as stark historical data: 'Since then I've read the words: "On 23 April 1945, eight hundred women left in Swedish coaches." This perfunctory summary fails to convey the reality of those hours' (ibid.: 104).

The importance of communication and the perception that historical discourse has failed in this task are best captured in a single word which recurs throughout the later accounts: 'transmettre' ('to transmit' or 'pass on'). Crémieux typically raises the question of what knowing about a given historical period might actually entail, asking how one might successfully transmit knowledge and information to a later generation. Differentiating between informing and transmitting/passing on, she articulates the nature of the problem thus:

and that's when the problem of how to transmit such an experience arises. If you do not want it to remain frozen like a stone in a garden of remembrance, like a monument to the dead in a public square, you have to accept that others integrate it into their personal history, that it be fruitful for them. You must accept the difference of the other.

(1999: 106)

Like many of the deportees writing towards the end of the century, Crémieux emphasises three key areas: the need to bridge the gap between past and present, and thus the importance of relevance (to a present generation); the role of the 'other'; and the opening up of an ethical future (captured in Crémieux's notion of 'fruitfulness'). Crémieux highlights the crucial difference between being intellectu- 
ally aware of the facts and truly interiorising that which others have lived through. Representations run the risk of screening reality. Crémieux's own aim - shared by many deportees - is to avoid a repetition of such a masking process. Deportee accounts must seek to transmit the reality of events, to promote an all-important 'realisation' in both senses of the word.

This desire to transmit is echoed in Hartman's analysis of testimonies, which, he states, should not be seen merely as static products, but as humanising and transactive processes (1996: 155). Like Crémieux, Hartman points to a dangerous trend of 'derealisation', a weakening sense of reality, the presence of 'screens' creating distancing effects (1993: 240-1). History, in the eyes of many deportees, has proved to be just such a 'screen', the stark objectivity of the discourse serving merely to evacuate the reality of lived experience, and thus to preclude any contact between author and reader, any communication from one subjectivity to another. As Robert Eaglestone, paraphrasing Levinas, puts it, 'History misses the pain', and the only solution is to reintroduce the subjective experience which is best captured by living memory. Representations of the Holocaust, according to Levinas, must be open to interruption or disagreement; there must be an ongoing dialogue between witness and audience (Eaglestone 2000: 103).

The conflict of interests which emerges in many of the later testimonial accounts is encapsulated in the publishing history of Toulouse-Lautrec's La Victoire en pleurant. Initially, the account was rejected for publication on the grounds that it was not literary enough ('this striking document is not a "book"', claimed Roger du Gard; 'It is not literary in form' echoed Camus, 1967: 8-9). While it would be of little interest to the reading public of the time, according to du Gard, it would doubtless be seized upon by 'future historians' (ibid.: 8). Not so. Whereas deportee accounts were indeed deemed to have a documentary status in the immediate post-war years, by the end of the century, this attitude had changed: 'Nowadays ... testimonial accounts are no longer regarded in terms of contributions to knowledge: time has passed, and historians mistrust fading memories of the past' (Wieviorka 1992: 162-3).

\section{The historians' views of the testimonial writers}

If those deportees writing especially in the 1980s and 1990s increasingly express their dissatisfaction with history, contemporary historians equally distrust the 'memory writers'. The 1990s saw the publication in France of three texts which focus on the role and status 


\section{Textual identities I: eye-witness accounts}

of the witness in the contemporary era: Wieviorka's L'Ère du témoin (1998), Rousso and Conan's Vichy: un passé qui ne passe pas (1994; 1996), and Todorov's Les abus de la mémoire (1998). Although these texts differ in scope and emphasis, all three suggest that memory has become a new social imperative. Wieviorka asserts that we have entered 'the era of the witness', while Todorov states: 'at the close of this millennium Europeans, and especially the French, are obsessed by a new cult - the cult of memory' (1998: 51). All three, with various modulations, perceive an antagonistic relationship between witnesses and historians, summed up by Wieviorka as 'a struggle for power which can be found at the heart of current debates on the writing of contemporary history, but also in other spheres, wherever personal discourse enters into conflict with scholarly discourse' (1998: 165).

Wieviorka's main objection to what she perceives as the ineluctable rise of the witness is the latter's participation in an on-going 'revolution in historiography' whose instigators seek to substitute testimonial writings for 'History' (ibid.: 150). For Wieviorka, this brave new world threatens to displace the key tools of the historian: analysis and synthesis. A collection of individual testimonies (whether oral or written), may chart the vicissitudes of individual memory, but it is not 'history' (ibid.: 146). Indeed, Wieviorka wonders if 'this reluctance to think in general or collective terms, is not in fact the very negation of history' (ibid.: 123).

A number of observations can be made in relation to Wieviorka's stance as it applies (or does not apply) to the corpus of deportee texts in question in this study. First, with respect to her vision of a power struggle between witness and historian, a distinction must be clearly drawn between the aims and intentions of the deportee writers themselves, and those who might seek to foreground or indeed instrumentalise their testimonies. Those deportees who object to the discourse of history do not necessarily claim to be 'doing history' themselves - such a claim is usually made (if at all) by those who wrote before the history of the period had been written - and if they set their accounts in opposition to history, it is because, and to the extent that, they believe history has failed in one key area: that of communication to a present generation ('transmettre').

Wieviorka's depiction and evaluation of testimony rest on a binary construct (history/memory), which privileges the first term. For her, there is only one 'truth' and that is the historian's. The testimonial account, by contrast, is presented as a construction reflecting present concerns rather than providing factual information about the past: 
Although the historian is confident in his own knowledge, and is perfectly well aware that the witness strays from the truth, he is utterly impotent. He knows that every life story is a construction, but also that this construction-reconstruction is the very framework, the backbone of the witness's present life.

(Wieviorka 1998: 166)

Witness accounts, riddled with factual errors, can tell us only of the era in which they were produced. The historian should thus, according to Wieviorka, read them in a specific manner, seeking not insight into places, events, facts and dates (which are often inaccurate) but rather 'the more subtle, but equally vital truth about an era and an individual experience' (ibid.: 167-8).

Where Wieviorka wishes to protect at all costs the 'truth' about the past, Rousso and Todorov, while recognising the dangers of an anachronistic (present-centred) construction of the past, introduce an important emphasis on ethics and on a future-oriented stance. Rousso's and Conan's text closes with the following statement:

Destroying the taboos that existed was thus necessary and beneficial ... But what about now? Does a duty to memory give people the right to put the war-generation on permanent trial? ... A question all the more pertinent given that for our generation, the obsession with the past, with that particular past, merely serves to obfuscate the demands of the present. Or worse still, to ignore the future.

A similar line is adopted by Todorov, who also warns of the dangers of exploiting memory for the wrong reasons and at the expense of both history, and, significantly, the future. A process of social homogenisation and increasing uniformity has created the need for groups and individuals to reclaim and reinforce their identity, hence the new memory cult, for memory, he suggests, may perform the function of strengthening (or indeed creating) identities (Todorov 1998: 53). In order to combat this trend, Todorov suggests that a distinction should be drawn between recalled events as 'literal' or 'exemplary'. 'Literal' memory is intransitive. The recall of traumatic events serves primarily to establish continuity of identity between past and present selves or groups and to point the finger of blame. Exemplary memory, by contrast, allows the individual or group to conceptualise past events as examples of a broader category and to apply that insight to new 


\section{Textual identities I: eye-witness accounts}

situations involving different agents (ibid.: 30-1). Memory should be used to confront present and future realities: 'Once the past is recovered, we must ask questions such as: how will we use it, and to what end?' (ibid.: 33); 'the past thus becomes constitutive of action in the present' (ibid.: 31). Rousso's and Todorov's ethical imperative is one with which the vast majority of the deportees would surely sympathise. The final section of this chapter will reveal the intention to focus attention on past atrocities in the light of current events in order to prevent a recurrence in the future. The deportees' criticisms of historical accounts centre precisely on the need to engage a present generation for ethical reasons.

To some historians, the answer to the question 'what are the accounts?' might be that they are partial, subjective, and often inaccurate representations of the past, but this is itself a partial, subjective and inaccurate representation. That the accounts contain factual errors and represent a personal, lived experience, is not in question, but to claim that they are utterly devoid of 'factual' information is untenable. Although 'facts' and 'truth' are volatile concepts, historians cannot claim them for their own. Their construction of 'truth' is precisely that - a construction - and one which fails to acknowledge that the limitations of the testimonial writers are also theirs. Wieviorka states: 'The witness who bears a certain experience, be it unique, does not exist in and of himself. He exists only in the context of witnessing in which he is situated' (1998: 111). The same can, of course, be said of the historian. Disciplines themselves evolve (history as written in the 1940s is not history as written during the Cold War), and history is written by and for interested parties, who are as implicated in their project as the testimonial writers are in theirs. The binary construct which seeks to define testimony and history in opposition can and should be called into question, as the work of Dominic LaCapra and postmodern theories of history reveal.

\section{The historians and the testimonial writers: breaking the binary}

LaCapra's work is also informed by the dramatic rise in witness testimonies. As he says, 'witnessing - typically, witnessing based on memory - has emerged as a privileged mode of access to the past and its traumatic occurences' (1998: 11). Rather than repeat a hierarchical binary construct, LaCapra seeks to place history and memory on an equal footing, with each term calling the other into question. Historians must strive to recognise their personal investment in their 
object of study. They may be caught up in transferential relations to their material, may unwittingly adopt certain subject positions (innocent bystander, resister with a marked sympathy for the victim and antipathy for the perpetrator or collaborator) and consequently become implicated in a process of 'acting out'. ${ }^{9}$ Unlike Wieviorka, LaCapra stresses the fact that the historians' claims to objectivity and truth must be questioned. Positivistic claims are regarded by him as manifestations of denial or as defence mechanisms, over-reactions to the possibility of acting out which risk 'prompting a confinement of historiography to self-defeating positivistic protocols that may stimulate a return of the repressed in relatively uncontrolled and uncritical forms' (LaCapra 1994: 65). For LaCapra, objectivity must be redefined to indicate a process of 'working through': 'a defensible mode of objectivity achieved in and through an explicit, theoretically alert resistance to projective or wish-fulfilling tendencies and an attempt to engage critically with the problem of one's relation to the past' (ibid.: 71).

If LaCapra's psychoanalytically informed theory reveals the flaws in the privileging of historical discourse on the basis of 'truth' and 'objectivity', then so too do postmodern theorists such Keith Jenkins. As we have seen, those who seek to reveal the shortcomings of the work of the 'memory writers' often fail to put their own house in order. Jenkins is well aware of the resistance of many historians to postmodern views:

Protected by a continued adherence to common-sense empiricism and realist notions of representation and truth, most historians and certainly most of those who might be termed 'academic' or professional 'proper' historians - have been resistant to that postmodernism which has affected so many of their colleagues in adjacent fields.

Although a lengthy discussion of postmodern views of history cannot be attempted here, ${ }^{10}$ even a very brief outline of key issues reveals the manner in which the historians' (or some historians') position can be called into question. While not seeking to deny the ontological reality of the past, Jenkins and others like him insist upon the epistemological issues which lie at the heart of the historical enterprise. What Jenkins refers to as 'old "certaintist" modernisms' such as 'objectivity, disinterestedness, the facts, unbiasedness, Truth' should be replaced by 'readings, positionings, reality effects, truth effects' (Jenkins 1995: 7). Facts, we are reminded, do not speak for themselves: they are both selected and arranged in a specific social, political, and ideological 


\section{Textual identities I: eye-witness accounts}

context. They are also presented in a narrative which rests on certain paradigmatic forms, and which has a temporal frame (the very beginnings and endings of narratives reveal them as 'false', as constructs overlaid on reality). Truth must be redefined: it is not 'out there'; a statement becomes 'true' to the extent that someone has the power to make it true (Jenkins 1991: 31).

To accept the postmodern view of historical discourse is to render untenable the binary construct which would define testimonial texts as the 'other' of history, a binary which rests on the premise that only history has a claim to truth, objectivity, and access to 'the facts of the past'. There is a need (on both sides) to avoid the extremes born of binary constructs. The accounts cannot be dismissed as merely symptomatic of present concerns or attempts to (re)construct identities. Objectivity and subjectivity are the sole preserve of neither historical nor testimonial discourse. What is said about history, of course, applies equally to testimonial accounts: they too are situated narrative constructs produced by ideologically positioned writers. It would, indeed, be true to say that most of the deportees fail to grasp or articulate the epistemological issues at stake in their work, but to criticise their realist stance would be unduly harsh. These are not, after all, professionals who might be expected to know better, and many were writing in a resolutely modernist era. Their authorial position has already been challenged in this study, and it is precisely the function of the following chapters to examine further the constructed ideological nature of their work. Before moving on to this analysis, however, one further area must be discussed, and that is negationism or Holocaust denial, a phenomenon which has been explicitly linked by some commentators to postmodern epistemology.

\section{Negationism}

Although Holocaust denial is an international industry, France has produced more than its fair share of perpetrators, including Paul Rassinier, Robert Faurisson, Louis Darquier de Pellepoix, Jean-Marie Le Pen and Henri Roques. ${ }^{11}$ These negationists, typically, do not tend to invoke postmodern concepts to reinforce their claims. However, as Saul Friedlander points out, we cannot ignore 'the unavoidable link between the ethical and the epistemological dimensions' of the postmodernist position (1997: 391). If there is no such thing as a 'fact', or the 'truth', if both testimonial and historical discourses are ideological narrative constructs, then how can claims about the past, whether they be made by survivors or historians, be defended, and how are we to 
judge the construction of an alternative narrative which would seek to deny the reality of past events?

Several lines of approach have been adopted in an attempt to answer such questions. First, one can maintain a realist position, or at least seek to recuperate some level of epistemic certainty. Deborah Lipstadt, for example, acknowledges the necessity and inevitability of interpretation of past events, and recognises that ' $[b] y$ its very nature the business of interpretation cannot be purely objective'. She goes on, however, to insist upon the existence of a bedrock of factual data: 'But it [interpretation] is built on a certain body of irrefutable evidence: Slavery happened; so did the Black Plague and the Holocaust' (Lipstadt 1993: 21). Omer Bartov, for his part, suggests that we must perhaps simply discard or modify relativist theory in the face of the Holocaust (Bartov 1993: 114). Historical relativism, for Bartov, as an exercise in cynicism, lacks commitment to the truth and to morality, and as such threatens to cast doubt on the very status of the historian: 'If historians, as intellectuals, concede their moral neutrality, then they will finally concede their intellectual, political and moral irrelevance' (ibid.: 114-15).

Others reject what they regard as a radical epistemic position, and the moral and historical scepticism that goes with it, while acknowledging the difficulties in maintaining such a stance. Berel Lang takes as his starting-point the statement: 'On January 20th, 1942, Nazi officials at Wannsee formulated a protocol for the "Final Solution of the Jewish Question"' (1997: 431). Like Lipstadt, Lang recognises that certain aspects of such a statement are open to interpretation: one can raise questions about the status of the officials concerned, or ask whether the Final Solution had, in fact, already been formulated prior to Wannsee. Lang insists, however, that a degree of historical realism must be maintained, if only at the level of the chronicle (who did what when): ${ }^{12}$ 'if representation or interpretation is representation or interpretation of some "thing", what is the ontological status of whatever the representation or interpretation is of?' (ibid.: 430).

Lang is well aware that his position can be (indeed has been) challenged; that it can be suggested that even items of chronicle are ontologically and epistemologically dependent on a pre-existing narrative. Those who accept this position, says Lang, must also accept that a statement claiming that the Wannsee conference did not occur becomes as valid as one claiming the opposite, and that, furthermore, there can be no metanarrative which would permit us to judge between the two. Lang's only answer to this is to invoke both 'common sense' and an ethical stance. If they deny the status of the chronicle, then historians 


\section{Textual identities I: eye-witness accounts}

must accept that it is a matter of their will and imagination - and, perhaps more crucially, their responsibility - whether the Wannsee conference (or by extension any other past event) took place, and this position, Lang suggests, is unlikely to find favour: 'Most people (including, I would guess, the symposiasts themselves) would be reluctant to concede that whether or not they existed five minutes ago depends entirely on what historians (singly or collectively) say about them' (ibid.: 432).

If Lang ultimately refuses to embrace a radical epistemic position, others are more willing to do so, and offer alternative solutions to the problem of negationism. Patrick Finney begins by going over similar ground, suggesting that to regard historical relativism as an uncritical acceptance of all interpretations is little more than a caricature (1998: 361). In practice, Finney points out, 'most relativists have accepted or taken for granted - that there is some sort of bedrock on which (any number of competing) interpretations are constructed.' Epistemological issues should not be conflated with ontological ones: as a discipline and discourse, says Finney, history has the commonsense foundation of a belief in existence of a real past (ibid.: 363). From this, Finney moves to the concept of the interpretive community: 'Relativists and empiricists can agree that the rules and conventions of the interpretive community of historians are one of the factors governing the acceptability of histories' (ibid.: 364). One solution to the problem of negationism arises from this position: the deniers can simply be barred from the community of historians.

Finney, however, is aware of the limitations of this position. The deniers may be excluded from the community of historians, but this will not stop them from disseminating their lies to the general public, who will remain blithely unaware of their exclusion from the academy. Here Finney moves to what seems to be a potentially useful position, namely to use the very relativist discourse of postmodernism to undermine the claims of the negationists by revealing the latter as ideological/political constructivists: ${ }^{13}$

Yet it is also because denial is an ideological enterprise with identifiable (if not always explicit) political goals, which thus offers excellent evidence of the truth of the post-structuralist contention that representations of the past - whether legitimate interpretations or inadmissible lies ...- are always interested knowledge.

(ibid.: 365) 
Rather than seek to engage with a group of people whose 'rules' about what counts as knowledge excludes them from the community of historians (and indeed, I would add, from the community of most lay people), and rather than focus on particular interpretations of the past, attention can fruitfully be directed to the ideological underpinnings of those interpretations.

\section{The fact of the matter: errors, lies, corroboration}

Given that negationists are quick to seize upon errors and inaccuracies in witness accounts, it is crucial that a distinction be drawn here between such unintentional flaws and attempts to lie on the part of testimonial writers. ${ }^{14}$ As Dulong points out, false testimonies threaten the whole institution of witnessing (1998: 62). Although deliberately falsified testimonies are rare, they receive a disproportionate amount of publicity, as the infamous Wilkomirski affair revealed. ${ }^{15}$ In cases such as the latter, clarity is of paramount importance:

Permanent damage can arise only if the status of this text [Wilkomirski's] remains uncertain, which is what its author wants. That everyone is free to believe or not to believe in the authenticity of reports about the Holocaust is precisely the cynically laid-back position of the modern revisionists, who have taken a lesson from postmodern epistemology.

(Maechler 2000: 135-6)

As the section 'When were the accounts written?' will indicate, the deportees in question here do make factual errors, which they may, given the opportunity, subsequently correct in later editions. Some, furthermore, explicitly raise the issue of memory lapses and disagreements regarding certain events. Inconsistencies and error are the inevitable product of human fallibility; they do not invalidate the status of the accounts, nor do they cast doubt on the integrity of the deportees. One aspect of the accounts which can be stressed here is their self-corroborating nature. A vast body of cross-referenced material is available: who was where when (both deportees and SS personnel); the specific conditions which prevailed in a specific lesser-known camp; events both small and great. One example of cross-referenced accounts of events, and the conclusions that can be drawn from it, may serve to conclude this section.

Deportee Mala Zimetbaum's escape from Auschwitz-Birkenau and her subsequent recapture is widely cross-referenced in the accounts, 


\section{Textual identities I: eye-witness accounts}

and a bedrock of corroborated fact can be differentiated from variations in emphasis and detail. Various sources for this incident can be identified: an account of events by an historian; transcripts from the Eichmann trial; and deportee accounts. Martin Gilbert's The Holocaust informs us that on June 241944 Mala Zimetbaum and Polish deportee Edward Galinski, known as Edek, escaped from Birkenau in SS uniforms, reputedly carrying documentary evidence of gassings. The runaways were recaptured, tortured, and publicly hanged. Zimetbaum slit her wrists before several thousand Jewish women who were forced to watch, punched an SS officer, then uttered her last words: 'I know I am dying, but it doesn't matter. What matters is that you are dying, too, and your gangster Reich with you. Your hours are numbered and pretty soon you'll be paying for your crimes.' Zimetbaum was shot, and while still alive, thrown into the crematorium furnace (Gilbert 1987: 695-7).

During session 70 of the Eichmann Trial, when witness Kagan was asked about the case of Mala Zimetbaum, he affirmed first that there was 'a legend about Mala' and that he was thus unsure as to whether or not she carried documentary evidence with her, though she certainly had the courage and opportunity to do so. Kagan states that Zimetbaum was caught by customs officials, and that her Polish companion was tortured and hanged. Prior to her public hanging, Zimetbaum cut her veins, was mocked by a member of the SS, whom she slapped in the face before uttering her last words (acknowledged by Kagan as potentially legendary): 'I shall die as a heroine, and you will die like a dog.' She was subsequently removed to the camp infirmary, and that evening put on a cart and taken to the crematorium. ${ }^{16}$

Many of the French Jewish deportees' accounts mention the Mala incident, including those of Alcan, Birnbaum, Fénelon, Grinspan, Osbert, Ourisson and Touboul. Although accounts agree on the broad lines of the incident, discrepancies do arise when it comes to recording Mala's final gesture and words, which are reported variously as follows: Mala opened her veins and slapped an official before uttering the words: 'Murderers, you'll soon have to pay', and 'Don't be afraid, the end is near; I know, I've been free. Don't give up. Never forget' (Alcan 1980: 44); she slapped the camp commandant and stated: 'Never again!' (Touboul 1982: 72); she slit her wrists, spat at and slapped Hoess (Lévy-Osbert 1992: 146); she slapped the 'Führer du travail' and opened her veins (Birnbaum 1946: 96); she slapped an SS guard, slit her wrists and cried out: 'Rise up! Rise up! There are thousands of you. Attack them' (Fénelon 1976: 243); she slashed her wrists, was struck by an SS guard whom she struck in return (Ourisson 1947: 26); she 
uttered the final words: 'Stand firm, it will soon be over' (Grinspan and Poirot-Delpech 2002: 98).

There is little doubt, as Michael Pollak notes in his L'Expérience concentrationnaire, that the story of Mala gained legendary status among the deportees, a fact which is recognised by several of the latter (LévyOsbert refers to the 'legend of the camp' and describes Mala as a 'a true martyr, a symbol of courage, self-denial, and sacrifice', 1992: 146; Grinspan states that Mala 'became a mythical figure for us all', Grinspan and Poirot-Delpech 2002: 98). It is also likely, again as Pollak suggests, that such a mythical status had much to do with the presence of a combination of romance (Mala escapes with her lover Edek) and ruse. To claim, however, that we should not look for the truth in this tale but merely to analyse the elements which contributed to its mythical status, is, once again, to overstate the case (Pollak 1990: 213). The accounts differ in their reporting of Mala's final words, but they also agree on the basic elements of the incident: Mala escaped, was recaptured, was due to be publicly hanged, slit her wrists by the scaffold, lashed out in some way against an official, and uttered some words. In the absence of documentary evidence relating to this incident, it is only the accounts of the deportees which have prevented the total effacement from 'history' of a significant act of courage. Details of the 'truth' may be hard to pin down, but witness accounts remain a valuable source of material, notwithstanding the element of subjective input and narrativisation inevitably present in all accounts.

\section{When were the accounts written and published?}

\section{Publication}

In terms of dates of publication, the corpus forms two principal clusters: the immediate post-war years (1945-50) and the late 1980s to the present day. If Jewish-authored accounts are examined separately, a modified publication distribution emerges, with the accounts bunching almost exclusively in the later period. The early grouping confirms Wieviorka's claim that, contrary to popular belief, deportees were anxious to write about their experiences immediately upon their return. (Wieviorka 1992: 169-76). Problems of reception have already been noted. As Wieviorka puts it: 'Publishers are not philanthropists: they want their books to sell ... The absence of a market, of buyers and readers, explains in part why the flood of accounts was stemmed' (ibid.: 169). Given that many deportees actually wrote of their experiences immediately upon their liberation from the camps (see below), it 


\section{Textual identities I: eye-witness accounts}

seems likely that a significant number of accounts may simply not have made it into print until the socio-political climate, and the market conditions, proved more favourable to publication.

The delayed publication of Jewish-authored accounts also substantiates received views that 'Jewish memory' emerged only several decades after the end of the war as a result of a concatenation of socio-political events (ibid.: 337-68). Wieviorka identifies the Eichmann trial of 1961 as a key moment in the emergence of the Jewish witness (Wieviorka 1998: 81). ${ }^{17}$ Rousso points to the Six Day War of 1967 and de Gaulle's 'unfortunate words' (his reference at that time to the Jews as an elitist, confident and domineering race) as another crucial contributor to the raising of Jewish consciousness, but regards 1978 as the primary watershed, a year marked by the Darquier de Pellepoix affair, the controversy surrounding the broadcasting of the telefilm Holocaust, and the Faurisson negationism scandal. ${ }^{18}$ The high-profile indictment of Vichy bureaucrats (Leguay, Bousquet, Touvier, Papon) in the following years kept Jewish memory to the fore.

The trial of Klaus Barbie in 1987 not only kept the genocide firmly in the public consciousness, it also marked, as Rousso notes, a turningpoint with respect to perceptions of the Resistance (1990: 245). In the course of the trial Barbie's principal defence lawyer sought to undermine the credentials of the Resistance by claiming that it was 'riddled with informers who were responsible for the fate of Jean Moulin' (Gildea 1996: 81-2). Controversy surrounding this and other Resistance heroes continued when Moulin was accused having been a Soviet agent, and Raymond Aubrac an agent of Klaus Barbie. The questioning of Mitterrand's Resistance credentials triggered by the publication of Pierre Péan's Une jeunesse française in 1994 further contributed to the troubled climate. ${ }^{19}$ It seems likely that these socalled revisionist views may well have prompted many deportees who had taken part in Resistance activities to tell their tale. Certainly the rise of Holocaust deniers prompted many Jewish deportees to seek to set the record straight. Finally, the ageing population of Jewish and non-Jewish deportees alike, coupled with the perceived ignorance of a new generation vis-à-vis the war years, inevitably contributed further to the clumping of publications in the later period.

These publication clusters, however, mask the significant fact that the writing of the accounts potentially spanned three different periods: the taking of notes (in some cases in the camps), the production of the first manuscript, and the actual publication. 


\section{Writing in the camps}

The sheer number of accounts which mention the taking of notes by deportees while in the camps belies what is perhaps a common perception that this was an impossible task, although the authors in some cases (by no means all) do point out both the practical difficulties involved in obtaining the necessary materials, and the risks incurred. Not surprisingly, writing in the camps was much less common among the Jewish deportees held in Auschwitz. Nonetheless, a small number did indeed find the opportunity to keep a record. ${ }^{20}$ Marmor, for instance, points out that the Prologue to her account Le Piano rouge (1990) was based on notes taken when she worked in the SS offices in Auschwitz. Fénelon, in her Sursis pour l'orchestre (1976), also mentions the taking of notes on several occasions. Both of these deportees, it should be acknowledged, were in relatively 'privileged' positions (Fénelon was a member of the Auschwitz-Birkenau deportee orchestra).

One exceptional case deserves special mention here, that of Ana Novac, who at the age of only fourteen wrote a first version of what was to become Les beaux jours de ma jeunesse while in Auschwitz and Plaszow, thereby producing, according to the 1996 Folio edition's cover blurb, 'the only journal ever to come out of a Nazi death-camp'. Novac apparently remained somewhat underwhelmed by the scale of her achievement:

If my journal really is the only one ever to come out of the camps - and so I gather - I'd be amazed! Contrary to popular belief it was just a matter of will ... The key thing was to find paper, a pencil... That's how I came to be the sort of person who rummages through rubbish and tears down old notices.

(1996: 10-11)

The journal was smuggled out and delivered into the hands of Novac's concierge in 1944 by a German criminal who was released from the camp. This original version, written in Hungarian, remained untouched until the early 1960s, at which time it was revisited by Novac but rejected for publication by the Hungarian authorities. When Novac left Hungary in 1963 she took her typescript with her, and subsequently produced a French version under the title J'avais quatorze ans à Auschwitz with Julliard in 1968. Novac reread her text in the 1990s and decided to rework the French, which she felt lacked the verve of the Hungarian original, from her original notes. The final version was published by Balland in 1996. 


\section{Textual identities I: eye-witness accounts}

Taking notes while in the camps was more widespread among nonJewish deportees. Some authors are explicit about their activity, for example, Chombart de Lauwe, who states that the notes she took in 1945 lend her text 'the voice of the young girl ... in prisons and Nazi camps' (1998: 11). Lesèvre, by contrast, refers almost casually to her note-taking mid-way through her account: 'It was the terrible bombing of Dresden (according to my tiny logbook it was 13 February, 1945)' (1987: 118). Maurel is rather more informative on the procurement of writing materials, explaining that she received a supply of notebooks made from forms printed on one side only from a fellow-deportee working in a nearby factory (1957: 103), and that she also kept a rudimentary journal on the back pages of small poetry notebook (ibid.: 122). It is uncommon for authors to refer to early notes in any detail (how many, indeed, do not even mention the fact that such notes were taken in the camps?), but of considerable interest when they do. Friang refers to notes taken in Zwodau just prior to her transportation to another camp: "The dormitories are regularly searched, so I keep my toothbrush, rescued from Ravensbrück, my piece of comb, and my precious notes hidden in my hem' (1997: 160). While writing her account in 1967, Friang used these early notes to reinforce what has become an imperilled sense of personal identity:

What do I have in common with that young twenty-year-old girl who struggled against death every minute of the day in a concentration camp. She certainly gave birth to me, but I am not her ... And yet, all I have to do is open the manuscript and reread those brief lines, inscribed, transcribed and re-transcribed in jail, in the camps ... and I'm in touch once again with the universe of the dead.

(ibid.: 169)

A slightly different perspective is afforded by Crémieux, whose notes were taken in 1946. Citing these at some length, "rough and ready", just as I found them' (1999: 27), Crémieux analyses her own early records: her writing then was, she points out, 'sometimes illegible, as if I wanted to hide what I was writing from myself' (ibid.: 27). In this case, the notes were considerably less perfunctory than those taken in situ, as the example of her arrival in Ravensbrück suggest: 
'You'll soon be there, there's the lake', a soldier tells us. And we think that maybe we'll be allowed to swim in it.

Overall, everything is looking good, magnificent sunshine, pleasant surroundings: after all, as long as it's brief, a trip to Germany is an experience.

(ibid.: 29)

The irony of these naïve first impressions was doubtless not lost on the author.

\section{From first text to published text}

Whether basing their manuscripts partly on notes taken in the camps, or writing their account from scratch, many authors had certainly completed a version long before the text was finally published. Reasons for the delay in publication doubtless varied, but the difficulty in finding a publisher was certainly one, as the case of Toulouse-Lautrec reveals. Written in 1946, her La Victoire en pleurant was, as we have seen, deemed to be unsuitable for publication on literary grounds. After winning the Grand Prix Vérité awarded subsequent to a competition organised by Le Parisien Libéré in 1957, Toulouse-Lautrec tried and failed once more to secure a publisher, finally paying for a private printrun in 1966 in order to guarantee that the account find its way onto the shelves of the Bibliothèque nationale. ${ }^{21} \mathrm{~A}$ commercial outlet was finally found in 1979. Other authors did not originally intend their manuscripts to be published. Maous, Coma: Auschwitz no. A5553 (1996), finally went to print in an attempt to go some way towards mitigating negationist claims. In his Preface to the text Vidal-Naquet refers to a 'manuscript written half a century ago and presented to the reader virtually untouched' (ibid.: 11-12).

Vidal-Naquet's claim that next to no alterations were made to Maous's text raises an important question: to what extent were texts modified when they passed from manuscript to published text? Authors vary in the degree of information imparted to their readers. Picard, Des Ténèbres à la lumière (1995), mentions only in passing that she based her text on a version written five months or so after liberation (ibid.: 117), and says nothing about possible alterations. In her Sans fleurs ni couronnes (1982), dated September 1945, Elina states in her Foreword that her text has been re-published (the first edition, with a very limited print-run, was exhausted) 'without any changes being made'. Abadi, Terre de détresse: Birkenau, Bergen-Belsen (1995), notes that she wrote her account immediately after liberation, then 
reread and recopied her old notebooks 'with utter respect', making only minor changes: 'I did, in spite of everything, correct, remove or add a few lines here and there, so that the whole thing was more coherent' (ibid.: 9-10). As is the case with a number of texts initially written immediately after the war, many of which span the period 'arrest to liberation', Abadi expands the chronological span of her account, adding material relating to her arrest and the post-liberation period.

\section{Re-published texts and the question of amendments}

It is clear from what precedes that the finished product that is a published account may well comprise many temporal layers of inscription, and without access to original manuscript versions or to notes taken in the camps, the extent and nature of potential modifications may never be known. Amendments can, however, be traced in the particular case of those accounts which were re-published, a small sample of which will be considered now.

Changes to such re-published texts may take various forms. Touboul's Un relais d'étoiles (1982) was reissued under the new and more immediately informative title Le plus long des chemins: de Marseilles à Auschwitz (1997). Maurice's N.N. (SPER, 1946) was re-issued on two occasions by a different publisher nearly fifty years later (Encre marine, 1991 and 1995); Dufournier's La Maison des mortes (Hachette, 1945) moved to the Julliard publishing house in 1992. Alterations and additions are most commonly located in the paratext. While Touboul prefaced her original 1982 edition, the later 1997 preface is written by the high-profile Serge Klarsfeld. The Preface of Maurice's N.N. of 1946, written by Jean Nocher, closes on a note bemoaning the fact that France is losing the peace; the later editions are prefaced by Marcel Conche, who emphasises youth and the need to learn from history for an ethical future. Maurice's later editions also see a change

from the use of footnotes to the inclusion of a glossary, the removal of all appendices, the majority of poems included in the first edition, and all of Jacqueline Richet's sketches. Both editions of Dufournier's $\mathrm{La}$ Maison des mortes are prefaced by Maurice Schumann, the first 1945 Hachette edition's Preface describing the transcendent beauty of the female deportees whose suffering is compared to that of Christ (in somewhat florid terms). Schumann moderates his language in the Preface of the 1992 edition, stressing the unpleasant experience of the author's return to a 'normal life'. Dufournier's own Foreword of 1945 is preserved in the later edition, but a new one is added (ibid.: 11-12), as 
is an entire chapter, 'Later... Reflections' (ibid.: 156-74), written in the present tense (unlike the rest of the text), and again presenting an extremely bleak view of the return of the deportees and the chasm that separated them from those left behind.

In some cases factual inaccuracies are corrected: Touboul's 'one hundred thousand deported from France' (1982: 148) is altered to 'seventy-six thousand deported from France' (1997: 193-4). In her Ravensbrück: l'enfer des femmes Saint-Clair changes the term 'vitaminose' the word does not exist - (1945: 38) to 'avitaminose' (vitamindeficiency, 1966: 45); 'Volksteutsch' (1945: 97) becomes 'Volksdeutsch' (1966: 98); 'Zauer' (1945: 133) is changed to 'Fritz Suhren' (1966: 133). Other alterations may be motivated by something other than a desire for factual accuracy. Maurice, for instance, alters 'Germans' to 'Nazis' on two occasions: ${ }^{22}$ while we are informed in the 1946 edition of N.N. that some of the 'Bibelforscher' (Jehovah's Witnesses) 'had to look after the Germans' children' (ibid.: 49), this is altered to 'Nazis' children' (1995: 37); a 'blockowa' (deportee in charge of order in the Block) seen making love with a 'German soldier' in the first version (1946: 74) subsequently does so with a 'Nazi soldier' (1995: 76). The later edition of N.N. also sees the extirpation of an entire section entitled 'My friend Bluette's impressions during her visit to block 15' (ibid.: 37-8), in which Bluette recounts a visit to the allFrench block and the shock she experiences when witnessing the polite 'civilised' atmosphere in comparison with Block 23, described - in somewhat racist terms - in the first edition as filled with an 'oriental rabble' living in a 'subhuman' 'state of resigned filth' (1946: 38).

Material may be intensified in tone. Saint-Clair alters a reference to 'Kraut tortures' (1945: 52) to 'diabolical tortures devised by the sadistic Krauts' (1966: 57). Touboul's alterations to her references to the Auschwitz gas chambers are minor: 'where the deadly, asphyxiating gas did its job' (1982: 37), becomes 'where the deadly gas did its job, asphyxiating the new arrivals' (1997: 49), the present participle heightening the sense of agency and immediacy. Later in the text(s), a single phrase intensifies the horror as 'the prisoners hauled themselves into the trucks and soon after entered the gas chambers' (1982: 91) becomes 'Soon after they entered the gas chambers with their children' (1997: 119). The arrival and gassing of the Hungarian Jews are described in the past historic in the earlier text (1982: 97), but in the more immediate present in the later version (1997: 127). Material may also be 'toned down'. When Touboul describes the in-fighting among deportees in the 1982 edition, the use of the first-person plural pronoun includes the French: 


\section{Textual identities I: eye-witness accounts}

The Nazis' deliberate policy of assembling all these women from different countries in a single block, where they lived crammed together in a state of over-crowding that soon became unbearable, inevitably gave rise to hatred among us, though we faced the same fate, were destined for the same torture and the same death.

(1982: 48-9)

In the later version 'we' has become 'they', the pronominal shift serving to exclude the French from a negative representation of infighting. A reference to cannibalism is similarly edulcorated: 'the prisoner ... did not hesitate to open up a fellow-deportee's body, remove the liver and heart and devour them' (1982: 122), becomes 'the prisoner who, in order to save her life, did not hesitate to remove the liver and heart from a fellow-deportee's body' (1997: 157).

In some cases alterations are quite substantial. In the later edition of her Ravensbrück: l'enfer des femmes Saint-Clair intercalates new material explaining exactly how she was able to keep notes while in the camp, thereby possibly aiming to counter potential scepticism. Later in the text five new paragraphs recount how the author stuffed her spectacles case with her notes, was nearly caught in the act, and subsequently hid her papers in the rafters (1966: 128). The greatest alteration, however, comes with the changes to an entry dated 23 December [1944]. Where the original version has only three lines relating to this date ('The thermometer read minus 14 this morning... We're freezing. We've found out that our letters will not be sent to Switzerland: it's a sham...', 1945: 138), the later edition is expanded by several pages which chart the making of a Christmas Nativity scene by a French deportee (1966: 139-40), as well as Saint-Clair's own ambivalent feelings in the face of such normality, which serves to bring back painful memories of the past (ibid.: 140-1). Entries for 24 December remain unchanged from one version to the next, but the entry for Christmas Day is completely metamorphosed: the later version introduces a much more upbeat tone coupled with a eulogising use of the second-person pronoun addressed directly to Saint-Clair's fellow deportees, praising the spirit, humanity and courage of the French.

\section{Why were the accounts written?}

As will have become apparent, to examine when the accounts were written is already, inevitably, to touch on the question 'why?': in many cases the deportees were responding at least in part to specific temporally circumscribed socio-political circumstances, such as the rise of 
negationism. Motives for writing, however, also include those which cut across the whole temporal range of publications, for instance, a desire to inform the public, or a perceived obligation to the dead. Writing may serve the self (the shoring up of personal identity) or the other (commemoration, the fulfilment of a promise made in the camps). Finally, motives may be inferred by readers and critics, rather than explicitly articulated by the authors themselves. These various categories are by no means mutually exclusive: a desire to write to combat negationism may be explicitly motivated by a duty to the dead, but may equally result from a need to validate the author's own lived experience and identity.

\section{Information}

As Wieviorka observes, 'in the immediate post-war years, testimonial accounts were seen primarily as a contribution to knowledge' (1992: 162). But an aspiration to inform the general public was not exclusive to those writing in the late 1940s. The perceived necessity to acquaint a given readership with the facts of deportation remained for those writing in later years and indeed decades, either because the French public had apparently forgotten all too soon, or because members of a new generation revealed their ignorance of the period. In later texts a focus on youth is a common topos. Often, it is children or grandchildren who prompt those who have perhaps kept silent for years to write: 'I have to leave a testimony, my children have to know what happened to my family and what happened to me' (Schapira 1994: 35). A deplorable lack of knowledge among the young is frequently noted. Grinspan expresses her horror when schoolchildren enquire of her time in Auschwitz: 'Were you granted leave?' (Grinspan and PoirotDelpech 2002: 214). Lasnet de Lanty observes that 'a lot of young people still do not know exactly what happened' and cites children asking 'what does "concentration camp" mean?' (1965: 260). Lagrange, however, is encouraged by the apparently inquisitive nature of the young:

How could I not fight in the name of Truth when I see that need for knowledge gleaming in the eyes of the young people listening to me, who ask me to visit each year, who find no answers to their questions in their schoolbooks, even though those books have been improved? I believe that nothing will replace the eye-witness account.

$$
(1997: 195)^{23}
$$




\section{Textual identities I: eye-witness accounts}

The importance of 'transmission' in the context of the failings of historical discourse has already been noted above.

\section{Admonition}

Paratextual statements in accounts of the late 1940s and the 1950s often made by those prefacing the accounts rather than by the authors themselves - may articulate a desire to warn the general public of ostensible threats. Anti-German sentiments are not uncommon, and are often expressed with some virulence. Deportee Camille Delétang, prefacing Busson's account, urges readers to fight the tendency to forget: 'Otherwise tomorrow, a powerful reconstructed Germany, bloated with hate and vengeance, will bring death and destruction to the whole world and, this time, will subjugate every citizen of France and utterly annihilate them' (1946: 11). General Audibert, prefacing Wilborts's Pour la France (1946) does not mince his words when contemplating the threat of 'la Bochie': 'It is because this wild beast is so terrible that we must realise what it is capable of'; 'this [the atrocities committed] must never be forgotten, for if we are not vigilant, it will happen again' (ibid.: 10). Warnings may be more tempered. Marette links the duty to remember to fears of a recurrence of similar events, but articulates her warning rather more even-handedly: 'Germany and France have the same interest in remembering a past festering in blood, because that past is a warning for the future' (1954: 11).

Cautionary constatations of the 1950s are often linked to on-going diplomacy relating to the rearmament of Germany, the latter's joining of NATO and the establishment of a common European market. ${ }^{24} \mathrm{~A}$ footnote written by Bernard Lavergne in Lahaye's Visions d'un camp de concentration captures the general tenor of such comments:

At a time when a significant number of French citizens, yielding to the spirit of generosity, indeed to the instinct for utopian fantasizing which are two of our national traits, envisage an era of peace and idyllic concord among nations created under the auspices of a United Europe, it is advisable to readdress the facts ... The facts described in the following pages date back not to a previous century but to merely eight years ago. In an era when so many utopian projects of a United Europe are drifting through certain minds, the reading of these accounts may thus inspire a salutary pause for thought. 
Anti-German sentiments, perhaps unsurprisingly, tend to have more than an admonitory function. They also highlight the point made by Dulong that the witness necessarily calls his or her audience to judge: 'the validation of the facts is only confirmed by the judgment which follows' (1998: 137). While it remains implicit in some cases, this notion of a call to judgment emerges clearly in others. When Lasnet de Lanty states that 'I was duty bound to add my testimony to the already substantial dossier of Nazi crimes' (1965: 260), her role as 'prosecution witness' is clear.

Judgment and the concomittant desire for justice are also identified by Ricœur as a key part of the testimonial endeavour:

It is justice which, by extracting the exemplary value of traumatic memories, restores to memory the status of a project; and it is that same project founded in the will to justice which conjugates the duty to remember in the future and in the imperative.

(2000: 107)

As we have seen, in expressing anxieties (or indeed outright hostility) in the face of the 'rise of the witness', critics such as Todorov have singled out the notion of exemplarity as key. Criticisms of witnesses on the grounds that the latter fail to draw widely applicable lessons from their experiences and thereby do not engage in a future-oriented, ethical project, are, however, misplaced in the case of many of the writers of deportee accounts: experience of the camps has, in fact, honed the desire for justice - at any time, and in any circumstances among many writers. Lesèvre typifies a willingness to learn from a singular experience: 'We can no longer tolerate injustice. Or the misery of others. Respect for the human individual? Also essential. Racial conflicts, "colonial" conflicts, all take us back to Ravensbrück' (1987: 156). Following a similar path, Chombart de Lauwe concludes her Toute une vie de résistante (1998) with the exemplary image of a lone student facing a tank in Tiananmen Square (ibid.: 196), while Maurice's Résurgences (1993) ends with a reflection on the ethnic cleansing taking place in Bosnia. Davidovici, finally, who insists that life after the Shoah should be premised on the concept that 'suffering does not confer privileged status' (1998: 77), states that the duty of deportees is to be 'seismographs who detect danger before other people, who see the potential warning signs which might herald a second tragedy' (ibid.: 83). 
Textual identities I: eye-witness accounts

\section{Negation: denying the deniers}

If a desire for justice is a prime incentive for putting pen to paper, then it comes as no surprise that many writers are prompted to write by the negationist claims which emerged in the late 1970s. As might be expected, it is above all Jewish writers who write in response to the deniers. Marmor typically breaks a silence of forty-five years in response to the 'despicable words of those who seek to deny this awful truth in order to spread hatred and contempt for human life' (1990: 103). Great faith is placed in the eye-witness, regarded by many deportee writers as the last, and most powerful, line of defence against those who would deny the reality of the past: "They [those who seek to "falsify history"] will be helpless in the face of this reality vouched for by the thousands of survivor testimonies across the whole of Europe' (Touboul 1982: 203); 'Sorry, dear falsifiers of history. We are still alive to bear witness' (Lévy-Osbert 1992: 130). Picard makes a similar point: for her 'the weight of personal testimony' represents an undeniable force

which no historian or pseudo-historian tempted by the evil impulse to rewrite the History of Nazism, to deny the holocaust, the Final Solution, the gas chambers and other diabolical inventions, which, I repeat, no historian (or pseudo-historian) will ever be able to call into doubt without being taken for a liar, a falsifier, and a manipulator of facts.

(1995: 134)

Writing in response to negationist discourses is not limited to Jewish deportees. Crisimily, for instance, refers to the Darquier de Pellepoix affair (1981: 185). Often, however, non-Jewish deportees reveal a potentially misleading tendency to conflate negationist and so-called revisionist discourses. Maurice, for instance, writes her Les Murs éclatés (1990) prompted partly by the appearance of 'those who ... choose to deny the atrocities of the period, the gas chambers, and to minimise the role played by the French Resistance' (ibid.: 9). Brun similarly objects to both the Holocaust deniers and those who seek to tarnish the memory of the Resistance: 'the proliferation of literature glorifying the former SS is gaining ground, they are even denying Auschwitz, racist violence is everywhere on the increase, monuments to the deportation and the Resistance are being desecrated' (1979: 5). 


\section{Duty to promises made}

To deny the deniers is, in part, to seek to validate the experiences of fellow-deportees, especially those who did not return. The most widely articulated motive for writing is a sense of duty to the dead, the accounts taking on a performative role as the fulfilment of a promise made to 'tell the world'. Duty and justice come together here: 'The duty to remember is the duty to secure justice, through one's memories, for someone other than oneself' (Ricœur 2000: 108). As Saint-Clair states:

Writing what I was to see and live through, shouting the truth as I witnessed it to the world - this became my goal. That goal became a duty when, as I stood by the bedside of dying friends, they had to courage to murmur: 'You'll write about everything we've suffered, won't you?... People must know...' I promised them that I would.

The keeping of the promise cuts across the decades of publication. De Lanty (Sous la schlague) writes in 1965:

What we lived through in the camps and during the march out along German roads was worth the telling, not only because it has value as testimony, but also because these memories do not belong to me alone:

'You will tell of everything that they did to us...'

I have kept my promise.

(ibid.: 262)

Tichauer's sense of duty remains as strong after a forty-year silence: 'We promised them to reveal everything if we returned' (1988: 18), while Touboul expresses guilt at having taken so long to fulfil her promise (1982: 200). Grinspan, referring to her writing as a 'sacred mission', closes her text of 2002 on the last words of a fellow-deportee en route to the hospital where she was to die: "If you return, you'll have to tell them. They won't believe you, but you must tell them." They - in other words, you. Today. Tomorrow' (Grinspan and PoirotDelpech 2002: 235). 


\section{Textual identities I: eye-witness accounts}

\section{Commemoration and incorporation}

The discharging of duty to the dead shades into a commemorative function. Accounts are often charged with apostrophes to individuals or groups of deportees. Roux dedicates her Triangle rouge (1946) to those with whom she suffered and those who died, the first three pages of her account comprising a list of names evoking those inscribed on a war memorial. Vidal Naquet's Preface to Heftler's account states that the author wrote for her parents as one would inscribe words on a tomb for loved ones, a text for those who have no grave' (1992: iv), while Grinspan's text is perceived by her as 'the wreath which, at the end of our visits, we leave on the lake in which the ashes of the crematorium sank. It will be the stone left at gravesides by observant Jews' (Grinspan and Poirot-Delpech 2002: 222).

The commemorative function also highlights the close bond between the dead and the living; the fact that the latter are kept alive only by the survivors: 'according to the Indians, only those who no longer exist in the memory of the living are truly dead' (Lesèvre 1987: 85); 'would erasing their suffering from our memories not amount to killing those who suffered so much all over again' (Hollander-Lafon, Introduction by Roger Ikor, 1977: 8-9). Tichauer's text is a means of keeping her murdered parents alive - 'They can only carry on living through me' (1988: 17). More than this, to forget the dead is in some way to destroy oneself; the boundary between ' $I$ ' and the other is fragile. As Lahaye states:

We know that our liberation will never be complete because we will have left behind us not pitiful corpses but souls which were links in a chain which bound us together, that it was impossible to remove lives from this great pulsating mass of flesh, of blood, and especially of souls, without mutilating our lives forever.

(1983: 67)

The dead are perceived as being incorporated into the living: 'You are still with me, in spite of all the time that has passed' (Mori-Perrin 1992: 161).

\section{Writing for the self}

Attitudes to the past are inevitably difficult and ambivalent: while it is imperative to remember those who died and are kept alive in the memory of survivors, the latter must also bridge the chasm between 
past and present self. As the previous section on trauma suggested, multiple 'selves' co-exist both within the camps and at the time of writing. Writing may consequently serve as a means to integrate the past into the present, to recover a sense of personal integrity. Crémieux expresses the need to 'recover this moment of my life in order to inscribe it ... into the continuity of my personal history' (1999: 10), while Maurice, in response to a young student's suggestion that she might put the past behind her, points out that to do so would be to threaten her own identity: 'Would attempting to erase our struggle not amount to denying ourselves?' (1993: 49).

In some instances it is not so much a case of integrating the past into the present, of establishing continuity after rupture, but rather of recovering a self which pre-dates the traumatic experience. The camps are represented in terms of an affliction which must be overcome. Roux describes her attempt to cure herself of the camps: 'In order to free myself from a terrible, inchoate suffering, I stripped my memories away one by one, like disease-pitted petals' (1946: 226). Strikingly, when deportees articulate a need to dispel or expel the past, the somatisation already noted above returns: 'if we were liberated one day, we felt that we would not recover our integrity, our ability to re-adapt, until we had vomited, spat out the venom in which they had sought to mire us' (Jeannin-Garreau 1991: 37). Maous employs similarly corporeal vocabulary: 'All I wanted was to respond to an urgent physical need, to vomit out memories of an abject time' (1996: 177), while Abadi speaks of writing 'as if to free myself from a testimony which was suffocating me' (1995: 9).

Whether for the self or the other, as a response to the present climate or to past promises, the preceding section is based on motives articulated by the authors of the accounts. It would, of course, be naïve to accept these claims entirely at face value: motives, as has been stated, may be unacknowledged or even unknown to the writers themselves. One of the motives for writing is the need to reinforce identity, whether this is personal, collective or national (or indeed a combination of all of these). Chapters 3-5 are intended to reveal which identities may be involved in the process of representation. Although this chapter has already gone some way towards challenging perceptions of the status of the accounts based on authorial intentionality (that is, the deportee-writers' own claims for their accounts), the following, complementary, chapter goes further. The deportees claim that their work is not 'literary'; they stress the importance of lived experience, but as James Young points out, 'what was evidence for the writer at the moment he wrote is now, after it leaves his hand, only a 
50 Textual identities I: eye-witness accounts

detached and free-floating sign' (1987b: 413). As we shall see, the testimonial account is a mediated text, which, if it is to fulfil the aims of its author, must also fulfil certain conditions at the moment of reception. 


\section{Textual identities II The accounts as textual constructs}

In the previous chapter we saw that the accounts are commonly described as 'entirely devoid of literature', free of all 'literary effects'. But what can such assertions mean when an account thus described opens in medias res with the dramatic line: 'Kratz slowly crossed the deserted, sunny courtyard; as usual, his head was bobbing up and down and he was jingling his keys loudly' (Renault 1948: 19)? The answer lies in part in the fact that 'not literary' equates to 'not fiction'. The 'truth' of the accounts is premised on what was 'seen' and 'lived through' by the author; they are not products of the imagination. This, however, can only be a limited response. As Young points out, an insistence on the absence of the literary and on the importance of the eye-witness are themselves rhetorical moves: there is no such thing as style-less narrative or unmediated fact (1988: 8).

\section{Telling it as it was: truth, artifice and paradox}

'Telling it as it was' poses serious problems to the deportees: how can they communicate a radically alien experience to their readers? The accounts repeatedly stress the failings of language, the difficulties of conveying 'the truth of the matter' to an uninitiated other. Everyday activities, objects and affects take on new meaning in the camps, and authors consequently find themselves engaged in a process of qualification and gloss: 'We had to get up at three thirty in the morning, make our beds, try to splash some water over ourselves (that was called washing) ... and drink a mug of warm water called "coffee"' (Crisimily 1981: 126-7). 'Not a single woman says "I'm cold." What would be the point? The word no longer corresponds to anything; the word we used on earth without a second thought has lost all meaning' (Maous 1996: 124). An epistemological abyss separates the universe of the camps and the world of the reader. Only those who have been there can 


\section{Textual identities II: textual constructs}

ever comprehend: 'Hunger is not something you can describe, for those who have never experienced it, it's just a word' (Aylmer-Roubenne 1996: 47). Authors who begin to describe certain experiences hesitate and lapse into metatextual comment or silence: 'Four days on the train. That's the norm. Those would prove to be the most painful, the cruellest of all (but there are no words!)' (Carliez-Lambert de Loulay 1945: 159). A new universe requires a new language. Writing about their liberation, both Lorge and Maous refer to their difficulties in expression in terms of translation: 'I can't express my joy; it's untranslatable' (Lorge 1992: 28); 'will I try, will I be able to translate what the night we were liberated meant to us?' (Maous 1996: 165-6).

Frustration in the face of the inadequacies of language and the magnitude of the task of communicating is summed up by two authors: 'But what words can express it, what words can describe it, what words can explain? Inexpressible words' (Lévy-Osbert 1992: 159, my emphasis); 'The unimaginable/How do you communicate the unimaginable?' (Mori-Perrin 1992: 85, author's emphasis). These words are also the key to the apparent contradiction of the 'non-literary' account which nevertheless displays a full range of literary and rhetorical traits, for they neatly encapsulate the key trope which governs testimonial literature: that of paradox. Inexpressible words must nonetheless be articulated by the author and the unimaginable imagined by the reader. ${ }^{1}$ How is this to be achieved? Precisely by means of another paradox: in order to persuade the reader that the accounts are true, are 'not-literature', literary devices must be deployed. Very few, if any, of the deportee writers explicitly acknowledge a concept which is articulated with great lucidity by Jorge Semprun:

I began to have doubts about the possibility of writing. Not that the experience was unspeakable. It was unbearable, which is quite another matter ... A matter which does not affect the form of a potential account, but its substance. Not its articulation, but its density. Only those who can make an aesthetic object of their testimony, will attain the necessary substance, the necessary transparent density; only those who make of it a space of creation. Or of recreation. Only the artifice of an account under the full control of its author will succeed in partly conveying the truth of testimony.

(Semprun 1994: 26, my emphases)

To tell it well means in such a way as to be heard. This will not be achieved without some artifice. Sufficient artifice to make it art!

(ibid.: 165) $)^{2}$ 
Caught in the paradox, the deportee writers move at times uneasily between two poles, two tendencies: their accounts may be modelled on non-fictional genres (the memoir or journal, for example) and they deploy a range of devices which function to reinforce their authenticity and factual status (prefaces, footnotes, appendices), but they also, as this chapter aims to discuss, use a full gamut of stylistic devices one might more readily associate with realist fiction.

\section{Judging by the cover}

As the first point of contact between reader and author, and playing a key part in any marketing strategy the publisher may have, the titles of the accounts inevitably send out certain signals, tying most obviously into readerly expectations of genre. Perhaps surprisingly in the case of this corpus, titles do not always signal the subject matter of the accounts explicitly, nor do they necessarily adopt what might be regarded as an appropriately sober tone. Si tu t'en sors (1992); Sursis pour l'orchestre (1976); Le Temps écartelé (1980); Les Chemins du temps (1977); La Traîne-sauvage (1999); Le Piano rouge (1990), for instance, all have personal significance for their authors, but give little initial direction to the reader. Other titles are more striking, and considerably less neutral in tone: J'ai donné la vie dans un camp de la mort (1997); Femmes à tuer (1984); Dans les griffes nazies (1946); Sous la schlague (1965); Face à Barbie (1987). While these titles stress the violence of the camps, others focus on different facets of deportation, for example, survival (Souvenirs d'une rescapée, 1974; La Douceur de revivre, 1970); an emphasis on an ethical imperative (Pour que demain soit liberté, 1992; Il faudra que je me souvienne, 1994); combat and resistance (Toute une vie de résistante, 1998; La Victoire en pleurant, 1967; Pour la France, 1946).

A more laconic and informative title serves to situate the text more clearly within the documentary tradition: Le plus long des chemins: de Marseille à Auschwitz (1997); Journal de Ravensbrück (1995); De Fresnes à Ravensbrïck (1982). Only those accounts published in the immediate post-war years bear more specialised titles, their authors perhaps relying on the fact that media saturation had informed their potential readership of the terminology in question: Nuit et brouillard (1945); N.N. (1946); Sous le signe du triangle (1946); Triangle rouge (1946). ${ }^{3}$ The titular citation of the deportee 'matricule' (the number assigned to each deportee within the camps) paradoxically both stresses the depersonalisation of the camp regime and places emphasis on individual experience: Déportée 50.440 (1946); Matricule 19374: afin que nul n'oublie (1986); J'étais le numéro 47.177 (1973); Coma: Auschwitz, no. A5553 


\section{Textual identities II: textual constructs}

(1996); J'étais le numéro 20.932 à Auschwitz (1988). In the majority of these cases the distinction between Jewish and non-Jewish deportees is not signalled, though in the public imagination the 'matricule' may well be erroneously conflated with the tattoo. ${ }^{4}$ Indeed, only in rare cases is the status of the Jewish deportee indicated: Une Française juive est revenue (1946), and less explicitly, Vivre après la Shoab (1998) and Coupable d'être née (1997), are rare exceptions.

Attempts to align the experience of the camps with an existing paradigm are manifested in two principal groupings. The first includes allusions to hell and death, with subtitles often providing a more explicit indication of the particular hell in question: Terre de détresse: Birkenau, Bergen-Belsen (1995); Sortie de l'abîme (1994, subtitled 'Memoirs of a deportee'); Jeunesse vers l'abîme (1992); Voyage en enfer (1946, with the gloss the moving tale of a Ravensbrück survivor'); Ravensbrück: l'enfer des femmes (1945); Infernal rébus (1946); Jusqu'au rivage des morts (1979); Hors la vie (1946, subtitled 'Journal of a deportee'). The second grouping alludes to the tradition of the 'bagne' (penal colony), most commonly associated in a French context with deportation to, and forced labour in, New Caledonia: Birkenau: bagne de femmes (1945); Scènes de la vie de bagne (1947); 2 ans de bagne de Ravensbrïck (1992). Given that consignment both to hell and to the penal colony connote the wrong-doing of the individual, the choice in these cases is far from apposite. Dufournier's titular allusion to the penal colony - La Maison des mortes: Ravensbrück (1945) - and the many allusions to the Gulag which can be found in the body of several accounts are perhaps more fitting, though here too comparisons between the Nazi, Tsarist and Stalinist régimes are of course highly problematic.

In many cases additional cover information and an indication of the collection or series in which the accounts appear key to reader expectations. Authenticity is frequently stressed: Simier's 2 ans de bagne de Ravensbriick (1992) bears the prominently displayed gloss 'document written in 1945'. The cover of Busson's Dans les griffes nazies (1946) informs us of the author's credentials - 'Military Cross 1939-1945' and points out that photographs within the text are supplied by the Ministry of Information. Generic paradigms are commonly invoked: Heftler's Si tu t'en sors forms part of the 'La Découverte: témoins' collection; texts by Abadi, F. Christophe, and Schapira feature in the 'Mémoires du XXe siècle' series (though as we will see they do not, in fact, conform to this genre), while both le Guillerme's Hors la vie and Marette's J'étais le numéro 47.177 suggest that these are examples of the 'journal' (though again, they depart quite radically from generic 
conventions). Although there is little scope for extensive discussion here, changes in cover information can prove to be highly revealing of market trends: in its original 1970 edition, Friang's Regarde-toi qui meurs appeared in the 'vécu' collection (published by R. Laffont). By 1972 it formed part of 'l'aventure aujourd'hui' series (published by J'ai lu), before finally finding a place in 1997 in the 'Résistance' collection of Éditions du Félin.

\section{Paratext}

Prefaces, footnotes, appendices and embedded documents or photographs all fulfil an authentificating or legitimising function, serving in addition to differentiate the accounts from fiction or literature. Although prefaces may be written by the deportees themselves, in many cases, third parties - often high-profile figures - lend status and authority to the texts, their names in some cases featuring on the cover of the accounts ('Preface by Elie Wiesel, Nobel Peace Prize laureate', 'Afterword by Bertrand Poirot-Delpech of the Académie française' in the case of Lagrange's Coupable d'être née; 'Foreword by Rémy's on the cover of Renault's La Grande Misère; 'Preface by Pierre Vidal-Naquet' on Maous's Coma: Auschwitz, no. A5553). Strikingly, with one exception that of Geneviève de Gaulle(-Anthonioz), who prefaces the accounts of Bauer, Jeannin-Garreau, Lasnet de Lanty, Lesèvre, and AylmerRoubenne - the prefatory privilege is usually given over to men, often those with sound Resistance or, perhaps unexpectedly, literary credentials: Jacques Chaban-Delmas; Robert Chambeiron; Marcel Conche; Stéphane Courtois; Serge Klarsfeld; Mauriac; Lucien Neuwirth; Jean Nocher; and Maurice Schumann all feature. ${ }^{6}$

In nearly all cases footnotes are written by the authors or remain unattributed. Where a third party is explicitly involved, as in Heftler's Si tu t'en sors, the notes of which were composed by Anise Postel-Vinay and Annette Wieviorka, the aim may be to provide supplementary or corrective informative. Thus, Heftler's suggestion that medical experiments carried out on twins at Auschwitz were restricted to measurements and blood tests is countered by a note stating otherwise: 'In fact, we know today that some of these experiments were extremely cruel and often led to death' (1992: 117, footnote 1). Paradoxically, the correction serves to highlight both accuracy and facticity, simultaneously foregrounding the unexpurgated - and thus more authentic nature of the account. When composed by the authors themselves, footnotes may be as subject to error in detail (and especially number) as the main body of the texts. Lagrange, for example, claims that a red 


\section{Textual identities II: textual constructs}

triangle marked ' $F$ ' signifies a 'left-wing French detainee' (1997: 57, footnote 3), while Améry states that 4 per cent of those deported to the Nazi camps returned (1945: 159, footnote 1$){ }^{7}$

The most widespread function of footnotes is to provide explanations of camp jargon and terminology (for example, 'Blokowa' [deportee placed in charge of a block]; 'Revier' [hospital block]; 'Aufseherin' [female SS guard]), or translations of German speech, the inclusion of which in unglossed form in the main body of the text both increases authenticity and highlights the alien nature of the world of the camps. Notes may also seek to provide corroborating 'evidence' from other sources: statistics collated by Serge Klarsfeld appear in some later accounts, as do occasional references to other deportee accounts. Finally, footnotes may serve to update material from a later standpoint of greater knowledge: 'This man did not keep his word, he did not notify my family' (Saint-Clair 1945: 44, note 1, referring to a chaplain who had promised to inform the author's husband of her deportation). Appendices fulfil a similar function to footnotes with some additions: several texts append brief informative sections (on, for example, the lives of individuals who feature in the main body of the text, or Resistance networks), while others fulfil a commemorative function, listing the names of deportees mentioned in the body of the text and outlining what became of each.

If prefaces, footnotes and appendices play their part in reinforcing the authenticity and facticity of the accounts, so too does the inclusion of material such as letters (written, for example, by the deportees, or by various members of the German and Vichy authorities), photographs and maps (of both individual camps and the spread of camps across the Reich, often executed by hand). A distinction should be drawn between photocopied material and those documents which are merely cited or retyped, the latter providing a reduced pull towards authenticity. The same distinction can be made with respect to the inclusion of sketches in some accounts: whereas Benoist-Lucy's text appears to have been illustrated after the event, original drawings (that is to say, those executed in the camps) can be found in, for example, the first edition of Maurice's N.N., Busson's Dans les griffes nazies, and Lasnet de Lanty's Sous la schlague. The urge to include graphic material to complement the written word is at its strongest in two texts: Elina's Sans fleurs ni couronnes comprises a series of short entries with illustrative sketches; Jeannin-Garreau's Les Cris de la mémoire (the Preface informs us that each drawing represents a 'cry') comprises charcoal drawings on each right-hand page, with short passages of text on the facing pages. 


\section{Structural concerns}

When it came to the act of writing the deportees were faced with a series of structural and formal choices, which for the sake of clarity can be reduced here to two key questions: what temporal span would be narrated?; in what order would events be narrated?

\section{Arrest to return}

Although the corpus inevitably demonstrates a degree of variation, the norm is for the main body of the deportee account to span the period 'arrest to liberation' (or 'return to French soil'), and to present events in a broadly chronological order. ${ }^{8}$ Very few texts comprise a reduced time-span; one exception is Geneviève de Gaulle-Anthonioz's La Traversée de la nuit (1998), a short account of the period of several months spent by the author in the Ravensbrück 'Bunker'. ${ }^{9}$ Similarly, few writers choose to break radically from a broadly chronological exposition of events. Notable exceptions in this case are Fénelon and Brun, both of whom employ the literary device of the flashback. It is worth noting that in Brun's case this device is deployed only in early part of the text. Many of the accounts open in a stylised manner (often in medias res, and often with a great deal of direct speech), subsequently retreating to a more unembellished narrative at the point at which the author's integration into the concentration camp routine is recounted. The brutal reality of camp life, the entry into a radically unfamiliar world, are apparently incompatible with an overtly 'literary' structure. ${ }^{10}$

The deportees rarely comment on structural imperatives, but the perceived need to adhere to a linear exposition of events is occasionally articulated. Abadi, for example, explains that once she had completed her account, she realised that it was 'indecipherable to non-deportees', and consequently made a lot of cuts, 'keeping only material structured around a chronological axis' (1995: 9). In fact, no account adheres strictly to a purely chronological exposition. As Reiter (whose focus is on German-language texts) points out, the opening and closing sections of deportee accounts (the narration of arrest, deportation and arrival at the camp, and that of the final days in captivity) tend typically to be narrated in greater detail and in chronological order, with the middle sections of the texts often breaking into a more anecdotal or episodic form (2000: 150). A 'typical' account is thus articulated around a chronological axis, with key events and dates noted (for example, a move to another camp, the sickness or death of fellow-deportees, 


\section{Textual identities II: textual constructs}

notable dates such as Christmas and 14 July). Given that the daily routine in the camps was, however, depressingly repetitive, the chronological thread tends to be interspersed with episodic or thematic sections. In this respect the chapter headings of Busson's Dans les griffes nazies can be taken as representative of many accounts: the early period from arrest to arrival spreads over a number of chapters ('First contact with the Gestapo', 'Angers', 'Fresnes: Cell 425'); the section entitled 'Ravensbrück' then splits into themed or episodic form ('Block 23', 'Song of the Marshes', 'Block 32', 'Visions of Hell', 'Punishments', 'Misery and Overcrowding', etc.), after which the narrative reverts to a broadly linear form.

The balance between the chronological and the episodic is, however, more varied than Reiter suggests, with the episodic taking precedence in some cases. Maurice's N.N., for example, includes very few temporal markers and comprises a series of short anecdotal sections interspersed with poems and sketches. Hollander-Lafon's Les chemins du temps consists of very brief sections ('A Day', 'Lice', 'Man and Bread', etc.), often two or fewer pages in length. There is no linear narrative thread and, indeed, the reader may struggle to ascertain when and where narrated events take place. As well as breaks in linearity occasioned by anecdotal or thematic interludes, many accounts introduce narrative 'pauses' in order to elucidate certain aspects of camp life, in some cases breaking the narrative thread with metatextual comments. Picard's intervention is typical: 'I don't think I've mentioned the SS system of deportee categorisation. Maybe I should have done so sooner. It didn't occur to me while I was recounting my arrival in the camp' (1995: 52). Picard duly explains the system of triangular markers, before taking up where she had left off.

\section{The journal}

A purely linear narrative is thus unusual, but one category of text which might be expected to adhere to a chronological unfolding of events is the journal, of which there are (apparently) six examples in the corpus: Alcan's Sans armes ni bagages; Gorce's Journal de Ravensbrïck; le Guillerme's Hors la vie (subtitled 'Journal of a deportee'); Marette's J'étais le numéro 47.177 (subtitled 'Journal of a deported actress'); Novac's Les beaux jours de ma jeunesse; and Saint-Clair's Ravensbrïck: L'enfer des femmes. ${ }^{11}$ In spite of their designation as journals, these six texts depart to varying degree from generic conventions, which might reasonably include: the writing of daily or at least frequent records in situ; the presence of two distinct time-scales - that of the writing act 
and the written event; a non-teleological structure; a relative absence of certain stylistic features such as, for example, extensive dialogue.

Although subtitled 'journal', Marette's account includes no distinct entries, and no references to the writing act. It opens with a single date - '27 January 1944' (1954: 13) - but the remaining text runs on undated and indeed with no textual divisions of any sort. Gorce's account does on occasion flag up the act of writing within the camps ('I'm writing by the light of the stove', 1995: 125), but for much of the text the reader is afforded little insight into when the recorded events took place or, indeed, when they were inscribed. Dates appear only midway through the text (starting ' 14 January 1945', ibid.: 90), a single date heading each chapter until Chapter 13 which comprises several dated entries. A measure of authenticity is introduced when it is suggested that the author loses track of time, as signalled by the replacement of an accurate dating process by less specific headers: 'Saturday... March' (ibid.: 128). Given the nature of both of these texts, it could be suggested that the generic attribution 'journal' functions as a marker of authenticity and facticity rather than an accurate descriptor.

Le Guillerme's and Alcan's accounts differ from Gorce's and Marette's in that they do adhere to the expected convention of dated entries, le Guillerme, like Gorce, alternating specific dates with headers suggesting a temporary loss of temporal co-ordinates: '.. February' (1946: 125-7). What is striking in both these cases, however, is that in spite of the apparently dutiful recording of events as they unfold, both authors indicate that they actually wrote their 'journals' after their return from the camps: 'I wrote this journal on my return' (Alcan 1947: 7); 'This journal has been written from memory, without using any written notes' (le Guillerme, 'note from the author', 1946: unpaginated). Given the frequency and apparent accuracy of the dating (le Guillerme's text comprises an almost daily record of events), it is hard to comprehend quite how such an accurate temporal record could have been recalled - quite apart from the fact that a journal is not conceived of as a retrospective account of events. These texts too can thus perhaps best be described as 'pseudo', which is not to say fictional, journals.

Further departures from the norm include stylistic and in some cases formal properties more readily associated with realist fiction than the journal: extensive dialogue or direct speech; chapters (Gorce employs roman numerals, le Guillerme, 'Life in a Cage'; 'Stalag Compiègne'; 'Special Convoy', etc.); highly stylised passages typified by opening lines: '- German police ... Follow us and don't make a 
fuss. The voice whispers in my ear: a Corsican accent' (le Guillerme 1946: 7):

At lunchtime - in the flat where we took refuge after we'd repeatedly shaken off the Gestapo - my husband seems very unsettled. I ply him with questions.

'Come on, tell me, what's wrong?'

'I think it would be safer for us to leave.'

'Again! Why?'

(Marette 1954: 13)

For the most part, the authors do not display knowledge of future events, indeed the non-teleological nature of the account may be emphasised by comments such as Alcan's reference to a French soldier: 'His name is Martin. I'll never forget him... if I return' (rather ironically, given that Alcan's 'journal' was written after she had indeed returned). There are, however, exceptions. Alcan, for example, also informs her reader that: 'During my time in captivity I was really scared on two occasions: scared of being interrogated, and once in the camp, scared of dying' (1947: 15).

Saint-Clair's Ravensbrück: L'enfer des femmes is also peppered with passages of direct speech, and loses some credibility as a journal due to the prodigious length of some entries, which were apparently composed within a single day (the section headed ' 13 October', for instance, described under the following entry as 'the pages written yesterday', 1945: 107, extends to some 7,700 words). Authorial comments, however, do lend the text greater verisimilitude as journal. First, Saint-Clair refers frequently to the act of writing. More specifically, she is at pains to indicate one of the key difficulties any diarist faces - a difficulty which is inevitably exacerbated in the context of the camps - namely finding the opportunity to write and keeping up with the material which is to be recorded. Comments to this effect punctuate the text at regular intervals: 'I'm forcing myself to note things in order. So much happens here every day that ideally, I would write on a daily basis, but I can't' (ibid.: 45). Indicative of the struggle to maintain a chronological record of events, for much of the text each dated entry begins in the temporal plane of the present writing act before returning to narrate recent events.

As with Saint-Clair's 'journal', Novac's Les beaux jours de ma jeunesse gains much of its authenticity from its author's reflections on the writing act and the problems faced when attempting to keep a regular record of events: 'I'm writing on an upturned crate' (1996: 123); 'P.S.: 
I wrote all this sitting under the gutter' (ibid.: 235), but also 'I have to hurry, the new material is accumulating at a dangerous rate' (ibid.: 46). In fact, Novac, perhaps more than any of the writers under consideration in the corpus, articulates some of the epistemological issues at stake in the writing endeavour. She acknowledges the inevitable process of selectivity ('Which reminds me of an incident I haven't recorded (you can't record everything)', ibid.: 47), the necessarily subjective nature of her account ('I admit that I'm only one witness among many ... How could I possibly claim to be giving a comprehensive account of the camp?', ibid.: 70-1), and the potential unreliability of second-hand reports from eye-witnesses ('In this place someone has always seen everything (with their own eyes), and there's always someone who will swear to it', ibid.: 21). ${ }^{12}$

Although Les beaux jours breaks down into short entries separated by asterisks, these are undated. Indeed, the text is devoid of dates, though these can be construed from references to recorded events: 'In the morning the Czech camp was empty' (ibid.: 211) situates the narrative in early March 1944 (the liquidation of the Czech camp took place on 7 March of that year); 'An Italian transport is apparently going to be crammed into our block. In fact, they're Greek women from Rhodes' (ibid.: 225) refers to the round-up of Greek Jews from the island of Rhodes on 18 July 1944, and their arrival in Auschwitz on 16 August 1944. In this case the lack of dates coupled with references to recognisable events adds authenticity to the text, as does the impression of chaos communicated largely by the relative absence of expositionary glossing and the author's naïve early stance. Novac's failure to grasp the horrific realities of the camp - 'One thing is certain: there are no children here in the camp. Or old people. They must be somewhere' (ibid.: 22) - contrast sharply with later revelations: 'Didn't you know? They're incinerated. Calm down, not alive! They're put in the gas chamber first' (ibid.: 210). ${ }^{13}$

There is, however, a single phrase in Les beaux jours which may cause the reader to hesitate. Early in the text Novac attributes the following words to fellow-deportee Sophie: 'So what? What does it matter! Isn't everything bringing us closer to the final solution?' (ibid.: 29, my emphasis). Novac's use of a by-now familiar phrase, but one which was unlikely to have been known to her in early 1944 may be coincidental, but it flags up a fact which applies to all of the 'journals': the published text is not an unadulterated transcription of words written in the camps. Though Novac may state just prior to the start of the 'journal' per se, as she peers at the faded inscriptions she kept in the camps, 'I'm just copying the material out again' (ibid.: 13), a certain 


\section{Textual identities II: textual constructs}

amount of reworking has inevitably taken place. Novac's journal is (precociously) elegant and mannered. The author refers to her desire to find 'the right word, the most effective word' (ibid.: 71), and to the repeated reworking of material, but just how much rewriting was carried out years after the event, and how much in the camps themselves, remains impossible to ascertain.

Novac's self-confessed obsession with style brings us back to the paradox of the highly literary text which is 'not literature'. She affirms that facticity is all-important: 'There is only one master here, the fact. I'm just a scribe in its service' (ibid.: 25-6). Yet the image of the scribe is a telling one, returning us to Young's insistence that an emphasis on 'seeing', on the role of the eye-witness, is a rhetorical device, invoking as it does the Pentateuch as paradigm and the scribe as mere instrument of the events recorded (Young 1987b: 408-11). ${ }^{14}$ Novac, indeed, seems uncertain about the status of her own text, and the motivation which pushes her to write. The author insists that she writes for posterity: 'it goes without saying that I'm not writing for myself. May these notes figure among the witness accounts on the day of reckoning!' (1996: 71), yet it is clear that her keeping of a journal is also a means of preserving a sense of personal identity and of resisting the system: 'This mangled object [a pencil], snatched from the mud, is secretly giving me back everything that a world of fanatics is trying to take away from me: the joy of saying "Sod you"!' (ibid.: 17).

Such authorial comments signal a high degree of introspection. More than any of the other authors of a 'journal', Novac engages in the sustained self-analysis and reflection associated with this genre, and for this reason her text stands out as something of an exception. ${ }^{15}$ As Foley points out, '[p]rivacy and particularity are characteristic of the traditional diary. In the Holocaust diary, by contrast, personal experience cries out to be acknowledged as a register to the fate of a whole people' (1982: 336). ${ }^{16}$ Indeed, in the majority of cases, the deportee authors depart from autobiographical norms: their truth is not theirs alone but that of a collective; the first person singular often gives way to the first person plural 'nous'. ${ }^{17}$ In many respects - though by no means all - the deportee accounts can be compared to the genre of 'testimonio' most commonly associated with Latin American writers. ${ }^{18}$ Whereas in the case of autobiographical forms the subject deliberately uses and appropriates literature for self-expression, in testimonio, the narrative 'I' represents a community or collective (Beverley 1996: 35-6). As with deportee accounts, testimonio can be characterised as 'an authentic narrative, told by a witness who is moved to narrate by the urgency of a situation' (Yúdice 1996: 44). As is also the case with 
the deportee accounts, testimonio reveals and is born of an urgency to communicate and to bear witness. The reader is interpellated in both instances, and in both instances it is sincerity and not style which is

paramount: 'The position of the reader of testimonio is akin to that of jury member in a courtroom. Unlike the novel, testimonio promises by definition to be primarily concerned with sincerity rather than literariness' (Beverley 1996: 26).

\section{Beyond 'arrest to return': the memoir}

The accounts considered so far do not extend beyond the 'arrest to return' framework. Those that do, tend to fall into two categories: either the temporal span is extended to include substantive material which both predates the authors' arrest and postdates their return from the camps, or the texts encompass the years preceding arrest but are end-stopped at the moment of liberation and return. Given the wider time-span in question, both of these categories might be seen to come closer to the genre of the memoir than those accounts which are more temporally circumscribed, though here too there are significant departures from generic conventions. Foley states that 'a sense of distinct individuality is signally lacking in most of these narratives' (by which she means that such texts are all remarkably uniform in tone and content), and points to a 'reversal of the traditional pattern of growth' (1982: 337-8). This view is echoed by Reiter, who suggests that the 'developmental pattern' of the memoir genre is lacking, the accounts centring instead on 'an identity which, precisely because of what is described, has lost its self-assuredness'. The accounts, Reiter suggests, might thus best be described as 'anti-memoirs' (2000: 57).

To a certain extent, these claims are well founded. A significant number of texts in the corpus include details of their authors' family background, their formative years and their lives prior to deportation. It is striking, however, that although these accounts extend beyond the 'arrest-return' temporal span, they are highly asymmetrical: life before the camps may be narrated in some detail and at some length, but in spite of the fact that all of the accounts which fall into this category were written in the $1980 \mathrm{~s}$ or $1990 \mathrm{~s}$, the narrative comes to a halt immediately after the moment of return from the camps. As Foley notes:

The great majority of Holocaust memoirists fall silent when they have completed their tales; at the moment when individuality 


\section{Textual identities II: textual constructs}

could be resumed - or at least an account of the meaning of what they have endured might be offered - the voice recedes, or falters.

(1982: 339)

Such asymmetry bears out Foley's and Reiter's claims. The life-story is only a partial life-story: it seems that in spite of the intervening decades, the deportees cannot, or do not wish to, extend their narrative beyond the camps. Foley identifies a 'four-part development' in the concentration camp memoir: 'innocence, initiation, endurance, escape', the latter characterised as 'the return to a life that can only parody "normality"' (ibid.: 338-9). The end-stopped asymmetrical 'memoirs' do indeed suggest that 'normal' life in some cases could not and did not resume. Perhaps it is felt that to discuss what came after is either irrelevant or irreverent. It is perhaps to be expected that the majority of accounts which adhere to this pattern were written by Jewish deportees: not only do Jewish authors come to writing later (as has been noted); their experiences were often considerably more traumatic than those arrested as political deportees.

Foley and Reiter appear to base their conclusions on those endstopped accounts which come to a close with the narration of the return of the deportees, but there are accounts which extend beyond the narration of their author's liberation and return. Such texts, the structure of which indicates a measure of integration of the concentration camp years, can be differentiated from Foley's and Reiter's categorisation and characterisation of the camp 'anti-memoir'. Part I of Marmor's Le Piano rouge (1990) consists of an account of the author's birth and upbringing close to the Austro-Russian border, the family's move to Vienna in 1914 and thence Paris. Part II details Marmor's deportation to Auschwitz-Birkenau, and Part III her return and life up until the period of writing. Friang's Regarde-toi qui meurs (1997) falls into two sections, the first of which accelerates through the author's formative years, focusing primarily on her Resistance activities, arrest and deportation, the second describing Friang's life after 1950. Finally, Paul's Ne me jugez pas (1962) moves from a description of the family's background to the author's involvement in the Resistance, her deportation, escape from Ravensbrück, and life up until the early 1960s. ${ }^{19}$

Significantly, all three of these writers were to go on to engage in high-profile public lives after the war: Marmor became a successful singing teacher whose pupils included Sacha Distel, Sylvie Vartan and Romy Scheider; Friang a war-correspondent who witnessed and reported on events during the Suez Crisis, Vietnam and Six Day Wars; Paul, infamously, was jailed for murder. Drawing on the work of Bernd 
Neumann, Reiter points to a useful distinction between autobiography and memoirs, describing the former as concerned primarily with 'the development of the personality' and the latter as the 'practical testing of the author in public life'. Reiter discards both categories as inappropriate in the case of the concentration camp memoir, which she suggests reveals an identity 'which has lost its self-assuredness' rather than 'the genesis of the individual' or 'the individual as bearer of a social role'. Reiter alludes to Langer to support her argument: the accounts, she states, 'depict people whose hands are tied, who do not take any far-reaching decisions of their own, and who can take active responsibility for their lives only in the most exceptional situations' (Reiter 2000: 57). ${ }^{20}$ Texts such as those by Marmor, Friang, and Paul, however, belie Langer's typically gloomy prognosis. Deportees could and did go on to operate in public life (Paul, admittedly, rather unwisely), as their memoirs reveal.

\section{Beyond 'arrest to return': the dialogic text}

Brief mention must be made here of another structuring principle, that of counterpoint or the juxtaposition of different temporal perspectives. Although many of the texts in the corpus break off the narration of events in the camps to introduce a later temporal perspective, such interventions are often limited to a brief observation or comment. Few texts shuttle between temporal zones in a sustained manner. Those that do, such as Alcan's Le Temps écartelé (1980) and Crémieux's La Traîne-Sauvage (1999), provide a rare reflective gloss on past events and, in Crémieux's case, on the writing act itself.

Following the common pattern, Alcan's account opens in the early 1940s, narrating the author's arrest on 6 December 1943 and subsequent deportation to Auschwitz. A description of living conditions in the camp is then interrupted by two intercalated proleptic passages: the first refers to the infamous interview of Louis Darquier de Pellepoix in L'Express on 30 October 1978; the second describes the author's visit to Birkenau on 26 February 1979 (1980: 40-1). This contrapuntal movement between events in the camps (including the evacuation of Auschwitz and death-march to Ravensbrück) and those dating from later decades is sustained with further proleptic material, including: a brief description of a reunion of deportees held in Paris on 28 January 1979 (ibid.: 64); reference to an interview on German television of three members of the Auschwitz SS who had been condemned to life imprisonment at the 1964 Frankfurt trial (ibid.: 66); an organised visit to Birkenau for youngsters filmed by a French television 


\section{Textual identities II: textual constructs}

channel on 26 February 1972 (ibid.: 69). Alcan also intercalates a range of documents in her narrative: a letter written by Goering dated 31 July 1941 referring to the extermination of the Jews (ibid.: 54); segments from the transcript of the trial of Hoess in Warsaw (ibid.: 63); extracts from essays written by school pupils who participated in the 'Concours de la Résistance' held in Paris in 1965 (ibid.: 76). Although no explicit comments are made by the author, the dialogic juxtaposition of temporal planes provides an unwritten gloss on events, highlighting contrasting perceptions of the camps: negationist claims are framed by an account of the Blocks in Auschwitz and the author's traumatic return to the camp; the schoolchildren's versions of deportation contrast strongly with the author's. The power of the text stems from its silences: it is up to the reader to draw conclusions.

Crémieux's La Traîne-sauvage is also a dialogic text which introduces a degree of temporal layering, though it differs radically from Alcan's. The account - which might more accurately be called a 'meta-account' - was co-written by Crémieux and Pierre Sullivan (both psychoanalysts) and was based on monthly conversations on the subject of the author's deportation which were subsequently written up and glossed by both Crémieux and Sullivan. The text comprises three narratives or voices: Sullivan's comments and observations appear in roman type; Crémieux's memories of the camps (which emerge in response to prompts from Sullivan) and her responses to Sullivan's comments feature in italics, as do unexpurgated notes made by her immediately after her liberation and letters which she sent home during her incarceration. Crémieux likens the enterprise to a psychoanalytic cure (1999: 10). Feelings of guilt (she alludes to a seminal moment when she stole the bread of a fellow deportee) have been such that heretofore she has been unable truly to face the past. The result of Crémieux's dialogic exchange is a highly reflective and reflexive account which tells us as much about the mechanisms of memory and the writing act as it does about the camps.

\section{The sense of an ending}

Thanks to her dialogic exchange Crémieux achieves a degree of closure at both a personal and a textual level: the author's guilt is put behind her, her (meta)account concludes with the words 'We've reached our destination together' (ibid.: 150). If the critics are to be believed, however, such a degree of resolution is rare. Concentration camp authors, according to Foley, opt for silence when 'an account of the meaning of what they have encountered might be offered' (1982: 339). Reiter 
makes a similar point: 'It is not so much the quality of the story related in the concentration-camp reports that makes them depressing to read but the lack of an overall meaning' (1991: 277). ${ }^{21}$

Although judging whether an account is, indeed, 'resolved', whether its author articulates a 'meaning', is inevitably a complex enterprise, one indication might reasonably be sought in the manner in which the accounts come to a close. Many, as might be expected, do indeed bring their texts to a conclusion which offers only disillusionment and lack of understanding, the authors in many cases adding a brief afterword or commentary to the material which comprises the main body of the account. Gorce, for instance, ends her narrative at the point of her return to France and the strains of the Marseillaise, but her text runs on for a further page which focuses on the death of her friends and undercuts the potentially 'happy ending'. Personal circumstances inevitably dictated the tenor of the ending of individual accounts: Busson's text concludes with the despair of the author as she returned to learn of the death of her husband; Tichaeur's account of her return to France is followed by an epilogue in which she records the death of her family and her own inability to have children. As is often the case in the accounts, Tichauer offers a slim measure of optimism when she states that she was saved from total despair by work and her political beliefs, but this does little to counter the bleak conclusion, and the text ultimately can do little more than close on the articulation of a hope for peace in the future. The implication that if the war had led to peace or radical social changes then some meaning might have been extracted from events is a common one, but such hopes were rarely realised. Saint-Clair closes her text on a bitter note as she returns to find France unchanged, as does Alizon, whose epilogue 'What was it like to come back?' stresses the author's disillusionment.

More often than not, however, the accounts conclude on an unexpected note of ambivalence. The horrors of suffering and death are acknowledged, but these are often counterbalanced by more positive observations: many deportees describe their time in the camps as a 'learning experience' (Benoist-Lucy typically refers to a 'tough apprenticeship', 1994: 107) which affected great changes in them (the image of a rebirth is widespread), and prompted a radical reappraisal of values. The positive qualities of solidarity, friendship and generosity are repeatedly highlighted. The afterword of Maous's account, for example, points to the dangers of negationism and fears of a possible repetition of events, but it also bears a message of hope for those who might find themselves in a similar situation: 'we cling to life come what may' (1996: 178). Abadi, in a closing section of her account may 
stress the horrors of so many deaths and her dismay in the face of new conflicts, but she also finds room for an optimistic note:

What we now know beyond doubt is that in the midst of the most terrible ordeal, our greatness and strength lay in our solidarity. What we have learned is that absolute misery, suffering, and the constant presence of death can bring out amazing and unexpected qualities in people, and that the friendship of these individuals, their tenderness and courage, kept us going and sometimes saved our lives.

(1995: 176)

Again, the circumstances of writing play a key part. Touboul's first version of her account (1982) emphasises the alienation of the returning deportees, while the concluding section of the second edition (1997) introduces a more upbeat reference to the author's marriage and four children. In some cases the pattern is reversed: Dufournier's first edition of La Maison des mortes (1945) closes on an account of the author's return to France and the first two lines of the Marseillaise. The later 1992 edition is rather less sanguine: the problems of reintegrating into society come to the fore, and the Marseillaise is replaced by the author's description of how she informed the husband of a fellow-deportee of his wife's death in the camps.

Saint-Clair's upbeat ending on the French national anthem in her 1945 edition typifies those accounts written immediately after the end of war, at a time when relief and the euphoria of survival perhaps had yet to fade into disillusionment. Certainly these early texts show little negativity, but rather joy and a combative spirit. Améry's Nuit et brouillard (1945) closes with the defiant words: 'I was ready to kill some SS!' (ibid.: 182). Roux's Triangle rouge (1946) stresses the enormity of the experience (echoed in Lasnet de Lanty's 'THE BIG ADVENTURE IS OVER ..., 1965: 259), and ends with the clichéd images of a rainbow and a new dawn. Wilborts's Pour la France (1946) claims that all the pain endured has been forgotten, that the preceding events have been worth the suffering: 'Because nothing is too good for you, France, my country' (ibid.: 143). While such combative spirit and apparent optimism might be expected in texts written so soon after the deportees' return, it is striking to note that later texts often show a similar defiance. Written in 1967, the epilogue to Toulouse-Lautrec's $\mathrm{La}$ Victoire en pleurant recalls the questions frequently put to the deportees on their return ('Did you suffer a lot?'), and emphasises the heroism, generosity and humour of those in the camps ('so much laughter'), 
before closing on the answer: 'No, it's not what you think, we had some fine moments, we suffered a great deal, but we have no regrets' (ibid.: 351). Picard's description of her return to France in Des ténèbres à la lumière is followed by an account of the author's conversion to Christianity and the potentially shocking statement: 'Never once have I regretted the fact that I was deported' (1995: 219).

The case of Picard is an extreme one: in her case the suffering endured could be integrated into a Christian paradigm, but what of the other notes of optimism sounded in so many accounts? Granted, these might be interpreted as defensive constructs: the deportees strive to accentuate the positive in order to mask the truth of despair; ${ }^{22}$ after all, events and activities which would be taken for granted by those who have not undergone the ordeal of the camps (marriage, the birth of children, employment) are described as essential wonders by many of those who return from camps. But perhaps such a dismissal is too glib. As was suggested in Chapter 1, it is important not to pathologise the deportees en masse but to listen to what they have to say. The trauma of the camps was bad enough; perhaps one should not expect the deportees to suffer indefinitely. ${ }^{23}$ Of course one final point must be borne in mind: the vast majority of those deported did not write of their experiences. It may be that those who did were precisely those who recovered best. The accounts necessarily bear witness to their authors' capacity for a degree of distanciation and disengagement from the past.

\section{'Un peu d'artifice': communication and reception}

The textual aspects considered thus far - titles, paratext, and structural paradigms - all of which typify the non-fictional text, serve to reinforce the authenticity and facticity of the accounts. The following section seeks to analyse those elements of the accounts which potentially come into conflict with the proclaimed factual status of the accounts. The shifting play of tenses and pronouns, use of direct speech and dialogue, tone, apostrophe, humour, irony, metaphors and intertextual material might all be regarded as having little place in a factual document. True to the paradox articulated by Semprun, however, it will emerge that such literary and rhetorical traits can be seen to function as aids to communication and, although not always successfully, as a means to create the all-important verisimilitude required to generate an acceptance of the 'truth' and facticity of the accounts. ${ }^{24}$ 
70 Textual identities II: textual constructs

Temporal dislocation and the suspension of disbelief: the use of tenses

One of the decisions faced by the deportee-authors was that of tense usage. Given the retrospective nature of the accounts a predominant use of the past tense might be anticipated. One might, indeed, expect the perfect tense to prevail, both because the alternative - the preterite - is usually regarded as more 'literary' (and these are, apparently, completely un-literary texts), and because the perfect tense signals an existential link with the present which might seem appropriate to those who cannot readily put the past behind them. In fact, however, the majority of the accounts are written in the preterite, with a high proportion favouring a sustained use of the historic present. While a comprehensive study of tense usage cannot be undertaken here, the analysis of a number of examples may serve to highlight one widespread phenomenon: the fluctuation of tenses within individual accounts.

The first example records the traumatic event of a 'selection' of deportees:

Was the method of natural selection deemed to be too slow? During the month of March two hundred and fifty pregnant women and twelve infants were gassed [on gaza: preterite]. A state of disorder, like a madness, bas taken over [s'est emparé: perfect] the camp. The SS have never been [ne furent: preterite] more nervous. The most contradictory of orders assail us, the gas chamber and crematorium are functioning at full capacity. A power plant bas been destroyed in the bombing. We bave been without electricity for several days. In the dark, the cold, in silence, mothers come to check that their babies are still alive. Their bellies are bloated, their skin hangs loose, their eyes are huge and hollow... One evening a friend of Nora, an Italian, asked me [me demanda: preterite]: 'Would you sing to him?'

(Aylmer-Roubenne 1996: 93-4, my emphases; author's ellipsis)

As is so often the case with the accounts, various temporal layers collide in this extract. The opening rhetorical question pulls the reader (who assumes the role of addressee) briefly into the compositional present, before the preterite and impersonal pronoun ('were gassed') reestablish distance. A moment of oscillation between past and present is then introduced with the perfect tense ('has taken over'), before a series of historic presents ('assail', 'come', 'are'), which replace the anticipated imperfect tenses, prompts the reader to visualise the scene in all its 
immediacy. After a short pause signalled by the ellipsis, the frame closes as the text returns to the preterite ('asked me'). For Reiter, such use of the historic present signifies 'an emotional use of tense; the witnesses are literally reliving the torments of their captivity' (2000: 153). In Langer's terminology, it might be suggested that the historic present marks a shift from 'common' to 'deep' memory (the scene surges up unbidden in the author's memory; the perfect 'has taken over' marks the hinge between two memories, two selves). Attempts to attribute intentionality - did Aylmer-Roubenne deliberately select the historic present for aesthetic effect, to lend authenticity to the event? or, indeed, to analyse the author's state of mind are, however, impracticable: only the moment of reception can be described with any degree of certainty.

In the next example, Maurice comments on the obduracy of the 'Bibelforscher' (Jehovah's Witnesses) in Ravensbrück:

Faced with this unshakeable obstinacy the guards had to load them onto carts on several occasions to take them to roll-call. It's as if I can still hear the shouts of the SS and the dull blows of the clubs raining down that macabre morning. They are throwing them out of the carts, letting their ferocious dogs loose on them, but they do not flinch and do not moan. These women, whose heroism borders on the superhuman, remind me of trees felled by the axe...

One day they decided [décidèrent: preterite] no longer to wear their assigned numbers.

(N.N., 1946: 50, my emphases, author's ellipsis)

This example can usefully be read alongside the extract from AylmerRoubenne. Here the compositional present ('It's as if I can hear') provides an explanation for the subsequent continuous presents ('raining down', 'are throwing', etc.) as the author states explicitly that she visualises the scene in the temporal 'now' of memory. As with Aylmer-Roubenne, an ellipsis seems to signal the fading out of the visual image (the passing from 'deep' to 'common' memory?), and the author 'snaps out of it' with a brisk return to the preterite ('decided'). Various time-scales seem once again to collapse: the phrase 'remind me of' is ambiguous, reading as either a compositional or a historic present (did Maurice compare the women to trees being felled while she observed them 'then', in the camp, or (and?) 'now' at the time of writing?).

The constant switching between past and present tenses - either compositional or historic - which characterises the majority of the 


\section{Textual identities II: textual constructs}

accounts gives rise to various potential effects. The historic present functions to promote a sense of immediacy. The blurring of temporal planes may be read as signalling the author's own loss of temporal coordinates, thus reinforcing a sense of authenticity: the author relives the past; she struggles to distance herself from certain events which surge up unbidden like cinematic images. Alternatively (and paradoxically) shifts between tenses may reveal the text as artifice, breaking the reader's 'suspension of disbelief'. ${ }^{25}$ When Maurice's N.N. moves from a section written in the preterite and imperfect ('Pangs of Hunger', 1946: 53-5) to a section which is written entirely in the present tense, the abrupt shift of tense jars, tending to be read as a device rather than an unconscious manifestation of the author's visualising of the past. A similar revelation of the text as artifice - or/and, once again, a signal that the author struggles to maintain a constant narrative thread as material crowds in on her - is prompted each time the compositional present intrudes upon the narration of past events. Lasnet de Lanty, for example, breaks off a sustained passage of present tense narration to intervene with a summarising reflection: 'On that first occasion I remained in Fresnes for two months' (1965: 25). Proleptic comments may disrupt the narrative in similar fashion. In Dufournier's account a passage narrated in the preterite recounting the deportees' arrival in the camp and the overcrowding which follows ('We learned that we had to spend the whole night in these conditions') is interrupted by the remark: 'Later we would realise what a privileged welcome we'd been granted.' A short proleptic passage describing the arrival of future convoys follows, succeeded by an abrupt return to the original scene: 'We were very thirsty, but the tap-water wasn't drinkable... Suddenly a siren sounded the alarm' (1945: 28-9). Passages narrated in the historic present are equally subject to anticipatory 'interruptions':

Clara's expression stops me short. She leans over:

'I think I'm going to die.'

But that's not how people die. (I've since collected information about other trains used to transport deportees ...).

At last, we're unloaded from the train.

(de Loulay 1945: 67)

The shift from past to present, narrative to commentary, may occur within two brief sentences - 'We're on the ramp at AuschwitzBirkenau. We don't yet know this' (Lévy-Osbert 1992: 96) - or appear in a totally different sequence of tenses: 'Staying still is tiring me out. (If I'd known how I'll miss this seat and this heat)' (de Loulay 1945: 
22-3). Here the historic present ('is tiring me out') not only gives way to an anticipatory interruption, it also carries over to 'contaminate' the following sequence of tenses as the future ('I'll miss') replaces the expected conditional tense ('I'd miss') after the imperfect tense. The substitution of the future for the conditional is not uncommon: 'Later, I found out that he reported that I was a "great lady"! God what politeness! What consideration! There will be a lot less of that in Ravensbrück!' (Saint-Clair 1945: 32, my emphases). Here the substitution of tenses ('will be' for 'would be') is more subtle, the narrative gliding from the imperfect to two atemporal phrases in which the verb is elided, before moving on to the future tenses. (The restoration of verbs - 'God how politely he treated me! How considerate he was' reveals the anticipated sequence of tenses more clearly.) Ironically - or paradoxically once again - the revelation of the text as artifice can function as a second-order authenticating process: artifice is employed, but it is employed precisely in order to represent the very real collision of time-scales experienced by the author as material is recalled and relived.

\section{Direct speech and the problem of tone}

On the whole, tense usage and fluctuation in the accounts need not be particularly obtrusive; they need not highlight the artifice of the text and the status of the deportee as writer. The same cannot always be said, however, of the use of direct speech, which is employed to varying degrees, and often extensively, in all of the accounts of whatever form (journal, texts adhering to the 'arrest-return' temporal span or those extending beyond it). Of course, the presence of this device, more associated with the creation of verisimilitude in the realist novel than with the non-fiction text, can easily be justified: the speech in question is not intended to represent verbatim recollections of conversations which took place months, or in some cases years, before, but typical exchanges which took place or might have taken place. Direct speech is used in order to render the atmosphere of the camps. As is the case with all literary devices deployed in the accounts, reception is key: the aim is to communicate the truth of the camps, and what is true ('vrai') to a certain extent inevitably equates in the reading act to what is plausible or believable ('vraisemblable'). The following discussion is consequently restricted to some of the potentially more obtrusive (and thus unsuccessful) uses of direct speech in the corpus, and to the related question of tone.

The first category of direct speech which may draw the critical attention of the reader comprises attempts - often rather poorly 


\section{Textual identities II: textual constructs}

wrought - to represent the pronunciation of non-French speakers or a non-standard register of French. Examples of the former include Wilborts's and Pagniez's respective attempts to mimic the speech patterns of German guards: 'Madam good morning, of me not the least fear you must have: the photographer I am' (1946: 72); “'eef you look out of zee vindow, or you try to communicate viz the outside vorld", he bellowed, "you vill be shot"' (1947: 24). More common are imitations of the speech of prisoners deemed to be of a low social class. In some cases a degree of reflexivity is evident in the representation of these speech patterns. Toulouse-Lautrec, for example, who introduces various speech types into the early stages of her account (recording the time she spent in various French prisons prior to deportation), inserts mock stage directions into her narrative and explicitly raises the issue of non-standard variation:

A voice: 'Madeleine's me name, Mado to those what's close friends, and I've been 'ere two months now. I'm thirty-three.'

Another voice: 'Give it a rest, you've been bashing our ears with that since you've been 'ere, I think we get the message. And any'ow, it's not "ere", it's "here"'. Laughter from Mado.

(1967: 29)

The introduction of a level of reflexivity by Toulouse-Lautrec paradoxically may actually increase verisimilitude. The very fact that the direct speech is flagged up explicitly establishes a point of contact between reader and author: direct speech may be a device, but it is a device used knowingly.

Examples of direct speech which may be adjudged to fail - where failure is equated with the (unreflexively) obtrusive - fall into various categories. Poor direct speech may result from a subordination of the function of characterisation to the desire strategically to convey information to the reader. In the following example the fellow-deportee to whom Saint-Clair attributes a lengthy speech serves as little more than a rather clumsy mouthpiece:

It was the last Sunday in July and while I strolled arm in arm with Colette I said to her:

'Tell me a bit about the camp.'

'Of course. I'm not sure of the precise surface area: sixty hectares, I think, but I know it was built on swamp and that it was the first prisoners who drained the site.' 
The passage continues at some considerable length. Failure in this case can be attributed to aesthetic shortcomings or 'invraisemblance': put simply, the reader in all likelihood simply does not believe that such a speech would have been uttered (far less recalled verbatim). The same criticism can be directed at the elevated lyricism attributed by Roux to a fellow-deportee who anticipates the difficulty of returning from the camps and the heights of acute experience which the deportees have attained:

'We'll make our way down safely, Cathy. Remember the climbers who come back from the great mountains? The lustre of the summits is on their cheeks, and, in their eyes, that light that you get as you draw closer to the sky. We'll make our way down safely, but once we're back on the plains, our cheeks will still be rosy and our eyes alight. I'm sure of that now, Cathy!'

(1946: 215)

Any speech which smacks of homily runs a similar risk. Brun describes the in-fighting which took place among different categories of prisoners held in jail prior to deportation. Having recorded her attempt to calm things down, she launches into a sermonising delivery: 'Not everyone is part of the Resistance ... what about all those people who, without engaging in open combat, help as best they can: the concierge who forgets having seen a Jew enter a tenant's flat' (1979: 103). Once more, excessive length does little to ease the passage of this harangue: the speech continues for some further 150 words.

Although the use of direct speech tends to exacerbate a negative reader response, the tone of the delivery alone may be sufficient to set readerly hackles rising. In the following example a patriotic and highly lyrical outburst may well smack of aesthetic failure. Dufournier records her response to the news that she is to be forced to work in a factory producing shells for the German army:

A revolt was building up within us; it stemmed from the very depths of our souls; it sprang forth from France, this land we bear within us, just as the flower bears its fruit, as the seed bears the golden wheat which ripples over our fertile plains. Should we scream our refusal in the face of the whole German nation? Alas! what use was our will, and what use our cries? 


\section{Textual identities II: textual constructs}

Although it is difficult to pinpoint precisely why this passage may trigger a response of unease (and while that response inevitably has a subjective component), the emotive tone may well have a part to play. As Young points out, and as the previous chapter suggested: 'The more dispassionate a text seems, the more rhetorically veracious or authentic it becomes' (1988: 164). More commonly, aesthetic inadequacy combines with what may be regarded as an inappropriate focus on the self. Heinemann observes that the use of dialogue in testimonial accounts is often associated with what she terms a 'self-dramatizing style' (1986: 124-5), while Ezrahi suggests that Holocaust literature is singularly unsuited to the heroic mode (1980: 69). ${ }^{26}$

An emphasis on the first person, and especially on 'heroic' acts, tends to be restricted to the early stages of the deportee account. Once the narrative progresses to a description of life in the camps, the focus shifts in most cases to a collective subject ('nous') and to collective struggles which occlude the individual. Authorial direct speech is, however, commonly found in the context of arrest and especially interrogation, and gives rise to numerous examples of potentially intrusive self-aggrandisement:

He [the policeman who has arrested the author] reads the letter and slides it back into the envelope, then stares at it.

'Well, either you're innocent or you're a very talented liar', he says.

'Take your pick, inspector', she replies, staring him in the face.

(Mori-Perrin 1992: 54)

Any hint of bravado or heroism, even in the relative absence of direct speech, runs the risk of distancing the reader. In the following example Wilborts (who like Mori-Perrin refers to herself extensively in the third person), reacts to the news that she is to be executed the following morning:

'Take her back to her cell.' As they cross the room something occurs to her. When she gets to the door, she says: 'Excuse me, what time will it be?' The reply comes: 'It's eleven o'clock.' 'But that's not what I'm asking you; I want to know what time I'll be shot tomorrow.' 'What did you say? What time? Five o'clock. Wait, come back here. Don't you understand that by baiting us like this you're only making things worse for yourself?' 'I don't see 
how I can make things worse for myself when I'm going to be shot tomorrow.'

(1946: 36-7)

While criticising the accounts on aesthetic grounds may seem a little mean-spirited - these are not, after all, for the most part at least, writers by trade - a great deal is potentially at stake, and that is the readers' willingness to accept that what they read is true. Although there is no reason to call the factual status of any of the above incidents into doubt, it nonetheless remains that what is perceived as inappropriate - whether that be due to misjudgements of tone or an over-emphasis on the self - can lead to readerly doubts. Wieviorka makes this point indirectly when she comes close to questioning the authenticity of one anonymous account - Birkenau: Bagne des femmes at least partly on the grounds just discussed: 'there is something disturbing about the anonymity of the text and a certain arrogance of tone, especially when the author describes her interrogation' (Wieviorka 1992: 468). ${ }^{27}$ Another account, Capitaine Simone's Moi, un cobaye (1975), may serve to illustrate this issue further.

Unlike the anonymous author taken to task by Wieviorka, 'Capitaine Simone' is identifiable - as Anne-Marguerite Dumilieu, whose name can be found on official deportation lists. The problem lies not so much in the content of the account, but in its delivery (though the two cannot necessarily be disentangled). A personal note should perhaps be introduced at this point: while reading this text, I found myself responding in a potentially inappropriate manner: not only did I begin to question the veracity of what I read; I also began to find the sheer accumulation of apparently outlandish detail positively laughable. This subjective response was then further complicated by a measure of guilt (there was no reason to doubt that such things happened) and fear (any reservations I might articulate could all too easily be seized upon by the wrong people and for the wrong reasons). What triggered this problematic set of responses?

In the first of several jarring episodes, 'Capitaine Simone' describes a female guard whose sexual pleasure required an attentive audience. We are informed, in a scene of mounting suspense - and here too the manipulation of the reader is somewhat obtrusive - of the manner in which a group of reluctant deportee 'voyeuses' was forced on a nightly basis to trek some three kilometres to a shower-block to attend the bizarre ritual: 'When they got there, she made them sit round in a circle, like at the circus, then gave herself over with a strapping young lad to the kind of goings-on that usually take place behind closed 


\section{Textual identities II: textual constructs}

doors' (1975: 163). The narration builds to a potentially laughable climax as we are informed that: 'This would have been a spectacle more ridiculous than shocking if we hadn't been naked' (ibid.: 164). Later in the account two further bizarre incidents are reported. The first tells us of a fellow-deportee who is dying as the camp is evacuated. Uttering her daughter's name in her last words, she grabs the unfortunate author's leg:

The dying woman's clenched fingers clasped me like a pair of pincers. I tried to jump out of the way, to get up. The fragile mortal remains of the skeletal old woman followed me. Dragging her behind me, I crawled towards the door. I felt I was losing my mind.

(ibid.: 185)

The scene concludes as the Russian soldiers perceive the author's dilemma and saw off the woman's arm. Ever since then, we learn, the sound of sawing triggers a paralysis in the author's left leg (ibid.: 191). The second incident occurs when the author returns home to discover that her partner has died, and makes her way to the site of the shooting: 'There was not much of him left: some gold crowns and his jaw-bone, traces of a cracked shin-bone, a splintered fragment of shoulder-blade. A specialist ... reconstructed his skeleton: 1 metre 86 centimetres, it was definitely Michel' (ibid.: 220). A military funeral takes place, but as the coffin is lowered into the ground, one of the bearers collapses, and the coffin plummets into the grave, closely followed by the author who attempts to reconstruct the fragmented skeleton (ibid.: 221-2). An important truth (re)emerges from this account. The deportees faced situations which were radically alien to the majority of their readers. The task of recounting these situations is fraught with risk: the deportee authors had to describe events which were by their very nature unbelievable, yet any excess or break from accepted boundaries of verisimilitude could threaten the channels of communication between reader and author.

\section{Apostrophe and pronouns}

Apostrophe, which may be defined as 'a sudden turn from the general audience to address a specific group or person or personified abstraction present or absent' appears in a variety of guises in the accounts. Patriotic addresses to France are not uncommon, and are often located at the start and close of the accounts, or, as in the following case, at 
moments which recall the deportees' country of origin with particular poignancy. Pagniez breaks off her description of a Sunday mass performed by the French using a makeshift altar erected against the backdrop of a French flag: 'France! Your emblem, made with love and ingenuity from our tattered dresses, made from our beggar's rags. Your three vibrant colours sing out against the wall, they make our hearts beat wildly, they make us weep' (1947: 111). This apostrophic interlude is typically characterised by exclamation ('France!'), and a shift to a higher register, marked by the presence of anaphora. More commonly, 'absent individuals' in the form of those who have lost their lives are addressed. Brun initially articulates the joy she felt when she found her mother in Ravensbrück: 'And you're there, close by yet so far away, forgetting everything I rush forward to join her' (1979: 136). The slippage from the second- to third-person pronoun ('you' to 'her') highlights a key trait of both apostrophe and second-person addresses: the expression of a powerful emotive charge, and an emphasis on the narrating subject (the 'you' form necessarily implicates the ' $I$ '). As we saw in the case of shifting tenses, the move here from the second- to third-person pronoun also highlights the collision of two time-scales: the author appears to drag herself from past to present, from the charged recollection of the highly subjective moment to a more measured, objective narration of events.

If family members form one group of designated addressees, then fellow-deportees constitute another. In an explicitly commemorative gesture, both Jeannin-Garreau and Maurel dedicate sections of their accounts to their comrades: 'O my dear friends, whom I left while you could still laugh, and who died a terrible death, I dedicate this chapter of my memories to you' (Jeannin-Garreau 1991: 57); 'Pani Irena, this chapter is for you' (Maurel 1957: 145). Wilborts's apostrophic enumeration constitutes a verbal memorial to those who were not to return:

My poor friends who were all there that night, where are you now? All dead: Denyse Clairouin, Mme de Ganay, la générale Audibert, Marion Cornier, Mme Bertulus, Maria Goedert, Mme Preud'homme, Mmes Guillon, Tilly, Cozanet, de Saint-Laurent, de Penguilly, de Ploec, etc... So many absences, so much suffering!

(1946: 130)

Often, the explicitly commemorative function seems to be tinged with a note of regret, even guilt. Touboul devotes an entire page of apostrophe to her friend Esther, insisting on the efforts made to keep her colleague alive: 'Poor Esther! Did we not do everything in our power 


\section{Textual identities II: textual constructs}

to encourage you, to help you?' (1982: 66). Heftler returns on two occasions to the death of fellow-deportee Estelle: 'I tried to support you the whole time we were together. But I wasn't strong enough to see it through right to the end' (1992: 117); 'Poor Estelle, you were a wonderful friend to me ... but I wasn't strong enough to keep you alive' (ibid.: 184-5).

In all of the above cases the primary function of the apostrophe (the expression of nationalism, sorrow, regret or guilt), masks a secondary effect: that of authentification. Apostrophe may be explicitly directed at a particular constituency ('a sudden turn from the general audience to address a specific group or person'), but the 'general audience' - in this case the reader - remains as the ultimate addressee. Addressing others who were present at the scene reinforces the authenticity of the account via the invocation of a community of witnesses, and simultaneously reminds those readers who were not present of the otherness of the experience undergone by those who were. This appeal to a communal memory may indeed be more explicit. Maous invokes the memory of a particularly vicious Polish Stubowa: 'My dear friends from Block 31, I'm sure that you can still picture her, just as I can...' (1996: 55); Jeannin-Garreau breaks off her narrative to appeal directly to a fellow-deportee: 'Do you remember, Renée?' (1991: 39).

Direct interpellation of a specific group may assume a different emotive tone, one of hostility and accusation. In at least some of these cases those who are addressed are unlikely to be part of the putative readership of the account, and the rhetorical move can be read as a means both to prompt the reader to judge those who stand accused and to highlight the affiliations of the author. Many authors interrupt their narrative to address the SS or others who are regarded as belonging to an antipathetic community. Wilborts singles out specific members of the SS: 'Oh! Binz, oh! Lehman and Binder, will you eventually pay for your crimes?' (1946: 101). Brun directs her invective at a broader constituency:

You monsters! What have you done? You sullied everything. To what depths did you try to make us to sink? May your punishment fit the horrors you perpetrated and may you be destroyed in turn; a curse on you, and may our German comrades who have suffered alongside us for so many years take your place and build a decent Germany worthy of respect. 
Collaborators (who may potentially be readers of the text) are also targets for invective: 'You collaborators who accepted defeat so easily, who trembled for your lives and your possessions; you who cowered under the boot, worthy servants of your master, the man of Montoire' (Wilborts 1946: 63). Addressees may encompass a broader audience. Simier, for example, apostrophises a French audience who lived through the occupation years: 'You can judge for yourselves how we were fed, you who probably complained during the war that your bread ration was inadequate, or that there wasn't enough butter' (1992: 31).

In other cases the addressee is unspecified, and the force of the rhetoric varies in intensity. The second-person plural pronoun may be used to strengthen communication by introducing an informal oral register: 'Don't think that we had arrived at last' (Simier 1992: 19); 'We're in high spirits, I can assure you' (de Loulay 1945: 146); 'I introduce you to ...' (Roux 1946: 37); 'Look at them' (ibid.: 182). The impact of such formulations can be increased by explicitly designating the reader. Huk recounts her move to a more hygienic jail: 'Reader, don't be deceived. Comfort comes at a high price, as we'll see' (1958: 63). Distance and complicity come together here as Huk adopts the role of 'roving reporter' or guide: the 'we' invites complicity, but the pre-emptive formulation 'don't be deceived' reminds the reader of the gap which separates the reader's world from that of the deportees. The rhetorical stakes may be further raised when phrases pre-empting the reader's response are coupled with rhetorical questions: 'you seem disgusted? What would you have done?' (Toulouse-Lautrec 1967: 222). Imperatives have a similar force: 'We remained shut away like this without air, light or water in the over-heated carriages until... listen carefully... the Friday morning' (Simier 1992: 19); 'Try for one second to picture the atmosphere' (Mallet 1949: 54). The use of the second-person pronoun in the last two cases serves once more to highlight the gap between the reader's world and that of the deportees: though we are invited to picture the scene, it is unlikely that we are able to do so. Schapira uses a similar device: 'Can you imagine what the endless roll-calls were like for people who were already weak, under-nourished, who were coming back from work details in the rain and the wind and the cold?' (1994: 64), as does Tichauer, with considerable impact: 'Have you ever heard someone screaming for their life?' (1988: 84).

As we have seen, apostrophe and second-person pronouns can both invite complicity and highlight difference and distance; groups of readers may be prompted to address their own epistemological and 


\section{Textual identities II: textual constructs}

ethical communities: we are variously invited to judge, sympathise, and attempt to empathise with a radically 'other' experience. But what of the deportees themselves and the groups they comprise? In the preceding chapter it was suggested that in the later stages of the accounts the deportees' own identity was eclipsed by their sense of belonging to a wider community, an issue which is articulated in the Preface to Dufournier La Maison des mortes. The response to the question 'does anyone ever come back from the house of the dead?' is explicitly framed in terms of pronoun usage: 'Your account reveals that there are two answers. One is expressed in the first person singular, and the other in the first person plural' (1992: 10). Whereas the firstperson singular form designates the returned self, we are told:

that the 'we' becomes part of you, that each one of your friends, whether dead or alive, is your Siamese twin, that together you all form not merely a group whose bonds cannot be weakened by either time nor distance, but a collective being, kept alive by the beating of a single heart.

(ibid.: 10)

But this reply masks an important truth: the first-person plural pronoun in the accounts in fact designates a range of groupings or communities, and the inclusion of some is always based on the exclusion of others. The 'we' may designate all the deportees, in which case the group identity is usually constructed in opposition to the SS or to those who did not experience the camps. Dufournier, for example, highlights the use of pronouns when she describes the gap between 'them' (those not deported) and 'us':

As for them, they had no idea what we were ...

'They' ask us:

'Did you suffer a lot?'

'No, it was bearable.'

A gulf has already opened up between us. How can we explain; what's the point? 'They' say:

'We've thought about you so much.'

(ibid.: 157)

More often, however, the first-person plural designates a more restricted group, and more exclusive allegiances. 'We' may be not just 'French deportees', but a particular sub-section of French deportees. Brun, for instance, employs the first-person plural to designate a group 
comprising not merely French political deportees, but a small collective of Parisians ('we, the four Parisians', 1979: 70). And not just Parisian political deportees, but young ones. Brun points out that while the older, married deportees ('they') arrived in Ravensbrück looking defeated and haggard, 'We youngsters, all about twenty years old, are made of sterner stuff' (ibid.: 134). Francine Christophe reveals similarly 'ageist' sympathies: 'The deportees are getting thinner and thinner, they drag themselves to the toilets. We, the children, hang around the trenches and count how many of them have got piles' (1996: 84).

Groups may be less readily identified (with). Abadi, who worked as a doctor in Auschwitz, begins her description with an 'outside' view, before identifying with her fellow-workers:

Each morning, as soon as the work details have finished filing along the Lagerstrasse, the doctors leave the block where they sleep and go to the one they work in. Once there, we carry out examinations, treat patients, give injections, and keep our patients company.

(1995: 51, my emphases)

Abadi's account also switches on occasion between the first-person plural pronoun and the impersonal 'one [on]'. According to Pollak, the former designates 'a collective capacity (assumed or real) for action and agency', while the latter is used to designate 'temporary groupings comprising individuals with little agency who have not joined the group by choice' (1990: 239). ${ }^{28}$ In the following example the switch from 'we' to the impersonal is particularly striking:

We've just settled down when someone shouts: 'Get down!' We jump down: we've already learned to obey orders fast, and all of us several thousand women - are crammed together in the empty space. ... A mass of bodies swaying [On tangue], one way then the other [on revient, on repart]. Nausea [On a mal au cour]. Exhaustion [On est trop fatiguées]. Some exchange insults, others, very pale, grit their teeth, some cry quietly. ... The movement continues, for what feels like hours, until, completely exhausted, we're finally allowed to get back in our bunks.

(Abadi 1995: 30, my emphases)

Use of the impersonal in this case both bears out Pollak's analysis - the pronoun is employed in the context of a description of enforced 


\section{Textual identities II: textual constructs}

passivity - and conveys the impression of an undifferentiated mass. In certain situations differences becomes irrelevant; in the face of overwhelming force all deportees are reduced to a common denominator.

\section{Humour and irony}

Preceding analyses of stylistic and rhetorical textual characteristics have revealed a variety of means whereby readerly responses can be manipulated, or, to use a less intention-oriented term, affected. Humour and irony differ in one key respect from these traits. Both rely heavily on a potential community of understanding between author and reader in order to function: humour depends on the reader's capacity to 'get the joke'; irony, as a non-literal mode, requires the reader to decode the unspoken message. When and if these conditions are met, a powerful bond based on what remains unsaid is created, and communication is intensified.

Reiter describes humour as 'principally an immediate reaction of prisoners to a particular experience' whereas 'irony, as a linguistic phenomenon, belongs at the level of reflexion and literary composition' (2000: 124). Rather than differentiate between a post-factum writerly phenomenon (irony) and humorous events or comments made within the camps - a distinction which is, in fact, rather less straightforward than Reiter suggests - it may be more useful to consider both irony and humour in terms of degrees of reflexivity or 'flagging up' for the reader. In some cases, the humorous interlude or ironic jibe may be clearly signalled or commented upon, while in others, we are left to our own devices. The communicative function of both modes is stronger in the latter case.

Reflexive comments relating to both humour and irony are common in the accounts. In such cases the authors both refer explicitly to the mode in question and signal its intended function within the context of the deportee situation. Lasnet de Lanty, for instance, uses humour to alleviate the tension and ill-temper generated by overcrowding as the prisoners begin their long journey to Ravensbrück:

Something had to be done: I leaned towards my friend who was standing in front of me and asked her disingenuously, as if we were in the metro at rush-hour:

'Are you getting off at the next stop?'

Laughter all round. 
Based on incongruity as humour often is (likening the often fatal journey in cattle-trucks to the metro), this typical example indicates a break from enforced passivity - the deportees fight back the only way they can, deploying mental, verbal resources - and the reinforcement of group solidarity. Communication with the reader is not necessarily strengthened. The signal 'Laughter all round' may weaken the potential bond based on what remains unsaid: we are not left to 'get it' but told that there is something to 'get'. Paradoxically the commonplace vehicle (in both senses of the word) for the humour - the metro - both facilitates our understanding and detracts from the brute reality of the situation. Lasnet de Lanty's humorous comment is made en route to Ravensbrück and in most cases examples of this sort arise early on in the accounts. Defensive humour may triumph in some circumstances, but as conditions worsen it becomes increasingly harder to sustain, as Améry points out: 'Day four. Hunger, cold, stench, exhaustion. Socalled "defensive" humour is on the wane' (1945: 141). Lévy-Osbert, similarly, suggests that irony, like humour, flourished best while spirits remained high:

We're travelling by bus. We're really getting quite used to it. Somewhat sarcastically we insist that we've never travelled in such comfort before.

I am ironic, we are ironic, you are ironic.

When the journey's over it won't seem quite so funny.

If humour in the early stages of imprisonment functioned primarily to bolster spirits and generate solidarity, the later stages of the accounts are characterised by examples of humour and irony which are both left to the reader's decoding, and directed at a different target: the SS. Lasnet de Lanty, for example, comments wryly on the endless roll-calls, taking the opportunity to deride the famed German efficiency: 'I must say arithmetic is really not the Germans' strong point!' (1965: 147). Toulouse-Lautrec focuses on the same target, combining the aggressive attack with a degree of self-deprecation:

Discipline in the great Reich extends to bladders. The official evacuation times are nine o'clock and four o'clock. Given that the toilets are five hundred metres from the kitchens, the situation is somewhat critical for unpredictable bladders like ours.

(1967: 232-3) 


\section{Textual identities II: textual constructs}

In all these cases a lack of power is countered by limited resources, and the reader's reaction may be somewhat ambivalent, admiration at the spirit shown combining with an acute awareness of the hopelessness of the situation. Roux's description of the French deportees' small-scale rebellion is both humorous and poignant:

Another roll-call. The commandant's words, even more severe than last time, are translated for us: while a love of music is only human, if we really want to sing, we must sing in German.

'Ja! Understood!' we reply, even more submissively.

And we set off down the road singing the same songs, enunciating clearly:

'Ja, ja, ja, ja, ja, ja!'

But we have the perfect excuse, we tell our stunned guards as sweetly as possible: that's the only German we know.

(1946: 118)

Mori-Perrin records a similarly gritty response to the dreaded "Sheisskolonne" work-detail:

The 'Souris' sneers at us. She's thrilled that she's making us - the filthy 'frenchies' - do this revolting job. At that point our friend Nicole cries out:

'Come on girls, all together now, Let's shovel shit / and shovel it with glee', etc....

(1992: 131-2)

Ironic comments assume the same anti-authority line, and vary little in scope and form from account to account: "You madame, shut it! Speaking no allowed!" How very delightful these Germans are!' (de Lanty 1965: 18); 'giving orders in such a typically gentle German way' (Lorge 1992: 12, referring to the factory overseers); 'This punishment [25 or 50 lashes] was administered with all the solicitude we've come to expect of the Germans' (Simier 1992: 37).

When derisive comments are not directed at the SS or other figures of authority, they most commonly take the form of black or gallows humour, ${ }^{29}$ typified by Wilborts's reaction to being informed she is condemned to death on three counts: 'She wonders how they'll go about executing her three times. Hang her first, and the rope breaks, then shoot her, and miss, then behead her. Losing her head, literally, now that really would be most unpleasant!' (1946: 85). 
Ironic barbs may be equally dark. Abadi records the response of fellow-doctor Annie who is instructed by SS officer Klein to look after her patients properly as the Allied front advances and Auschwitz is to be evacuated:

With an inspired expression she rushes towards Flora, grabs her wrist and shakes it as hard as she can: 'I've been deeply touched by our dear Klein's words. Wait, I'll take your pulse... How's your grandfather? He was shot in the Ghetto? Excellent. And your parents? Gassed as soon as they arrived in Birkenau? And your children too? Excellent, wonderful. What about you? You're starving, dying of thirst - you've got typhus, your heart's giving out, your legs are swollen and there are one or two other little complications?'

(1995: 150)

Examples such as these may teeter on the threshold of the functional or acceptable. What are we to make, for instance, of Dufournier's reference to the building of a gas chamber at Ravensbrück as 'the latest luxury in the development of the camp' (1945: 179)? But if we reject such comments as 'sick', then we inevitably do so with reservations: who, after all, are we to judge? Black humour works to the extent that is shows us, once more, the gap between our comfortable world and one in which humour and irony - however black - were crucial tools of survival and rebellion. Even so, the deportees themselves had their limits, as Birnbaum's attempt at gallows humour when a selection is announced reveals:

I try to be light-hearted: 'What's up with you lot? What a load of misery-guts, what a bunch of cowards! Come on, pull yourselves together, and if we do end up in the ovens, well, too bad! Just think of the lovely soap and sausage we'll provide for our friends! Don't you fancy being made into a nice rich chunk of red pudding, or a slice of lovely pink paté?' But it's not quite the right time for humour and nobody's in the mood, including me.

(1946: 69)

The potential communicative pact between reader and author may break down for different reasons: we may detect unintentional irony, or may be unsure whether a comment is intended as ironic or not. When Dufournier describes her arrival in Ravensbrück and the gross overcrowding of deportees in a single hut, her reference to asphyxiation seems innocent enough, but connotations of the gas chamber introduce 


\section{Textual identities II: textual constructs}

an (unintended) note of irony: 'We found out that we were to spend the whole night in these conditions. We looked at each other in amazement. Were they trying to asphyxiate us?' (1945: 28). Maurice's reference to the fate of the Jews and depiction of France as 'a country where they have their own home' (1946: 27) is similarly ironic in the face of the large-scale appropriation of Jewish property which came to light after the Liberation.

The extreme situation of the camps is such that the literal and nonliteral often threaten to merge. The following typical examples may be read either 'straight' or as ironic comments (or indeed both): 'It was a Lager like any other. Only one difference: since 1944 babies were no longer drowned at birth; they were left to starve to death. I was lucky!' (Aylmer-Roubenne 1996: 40); 'Not everyone has had the chance to find themselves condemned to death. It puts you in a quite unusual state of mind' (Heftler 1992: 100). The ambiguous nature of such statements, the literalisation of the non-literal, is symptomatic of a world in which the normal rules and parameters no longer apply. As we shall see, a similar breakdown of the figurative and the literal occurs in the context of the next area for analysis, that of metaphor.

\section{What it was like: metaphors and intertextual allusions}

\footnotetext{
Was it 'like a red-hot iron in my shoulders' and was this 'like a blunt wooden stake driven into the back of my head?' - a simile would only stand for something else, and in the end we would be led around by the nose in a hopeless carousel of comparisons. Pain was what it was. There's nothing further to say about it. ${ }^{30}$
}

Of all the structural and stylistic features considered thus far, metaphors (the term will be used here to embrace all modes of analogy and comparison) and intertextual allusions perhaps most clearly illustrate the problem of communicating a radically 'other' experience. As the above words of Jean Améry indicate, the use of these devices is not, of course, without its problems. If, as he suggests, certain experiences lie beyond the reach of analogy, if the world of the camps is truly incommensurate with known parameters, then a prose style denuded of images, comparison, and abstraction might be considered to be the only way forward. ${ }^{31}$ Although some accounts do on occasion reveal an awareness of the limits of analogy and intertextual allusion, if only in specific contexts, the corpus of texts is replete with metaphor and, to a much lesser extent, intertextual allusion, for the most part used uncrit- 
ically. ${ }^{32}$ The following section will be limited to a critical examination of certain recurring groupings of each.

A number of deportees liken the routine and strict hierarchy of the camps to life in the midst of a religious sect or cult. Brun, for instance, describes SS head overseer Dorothea Binz as 'the high priestess of the camp' (1979: 141), de Gaulle-Anthonioz refers to the deportees as 'initiates' (1998: 49), while Dufournier depicts the daily roll-call as a 'ritual' (1945: 51). More common, however, is the attempt to integrate the ordeal of camp life into a paradigm of Christian persecution and suffering. Simier, who refers here to the holding of a mass at Romainville, focuses on the former: 'The mass held in the depths of a vaulted blockhouse brought together a large, contemplative audience which reminded me of the catacombs in the days of Roman persecutions' (1992: 16). Louria (a Jew) opts for an Old Testament comparison: she and her friend, both facing a selection, are likened to 'two lambs offered up in sacrifice [en holocauste]' (1979: 188). Birnbaum (also Jewish) ironically designates the Jewish deportees, marked out by a large cross painted on their clothing: 'Jew, it's your turn to carry the cross' (1946: 19), an analogy taken up several other authors: 'We cry out like Christ on the crucifix' (de Gaulle-Anthonioz 1998: 13); 'The crucifixion, after the fourteen stations of the cross' (Friang 1997: 172, referring to the deportees' march out from camp). For others, suffering is framed in terms of heaven and hell, the damned and the saved: 'Having doubtless atoned for all my sins in Germany, I travelled via Purgatory not to say Hell, from which no one, in theory, returns, and finally arrived in Sweden: paradise' (Felloni 1946: 13); 'roll-call the following morning and the chosen few (excuse the expression) have to leave the block' (Lorge 1992: 9).

Allusions to the hell that was the camps are commonly articulated in terms of the most common of intertextual references: Dante's Inferno, described by Wieviorka as 'the only allusion, and one which is widespread' (1989: 28). Although, as Ezrahi points out, very few Jews would have seen the entry gate to Auschwitz with its infamous slogan 'Arbeit macht frei', 'our memory clings to the inscription above the gate as the modern version of Dante's Lasciate ogni Speranza ... at the entrance of his inferno' (1996: 126-7). The link certainly existed in the minds of several deportees, and not just in the context of Auschwitz: "The entrance to Ravensbrück could have been inscribed with the words: "Abandon hope all ye who enter here"' (de Lanty 1965: 131); 'Alas! Experience has taught us that beneath each circle of the hell we are in yet lies yet another circle, plunging into ever greater depths of horror' (Pagniez, 1947: 121, also referring to Ravensbrück). 


\section{Textual identities II: textual constructs}

For others, comparison is more nuanced. Huk, for instance, opts for a optimistic version: 'Don't give up hope, you who enter here. You will survive and find your way out' (1958: 126). Birnbaum, referring to a selection in Auschwitz, suggests that Dante's vision is an inadequate analogy: 'I will never ever forget those hours, or the screams I heard, or the blows which silenced the women. Dante had not foreseen such sights; his hell was mild indeed compared to this one' (1946: 75-6).

An awareness of inadequacies of the Dante intertext is signalled in this case, but for the most part the deportees are not so critical, although both references to Dante and metaphors invoking a Christian paradigm have their shortcomings, as Langer points out with respect to the former:

In fact, Hitler's victims have nothing to do with Dante's damned, precisely because of the total absence of 'expected logic' in their fate. The damned - it is almost too obvious to repeat - suffer the consequences of their sinful actions; cause and effect rule their destiny.

(Langer 1982: 11$)^{33}$

Whereas analogies drawn from religion emphasise meaning and continuity, the majority of metaphors employed highlight rather the radical discontinuity of the world of the concentration camps. The next grouping of metaphors introduces images from quotidian life before the camps, and serve to underline the brutal juxtaposition of two disparate worlds. Examples in this category include the apparently unlikely evocation of school-days. Heftler refers to her first experience in a work detail: 'I feel a bit like the "new girl" who has just spent the night with the other boarders and is worrying about the first class' (1992: 57). Marching out the camp, the deportees line up 'two by two, just like at boarding-school' (de Lanty 1965: 220). Authorial intention cannot be ascertained, but in terms of reception, it can be suggested that the incongruity of tenor and vehicle is either unfortunate (boarding school discipline can hardly be compared to the rigours of a concentration camp) or highly successful, highlighting the distance travelled from the world 'before'.

Although analogies drawn from the 'ordinary world' outwith the universe of the camps are plentiful, some are inevitably more striking than others, though all have the undoubted advantage of employing a vehicle which evokes a world familiar to the reader. Novac's description of a guard's heightened state of animation prior to hitting prisoners is certainly incongruous: 'She's all fired up by the experience, 
like a tennis player who finally throws herself into the match after careful hours of training' (1996: 13-14), as is Pagniez's reference to leaving Constance prison: 'Is it chivalry which dictates that I'm left with my hands free rather than tied to my colleague like a couple of pampered poodles on a leash' (Pagniez, 1950: 10). Améry's choice is less original, but nonetheless disturbing:

The next day the dead are counted again on the Lagerstrasse, in front of the crematorium, while the oven attendants ... casually and nonchalantly unload a cart-load of several hundred bodies. The corpses, skeletons wrapped in folds of skin, fall into the mud with the dull thud of bundles of wet washing.

(1945: 157)

The (potential) force of metaphors drawn from 'ordinary life' lies in their highlighting of the gap between two worlds. Another set of recurring images makes this point more explicitly, by means of references to a metaphorical break or chasm between the universe of the camps and that of those left behind: 'We were no longer in the world of the living. A fault-line separated us from those who led normal lives' (Asseo 1974: 79); 'An impassible gulf separated our two worlds' (Touboul 1982: 190). The notion of two distinct worlds is often expanded, with the introduction of metaphors relating to extra-terrestrials, new species and planets: 'We came from another planet' (Maurice 1990: 129); 'Sometimes we feel as if we're in another world, a different planet which is not Earth' (Saint-Clair 1945: 121). Roux, in a variant on the theme, brings together the image of an alien world and a Jewish stereotype (she is not Jewish herself): 'You've lived far away in a world which wasn't Earth, and you'll never be a part of those who live on Earth again ... You'll always remain on the margins. Remember the Wandering Jew, my girl, remember' (1946: 220-1). Novac inverts the image of the camp as alien planet when she describes a newly-arrived convoy of Greeks, who are wholly oblivious to what awaits them: 'I found myself amidst a crowd of people who'd landed from another planet' (1996: 226). When she and her colleagues find a scrap of mirror, the reflection that faces them seems barely human: 'These women don't look like tramps any more, nor like vagrants. It's as if a whole tribe of extra-terrestrials had disguised themselves as human beings' (ibid.: 268).

Another widely used metaphor compares the deportees to puppets or automata (interestingly, the controlling agent who pulls the strings is never mentioned; it is the uncanny sight of the deportees - passive 


\section{Textual identities II: textual constructs}

yet active, living dead - which is conveyed). ${ }^{34}$ Images of bestiality are equally prevalent, and are in nearly all cases used to designate not the SS but the deportees themselves. These range from clichéd references to living conditions - Wilborts refers to 'the terrible stench of a neglected pigsty' in the context of a housing Block in Ravensbrück (1946: 98) - to images which emphasise attitudes of the SS. The returning work details remind Elina of 'a huge human cattle-market' (1982: 11); Fénelon, working in the orchestra, wonders if the camp commandant actually listens to them play: 'Is he aware of our existence? Of course not: lice are only there to be exterminated' (1976: 147).

The designation in the last example, is, one assumes, an ironic echo of SS attitudes rather than an internalisation of the latter's views. Many images, however, do have an edge of self-criticism. The deportees are all too aware that conditions have robbed them of many basic human traits. The desperate reaction to the possibility of extra food or clothing is a common topos: 'When one of us died the rest, like a flock of crows, would swoop down to fight over what little she had left behind' (Elina 1982: 27). Abadi's description of the sight which met the liberating English soldiers at Bergen-Belsen is damning: 'they feel as if they're in charge of a zoo full of savage creatures, with some dominant species and a whole mass of moribund ones, an ante-diluvian zoo where it's as natural to dominate others as it is to die' (1995: 158). Although images of bestiality are most commonly used in this self-critical style, a more combative line may be adopted. Christophe's biting irony mitigates the sense of resignation found in many self-critical images:

Flocks of sheep in the fields frolic. Herds of cows, wandering along country lanes, stop to snatch a mouthful of grass. Herds of Jewish children, in the camps, no longer have a soul. They walk straight ahead, their eyes unfocused, slowly, already dead.

(F. Christophe 1996: 35)

Friang also adopts an altogether feistier tone when she lines up with her fellow-deportees to be selected for factory work:

I expected them at any moment to feel our withers and run a hand over our flanks. Luckily they'd forgotten to fill their pockets with lumps of sugar or carrots. Some of the women would doubtless have accepted them with a satisfied whinny.

(Friang 1997: 150) 
Perhaps the most powerful, and disturbing images are those which liken the deportees not merely to animals, but to regressive, almost entropic forms. Pagniez describe the scene in a block in Ravensbrück just before morning roll-call:

The formless mass writhes in the dark, distorted, all its joints creaking. Emerging shapes moan and stir in the plasma in which they had been submerged; black things rise up on all sides, clash, shout out in anger and pain. ... Hurrying, bodies collide violently. A quadruped heaves its way across your stomach; a heavy reptile slithers over your feet.

(1947: 42-3)

Metaphors relating to bestiality, inanimate objects and alien worlds emphasise the 'otherness' of the camps, and the potential consequences of living in such a world. The next two groupings stress another, related, aspect of the concentration camp experience: the sense of utter un-reality or de-realisation which struck the deportees as they entered and participated in this alien universe. The first of these groups which is by far the largest of all the categories - comprises analogies which derive from the world of art. Although Reiter judges such metaphors as potentially 'inappropriate' (2000: 104) - representational forms, after all, should not be confused with real life - these metaphors are used precisely to underline the enormity of the reality which the deportees experienced. Once more, paradox is at work. As critics have pointed out, metaphors run the risk of screening reality, masking the truth of events which may already appear to be legendary, apocryphal in their sheer excess and otherness. Although images drawn from the world of art might be deemed to be especially open to such a risk, the deportees turned to the representation of fictional worlds precisely in order to convey the un-reality of the reality which they encountered.

Images of de-realisation drawn from the realm of art cluster especially around accounts of the early stages of the deportees' experiences, for example arrest and interrogation. Birnbaum's interrogation assumes a similar air of unreality; those involved seem to be actors in a drama in which she finds herself caught up: the interpreter is like an actor playing a role'; the scene is described in terms of staged 'dialogue' complete with a 'coup de théâtre' (1946: 24). Descriptions of the deportees' arrival in the camps are commonly couched in terms of the breaching of a frontier between reality and unreality. Maurice explains the sense of detachment which seized her upon her arrival in Ravensbrück: 'a sort of splitting occurred, and I found myself 


\section{Textual identities II: textual constructs}

comparing the sight before me to a stage set, a kind of huge panorama which horrified and amazed me' (1993: 27). Birnbaum uses similar figurative language to describe her arrival in Auschwitz: 'No director could ever convey the impact of our arrival. It's dark, it's freezing cold, a dry, biting sort of cold. Powerful spotlights pick out the train and the railway line in a bright, white light' (1946: 16). Although such images usually cluster around depictions of the first moments in the camps, other extreme situations prompt similar analogies. Lesèvre describes her first sight of deportees lined up for work details:

I watched without understanding, never for one moment thinking that we would soon be a part of that tragic procession. No. I looked on in a hallucinatory state, as if I were the spectator of a strange, terrifying film. I wanted it to stop.

Specific cinematic genres may be evoked, as is the case when de Loulay describes the cattle-trucks in which the deportees are massed: 'It's a scene straight out of an American action movie' (1945: 27). Abadi describes a prisoner overseer in different terms: 'She seems to have stepped out of a bad realist film' (1995: 21), while yet another genre is evoked by Améry when she narrates her arrival in Ravensbrück: 'The Siberian pine forest that we've just crossed suddenly reminded me of an old anti-Soviet propaganda film' (1945: 22). Both the 'thriller' and the horror ' $\mathrm{B}$ ' movie are evoked in other contexts.

Various other representational forms are also commonly invoked. Lorge, for instance, draws her analogy from the world of the circus: 'Suddenly, just as darkness was lifting, there was a blinding light (the Krauts love this sort of staging), like a circus entrance lit up by acetylene lamps: there was the camp' (1992: 5). Crémieux's comparison of the violence of the SS - 'The combination of codified ritual and violence, the precision of movement, of tone of voice' (1999: 51) - to Japanese Nô plays is particularly apposite. For many deportees, the situations in which they found themselves were so 'unreal' as to evoke the realm of fiction. Brun, on the point of arrest, wonders if she can save her parents from a similar fate: 'Without acting like some heroine out of a novel I thought I could maybe save the situation by accusing myself' (1979: 14). The fairy tale is invoked as often as the novel. Huk's first sight of Ravensbrück has something of the ogre's lair about it: 'The walls of the fortress rise up before us, a crushing monster grinding its teeth and staring at us, a mysterious rampart whose secret we cannot penetrate.' The huge doors close behind the deportees as in 
'a tale of the supernatural'; 'We almost expect to hear the mournful laughter of some invisible magician' (Huk 1958: 127). For many deportees it is the moment of liberation which seems like the longedfor but 'unreal' 'happy ending':

After several weeks the slow progress of the advancing Allied forces disappointed us more than a defeat. We felt this way because of our need for compensation and because for us deliverance was a fairy-tale, and we thought things should happen as they do in novels.

(Lahaye 1983: 52)

Familiar tales may be given an unusual twist. For Roux, the story of Tom Thumb is used merely to convey a sense of fear as the deportees leave Ravensbrück for the unknown territory of Holleischen camp: 'Farewell my little ones, farewell! I'm leaving... The ogre which awaits us, we lost Tom Thumbs, has long teeth and a ravenous appetite' (1946: 76). Both Friang and Christophe, however, have a more macabre take on the fairy-tale, referring in both of the following examples to the bodies of those who collapsed and died (or were shot) in the course of the evacuation of the camps: 'From this point on, all along the roads and paths, we marked off our route like macabre Tom Thumbs' (Friang 1997: 186); 'I'm reminded of Tom Thumb who left a trail of stones; we leave a trail of bodies' (F. Christophe 1996: 118). In some cases the images seem particularly incongruous: 'Within thirty seconds, under the supervision of an Aufseherin, twenty deportees strip you completely, with all the dexterity of the dressers at the FoliesBergères' (Améry 1945: 24); 'Honestly, these Romans are crazy' (Brun 1979: 224, upon being ordered to gather up shoes of the dead; the allusion is to Astérix et Obélix).

Metaphors drawn from four other sources recur repeatedly throughout the corpus: the 'Grand Guignol', the 'dance of death', the 'Cour des miracles', and the 'mascarade'. Lesèvre, for example, describes her short stay in Neuebremm camp, where the female deportees were forced to watch the male prisoners undergo repeated humiliation and physical brutalities: 'the most refined forms of torture were followed by terrible physical abuse. For us, the torture consisted in having to watch this Grand Guignol' (1987: 83). Founded in Paris in 1897, the Grand Guignol theatre was famed for its staging of gruesome scenes; murder, rape and mutilation were the staple fare, and the theatre was known for its particularly gory special effects (fresh blood and animal carcasses were supplied daily by local butchers). 


\section{Textual identities II: textual constructs}

Interestingly, the theatre was also known for its amoral representations: the guilty were rarely punished. Lesèvre's suggestion that the true 'torture' lay in forcing the female deportees to watch, however, represents an (unintentional?) twist on the original: the Grand Guignol was particularly popular with women, especially those from the higher echelons of society.

If images of the Grand Guignol evoke violence and amorality, allusions to the 'dance of death' serve to underline the inescapable presence of death in the camps. Abadi, for instance, refers to a selection in Auschwitz: 'A body steps forward, then another body... It's a sort of "dance of death": two steps forward one step back' (1995: 65), while Fénelon, in Bergen Belsen close to the moment of liberation, uses the image primarily to refer to her wasted physical state: 'I have to look after my hands so I can play the piano. Play the piano... What a joke. These knucklebones hanging at the end of my hands are only good for banging out The Dance of Deatb' (1976: 13). Although in most cases the image of the 'dance of death' serves merely as a shorthand for death, in fact, the choice is in some respects particularly appropriate: the original representation is thought to have been a fresco in the Paris Cimetière des Innocents (executed between 1424 and 1425); in its various forms (visual, musical, etc.) the allegory represents the notion that death knows no boundaries of rank or class, and represents the living drawn unwillingly to their end. In one other respect, however, the image is less apposite: as used by the Christian Church, the dance of death served as a form of morality play, reminding the viewers to lead a Christian life and repent of their sins in preparation for death. As was the case with Dante's Inferno, the suggestion of divine retribution for sins committed is hardly consistent with the reality of the Nazi regime.

The 'Cour des miracles', featuring perhaps most famously in Hugo's Notre Dame de Paris, a district in Paris (and other major cities) which harboured the outcasts of society (thieves, beggars, gypsies) is used in the accounts to describe a variety of scenes: the camp hospital (le Guillerme 1946: 119); arrival in Ravensbrück (Maurice 1993, 27); the camp morgue (Maurice 1946: 23); thieving among the deportees (Brun 1979: 224-5); the chaos of bodies (Pagniez 1947: 82); 'the knitting detail' (Améry 1945: 42). In all cases the image is deployed somewhat loosely to suggest chaos, and mix of individuals in a state of physical degradation. The same rather loose usage is made of the 'mascarade', employed in many of the accounts to evoke the often extravagant clothing distributed to the deportees. 
For most part, as we have seen, generic forms are most often used in metaphorical formulations, but in some cases the deportees are more precise. Specific artists and films may be singled out: Pagniez compares the horrors of the cattle-trucks to Brueghel's hellish images (1947: 37); Elina describes the misery of the camp hospital in terms of El Greco's tragic images (1982: 23). The same artist is selected by Améry, who describes the dismal scene of rain washing over Ravensbrück: 'Set against a backdrop worth of El Greco, peopled by characters who also seem to come straight from his palette or a scene from the Inquisition, the white stripes of the dresses and the windows stand out clearly' (1945: 43). As with all metaphors and intertextual allusions, some may be deemed to be more apt than others. Readers may, for instance, question the felicity of two films which are cited on several occasions: Les Temps modernes (1936), starring Chaplin, and Metropolis (1927). Certainly the former may be considered appropriate to the extent that it is used to described the repetitive factory work carried out by the deportees. The film's focus on hunger may also be regarded as apt, though slapstick scenes involving food in the film may jar somewhat with the slow starvation of the camps. The film's opening shots, cross-cutting between a flock of sheep and workers heading en masse to work, may successfully convey the sense of passivity and bestiality already discussed above, but frequent anti-Semitic references to the Jews going to their death 'like sheep' (a connotation which would not necessarily exist when the deportees were writing), introduces an uncomfortable note. Finally, the allusion to Chaplin himself, a Jew and a Communist (who famously starred as Hitler in The Great Dictator, 1940), may carry with it an (unintended?) degree of irony. Similar issues arise with respect to Metropolis. As an early example of science fiction, the film fits in well with the metaphors of extra-terrestrials already discussed above. Like Les Temps modernes, it conveys the dehumanisation of the camps (one of the leads, moreover, is a woman, Maria, a member of the 'worker caste'). The 'happy ending' of the film, however, sits rather uneasily, as indeed does Chaplin's exit into the sunset having 'got the girl'.

The radically 'other' nature of parameters in the universe of the camps was such that the figurative could become literal. As LaCapra puts it, extreme traumatic events can involve the literalization of metaphor as one's wildest dreams or most hellish nightmares seem to be realized or even exceeded by brute facts' (1994: 180-1). ${ }^{35}$ In similar vein, Hochhuth describes the concentration camp universe in terms of the reification of metaphor, while Reiter notes that what was written as literal may be read as metaphor (Ezrahi 1980: 54; Reiter 1995: 77). When Tichauer refers to her parents as 'gone up in smoke [partis en 


\section{Textual identities II: textual constructs}

fumée]' (1988: 17), the expression would, in any other context, be read in its figurative sense: 'partir en fumée' can be defined as 'to vanish without trace'. In Auschwitz, however, the metaphorical becomes literal, though the extended definition of the phrase - 'to be wholly consumed without profit or trace' - is somewhat ironic: in fact, body fat was used to replace coke, while hair and gold teeth and fillings were sold at a profit. Alcan's sardonic word-play underlines a similar concretisation of metaphor: 'One day when she [her friend Fernande] was especially tired, she said to me: "They're going to kill us by degrees [à petit feu]", I replied: "Degrees centigrade [A grand feu]" (1947: 43). In some cases the reader may hesitate between a literal and figurative reading. When Wilborts, describing her friend Marijo who worked as a nurse in Ravensbrück states: 'She's carrying a sack, and in the sack are the bodies of her dead children' (1946: 120), we may well assume that this is some sort of figurative expression. Reading this statement alongside Marijo's own account of her taking the bodies of the babies she had looked after to the morgue, however, reveals that this is no metaphor:

The first time I had to take the tiny bodies to the morgue I felt as though I was descending into hell. The morgue was situated at the foot of a mound of sand, not far from the crematoria. You had to go down some stairs. The light switch was at the foot of the stairs. The first time I went down those stairs with three babies in my arms, I was in tears. I didn't know where to put them. In the end, I laid them in the arms of a dead woman, as if she were their mother. ${ }^{36}$

Boundaries between the metaphorical and the literal break down in the camps. When Tichauer states that 'Auschwitz is still tattooed in our bodies' (1988: 60), she is only a preposition away from the literal truth. Readers may be forced to reappraise tired clichés. Lévy-Osbert reminds us that a familiar dictum was sadly inappropriate in the context of Auschwitz: 'We fantasize about tomorrow's world, then about life after we've won the war. We comfort ourselves with the thought that although we'll inevitably have to work, no one ever died of hard work. Obviously' (1992: 95). Simple phrases such as 'a deathly silence' (1995: 65), used by Abadi to describe the tension preceding a 'selection' are read in a new, sinister light.

This chapter has revealed something of the difficulties and paradoxes which I would suggest are inherent to the testimonial enterprise at stake. Paradox as manifested in the deportee-writers' decision to 
adhere (however loosely) to non-fictional generic forms such as the memoir and journal, to avoid chronological complexity, and to stress the facticity and authenticity of their texts via paratextual material (footnotes, prefaces, embedded documents) while simultaneously mobilising a whole gamut of rhetorical and 'literary' devices most commonly associated with the realist novel. Paradox because in order to persuade the reader of the(ir) truth, a truth premised on their work as 'not-literature', these writers seek to sustain verisimilitude precisely by using literary devices. Paradox, finally, because in order to avoid a mystification of the events which occurred, the writers must facilitate the reader's capacity to imagine the unimaginable.

Where the first chapter focused primarily on authorial intention, this chapter has returned us to the key issue of reception already adumbrated in that first chapter, where we saw both that the eye-witness requires an audience in order that she be constituted as witness, and the deportees' insistence on the importance of communicating ('transmettre'), an area in which later deportee authors especially believed that the writers of history have failed. Now we see that in their attempt to engage the reader, the testimonial writers tread a dangerous tightrope: anything perceived by the reader to be excessive (for example, with respect to tone), over-intrusive (dialogue, shifts of tense), or inappropriate (humour, metaphor) can break the fragile reader-author contract, tipping the 'plausible' ('le vraisemblable') into the 'implausible' ('l'invraisemblable'). It seems clear that a degree of circumspection is required when we come to assess these writers in their testimonial endeavour. Unlike Jorge Semprun, these are not, for the most part, professional writers, and their ability to produce what Semprun refers to in an elegant oxymoron as the 'transparent density' which constitutes the successful testimonial account should not be judged too harshly. Semprun, one need hardly point out, is a male author, and while this monograph does not seek to engage in comparisons between male- and female-authored accounts, the following chapter does aim to reveal both the manner in which gender and sexuality are constructed within the context of the camps and some of the specificities of female-authored accounts. 



\section{Part II \\ Deportee identities}





\section{Deportee identities I Gender and sexuality}

In this the first of three chapters analysing deportee identities, the focus falls on representations of gender and sexuality. A gendered approach to the field of Holocaust studies has had its detractors, with objections coming in various forms. ${ }^{1}$ Some critics claim that differentiation by gender can give rise to undesirable comparisons between male and female deportees, which may lead to victim blame (women survived better than their male homologues because they showed greater solidarity, had more developed domestic skills, etc.). In a related polemical move, it is claimed that a focus on gender runs the risk of deflecting attention away from Nazi policy and its devastating consequences by accentuating the positive in an inappropriate manner. Langer thus typically claims that:

listening to the voices of women who survived these domains [the Nazi camps] reminds us of the severely diminished role that gendered behavior played during those cruel years. Even when we hear stories of mutual support among women in the camps, the full context of these narratives shows us how seldom these alliances made any difference in the long-range effects of the ordeal for those who outlived it. Because it can never be segregated from the murder of the many, the survival of the few cannot be used as a measure of why some women survived and others did not.

(1998: 351)

In a similar fashion, Joan Ringelheim, a pioneer of research into gender in the field of Holocaust studies, came to reassess her own work with the reminder that 'the Holocaust is a story of loss, not gain', going on to interrogate the viability of gendered approaches: 


\section{Deportee identities I: gender/sexuality}

What is resistance? Is anything an oppressed woman does an act of resistance? Is survival resistance? What if a person kills herself? Does suicide then become resistance? ... Is dying resistance? Is courage resistance? Is singing on the way to the gas chamber resistance? ... See how the terms become neutralized - worse, destroyed.

(Rittner and Roth 1993: 390) ${ }^{2}$

While both of these criticisms presuppose that a focus on gender equates to an emphasis on survival, perhaps the most commonly artic-

ulated objection to a gender-based approach asserts that the victims of Nazi policy were deported and killed as Jews (and by extension one might add as members of the Resistance, as Communists, etc.) and not as men and women, and that to focus on women exclusively is thus misguidedly to impose a so-called feminist agenda, and thereby to run the risk of trivialisation or banalisation.

In response to such viewpoints, it should be noted that this chapter does not seek to compare the experiences of men and women, though it facilitates such a comparison for those who might wish to make it, nor does it restrict its focus to women's coping strategies (an approach which in any event need not detract from the brutal reality of life in the camps). What it does do is reveal the extent to which claims that experiences in the camps were gender-neutral are quite simply illconsidered. Quite apart from the fact that gender played a key role in Nazi policy (women with children, for instance, were selected for death immediately upon arrival in the death camps; male and female deportees in the camps were segregated), it seems blindingly obvious that men and women had different experiences in the camps, and experienced similar events differently. This chapter thus includes analyses of various gender-specific issues, including: the female deportees' relationships (sexual and platonic) with men; same-sex relations; the female body; representations of motherhood; the adherence to, or departure from, traditionally conceived gender roles. The aim, in short, is to analyse how women perceived and represented themselves as gendered and sexual beings in the specific context of the camps, and how the latter generated localised constructions of gender and sexual identity.

Of course this approach runs the risk of inviting criticism of another form. As Horowitz points out, an emphasis on difference (menstruation, rape, motherhood) can produce as skewed a picture as a gender-neutral approach: where the latter 'produces a unified (unisex) version of the Holocaust that unintentionally ends up occluding expe- 
riences particular to women', the former 'inadvertently reproduces the marginalization of women, by presenting their experiences almost exclusively in terms of sexuality' (Horowitz 1994: 265). ${ }^{3}$ Horowitz warns against such a potentially essentialising approach by reminding us that 'women' do not comprise a unified group; that other factors or differences (in the plural) must be recognised. As will become clear as this chapter unfolds, constructions of gender and sexuality cannot indeed be divorced from other discourses - specifically, in this chapter, from those relating to class and nationality. Furthermore, subsequent chapters, focusing on political affiliation, class, nationality, and constructions of Jewish identity, are intended to afford a composite picture of the multiple discourses at play in the construction of deportee identities.

\section{Female/male relations}

\section{Sex and power}

Given the nature of the daily routine in the camps, the segregation of male and female prisoners, the strict surveillance and day-long work minimally fuelled by inadequate rations and sleep, it would be reasonable to assume that the deportees had little opportunity to flourish or indeed even function - as sexual beings. The segregation of deportees was, however, not absolute (work-details, especially those outside the camp-boundaries, brought men and women together), same-sex relations did take place, and the regulations governing contact between SS guards and deportees were flouted.

In the majority of cases, sexual relations in the camps are represented in highly negative terms: they are corrupt, depraved, redolent of criminality or bestiality. Why? Because sex is for the most part something done by the 'other', whether that 'other' be the SS, the often-loathed prisoner-functionaries, ${ }^{4}$ deportees - specifically those who are not French - who bartered sex for material goods, or, as a later section of this chapter will reveal, lesbians (or those designated as such). Sexual activity among the SS personnel or the latter and prisoner-functionaries is fairly widely represented, and in all cases is seized upon by the deportee writers as an opportunity to denigrate those involved. Brun, for instance, describes the interaction of female SS guards at Ravensbrück in terms of a regressive bestiality: 'You should see them carrying on like cats on heat, screeching with laughter, trying to get the attention of the male guards who bleat like complete cretins' (1979: 171). Such sexual activity could 
nonetheless have its advantages: as Brun points out, while the SS cavorted, surveillance was much reduced.

Sexual relations between the SS and deportees were strictly forbidden, but rules were nonetheless broken (Sofsky 1997: 105, 112). A distinction must be drawn, however, between those deportees elevated to the rank of prisoner-functionaries, especially the workdetail leaders or kapos, and the vast body of deportees. No sexual acts involving the SS of either sex and ordinary female deportees are recorded in the corpus of accounts. Much more common was rulebreaking involving SS personnel and prisoner-functionaries. Birnbaum singles out the German kapos - all, she states, former prostitutes who spent their time attempting to seduce male SS guards while the deportees were set to work draining the marshes surrounding Auschwitz. ${ }^{5}$ When the female deportees are joined by a group of male deportees, 'nearly all Russians or Aryan Poles', Lysel, the principal kapo, is apparently in her element: 'So many men! Men everywhere for Lysel and the guards! They don't know what to do with themselves, or with them... Lysel spends all her time in the huts and emerges halfcrazed, drunk, completely wild' (1946: 78).

And if female prisoner-functionaries engaged in sexual acts with male SS personnel, then the opposite scenario is also represented. Friang describes the relations between female SS guards and male prisoner-functionaries (picking up on the trope of bestiality with her use of the terms 'male' [mâle] and 'female' [femelle]): 'On the Saturday night the female SS guard, who didn't think one man was enough to sate her ardour, summoned a male "kapo" to join them' (1997: 182). Together with a male SS guard, the two proceed to engage in interesting threesomes' in front of the bemused deportees. Friang adds that her sexual education had by this time already advanced considerably: 'We'd already received some instruction from the ladies of the SS and a group of French volunteer workers, on and under the work-benches.... Travel definitely broadens the mind' (ibid.: 182).

The male prisoner-functionaries could themselves on occasion pose a threat to the deportees, as Améry indicates in the context of Mauthausen: 'The prisoner-functionaries manage to get hold of alcohol and after drinking invade the women's blocks on a nightly basis. We're scared to go to the toilet' (1945: 160). The fact that such rule-breaking involved only the prisoner-functionaries makes sense within both the logic of the camps and that of the representational process. Not only were these functionaries in most cases loathed by the deportees (hence their acts more likely to be represented in the accounts); they were able to communicate with the SS (many were German criminals) and, 
significantly, stood a rank above the mass of deportees in the strict camp hierarchy, operating, as Sofsky points out, in an ambiguous zone: 'It is true that a deep boundary line divided personnel from inmates. But in between lay a gray zone of power delegation and collaboration, protection and corruption' (1997: 97). Distinguished from the anonymous mass of deportees by their relative power, the prisoner-functionaries also found a place in the sexual hierarchy of the camps.

Only very rarely are sexual relations devoid of self-interest or power imbalances reported, and these tend to involve deportees who, though not prisoner-functionaries, were in relatively 'privileged' situations. Tichauer, who worked in the comparative comfort of the Raisko camp annexed to Auschwitz, explains that the presence of work-details of male deportees from Auschwitz facilitated her meeting with Otto, a German political detainee. Theirs is, however, a liaison recounted in a somewhat stark and perfunctory manner. Having stated matter-offactly that Otto became her lover, and that both volunteered to undertake Sunday guard-duty in the greenhouses, making love under the plant tables, Tichauer fades Otto out from her account only one page later, and does not mention him again.

For the most part, sex is revealed to be inextricably linked to networks of power. Not only were those in positions of authority more likely (have the opportunity) to indulge in sexual relations; those who lacked power and influence might use sex to improve their material circumstances. In many cases sex - or sexualised interaction - is thus represented as a currency in a system of exchange. Louria, for instance, refers to a deportee exchanging kisses with a Polish deportee working in the same factory work-detail for soap and toothpaste (1979: 26-7). Birnbaum points out the potential complexities of sex- and powerrelations: male deportees working in the coveted 'Canada' detail (sorting out belongings taken from deportees arriving in the camp) in Auschwitz might offer gifts to female deportees, who would then pass on a proportion of the goods obtained to the prisoner-functionaries. The latter, for their part, would turn a blind eye to further contacts. Such a system, as Birnbaum points out, could be beneficial to all (1946: 91). This system of exchange is often represented in morally neutral terms, though almost exclusively when French deportees are involved. Tichauer's account of male Polish deportees who worked as dentists in Auschwitz insisting that the female deportees masturbate them in exchange for dental services is non-judgemental: 'Once everyone has done their duty we are given a packet of margarine ... which we share out' (1988: 118). In some cases, however - notably 
when other nationalities are involved - the tone adopted is rather more hostile. Fénelon, for instance, records the very particular manner in which Lotte, a German deportee accused of exchanging sexual favours for food, goes about wooing potentially useful suitors:

She calls these handkerchiefs her 'love messengers'. She stuffs one you know where, right inside, and keeps it warm for twenty-four hours before sending it to her latest paramour, a truly hideous Kraut kapo. Talk about a love potion!

$(1976: 203)^{6}$

Although the deportees may be quick to judge those who engaged in such acts, 'normal' parameters did not, of course, apply in the camps, and the boundaries between coercion and consent - survival at what cost? - seem fluid, to say the least. In some cases, the apparent prostitution of the deportees in exchange for material goods was more formalised: as many accounts record, female deportees were invited to participate in camp brothels, set up for the SS, the prisoner-functionaries, and in some cases the male deportees. The presence of these camp brothels remains poorly documented. Morrison notes that the first brothel for prisoners was opened at Mauthausen in 1942, with 'recruits' drawn from Ravensbrück. By 1943 similar brothels had been set up at Buchenwald, Sachsenhausen and Auschwitz (Morrison 2000: 202-4).

Deportee reactions to the brothels range from resigned neutrality to outright horror depending on specific circumstances. Wilborts's mildly acerbic version of the 'recruitment process' at Ravensbrück is fairly typical:

On the third day the camp commandant asked which women wanted to eat, be well-dressed and have a tolerable life. All they had to do was become the plaything of these fine gentleman in an area set aside in the camp.

$(1946: 96)^{7}$

Most deportees, once again, are keen to differentiate the French from those of other nationalities who might agree to undertake such work, and the neutrality of responses tends on the whole to correlate directly to the degree of French involvement. Saint-Clair points out that no French deportees stepped forward in Ravensbrück (and calls attention to the fact that Russians and Poles did, 1945: 117); Busson's account of the situation at Mauthausen is less absolute (volunteers included 
'very few French women', 1946: 147), while Marette records the outraged reaction of the French (boos and cat-calls) when one of their number volunteers (1954: 142). Not all deportees are quite so censorious. Fabius records her defence of Chantal, a French prostitute who volunteered but was rejected on health grounds, and was subsequently ostracised by a group of French deportees. Here, too, various factors come into play. The leader of those who took an apparently principled stand against Chantal was, we are told, from a noble French family ('That's why we nicknamed her "Madam Two Castles and Six Turrets", 1986: 174), and her antipathy to Chantal seems to have had as much to do with class prejudice as with moral values. Tichauer, like Fabius, regards those prostitutes who volunteered in a less judgmental (and more pragmatic) light. As far she was concerned, if 'professionals' took up the proffered places, other deportees were less vulnerable to enforced recruitment (1988: 96).

In none of the contexts seen thus far can we talk, strictly speaking, of coercion - at least not of the physical variety. This, however, was not to be the case during the potentially dangerous period when camps were liberated. Ironically, the deportees were to suffer sexual aggression not at the hands of the Nazis, but primarily at those of the Allies. Avoiding rape by claiming illness was apparently a common strategy, and one which had to be deployed most frequently in the face of aggression from Russian troops. Friang's friend Danielle prevented an attempted rape at the hands of a Russian soldier by miming the symptoms of TB (1997: 232). Lasnet de Lanty indicates that although the Russians appeared friendly, their manner could quickly change: 'We much eat much laugh! But no women! No good no women! Come laugh and drink with us...' (1965: 231). While Lasnet de Lanty, we are told, beat a hasty retreat, Maurel's colleagues were apparently less fortunate, though the author's version of events is inexplicably casual:

By the time the barn door opened onto daylight and Michelle and Mitzy called me over to come and eat, a Russian truck had been in the farm-yard for a long time, and Michelle had already been raped once by a cheerful strapping lad who had immediately taken off again across the fields.

Maurel points out she was not raped because she had enough Russian to insist that she had ulcers and was highly contagious, but adds that the Russians continued to rape other French deportees over a period of several days (ibid.: 164-6). For many deportees the conduct of the Red 
Army was something of an embarrassment, and accounts reveal varying degrees and colours of political investment. London, for instance, acknowledges the conduct of the Russian troops with considerable reluctance: 'We regarded the heroes of the Red Army as so many legendary angel Gabriels slaughtering the dragon, quite incapable of carrying out such reprehensible acts. But it's true, there were rapes' (1995: 382). Sexual threats were not the sole preserve of the Russian soldiery. Crémieux, among others, notes that French STOs made persistent sexual advances in spite of the desperate physical condition of the newly-liberated deportees (1999: 105). By contrast, the Americans troops are consistently represented in a favourable light. Friang praises the helpful and respectful attitude of US officers, and states that the troops merely flirted (1997: 236), a point of view backed up by Maurel (1957: 176) and Bouteille-Garagnon (1948: 53-4).

\section{Supportive relationships, 'de-feminisation' and 're-feminisation'}

The previous section reveals that sexual relations involving female deportees were for the most part characterised by imbalances of power: some women used sex to enhance their material circumstances, either via informal networks of exchange or by opting to work in the camp brothels; once the surveillance and hierarchy of the camps were left behind, female deportees might be subject to the sexual aggression of their liberators. But relations between men and women, especially those of a non-sexual nature, were in some circumstances highly supportive.

By far the most the most favourably represented male/female relationship involves French POWs, barracked close to various minor camps such as Malchow, Apteroda, Holleischen and Torgau. French POWs in Stalag IV.C. exchanged information with the deportees in Torgau both by letter and direct contact (via work-details outside the camp), as well as supplying desperately needed food. Rather than viewing the women as potential sexual partners, the POWs took on a protective role and sought to provide emotional support: 'They've decided to adopt us as god-daughters' (Blanc 1984: 157). The men are represented in terms of both (traditionally) 'feminine' and 'masculine' traits. Pagniez relates how they cried when they saw the women for the first time (1947: 137-9), and refers to them as 'guardian angels' displaying 'brotherly affection' (ibid.: 149). Toulouse-Lautrec describes a final letter written by the POWs shortly before the deportees were moved on from Torgau as "both tender and virile, maternal and full of 
strength' (1967: 228). Even when direct contact was impossible, the POWs provided crucial support and desexualised friendship. Alcan praises the French POWs barracked near to the camp of Malchow for their continual support and letters of hope and good will: 'We feel protected by these sixty men whom we have never seen and who are such good friends to us' (1947: 93).

Although these relations are not sexual in nature, the presence of men - more particularly men assuming a protective role - is represented in some cases in terms of a re-feminisation of the female deportees. Corblet de Fallerans thanks a group of French STOs first because they sang French songs to raise the spirits of the deportees, but also because 'they still saw us as women' (1992: 136). A similar sentiment is expressed more forcefully in Pagniez's account of the moment the deportees learned that the French POWs were to deliver food to them:

Suddenly, as if something hard began to melt inside us ... we became women again, trusting, clinging on to a shred of hope; a poor group of women looking for a shoulder to lean on and who, in the midst of their infinite misery, experience the soothing sweetness of succour, like balm on a wound.

(1947: 149)

Once more a certain blurring of gender traits is represented: the men are described in terms of both maternal nurturing and virile protectiveness. Although this relationship is not characterised as sexual in nature, the presence of men served in some cases to alter the women's identity as gendered, sexual subjects - an identity which had to all intents and purposes been erased by their captors and guards. SaintClair records her momentary disgust when an SS officer failed to stand when she entered a room, and her subsequent realisation that she was not, in fact, a woman, but a prisoner (1945: 134). Birnbaum points out that there was little room for feminine modesty in the cattle-truck transporting deportees from Auschwitz to Bergen-Belsen:

There's no need to feel awkward when you need to use the bucket, the German is used to it. We lift up our dresses and our slips, and we sit down. He watches if he feels like it. Does he even think of us as women? 


\section{Deportee identities I: gender/sexuality}

In the eyes of the French POWs, however, the deportees were above all (French) women. Blanc notes the self-conscious response triggered by the very proximity of the French POWs stationed by Torgau: 'For the first time since our arrest we take a interest in our appearance (as is only natural), and are ashamed of the rags we're wearing' (1984: 149). De Loulay describes the impact upon the female deportees of the arrival of male deportees (primarily Russian, Czech and Italian) at Abteroda camp in a similar fashion - 'Everyone starts simpering and preening to get their attention' (1945: 148-9) - and articulates the female deportees' sense of a loss of gendered or sexual identity: 'They hadn't seen women for a long time. Are we women?' (ibid.: 149).

An awareness of de-feminisation and of the dislocation of traditionally conceived gender traits and roles also reveals itself in the accounts via two semantic phenomena: a certain hesitation or self-consciousness relating to the use of nouns in their masculine or feminine form, and the deployment of the feminised form of masculine nouns. Birnbaum, for instance, referring to an incident in which a male prisoner carrying out work in Auschwitz gave the women food, struggles to find an appropriate word to express female solidarity: 'We all wanted some of that chewed piece of bread and we shared it like brothers' (1946: 55, my emphasis). When seeking to characterise one of her coworkers, Alcan seems equally unable to find an appropriate noun in the feminine form: 'Then there's Erica who's the good bloke (if you'll excuse the expression) of the group' (1947: 72). In her description of the morning roll-call for work-details and the prisoner-guards' leading of their workforce out of Ravensbrück Améry comments wryly on the kapos' own use of a masculine term, in this instance explicitly linking the term to de-feminisation: 'The red armbands march their mann [sic] off to the workshops - they say their men, and not without good reason: we've nothing much of the "frau" left about us' (1945: 42, author's emphasis).

Pagniez too makes the connection between perceptions of gender and language when she describes a group of women watching from the barracks' windows, and explicitly hesitates between the masculine ('spectateurs') and feminine form ('spectatrices') of the noun, adding 'How can you tell with all these shaved heads?' (1947: 82). In other cases the deportee authors employ the feminised form of nouns which more commonly appear in the masculine (my emphases throughout): 'The German soldates [soldiers]' (Birnbaum 1946: 118); 'the camp cheffesse [leader]' (de Loulay 1945: 48) and 'the sous-cheffesse [second in charge]' (ibid.: 124); 'amatrices [amateurs of]' (Maurice, N.N. 1946: 40. 
Significantly, the feminised form reverts back to 'amateurs' in later editions of the text); 'doctoresse [doctor]' (Alcan 1947: 28); 'this typesse [bloke]' (Pagniez 1949: 100); 'the Bochesses [Krauts]' (BouteilleGaragnon 1948: 9); 'gestapistes or gestapettes [members of the Gestapo], take your pick' (Améry 1945: 10); 'Ministresse [minister]' (Blanc 1984: 380). In all cases it would seem that lived experience in the camps, which saw an undermining of traditionally conceived masculine and feminine roles, was a step ahead of linguistic conventions.

\section{Same-sex relations}

Deportee accounts without exception single out close female friendships, mutual help and solidarity as key factors underpinning survival in the camps, and indeed this is a theme which has been taken up by many critics. However, while information relating to the deportation of gay men is increasingly emerging, there is still little critical work on female same-sex desire (indeed data relating to lesbianism in France from the 1930s to the 1970s is scarce) (cf Lesselier 1993: 106). What material there is tends to be largely confined to short sections in texts which focus primarily on male homosexuality. ${ }^{8}$ As Vera Laska, whose curious use of the upper-case is perhaps in itself indicative of uncharted territory, puts it:

If there is hardly any documentation on male homosexuals in the camps, there is even less available on Lesbians. This will not change until a former inmate who was a Lesbian comes out of the closet and writes her memoirs.

Neither the 'Lesbian' nor the memoirs have yet 'come out' (and it seems rather late in the day for such a work to emerge). However, although none of the French female deportee writers in the corpus professes to being gay, nor (explicitly) to having same-sex experiences in camps, references to same-sex desire can be found in a high proportion of the accounts. Reasons for such a significant presence may be multiple: same-sex relationships may quite simply have been widespread in the camps (many accounts suggest that this is the case); such relations may, on the other hand, may have been sufficiently distanced from the deportees' everyday experience outwith the camps as to appear noteworthy; finally, references to those engaging in same-sex relations may, as shall emerge below, have served to reinforce a powerful nationalist discourse articulated by the French deportee authors. 


\section{Deportee identities I: gender/sexuality}

Strikingly, references to same-sex relationships are more common in early accounts and indeed are largely occluded in later works (published in the 1980s and 1990s). While the first wave of accounts, produced in the 1940s, aimed above all, as we have seen, to inform an ignorant public, to reveal all the facts, however 'shocking', in documentary detail, it may be that those writing some five decades later (older, of course, and distanced from the extraordinary circumstances of the war) might both experience a reluctance to revisit such events for personal reasons, and, perhaps more pertinently, be aware of the risks of inadvertently titillating their readers. Certainly prefaces in texts written relatively soon after the first wave of accounts already indicate an awareness of the potential danger, as Maurel's Un Camp très ordinaire (1957) reveals:

I was always asked the same questions:

'So were you raped?' ...

'Did you suffer a lot? Were you beaten? Were you tortured? What did they beat you with? Were you sterilised? What about the Russians, were they really terrible? Is that really all you had to wear? What did you do when you had your period? So tell me, all those women, were there homosexual relationships?'

(ibid.: 185)

In a revealing act of double-censorship, Mauriac's preface to Maurel's account comments on this list of questions, citing those relating to rape, beatings, torture, sterilisation, menstruation and clothing, but studiously avoiding any reference to homosexuality.

Representations of same-sex relationships in the accounts range from the openly homophobic to the display of a certain ambiguity, even ambivalence. Some, like Brun, who describes here (in unusually graphic manner) her experience in a toilet-block in the prison of $\mathrm{La}$ Roquette, remain resolutely hostile: 'I saw two women inside and one of them had her knickers down and was being caressed by the other one.' Her response - she is 'sickened and embarrassed' - is not shared by those in authority. Appraised of the situation with all the tact that Brun can muster, sister Geneviève merely accepts the inevitability of the situation: 'There have always been lesbians in prisons and there always will be, why do you expect anything different here?', 9 thereby provoking further outrage in Brun: 'We were completely flabbergasted. Was this some mad sort of world where anything is acceptable? Was I really so naïve? Would I have to put up with even more of these 
horrors?' (1979: 39). (Two of the three questions, at least, could be answered in the affirmative.)

Brun's unequivocal hostility is not entirely representative. Responses are on occasion less clear-cut. Consider Saint-Clair's description of another toilet-block scenario, this time in the context of Ravensbrück:

Framed in one of the windows a couple were entwined. Two Slav women, whose braided hair seemed auburn in the light, were kissing amorously. Who would have believed that even here such depravity would have free rein. I'd been warned. I could scarcely believe it.

(1945: 105-6)

The homophobic tones of the word 'depravity' ring out clearly enough, but seem curiously at odds with the lingering, aestheticised description of the women's hair, while the positive connotations of the words 'couple' and 'entwined' are such that the following sentence reads almost like a non sequitur. An element of fascination seems to be inscribed in the description; indeed the framing of the couple in the window hints at a pleasurable voyeurism more commonly linked to the male tradition (cf. Lesselier 1993: 114). Blanc's description of French deportees' nocturnal entertainment reveals a similar voyeurism: 'Lots of prisoners take advantage of the moonlight and entertain themselves in the block at night by watching what goes on in certain beds' (1984: 164).

Saint-Clair's reference to the 'braided hair' of the two women she observes is unusual. Most representations of lesbian desire invoke a strong male/female binary centred on the trope of inversion. ${ }^{10}$ Lesbians are usually referred to as 'Jules' or 'Julots' and labelled as 'mannish'. ${ }^{11}$ Le Guillerme's depiction is typical:

The cooks and other prisoners who hold privileged posts, Germans and Poles, are lined up on the Lager Platz [sic] to our right. Renée bursts out laughing:

'I don't believe it! Look at the third one in the front row - it's a man, unbelievable!'

'Amazing... At least that one isn't hiding the fact that she's one of them!'

'Look how's she's standing - legs apart, shoulders forward...'

'It's a "Jules", no doubt about it...' 
Dufournier sums up the situation in a similarly stereotypic manner:

The 'Jules' were a essential institution in the camp. The 'Jules' were the men of the camp. Usually Germans, black or green triangles or Bettpolitik, their physical appearance was somewhat disconcerting. With their masculine bulk, emphasised by a particular way they had of dressing (a 'Jules' would almost always manage to get hold of a pair of men's trousers and an equally appropriate jacket), their loutish faces with low foreheads, their hair cut deliberately short, and their murderers' hands, they could be spotted from afar.

The generalising reference to criminality ('murderers' hands') may derive less from homophobia per se, as from the association of lesbianism with a certain classification of deportee: German criminals (green triangles) and 'asocials' (black triangles). ${ }^{12}$ Elman notes that the latter group 'was so heterogeneous that lesbians were not as readily identifiable as were others, like gay men, whose colored patch exclusively signified their "crime"' (1999: 11). The association of lesbianism with German deportees bearing a green or black triangle seems to have been responsible for a certain confusion of identities in the representation of lesbians: the implication that they enjoyed a privileged status because of their sexuality. Le Guillerme (above) focuses on those deportees who 'held privileged posts', adding shortly thereafter that 'the "Jules" usually work when they feel like it' (1946: 196). Chombart de Lauwe describes a young German girl, Christel, as a 'Julot', going on to state that 'her dress is clean, she has shoes, stockings, an apron, she receives gifts, she is spoilt, she has a little retinue of servants. Many of her sort manage to secure influential posts' (1998: 100-1). Not only is de Lauwe's description of the young girl somewhat at odds with 'mannish' stereotype of the 'Julot'; her association of sexuality with privilege constitutes something of a misperception: privilege, where it existed, was nearly always dependent upon nationality and deportee categorisation. The fact that Christel enjoyed a position of relative power undoubtedly had more to do with her status as a German nonpolitical deportee than her apparent sexual orientation.

Representations of lesbianism which focus on both nationality and privilege often centre upon a particular area of Ravensbrück camp which seems to have assumed an almost mythical status: the feared 'Strafblock' (punishment block). Dufournier, who at one stage formed 
part of the painting work-detail, begins by informing her readers that this work-detail was filled with lesbian German green and black triangles. In spite of the other members' general antipathy to the French, Dufournier is apparently welcomed into the work-detail by its leader Hélène (described as 'seductive in some respects, particularly because of her undoubted physical allure', 1945: 137): 'she took to the new recruit immediately, the first normal prisoner she'd ever been in charge of' (ibid.: 138, my emphasis). Dufournier points out that many in this work-detail engaged in same-sex relations (indeed 'their homosexual tendencies were a little too conspicuous', ibid.: 139). Although camp rules officially prohibited such relationships - 'According to the rules such behaviour was not approved of and the crime of "LL" (Lesbienische Liebe) was subject to severe punishment' - those in the painting workdetail were rarely punished (for this or other 'misdemeanours') because they shared 'certain tastes' with those in the punishment block. The latter, indeed, is described by several deportees as a veritable hotbed of lesbianism. Like Dufournier, Améry points out that sexual relations between women in Ravensbrück were in fact rarely punished: 'It is forbidden to make love. Punishment: one year in the Strafblock. But nothing is forbidden in the Strafblock' (1945: 106).

So far lesbian acts seem to be the exclusive domain of German (or on occasion Slavic) deportees. But what of the French themselves? ${ }^{13}$ References to same-sex relations involving French deportees are rare. Busson identifies Francisca, a French prostitute (doubtless already beyond the pale because of her profession) as a "Julot" who was much in demand' (1946: 126). Blanc mentions 'doctor Claude (Anne Sp...)', informing her readers with some distaste that the latter formed a couple with one Carmen Mory, a block leader of 'monstrous' reputation. Blanc notes with a measure of satisfaction that Mory's treatment of the sick in the camp hospital was such that she was removed from her post, and Claude duly fell back into line (1984: 267-8). ${ }^{14}$ In Blanc's eyes, those engaging in lesbian activities inevitably get their come-uppance: we are told that another couple Annie (French) and Chouria end up in the camp Bunker (ibid.: 305-8).

Perhaps the most interesting - and revealing - representation of same sex desire involving French deportees can be found in Fénelon's Sursis pour l'orchestre (and those of a cynical nature might suspect that the success of this account is not wholly unrelated to the representation of same-sex relations). Fénelon operates a very obvious double-standard in her representation. The hostility with which she describes the activities of German deportee Lotte has already been discussed above. For Fénelon, exchanging sex for material goods and 


\section{Deportee identities I: gender/sexuality}

engaging in same-sex relations can be classed together under the general label of depravity, as the following withering remarks suggest:

We are all sickened by Lotte, flaunting her sex, her thighs spread open, offering herself to all and sundry. The constant casual sex engaged in by Wisha, Zocha and Marila - a real travesty of love is simply disgusting.

(1976: 175)

When members of the Auschwitz orchestra of which Fénelon is a part perform for the German black triangles in exchange for food (the irony of Fénelon's involvement in this barter is not noted), the author's description of the ensuing scene combines the stereotype of the pisaller - lesbian desire as a poor substitute for heterosexual sex - with images of contamination and coercion: ${ }^{15}$

This drunken revelry, this travesty of other orgies, was essential to these women who are used to having men every day in their line of work ... Ninety percent of them had become homosexuals, doubtless for want of any alternative, and also because it took a certain number of them to lay down the law.

(ibid.: 337)

However, another same-sex relationship is described in Fénelon's account; one which involves a young French girl, Irène, and the German Marta. ${ }^{16}$ Having objected to the highly visible sexual relations of non-French deportees, Fénelon proceeds to narrate the various stages of what is presented as a budding romance in some detail, to condone the growing relationship, and indeed to cite the protagonists' revelations about the pleasure they discover:

Fania, I was completely ignorant, and so was Marta, and we seemed to know what to do, one thing led so naturally to another. Everything between us went so smoothly, it was so simple. We made love and we experienced pleasure. It was so wonderful to come in her arms, because of her, with her.

(ibid.: 294)

Ironically, in spite of the protagonists' reiterated references to sexual pleasure, Fénelon concludes that the relationship was primarily a source of human warmth and tenderness and that pleasure was merely 'a bonus' (ibid.: 295). Irène's relationship is written off as a passing 
phase, and Fénelon cannot resist referring in the Epilogue to the young woman's subsequent marriage. It would seem that while Germans and those of other nationalities had sex, French deportees were involved in loving relationships. ${ }^{17}$

For Fénelon and others, those seeking human tenderness in samesex relationships must be differentiated from 'true' lesbians, who might attempt to 'contaminate' or otherwise coerce others. Fabius's remarks reveal a similar point of view: 'A lack of affection, human warmth and attention made some women more vulnerable than others to such "feminine tributes"' (1986: 181-2). Abadi is also eager to draw clear lines of demarcation: "If some of us try to soothe our shattered nerves, or can't bear not having an object for our affection, others are so "typical" that you couldn't make them up' (1995: 62). Where lesbian relationships are represented in a (grudgingly) positive light, it is due to the tenderness and nurture displayed by the couple. Sex is, in such cases, elided from the picture. Blanc refers to a 'Jules' who visited her dying partner several times a day in the Ravensbrück hospital: 'it's amazing how these Lesbians love each other! No man, however smitten, is so attentive, so devoted, so affectionate towards the woman he loves' (1984: 346). It is unfortunate that it is illness, nurturing, and ultimately a deathbed scene which touch the author: 'It is the only time in my life that I have been truly moved by the sight of two Lesbians' (ibid.: 347).

However positive representations may be, most of the accounts display one key feature: the expression of fears that boundaries between straight and gay may be misidentified. Same-sex relations may, at a push, be tolerated - as long as sex is not mentioned - but only if they are something engaged in by others. References to gay relationships may thus be brought together with comments affirming the author's heterosexual credentials. De Loulay, for instance, passes from a description of two women having sex in the bunk above hers to a reference to her (male) partner:

There are two foreigners there who ... are trying to reach seventh heaven (O Pierre Louys! O Lesbos in bloom!). I try to make myself inconspicuous. For hours, heart in mouth, I'm on the point of falling off my bunk. The snores, the muttering and murmuring, bodies tossing and turning. 'Jacques, are you in the same state as I am? Maybe worse.' 
Strong platonic friendships are studiously differentiated from lesbian desire. Dufournier draws a distinction between the 'pure' bonds which existed among the French deportees and the German 'asocials' who pursued them (to no avail):

A friendship born in the solitude of the cells in Fresnes, source of an ideal and abstract Fraternity which extended from cell to cell, to every prisoner. ... What do the German 'black triangles' whose paths we cross every evening at the far end of the blocks make of it? Do you want to be our 'friends', they ask us, accompanying their propositions with lewd gestures.

(1992: $163-4)$

Other accounts reveal fears that deportees engaged in close friendships might be mistaken for lesbians. When le Guillerme's friend Yvonne is upset, the couple embrace, lie down together under a table and chat (about Yvonne's husband, among other things). Rumours soon spread, and le Guillerme decides that such activity must stop: 'we have too many private conversations, we kiss each other too much' (1946: 135). Although Yvonne points out that they have done nothing wrong, le Guillerme insists that they must, as French women, set an example: 'There may be women among us who want to do what we're accused of, and our attitude would just encourage them' (ibid.: 136). A similar situation arises when Brun, suffering from the cold, shares a blanket with Raymonde:

We had to wait until the last night patrol had passed because those women with their warped minds claimed that we were that way inclined. It really was outrageous, given the disgusting things that were going on left, right and centre which they ignored or refused to believe were happening.

A similar attitude is also revealed in a number of highly defensive 'jokes'. Disgusted by her discovery of lesbian activity at La Roquette, Brun and her friends (mentioned at the beginning of this section), feel the need to act out (literally) the gay scenario: 'This little episode subsequently became a source of great humour, even a little ballet' (ibid.: 39) (the mind boggles). Defensive humour - surely indicative of a certain ambivalence - is reported in several accounts. Saint-Clair cites the exchange between two French women: "Don't stroke my head", said Mireille, the Marseillaise, to her neighbour, "you're giving 
me evil thoughts"' (1945: 72). Pagniez reports the reaction of one French deportee whose bed-mate constantly encroaches on her space by thrusting her feet in her face: “'My dear, hissed one of them furiously, when we get back to Paris I'll tell all the men that you're quite unbearable in bed!"' (1947: 94). ${ }^{18}$

Although the accounts reveal a range of attitudes to same-sex relations, ultimately male/female and heterosexual/homosexual binaries remain strong. Sexual discourse is, moreover, closely tied in with nationalist discourse: same-sex relations - especially those involving sex - are the preserve of Others, most notably Germans.

\section{The female body}

If, as we have seen, the deportees report feeling that in the absence of men they are 'no longer women', this sense of de-feminisation was undoubtedly due in equal measure to the physical condition to which they were soon reduced. Many of the accounts provide extensive descriptions of the female body, often presented in terms of the grotesque, and, it would seem, suggestive of a degree of (self-)disgust which one would not expect to encounter in male-authored accounts. In nearly all cases descriptions of the body stress the loss of secondary (sexual) characteristics. Brun, among many others, focuses on the breasts of the deportees: 'Oh! Those poor emaciated bodies, skin loose and sallow, breasts like two empty gourds, those same breasts once swollen with milk in the miracle of motherhood, the source of life' (1979: 154).

Brun points out that her own body was rapidly reduced to that of a pre-pubescent girl (ibid.: 154), a view echoed by Fénelon's description of the deportees as 'flat as pancakes' (1976: 233). In her account of the early days of her incarceration Friang compares the smooth bodies, flat stomachs and 'pert breasts' of the young to the bodies of

old peasant women with misshapen limbs, their breasts flapping and wrinkled, or, like half-empty gourds, hanging from folds of skin over their pot-bellies. Twisting varicose veins, deformed feet, ulcerated, blistered and puckered buttocks sagging over their spindly legs.

(1997: 138)

Commenting later in her account on the extreme emaciation of the deportees and the disappearance of hips and breasts, Friang acknowledges that even the young were to suffer the vicissitudes wrought upon 


\section{Deportee identities I: gender/sexuality}

the female body: all the deportees soon take on an androgynous appearance (ibid.: 181-2); Friang herself has the body of a puny twelve-year-old girl' (ibid.: 209). The contrast between the physical condition of new arrivals with that of those who have been in the camps for months, or years, is also brought out by Pagniez in two sharply contrasting descriptions, the first of which (referring to new arrivals) once again focuses on the secondary characteristics of the female body: 'Plump arms twisting up magnificent flowing hair; chests thrust forwards with smooth firm breasts; broad hips accentuating slim waists and supple backs' (1947: 75). A strong sense of pathos is generated if we compare this representation of the female body with that of a group of Hungarian Jews who arrive from Auschwitz: 'skeletal limbs covered in reddish swellings and welts, hollow bellies, bluish goitres, swollen legs ... and purple oedemas. Witches' breasts flapping and drooping like empty gourds, humpbacks, atrophied muscles sagging over hips, as slack as old elastic' (1947: 81-2).

The sense of 'no longer being women' occasioned by the loss of physical sexual characteristics was compounded in many cases by amenorrhoea, caused primarily by acute weight loss, though commonly attributed by the deportees to deliberate intervention by the SS (usually accused of adding saltpetre or caustic soda to the deportees' food). In the early stages of deportation, menstruation was an inconvenience, even a risk, as Aylmer-Roubenne indicates: 'There are no sanitary towels. Anyone with bloodstains is severely punished. You can be selected for lesser crimes. Fortunately women soon stop having their periods' (1996: 44). Mallet, addressing 'female readers who will know what I mean', observes that while women were still menstruating they were obliged to use pieces of cardboard as sanitary protection (1949: 88). Though amenorrhoea was, in practical terms, a blessing, it was equally a source of deep anxiety for many. Fénelon notes that the discovery that some women were still menstruating caused a degree of jealousy. As Hilde, another member of the orchestra puts it: 'It's awful not to go through this time of impurity any more, we no longer feel feminine, we're like old women!' (1976: 140-2).

\section{Nudity}

The very fact that the deportees were in a position to comment on the physical state of fellow-prisoners' bodies is, of course, significant in itself: it is important to realise how far public nudity transgressed the norms of modesty of the era. Benoist-Lucy, for example, prefaces her 
account with a reminder of the fact that as a young girl she was brought up according to rules of decorum and propriety which harked back to the previous century (1994: 10). Aylmer-Roubenne informs us that she refused to undress in front of her husband on her wedding night, demanding that the hotel provide a screen (1996: 26), and Corblet de Fallerans notes that many older women had never appeared naked in front of their husbands (1992: 125). That many of the deportees should single out their experience of nudity for widespread comment is thus unsurprising. Of greater interest are the coping strategies deployed for dealing with this unfamiliar situation, and the differing attitudes displayed depending on those who observed the women.

Although female observers in the form of other deportees undoubtedly provoked acute embarrassment - especially among the elderly for the most part the situation could be treated with a certain amount of light-heartedness and solidarity, as Toulouse-Lautrec's account of good-natured banter and defensive humour in the showers at Montluc reveals:

Shrieks of laughter from the next cubicle:

'Ah! Mado, you're a really weird shape you are, you've got no chest!'

'Well my dear, the Good Lord knows what He's doing, yours is big enough for two!'

'Hey, show us your beauty spot...' ...

Sighs from the left-hand cubicle:

'That it should come to this, at my age, I've never seen anything like it.'

'Come on, you're not a mummy; a bit of water won't do you any harm, don't worry, it'll keep you young.'

In cases where the observer was a man, however, the most commonly represented response on the part of the female deportees was their attempt to seek to deny the humanity of the observer, thereby reversing the more usual objectification of the woman by a male gaze. Marcelle Christophe's letter to her mother, sent from Drancy, typifies this stance:

Communal life is driving us mad. It is always crowded, even in the toilets. People strip off quite oblivious to those around them. 


\section{Deportee identities I: gender/sexuality}

If a man is there, well too bad. People try to cover up a bit, but without making a fuss. He may as well be a footstool!!!

This process of objectification is particularly employed in response to the gaze of the German guards. Renault records an exchange between the elderly Irène Tillion and a fellow-deportee: "But Mrs Tillion, you're in your under-garments and the corporal is about to pass by!" With her usual subtle smile Irène replied: "Well, my dear, for me a German is just an inanimate object!"' (1948: 38). Crisimily's response to being forced to stand naked in line for inspection by SS guards is similar:

We maintained our dignity in the face of the stream of insults generously directed our way. We laughed about it, saying: 'The fact that they look at us leaves us completely indifferent, because in our eyes they're less than animals. It is not men who are staring at us, as far as we're concerned they don't even exist. There is no reason to feel ashamed.'

(1981: 130-1, my emphasis)

When Lévy-Osbert is granted the unusual privilege of showering in the Union arms factory at Auschwitz, the disturbing presence of a male SS guard is soon neutralised:

I have to find a way to deal with this. And, as a wonderful feeling of well-being comes over me, I'm surprised to hear a voice in my head saying over and over: 'Filthy little man, filthy creature! filthy Nazi! You're not a man, you can stand there as long as you like. As far as I'm concerned, you're just a mannequin, just a shadow cast on the wall.'

(1992: 124, my emphasis)

By the time the deportees left the camps, norms of 'feminine' modesty had been cast aside. When Lagrange is given the welcomed opportunity to bathe in the bathroom of a house requisitioned by soldiers, she is surprised by the privacy granted her: 'Having accompanied us thus far, they discreetly closed the door behind us. We were astonished, we'd lost all sense of modesty' (1997: 125). Friang reports being equally sanguine about appearing nude: 'I no longer understand that a man might be taken aback by the sight of a naked young woman by a river. I look at him, astonished, then carry on washing' (1997: 240), as 
do Maurel, who is whisked swiftly out of the male shower block in a reception centre by a horrified female official (1957: 180), and Marette, who undresses in front of her male liberators with no qualms because, as she tellingly states, 'I've lost all sense of femininity' (1954: 226).

\section{Shaving of hair and the gynaecological examination}

Not only were the deportees forced on numerous occasions to undress in public; upon their arrival in the camps they were subjected to the humiliation of having their heads, and in some cases all body hair, shaved, ostensibly to prevent infestation by lice (Corblet de Fallerans suggests that shaving was actually entirely arbitrary, 1992: 123). ${ }^{19}$ Mallet's response to the experience may seem somewhat hyperbolic - 'I confess that the childish fear of losing my hair was one of the things which most tormented me during the time I spent in Germany' (1949: 41 ) - but it is not altogether atypical. Commented upon in nearly all accounts, the shaving of hair is most frequently represented in terms of an assault upon the deportees' femininity. Schapira asks: 'Is a woman's hair not said to be her greatest asset', adding 'It was like a violation, our femininity was being taken from us' (1994: 57). Picard, who seems to be aware of the apparent incongruity of her response, and who is consequently almost apologetic about her attitude, nevertheless comments on the loss of her hair in similar terms:

I will never forget that feeling. I wasn't vain about my appearance, far from it. My mother despaired of me. But before I was arrested I'd decided to grow my hair and it was already quite long. No more hair. Shaved head.

While representations of enforced nudity and the shaving of hair vary very little from the early accounts written in the 1940s to those produced in later decades, one aspect of the camps is - like same-sex desire - largely absent from later publications: the gynaecological examination which the deportees often had to submit to when they first arrived in the camps. Most of the deportees refer to this traumatic moment in terms of humiliation, a sense of invasion, and a horrific lack of hygiene. Brun reports with disgust that the same (unwashed) rubber glove served for all (1979: 138), as does de Loulay (1945: 79). Marette also states that one glove, which bore traces of blood from previous contacts, was used for an entire convoy of some six hundred women, with no disinfectant (1954: 160). 


\section{Deportee identities I: gender/sexuality}

Beyond the humiliation and risk of infection, several deportees point out that the examination could cause severe pain, and in many cases graphic descriptions of the procedure are linked to younger deportees' fears of what they perceive as the loss of their virginity. Brun's description is not atypical:

Suddenly I scream like an animal having its throat cut. With no consideration for the fact that I'm a virgin, he shoves the speculum violently inside me, shortly followed by his rubber-clad finger .... A bit calmer after talking to other young women in my convoy who underwent the same experience, I realise that my virginity must be a thing of the past.

Renault prefers to pass over in relative silence what was clearly a traumatic incident: 'The next day there was another medical visit which I still find it hard to think about' (1948: 38).

\section{Hard labour, violence, punishment and torture}

Enforced internal examination and the shaving of hair can both be regarded as forms of assault upon the female body, but of course there existed other, more horrific forms of physical aggression in the form of punishment, physical violence and torture. Before considering these ultimate manifestations of the brutality of treatment meted out to (some of) the female deportees, brief mention of the various workdetails in the camps should be made, for these too were in many cases physically debilitating.

All deportees, with the rare exception of those who managed to escape the morning round-up for work-details, or those who were confined to the camp hospital block (in cases of severe illness only), were put to work, usually for twelve hours at a time. Though an extensive discussion of types of labour will not be undertaken here, it should be noted that many work-details involved hard manual labour (felling trees, draining marshes, shifting large quantities of sand, earth, or rubble, breaking rocks) which inevitably led to extreme exhaustion, injury and illness. Ironically, as the Vichy regime, with its strict regimentation of gender roles, stressed the fragility of the 'weaker sex' (cf. Pollard 1998: 86), the female deportees were undertaking work usually carried out by men. Some articulate their reaction to this departure from traditionally gendered tasks. Fabius reports her objections that felling trees is inappropriate work for a woman: 'This is 
man's work, and we may be prisoners of the Great Reich but we're still women' (1986: 176). Lasnet de Lanty observes ironically that the varieties of manual labour in which she is engaged are 'all types of work ideally suited to women!' (1965: 180). Lorge has recourse to similar irony, underlining a more serious point when she refers to the exhausting nature of factory work which involved the manipulation of 'machines built to be used by men' (1992: 12). Maurice describes various unpleasant work-details, including the deployment of spade and wheelbarrow, in a chapter ironically entitled 'Occupations for young ladies, or how to put your skills to the best use' (1946: 39-41).

Although the debilitating consequences of such work should not be underestimated, some deportees do, nonetheless, represent the experience of carrying out such work in a more favourable manner. Alcan remarks upon her new-found skills with a mixture of irony and pride: 'I'm beginning to make real progress in the correct use of a pickaxe!!!' (1947: 30), and de Loulay, working in a forest detail, revels in her newly discovered physical strength (1945: 130). Roux also accentuates the positive:

A gang of women wielding axes, pickaxes, saws, spades...

A gang of women who grow stronger every day, more tanned, more swaggering...

Unflinching eyes... A stout heart... With something of both the saint and the buccaneer about them... That's the sort of women who will be loosed on the world come liberation.

(1946: 208)

Roux's positive take on hard labour is, however, not the norm. What might be termed the chronic violence represented by forced labour in the camps contributed to many deaths, and the deportees were to endure further, more acute forms of physical aggression. For many of the women interrogation prior to deportation was their first experience of extreme physical violence. Busson, among others, recounts both witnessing and being subjected to torture by the SS in Paris (1946: 42-3), and Paul (who escaped from Ravensbrück in August 1944) gives a detailed account of her torture at the Gestapo headquarters in Berlin (where she was recaptured in 1944) (1962: 108-14). ${ }^{20}$ Friang's description of her arrest and interrogation focuses specifically upon the hypocrisy of Nazi attitudes to gender:

A man came up to me. He pulled my dress back down to cover my legs. Torturing people to death in a cell in the rue de Saussaies is 


\section{Deportee identities I: gender/sexuality}

acceptable, but in public decency must be maintained. A young girl should not show her legs like that in the middle of the road. The Gestapo has its principles.

(1997: 73)

Friang subsequently endured severe beatings, which she once more describes in gendered terms:

The man takes it out on my chest. Beating a woman's chest with one's fists doubtless has its attractions. It's a way of working out all those little resentments. Especially when the woman in question can't defend herself, or escape. It must make him feel really manly.

(ibid.: 82)

Three deportees - Lesèvre, Bauer and Lagrange - give accounts of their torture at the hands of Klaus Barbie. While Bauer elects to omit any details (1993: 110-12), Lesèvre spares her readers little in her description of the nineteen days and nights of torture which she endured (1987: 43-59), and Lagrange, who was only thirteen years old, describes a series of savage beatings at the hands of Barbie (1997: 28-32).

Once in the camps, physical violence was part of the daily routine. ${ }^{21}$ So-called 'punishments' (often barely distinguishable from gratuitous acts of violence) ranged from deliberately protracted roll-calls during which the women were forced to stand, often in extreme temperatures, for hours at a time (cf. Morrison 2000: 225), to severe floggings (the 'norm' was twenty-five blows). Several deportees suffered the latter form of punishment: Fabius received fifty blows after being recaptured subsequent to her (temporary) escape from Ravensbrück (1986: 199-200); Paul (1962: 115-16), de Loulay (1945: 169-71), and Touboul (1982: 115) each endured a punishment of twenty-five blows. In the most extreme cases, punishment took the form of public execution. Two incidents are recorded by several deportees. The first took place at the sub-camp of Holleischen, where three French women, accused of sabotaging machinery, were publicly hanged. JeanninGarreau's text includes a sketch of three women hanging from gibbets with the caption: 
The machine they were using in the factory has blown up.

They have been found guilty of sabotage. They were called

Françoise

Hélène

Little Mimi.

$$
\text { (1994, unpaginated })^{22}
$$

A number of deportees record the public hanging in Auschwitz of four women accused of procuring explosives from the Union factory used to blow up the camp crematoria, providing readers with important eyewitness accounts - from a different perspective - of this well-known example of resistance (Langbein 1998: 500-2). Touboul, who gives the fullest account, describes how the deportees working the 'night-shift' were lined up to watch the hanging of two of the four women concerned; the other two were executed the following day in front of the remaining Union work-detail (1982: 137). ${ }^{23}$

Contrary to what gender stereotypes might dictate - and AylmerRoubenne points out that the American judges at the 1949 trial of Ravensbrück personnel at Rastadt held to just such preconceptions: 'The judges doggedly upheld a particular image of women' (1996: 155) - the perpetration of extreme violence upon women was not, of course, the sole preserve of men. Most punishment in the camps was meted out by female SS guards, while (female) prisoner-functionaries routinely engaged in acts of random physical violence. Beating prisoners to death was not uncommon, as many accounts record, and the majority of deportee authors single out examples of female aggression, many citing specific names (that of Dorothea Binz, senior overseer at Ravensbrück, comes up repeatedly, as does that of German prisonerfunctionary Käte Knoll). Curiously, the fact that women should so readily commit violence on other women is rarely commented upon, but there are occasional exceptions, one of which is noted by several deportees. Lahaye, who provides the most detailed account of events, describes how a French deportee, Cécile, was savagely beaten by female guards for the 'crime' of breaking ranks a little too quickly when her work-detail was permitted to break briefly to use the toilet facilities at Barth camp. Her friend Armelle rushed to her aid, shouting:

'Sie sind eine Frau'. 'Eine Frau' she screamed back. She threw Armelle to the ground and kicked her repeatedly in the groin and breasts, doubtless to demonstrate that being a woman, she knew how to target the most sensitive spots.

$(1954: 21)^{24}$ 


\section{'Feminine' preoccupations}

\section{Keeping up appearances}

Although in many respects conditions in the camps clearly did not facilitate an adherence to traditional gender roles - women participated in 'men's work', they were beaten, their bodies reduced to an androgynous state - in some respects the French deportees nonetheless resolutely continued to perceive and present themselves as 'women', and more specifically, as 'French women' with a national reputation of elegance to uphold. The vast majority of accounts lay great emphasis on clothing and what is represented as a particularly French ability to maintain a certain feminine 'chic'. Even before they arrived in the camps, and in the most extreme conditions, the deportees were apparently anxious to keep up appearances. Held in the fortress of Cologne, Benoist-Lucy is concerned above all by her bedraggled state: 'I was ashamed to appear dressed like that, me, a French woman' (1994: 39). Marette, held prisoner in Fresnes, reveals a similar anxiety:

I wash quickly, shake my dress out carefully, I want to look as presentable as possible. I do my hair as best I can without a mirror. I wipe my shoes with my blanket. I have to show that after three weeks of solitary confinement in a cell a French women can remain a woman.

(1954: 40, my emphasis)

Representations of the arrival of the French women in the camps frequently stress the manner in which they stand out from other deportees. Wilborts describes the arrival of her convoy in Ravensbrück: 'Through miraculous care for their appearance, the women are still well-dressed, their hair neat and tidy; the German women, huge and lumbering, cast envious glances at us: Parisians, French women!' (1946: 94).

Clothing remains a constant preoccupation, and Maurice approaches the topic with typical humour:

My dear, it's quite like being at the beach! A somewhat crowded beach, to be sure! Just look at the snobbish way those society women in their elegant striped dresses wield their spades and wheelbarrows... And we all have such slim figures! 
Lesèvre refers to a ready-made 'Camp Newspaper' in Ravensbrück with a special section entitled 'Women's Corner': 'There was - I'm not joking - a special section on fashion. This year's fashion was definitely stripes!' (1987: 103). Lasnet de Lanty describes the French deportees' participation in a New Year's Eve 'Haute Couture' fashion show: 'Draped in blankets they introduce the latest Paris fashions.' The final 'model' to appear wears 'the latest Berlin fashion': naked, entwined in grubby paper bandages, she symbolises the miserable state of the German populace (1965: 172).

Clearly gender and nationalist discourses intersect in such representations. Not only do the French seek to maintain their national reputation; they also differentiate themselves from other nationalities, especially (but not exclusively) the Germans. Lorge's description of French 'elegance' concludes on a typically patriotic note:

When we visit our friends in their sleeping quarters we find them looking wonderful; they'd found time the evening before to put curlers made of bits of left-over cloth in one another's hair. 'Ah! those Frenchies, nothing can put them down!'

Chombart de Lauwe stresses the French deportees' 'feminine' aptitude:

Those who are fortunate enough still to have hair, style it carefully. Dresses, shortened and pulled in at the waist, are soon trimmed with little white collars. We are still women and some even manage to look pretty in their pitiful dresses.

(1998: 97, my emphasis)

The French deportees' skills and fashion knowledge were such, indeed, that they were much sought out for advice. Schapira relates the manner in which the French women in Auschwitz managed to adjust and sew their striped tunics to great effect, eliciting admiration not just from the other prisoners but from the female SS guards, who gave them sewing to work on. As Schapira puts it: 'Even in a camp, and even in the most awful conditions, a woman is still a woman, and it's true that the French women have good taste and want to keep up appearances' (1994: 95). When one French deportee - tellingly described by Lesèvre as 'a real nationalist' - puts her hair in two plaits, the SS guard is quick to quiz her: 'The guard, who likes to think she has style, is eager to find out if that is the latest Paris fashion' (1987: 55). Fénelon, 


\section{Deportee identities I: gender/sexuality}

similarly, reports being questioned by other members of the Auschwitz orchestra about the latest trends in Paris (1976: 69).

Two symbols of femininity are repeatedly mentioned in the accounts: make-up and bras. Although the deportees were forbidden to wear the latter, the French apparently made great efforts to procure them and were not afraid to break the rules. Roux refers to the fashioning of bras from spare material cut from the bottom of dresses (1946: 103), Friang notes that many women hid them 'because bras are forbidden in concentration camps. They must be a symbol of Judeo-Gaullist-plutocracy' (1997: 130). According to Corblet de Fallerans, Hitler himself disapproved of bras as an unnatural constraint (1992: 123). When Marette manages to obtain a mirror, lipstick and powder she is immediately informed that such accoutrements are forbidden. In the eyes of the SS, Marette's behaviour is, moreover, typically French: 'Look at that one! She's wearing make-up. Needless to say, it's one of those bloody French tarts" (1954: 214). Roux comments on the French deportees' joy at obtaining cosmetics when the camps are liberated: 'By some inexplicable miracle we laid our hands on face powder, lipstick, combs and ribbon!' (1946: 212). Fénelon, lying seriously ill in Bergen-Belsen, reports singing the Marseillaise, and her feelings when a Belgian officer responds by handing her a lipstick: 'I can't think of a better present than that old lipstick, nearly used up, which had come from goodness knows where and goodness knows who - his wife, his fiancée, a prostitute...' (1976: 20).

Some deportees adopt a more critical attitude. Lasnet de Lanty comments on the thwarting of the French deportees' attempts to keep their cosmetics:

Walking down our ranks soldiers told us to wipe off our lipstick and powder or face a beating:

'Not allowed here!'

Those women who had 'done their faces' before arriving - what did they expect to find in Germany for God's sake! - quickly wiped their lips and faces with their handkerchiefs.

(1965: 77-8)

Améry associates the desire to remain neatly dressed and made up with a degree of naïvety: 'Forty-three French women arrive in Ravensbrück, armed with their lipstick and their illusions' (1945: 24). Finally, Blanc reports the arguments which broke out among the deportees in Torgau when some deportees - she suggests only criminals and prostitutes - 
ask POWs to procure lipstick before even considering the need for more practical goods such as food and soap (1984: 163).

\section{Recipes and other domestic preoccupations}

Those deportees who objected to, or distanced themselves from, such a 'feminine' preoccupation with clothing and make-up are very much a minority, as are those who took a stand against another common pastime shared by many of the French deportees: the exchanging of recipes. Given the extreme conditions of hard physical labour and minimal calorific intake, it is to be expected that many deportee accounts refer to interminable conversations about food. What is perhaps more surprising is the fact that a significant proportion mention women not just talking about food, but endlessly exchanging detailed recipes and menus, often striving to preserve these on paper. Maurel's account is typical:

Practically every woman in the camp kept a notebook for recipes. Some notebooks were renowned for the wealth of their material and were passed around. People booked their turn in advance.

'Madame Dupuis! When can I copy out your apple pastry?'

'Maybe Sunday. But I've already promised the notebook to someone else for the quiche lorraine'.

(1957: 134)

While some regard such seemingly obsessive behaviour as a pathology driven by extreme hunger, ${ }^{25}$ most commentators interpret the exchange of recipes as a positive act which contributed towards a sense of community, served to establish a continuum between past and future, and to reinforce women's identity as homemakers. For some, the phenomenon reflects a more generalised tendency towards emotional sharing which constituted a gendered form of resistance (Goldenberg 1998: 335; Fine 1990: 85). Such interpretations are doubtless valid, but not all deportees accepted the exchange of recipes without question. Friang, for instance, is rather more hostile in her comments:

We'd no sooner settled in than the French contingent's usual grousing started up and the inevitable swapping of recipes. I wonder if our enemy sisters discuss different ways of cooking 


\section{Deportee identities I: gender/sexuality}

borsch, or goulash or lamb chops. I fear that the recipe vice may be our national prerogative.

Friang's highlighting of the intersection of gender and nationality is apposite: any discussion of food, trivial a topic though it may seem, must be read in the context of officially dictated essentialising discourses. In the Germany of the 1940s, after all, female identity was officially linked not just to 'Kirche und Kinder' but also to 'Küche'. ${ }^{26}$ And not just in Germany. While practical considerations are partly responsible for French women's focus on their recipe-books - rationing in Vichy and Occupied France began in September 1940, and Célia Bertin informs us that 'in the autumn of 1940 women from all walks of life started talking about recipes' (1993: 40) - it is important to bear in mind that the National Revolution of Vichy, like the Nazi programme in Germany, sought to construct an ideal female identity: 'normal' women were to be mothers and home-makers. ${ }^{27}$ Food was a political issue. Endless queues for basic rations in France mobilised the female population. Demonstrations against food shortages have been identified as 'the first major challenge to public order facing Vichy' (Jackson 2001: 333). As Miranda Pollard states: 'for public opinion, there was a bottom line, and it was food. Women delineated this bottom line in an unusual reversal of political clout' (1998: 135). National and gender discourses of the period are inextricably linked, as Bertin's comments on a 1941 recipe-book Bonne cuisine quand même! reveal:

And so while we were informed of the best way to cook swedes 'in a wine sauce' or 'Normandy style', or 'peapod soup', we were also reminded about the 'débâcle' which we had brought on ourselves and the effort we had to make to save our homes and families. This Pétainesque moralising was quite unbearable and now even recipe books were full of it.

(1993: 317)

As was the case with clothing and make-up, the French deportees' discussing of recipes in the camps is clearly not just a question of reinforcing gender roles - women cook - but specifically (dictated) national gender roles: French women should know how to cook.

And if French women of the 1940s were meant to be culinary adept, official discourse also dictated that they be generally well versed in a whole gamut of domestic skills. After all, Vichy legislation of 18 
March 1942 made the teaching of domestic skills obligatory for all young girls (cf. Muel-Dreyfus 1996: 271; Pollard 1998: 80-4). The deportees, of course, found themselves in a radically different universe, and their desire and ability to conform to such norms of domesticity are represented, and can be interpreted, in a variety of ways. For some, the experiences of deportation served to inculcate a degree of conscious reflection about official discourses. Toulouse-Lautrec, for example, offers an ironic account of the 'ideal home' which was her prison-cell at Montluc:

American scholars have held a conference to come up with the model of the ideal home in which less is more.

We feel sorry for them. What more could you want than a surface area of two metres twenty by one metre seventy comprising: bedroom sleeping eleven, dining-room, living-room, sewing-room, kitchen, hall, waiting-room, private (bug)-hunting reserve and toilet. ... Everything within easy reach, no cupboards or furniture, in other words, low on housework, low on maintenance.

(1967: 40)

Le Guillerme reveals an awareness of imposed gender roles when she recounts her observation of her fellow-prisoners carefully sorting and washing clothes, and states: 'I'm a terrible housewife' (1946: 74-5). Brun's account of an incongruous attempt to maintain domestic order is both revealing and humorous. The deportees are about to board a cattle-truck which is due to transport them from Sarrebrück camp to Ravensbrück:

One of us exclaimed in horror: 'They're surely not going to make us get in there? I'm going to try and find a broom!'. Strange as it may seem our fellow-traveller came back with a German soldier and a broom, with a cheerful expression on her face.

(1979: 129)

Engaging in domestic activities, however, must also be interpreted in another light: the ability to mend and make clothes, maintain some degree of basic hygiene and indeed keep up appearances proved to be crucial survival strategies in the camps. The majority of accounts represent activities which doubtless helped both to maintain morale and to counter material exigencies: Lasnet de Lanty asks a French POW for thread and needles so she can mend her clothing (1965: 166); Schapira 


\section{Deportee identities I: gender/sexuality}

makes thread from blankets (1994: 89); Francine Christophe uses spare pieces of cloth as toilet paper, washing and re-using them repeatedly (1996: 83); le Guillerme records the making of extra clothing from blankets (1946: 70). Solidarity and morale were further strengthened by the making and offering of small gifts. Few of the deportee accounts reveal a reflective awareness that their domestic skills might have saved their lives. Birnbaum, however, points out that she tried to keep her clothing in as good a condition as possible precisely because personal appearance influenced the attitude of the guards: 'As soon as I started work sorting potatoes I realised that having clean clothes and looking neat and tidy greatly influenced those in charge' (1946: 87). ${ }^{28}$

It has emerged that the accounts reveal complex relations between official gender discourses and deportee attitudes. In some respects, the universe of the camps thwarted and countered the women's attempts to adhere to gender norms: female prisoners might, for instance, lose any sense of their gendered selves. In some cases the very situation they found themselves in seems to have heightened the women's awareness of gender and national norms; in other cases, they struggled to retain their sense of femininity and 'Frenchness'. However, while an aptitude for domestic skills and a fascination with compiling recipes reinforced official discourses, the desire to perpetuate a tradition of 'French elegance' in fact ran counter to official Vichy discourse. As Pollard points out, Vichy's elision of 'woman' and 'mother' was such that priorities in wartime France were altered:

Indeed, with femininity thus framed, anxieties about fashion and health so evident in pre-war advertising were eliminated. With food, clothing, and material of all kinds in such short supply, the duties of motherhood were more conveniently lauded than the desires of womanhood.

(1998: 49)

As the next section of this chapter will suggest, however, the deportees were unable to live up to the imposed norms of a 'womanhood' premised on maternal capacities.

\section{Motherhood}

Just as Nazi Germany emphasised the importance of children in its tripartite programme for women ('Kirche, Küche und Kinder'), so too Vichy set out to promote women's 'natural' role as mothers. It was under Vichy that the 'fête des mères' (then referred to as the 'journée 
des mères' [Mothers' Day]) became a national institution, and under Vichy that abortion laws were reinforced to a draconian degree: legislation passed on 15 February 1942 designated abortion as a crime against society, race, and the State; abortionists were subject to the same punishment as political traitors and thus potentially eligible for the death penalty (cf. Koos 1999; Pollard 1998: 174-94).

The situation in the camps could not have been more different. Until 1942 pregnant deportees in Ravensbrück were taken to local hospitals to give birth. Their babies were removed and the women were returned to camp. By 1943 conditions had worsened. Now women were pressured to have abortions, many of which were carried out in the camp. In some cases the birth was allowed to take place, but the babies were immediately killed. ${ }^{29}$ In 1944 a further change in policy reflected the changing fortunes of the war: most babies were delivered in camp, and by October 1944 a special block was designated for new-borns (Morrison 2000: 270). Between 19 September 1944 and 22 April 1945, 551 children were born in Ravensbrück, and entered into official records. Most survived for only a few days. Only three babies born to French deportees survived. ${ }^{30}$ The situation in Auschwitz was worse. Until mid-1943 pregnant women were killed by phenol injections (Strzelecka 1998: 405). Some, in the advanced stages of pregnancy were forced to have abortions. If babies were born, they were killed by phenol injection or drowned in buckets of water. Louria describes the birth of a boy to deportee Nathalie in Birkenau in great detail, noting that the child was immediately removed (1979: 126-7). Davidovici, who herself gave birth in Auschwitz, records her hazy recollections of being told by the Polish midwife (for whom she has nothing but praise) that it would be for the best if her baby were to die. Davidovici's only sight of her newborn child comes after the baby has been killed: 'He's been injected in the head and lies dead on the table' (1998: 47). Although the routine killing of babies stopped in the women's camp in June 1943 (the killing of Jewish babies, however, continued), most died of malnutrition or as a result of poor hygiene and sanitation.

Given these facts, it comes as little surprise that representations of childbirth and pregnancy are bleak indeed. As Lagrange and others note, women arriving in Auschwitz with babies or young children were immediately sent to their deaths: 'How could we ever forget those mothers holding the hands of young children they did not want to be parted from, singing to them softly to reassure them, probably knowing all the while that this was the end?' (1997: 51). Many deportees record the deaths of babies and, in some cases, new mothers. 


\section{Deportee identities I: gender/sexuality}

Aylmer-Roubenne describes the horrific end of a Polish woman dying from infection subsequent to a caesarean operation carried out in terrible, completely unhygienic conditions, with whatever instruments came to hand' (1996: 89), and that of a Russian woman bleeding to death from a miscarriage (ibid.: 90). Several deportees point out that in the absence of milk (very few women lactated and milk substitutes were often stolen by prisoner-functionaries), many babies died rapidly from malnutrition. Lagrange records the birth of a baby to a young French woman. The baby was hidden from sight but killed by a rat soon after its birth, precipitating the suicide of its mother (1997: 74). Busson also records the birth of a French baby - ironically named Marie-France Victoire - who was to die after only twenty days (1946: 105-7). Brun notes that some babies died as the deportees were evacuated from Ravensbrück to Bergen-Belsen. The mothers, hoping that they might have the opportunity to bury their children en route, secreted the bodies under their clothing, but were soon forced to abandon them by the roadside, unable to cope with even such a small burden (1979: 208-9). The lives - and deaths - of most of these babies are recorded only in these eye-witness testimonies.

Beyond their important recording of births and deaths, the accounts in some cases reveal ambivalent attitudes to maternity. In the light of the circumstances and the potential consequences of giving birth in the camps, the 'natural' state of motherhood was far from desirable. For Pagniez, the joys of motherhood are inevitably superseded by anxiety and fears of anticipated loss:

Who can imagine the suffering of the mother who leans over a cradle made of planks and bits of rag, who knows that her own flesh and blood, the child that you lift in your arms for the first time with such pride, and whose fragile life contains so many dreams, who knows that that young child can be taken from her at any time.

Reflecting upon the difficulties faced by a new mother during the journey to Auschwitz by cattle-truck, Schapira concludes that it might have been better if the child had not lived: 'Why was he born alive? Would it not have been better if he had never come into this world?' (1994: 54). Abadi, who describes the rapid birth and removal of a baby in Auschwitz, points out that the so-called 'maternal instinct' might be eradicated by the conditions which prevailed: 
As for me, I wanted to strangle the little runt who'd suffer all his life from the circumstances of his birth - if he survived at all! Suddenly, I become aware of something strange which amazes me: no one in the room has taken any interest in the birth. Even the maternal instinct, that primordial instinct which is even stronger among the Jews to whom children are so important, has been destroyed in these women.

(1995: 132)

Blanc similarly notes that though young children without parents could be found in Ravensbrück, many deportees (though rarely the French...) responded to their noisy displays with dismissive shouts (1984: 280). ${ }^{31}$ In other cases, the brutality of the system was brought home to the deportees by poignant reminders of maternal values. Elina describes the despair of those deportees ordered to move a group of prams left by a newly-arrived convoy in Auschwitz, the prams still warm from the bodies of the babies who had just gone to their deaths (1982: 19). For Lévy-Osbert, the truth of the extent of the killingmachine that was Auschwitz strikes home when she finds a baby shoe left by a Hungarian convoy (1992: 140-1). Aylmer-Roubenne records the horror experienced by a deportee working sorting clothes when she discovered a baby's hand in the sleeve of a garment (1996: 79).

Not only was motherhood in the very best of cases a perilous experience in the camps; for many deportees it was to be an experience denied them even after liberation. Although several deportees state that only the birth of their children marked the first steps towards recovery from the camps - as Mori-Perrin puts it 'That was when we really came back, when we brought life into the world' (1992: 157) the carrying out of so-called medical experiments in the camps often resulted in permanent infertility (when it did not kill the subjects). ${ }^{32}$ Sterilisations carried out by doctors Clauberg and Schumann (by the injecting of a caustic substance into the cervix in the case of the former; by X-ray and the excision of the ovaries in the case of the latter) are noted by deportee Adelaïde Hautval who worked alongside both men in Auschwitz. ${ }^{33}$ Both 'Capitaine Simone' and Valois record their subjection to medical experiments which resulted in infertility: 'Tragedy: we're going to be guinea-pigs! They're injecting us; they want to exterminate our race. Within a week they've managed to completely desiccate our bodies. Those injections have an unbelievable effect! I'll never be a woman again.' (Valois 1969: 70).

Such were the conditions of the camps that infertility could result even in the absence of such direct intervention. Francine Christophe 


\section{Deportee identities I: gender/sexuality}

(whose mother was also deported) reflects upon the destruction of her parents' dreams: 'Both of them dreamt of having another child. It would be a son, and they would call it Bernard. Mum used to say that her body needed another baby. Bernard never appeared because mummy was broken' (1996: 158). Tichauer points out in the penultimate paragraph of her account that she suffered a similar fate (1988: 170). For the female deportees the Vichy ideal of 'woman as mother' would have been ironic indeed, as would de Gaulle's patriotic (and patriarchal) post-war programme:

Women's specific contribution to the reconstruction of France was to be reproduction: General de Gaulle, as anxious about falling birth rates as his predecessors had been, called, in a speech made on 5 March 1945, for French women to produce 12 million bouncing babies for France in ten years.

(Duchen 1994: 29)

A bitter pill for those deportees returning to French soil unable to bear children, and thereby excluded from prevailing constructions of French womanhood.

\section{Conclusion}

It has emerged from the above discussion that contrary to the views of those who take a stand against 'gendered' approaches to the subject of concentration and death camps, an exploration of gender-specific areas of experience is crucial: without such an approach we are afforded only a partial view of life in the camps, and large swathes of material are inevitably occluded from history. The material above has, furthermore, provided an insight into how gender and sexual identities are constructed at a specific time and place, in very particular circumstances. Quotidian life in the camps undermined traditionally conceived gender roles and identities. While the Vichy regime sought to construct clearly demarcated gender roles, such delimitations were untenable in the camps. Hard physical labour, violence often perpetrated by women on women, enforced nudity, the shaving of hair, gynaecological examinations, the rapid physical deterioration of the female body, the absence of men - all these led to the 'de-feminisation' of the deportees. Such a process was, however, counter-balanced in some cases by a process of 're-feminisation' as deportees sought to redefine themselves as women, often becoming aware, perhaps for the first time, of the societal pressures which has previously dictated their gender identity. 
Crucial too has been the revelation of intersecting discourses at work in the construction of gender and sexual identities. As we saw, class played a key role in channelling (some of the) deportees' perceptions of those who volunteered for work in the camp brothels, and those who engaged in same-sex relations. Most striking, however, is the role played by national discourses. For the French deportees, sexual relations, whether heterosexual or gay, are almost exclusively consigned to the realm of the Other. French womanhood, furthermore, is premised primarily on an ability to uphold national reputations of domestic skills and elegance. The following chapter will explore the role of national, class and political identity further, revealing how such discourses lead to representations of various, often internally fractured, national groupings. 


\section{Deportee identities II Nationality, class, politics}

The previous chapter brought out something of the complexities involved in the analysis of deportee identities. Gender and sexual identities were seen to be constructed in the specific situation of the camps, and it emerged that differentiation is essential if an accurate picture is to be established: it is not enough to refer to 'women in the camps' though many studies do - but 'French women in the camps', and in some cases, 'French women of a certain class in the camps'. Of course (French) national and class identities are also constructs, and ones which will be explored further in this chapter, alongside an additional inflection: that of political affiliation. Although, for the sake of clarity, nationality, class and politics are treated as distinct categories in the following discussion, the extent of their implication in the construction of identity will once again become apparent.

\section{National identities}

\section{French on French}

In their self-representations the French deportees foreground a number of common traits which contribute to a construction of national identity, all of them, perhaps unsurprisingly, of a positive nature (or at least perceived as such by them). Many writers in the corpus emphasise the French nationals' reputation for a certain carefree light-heartedness coupled with a singular unwillingness to work. As two deportees put it: 'we French women, with a great reputation for frivolity and idleness' (Lorge 1992: 12); 'We had a knack of infuriating the Germans with our laughter: they could never forgive us that French spirit' (Simier 1992: 26). Recalcitrance in the face of enforced labour manifests itself in two favoured activities recorded in many accounts: the French deportees' exploitation of the status of the 'Verfügbar', and their aptitude for, and marked willingness to engage in, sabotage. 
Although the majority of deportees were assigned to specific labour-details, those who were not were expected to line up at the daily morning roll-call in the ranks of the 'Verfügbaren' (the 'availables'), to be picked out by Kapos requiring extra workers. In the eyes of the French deportees, avoiding work by remaining officially 'available' but slipping from the ranks became something of a daily sport. Maurice, among others, notes with pride that she and her friend Bluette would covertly join the ranks of the knitting detail or those who presented themselves at the hospital block as too sick to work, only to steal (or on occasion sprint) away and hide in the Blocks for the rest of the day (1946: 31-2). Such was the reputation of the French for avoiding work in this way that their tactics as elusive 'Verfügbaren' were to be inscribed in the culture of the camps. Toulouse-Lautrec mentions a short play written by one 'Coury' (actually Germaine Tillion) entitled 'The Verfügbar in hell' (1967: 273). Tillion's piece, described by her as a sort of 'light opera', opens in the fashion of a La Fontaine fable, with the lines: 'A poor Verfügbar picked out to go and work, / Bearing a heavy burden, past her prime, / Moaning, bent over, walking ever slower, / Tried to reach the hospital in time' (Tillion 1988: 160-2). In addition, Améry provides the words and score for the 'Song of the "Verfugbar"' [sic], which evokes similar work-avoidance tactics (1945: 28).

In the words of Toulouse-Lautrec the 'Verfügbaren' 'ruled supreme in the art of indiscipline, unreliability and sabotage by omission' (1967: 274). Sabotage, however, was not merely something carried out 'by omission'. Confronted with the unpalatable possibility of furthering the German war effort - especially when this involved working in armaments or munitions factories - the French, we learn, went out of their way to be as obstructive and indeed destructive as possible. Faced in Ravensbrück with an 'aptitude test' designed for those due to work in the Siemens factory, Améry, for instance, revealed herself to be sadly lacking in the prerequisite manual dexterity skills and apparently quite unable to pass a simple sight-test (1945: 85). Serre, working at Siemens (1982: 32), Crémieux at the Abteroda BMW factory (1999: 67), Benoist-Lucy at Ludwigsberg (1994: 91), Jeannin-Garreau at the Skoda factory near Holleischen (1991: 69) and Lasnet de Lanty on a plane assembly-line at Schönfeld (1965: 149), among others, record their acts of sabotage. The latter could assume many forms in different labour details. Crisimily, employed in a sewing detail, systematically ripped as many items of clothing as she could. As she and many others state: 'sabotage was our way of resisting' (1981: 133). 


\section{Deportee identities II: nationality/class}

Working for the Germans was deemed to be bad enough, but according to the accounts offers of payment in the form of bonuses which could be used in some camps to obtain supplementary rations or much-coveted goods such as toothbrushes, were beyond the pale. Several of the accounts insist that in an act of moral resistance the French consistently refused such payment: Jeannin-Garreau, at Holleischen, states all the French deportees refused bonuses (1991: 105) as they would not work for money on principle; Guyon-Belot points out that the 'food coupons' at Beendorf were similarly rejected (1990:188); London notes that French workers at the Hasag factory rejected the bonuses offered in exchange for increased productivity (1995: 340); Huk at Limmer camp states: 'We all refused extra food rations as payment for work. That way the SS couldn't say that we were volunteers' (1958: 150).

Sabotage in the workplace and the maintaining of a degree of integrity by refusing payment were typical manifestations of what is represented as the French deportees' general insubordination, which also revealed itself in ostentatious high spirits and what might be termed a deliberately fostered sense of national singularity. Améry explicitly represents the French light-heartedness and frivolity as an anti-Nazi strategy: 'A cheerful attitude is the best cure for Krautitis' (1945: 90). In apostrophic mode ('O! French fighting spirit!') Bouteille-Garagnon singles out the 'French panache' and 'light-hearted mockery' (1946: 125). Novac's comments on the French contingent suggest that their high spirits were also in evidence at Auschwitz: 'Their block is a real cure for depression' (1996: 222). The French capacity to laugh in the face of adversity was noted above in the discussion of humour where we saw rebellious laughter typified by responses to the dreaded 'shit detail' ('Come on girls, all together now, Let's shovel shit / and shovel it with glee' (Mori-Perrin 1992: 132)). Though the rules and strictures of the camps could not, of course, be entirely circumvented, a measure of subversive indiscipline could always be displayed. Several deportees report with some delight that the French refused to adopt the serried ranks of five and militaristic formations required of them. Brun, watching the work-details leave Ravensbrück from the quarantine block, notes that while the German prisoners marched impeccably, and the Russians and Poles with only slightly less cohesion, the shambolic French and Belgians revealed themselves to be the 'star turn', singing and marching out of step as a matter of principle (1979: 143). Guyon-Belot reports a similar phenomenon at Beendorf. Claiming that their chaotic marching arose from their unfamiliarity with the German marching songs they were 
required to sing, the French deportees struck up with nationalist ditties, and duly improved their style (1990: 174-5). For Blanc, such outward displays of ineptitude represented a crucial act of resistance:

Chaos is still the order of the day in the ranks of the French, who are intractable by nature. Nothing - shouts, threats, blows - has any effect on them. The day we form up in ranks the minute we are told to do so will be the day there's no bope for us. It will mean that the camp has beaten us and that we're devoid of any character.

(1984: 119, author's emphasis)

Given the widespread representation of French indiscipline and defiance, the recurring claim that the French were treated more harshly than their fellow-deportees makes considerable sense, and an element of rhetoric can be detected in the mixture of pride and bitterness which typify such allegations (if the French were truly so insubordinate, they could hardly be surprised by the response). Maurel and Serre are representative in their insistence that the French were singled out for harsher treatment: the former notes the familiar cry of the camp, 'What a surprise! The French are being punished again!' (1957: 60); the latter refers to 'an unbelievable regime of terror with its humiliating punishments suffered by us, the French, always treated worse than other national groups' (1982: 18). Interestingly, both Morrison (writing about Ravensbrück) and Sofsky (whose analysis embraces the whole network of camps) concur that the French had to endure particularly harsh treatment.

Morrison, who states that '[i]t is clear that the SS singled out the French for special measures', and that 'French women were assigned to some of the worst jobs', suggests that this may have been because a high proportion of the French deportees had been engaged in active resistance against the Germans in occupied France (2000: 95-8). Sofsky bases his analysis of the relative status of deportees on 'four hierarchically ordered criteria': race (the predominant criterion); geographic and national categorisation; 'political hostility' (towards the Nazi regime); and 'social deviance', to which he adds 'the most important formal and informal sources of power, namely the power to assign work and the social capital of the prisoners' (1997: 119-29). Sofsky's complex system results in an 'upper class' comprising the criminal prisoners and German political prisoners; an 'upper middle class' consisting of German asocials, Jehovah's Witnesses, Czechs and Northern Europeans; a 'lower middle class' comprising the Poles, French and Italians; and an 'underclass' made up of Soviet POWs, 
Jews, homosexuals, gypsies and Soviet civilians (ibid.: 122, 129). As the camps became more international in their community of deportees, he suggests, 'French prisoners were exposed to increased persecution and harassment', situated as they were in the middle echelons of the camp hierarchy, and as such struggling to maintain their rank (ibid.: 119).

Although neither Sofsky nor Morrison considers the deliberately obstructive attitude of the French as a contributory factor to their persecution, the surmise that the behaviour and attitude of the French contributed at least in part to the greater hostility they faced seems all the more likely to be correct when their self-depicted characteristics are examined in relation to other national groups. High spirits, indiscipline and a failure to work may have been seen as positive traits in the eyes of the French, but as we will see, this approach differed radically from that adopted by - for example - many of the Polish contingent, whose survival strategy seems in many cases to have been based more on outward compliance and quiet solidarity than open insubordination. The French deportees' representations of their own indiscipline and apparent indomitability reveal the complexities of identity construction. Although French attitudes and activities were designed to counter the power of the SS, the majority of such attitudes are represented in relation to recorded SS reactions. The self-image of the French, in other words, relies at least in part on confirmation from the SS. Representations of Nazi acknowledgement of French spirit runs through the corpus. Wilborts, for example, not only records the high French morale in the jail in which she was held prior to deportation, but the reactions of the 'Krauts', who, faced with loud singing in the exercise courtyards 'have no idea what to make of the French character, light as the air of this land' (1946: 46). Lesèvre similarly represents the French character via the words of the Nazi guards at Ravensbrück: 'They're French women, aren't they? Get rid of them. Look at their eyes; they're indomitable, somehow they still find a way to look down on us' (1987: 90). Lasnet de Lanty proudly cites the words of an SS supervisor: 'Those filthy Frenchies! Nothing affects them!' (1965: 88). In all of these cases we can detect the representation of another facet of the SS response - a certain grudging respect - which functions to establish the French not as inferior, but equal. This apparent need for validation of a national self-image is best reflected in Lahaye's report of the SS guards' response when a group of French women who had posed particular discipline problems left the camp: 
When we left Barth camp having been suddenly summoned back to Ravensbrück because of our fate as NN, they delivered a homily expressing (actually bellowing) their regret that we were leaving: 'Scheinerai! [sic]', they yelled at the other prisoners, 'The French were the only decent women in this camp.'

(1954: 28-9)

Outwitting the SS guards within the limited parameters available to them lay at the heart of a mode of resistance at which the French apparently excelled. One such endeavour was referred to in camp jargon as 'organising', a definition of which is supplied by Améry: 'in a word, making sure you are in a permanent, systematic state of potential insubordination... But also, and above all, it means stealing everything you can possibly steal from the Krauts' (1945: 118). Hugely proud of this capacity for 'organisation', Améry goes on to cite the words of one of the German guards, once more providing an admiring corroboration of the French self-image: 'The commandant of Romainville used to say: "Lock a naked French woman in a dungeon, and by the end of the week she'll need a suitcase when she leaves..."' (ibid.: 124). The words attributed to a senior SS guard by Corblet de Fallerans are very similar: 'No doubt about it, strip these French women and put them in jail, and they'll leave fully clothed' (1992: 136).

Stealing from the SS was regarded as an act of war worthy of praise, but stealing from fellow-deportees, especially one's own national group, was quite a different matter, and several accounts suggest that national superiority manifested itself in the French deportees' refusal to do so (other nationalities apparently felt no such compunction). Of course, this claim, and indeed all of those considered thus far, cannot be taken at face value. Representations of the French deportees' attitudes and behaviour are important to the extent that they reveal both how the French wished to be seen and the importance of claiming a national or collective identity. Although such representations may tell us how many of the French deportees behaved, a degree of hyperbolic generalisation and selective omission is inevitable. Some assertions are clearly incorrect, for instance, the not uncommon claim that no French deportee ever accepted a post as prisoner-functionary. ${ }^{1}$ The French contingent were no saints, and some accounts acknowledge this fact more than others, though representations of French shortcomings are few and far between. Giving the lie to the reiterated claim that the French never stole from each other, for example, Maurice admits that there were exceptions: 
She came from a good Parisian family; she'd had a privileged life, had always had everything she wanted when she wanted it; she was intelligent and cultured, well-read and well-travelled; but she'd developed a mercenary streak in the camp and she would have given anything to have enough to eat ... She used to sneak onto her neighbours' beds and was caught several times trying to steal from her friends.

Even here, the lapse in French moral superiority is mitigated: it is suggested that class plays a role (the mighty fall harder, those from the upper echelons of society have a weaker moral code); the camp has twisted the woman's mind; the fact that we are told that she was cast out by the rest of the French deportees reinforces the group's integrity (in both senses of the word). Maurice, furthermore, introduces the cited passage with a startling parenthesis - 'I remember S... (who was later gassed)' (ibid.: 54) - the perfunctory nature and indifferent tone of which come close to implying that the wrong-doer's come-uppance was deserved. As with this case, most acts which run counter to the French self-image are represented as exceptions which prove the rule. Departures from the French 'norm', especially those which extend beyond the maverick individual to include a wider group, do, however, appear towards the close of some accounts, where it is acknowledged that standards and spirits did indeed begin to flag and group solidarity wane.

There is, however, an exception to this French solidarity of representation, and it comes from the French Jews. Alcan, for example, reports that a French woman stole from the French (1947: 31), and refers to one Edmée (also French), who once elevated to the position of 'commando secretary' refused to speak to the rest of the group (ibid.: 48). Heftler notes that she herself stole a bowl from an old French woman, describing the act with some pride as one of 'organisation' (1992: 162). It is often the French Jews who offer poignant reminders of the moral dilemmas facing the deportees. Lévy-Osbert records the guilt she felt when the fear she experienced manifested itself in anger towards her friend:

Having been really scared I became really angry. A moment of catharsis. I blame her, I blame poor Thérèse, I blame her for her skeletal appearance, her neck which is too long, her body which is too scrawny, her emaciated face. I blame her and I forget what we should never forgot. That those who are really to blame are the 
murderers, the assassins, the contemptible creatures, the barbarians, the animals masquerading as human beings, the monsters, the members of the SS who have perpetrated so many horrors.

(1992: 163)

Maous points out that the French women who had been her friends were repelled by her state of near-collapse: 'These four women are hard and cruel; they don't like me, they're afraid of my suffering and the filthy state I'm in' (1996: 133-4). Maous is also open about her own moral decline:

I'm often cruel too. When, after a great deal of effort, I cross the block clasping that precious can full of warm soup, I go as fast as I can so that I can't hear the begging voices of my French companions ... I'm not proud of the woman I was at such times; nothing makes people cruel like real suffering.

(ibid.: 161)

The over-representation of French Jews among the ranks of those who question or undermine generalisations about 'the French character' comes as no surprise. Held in Auschwitz, they endured considerably harsher conditions that those faced by the deportees in Ravensbrück and its sub-camps, they were more isolated from other French nationals, and their national allegiance was, as we will see in the next chapter, in some cases tried to the limit by French anti-Semitism experienced both before, and in some cases during, deportation.

\section{French representations of other nationalities}

As the reflections of the French Jews remind us, conditions in the camps were such that altruism, the upholding of strong moral values and a sustained, spirited resistance may have been ideals, but they could rarely be maintained as quotidian realities. And if national solidarity itself broke down on occasion, then conflict among the different national contingents was inevitable. Deportees of various nationalities, speaking different languages, were deliberately barracked together. They responded to their situation in different ways, and were engaged in a perpetual struggle to maintain their place in the camp hierarchy. Many deportees were all too aware of the bitter irony of playing out racist or nationalist antipathies in the camps. As Fénelon states: 'Am I too going to start being racist? Racism here - how monstrous!' (1976: 196). Principle and practice, however, were often at odds. The French 


\section{Deportee identities II: nationality/class}

deportee accounts reveal a range of often powerfully expressed antipathies to other national groups, of which the two to emerge most frequently will be discussed here: the Germans, and the Poles.

\section{German nationals}

Representations of German nationals can be broken down into the following categories: SS guards; German prisoner-functionaries; other German deportees; the German population as a whole. Inevitably, the SS guards and German prisoner-functionaries, the latter usually criminals and a-socials, were almost universally loathed. A small number of French deportees acknowledge that some Germans in positions of power treated the deportees relatively well, but this is certainly not the norm. Representations of German political deportees are often more generous. Tichauer, for instance, explains how the latter improved conditions for all the deportees when they wrested power from the black and green triangles who held sway in the early period of the camps (1988: 94). Tichauer's praise, however, perhaps has rather more to do with politics than nationality: these Germans were Communists, and Tichauer later recounts how she herself became a Communist in Auschwitz. Brun sees beyond the national label 'German' to show support for the German political deportees: 'These men and women are our friends, I'm not afraid to use the word even though they are Germans, because to me they're fine people and they believe that it's better to die standing up than live on your knees (1979: 172).' Toulouse-Lautrec, however, struggles with her conscience when she is obliged to share a bunk with a German deportee: 'she's a German, said one voice, let her die, that'll be one less of them. ... But, replied another voice, she's a human being who's suffering, she needs help' (1967: 267).

Reactions to the German civilian population in the form of 'bystanders' are more unequivocal. Améry records a typical exchange as the French deportees return to Ravensbrück from Barth:

As we go past civilians stare at us with loathing in their eyes; children throw stones; on the station platform a pretty baby in its wicker basket smiles and smiles.

'If you were told to strangle that German baby, would you do it?' young Marie-Jeanne asked me.

'Yes,' I replied without hesitation, 'I'm too full of hatred.' 
Friang is incensed when the local population hides SS guards as the deportees escape from their convoy in the chaos of the last days of their incarceration: 'Their dear compatriots, those poor bullied-by-the-Nazisdon't-know-anything-about-all-the-horrors-of-the-concentration-camps carefully hid the poor SS guard being chased by those nasty young women' (1997: 136). The camps and those factories using deportee labour, she points out, dotted the German countryside, and could scarcely have passed unnoticed: 'Unless some seventy million individuals have been struck down by a case of collective amnesia' (ibid.: 137). Heftler expresses the joy felt by many of the deportees upon witnessing the bombed ruins of Berlin: 'I'd be lying if I didn't say how thrilled we were when we saw the state of the Great Berlin, capital of the great German Reich' (1992: 157).

Chapter 1 revealed that paratextual material in the accounts often targeted the German nation as potential threat, though we also saw that in some cases a retrospective distinction was made between 'Nazis' and 'Germans'. Diatribes directed against 'the Germans' and 'the German character' are not uncommon in the main body of the accounts. Bouteille-Garagnon, for instance, insists that 'the Germanic people have always had delusions of grandeur' (1946: 165), while Améry dedicates several pages to a quasi socio-psychological profile of the 'moral depravity' and 'sadistic cruelty' which typify 'the criminal German character' (1945: 48-51). For Améry, inherent national characteristics will inevitably emerge in a context where power can be freely exercised. Elma, a German arrested in France, soon 'reverts to type' once in the camp: 'Elma was soon to remember what nationality she really was. She soon stopped reacting like a French woman' (ibid.: 55). Saint-Clair, like Améry, comes to believe in a fundamentally flawed German nation:

Until now I've always distinguished between those who loved Germany before the war and those who loved it during the war. Today I regard the former as perhaps greater criminals than the latter, because they stood as advocates for a people they did not really know.

And where Saint-Clair looks to the past and invites her reader to reassess the German nation as it was before the war, Lesèvre suggests that 'the land of Goethe will be forever tainted by Hitler and his hordes' (1987: 115). Even in those accounts whose authors generally reveal moderation and a reflective analysis of the moral ambiguities 


\section{Deportee identities II: nationality/class}

which characterised the deportees' situation, anti-German feelings embracing the whole nation are often expressed with considerable virulence:

The person who has never gazed upon a pulverised Fritz doesn't know the meaning of the word 'sublime'! Their decaying carcasses were the most sought after since the world came into being; the earth thrilled at their rotting remains wherever they lay, and to even the most sensitive souls, their stench was like an exquisite perfume.

(Novac 1996: 318)

\section{'The Poles': the origins of international hostilities}

The French deportees' antipathy to (some) German nationals is understandable in the context, and it is worth pointing out that anti-German attitudes appear in most cases in those accounts published shortly after the end of the war. Equally widespread, however, are the acrimonious sentiments reserved for the Polish deportees, which cut across the whole span of publication dates. Given that the concatenation of reasons behind Franco-Polish hostilities typifies all international relations in the camps (and given also the limits of space here) the following analysis is intended to serve as a case study which reveals just how, and why, conflicts between nations might have arisen.

As was the case with attitudes expressed towards German nationals, dislike of the Poles is not a blanket phenomenon: the French acknowledge that there were 'good Poles' just as there were 'good Germans', though there is something of the 'my best friend is Polish' syndrome in this, and such exceptions tend to reveal other prejudices. Hatred directed at the Polish prisoner-functionaries must be distinguished from that directed at the rest of the Polish deportees, though the fact that a high proportion of functionaries were, in fact, Poles, did little to smooth international relations. Lévy-Osbert, who describes the Poles as 'more or less assistants to the Germans', and as characterised by 'wickedness' and 'a tendency to inform on others', concedes that there were (rare) exceptions (1992: 36). Maurel dedicates a chapter to Irena, a Polish Blokowa at Neubrandenbourg, who saved the French woman's life by forcing her to leave the hospital block just prior to a selection (1957: 145-8). In some cases the plight of the ordinary Polish deportees is recounted with considerable compassion. Pagniez records the desperate state of Poles arriving from Warsaw (1947: 56-8); Lasnet de 
Lanty tells the story of a Polish woman who lost her husband and children, also in Warsaw (1965: 152-4); Lesèvre recounts the tale of a Polish woman whose eight-year-old son was killed by the Nazis in horrific circumstances (1987: 109).

These exceptions notwithstanding, the norm in the accounts is one of widespread hostility. In some cases specific reasons are given for what is represented as a mutually felt antipathy between French and Polish deportees. According to Picard, for instance, the Poles' hatred of the French found its origins in France's failure to come to the aid of Poland when Hitler invaded (1995: 48). ${ }^{2}$ Abadi identifies another political motive for the state of tension between the two national groups: 'I was later to discover the origins of her unquestioning hatred for the French: she thinks France is to blame for all our suffering: Munich' (1995: 42). Maous, who claims that the Poles hate the French because they (the former) have been in the camps the longest, cites the words of a Polish woman who had been in Auschwitz for three years: 'During that time you French pigs were drinking champagne, well, now it's you who are going to snuff it here, and when the war is over, it'll be me who goes to the Champs-Élysées' (1996: 56-7).

The often powerful national antipathies expressed in the accounts can thus be traced back in some cases to resentment triggered by specific events or situations. Although many French deportees acknowledge the Poles' suffering as long-standing detainees, a qualifying 'but' usually accompanies such statements. The Poles apparently had shortcomings which simply could not be excused or explained by the length of time they had spent in the camps, as Birnbaum's words reveal: 'They had suffered a great deal before we arrived, but did that justify their tormenting us, did it justify their taking on the role of the Germans?' (1946: 65, my emphasis). Touboul points out in similar fashion that the Poles loathed the French and tried to terrify newcomers with accounts of the gas chambers: 'Suffering has made them hard and cruel, but I still find it hard to understand and forgive their determination to destroy us' (1982: 65, my emphasis). Améry focuses on another primary source of resentment: 'Although they endured the worst torments they held the most privileged posts in the camp ...' (1945: 35-6, my emphasis). Fabius, by contrast, adopts a more reasoned and analytic approach:

Some of our number disliked other deportees because of their nationality. The Poles, for instance, were not much liked. Why? Because they had arrived first and held the best posts and some even had cushy numbers in the hospital or kitchens. It was important to 


\section{Deportee identities II: nationality/class}

overcome this attitude and try to understand. Personally I always got on well with them.

The history of the camps reveals that the claims of both the Poles and the French were founded in reality, at least with respect to the length of time each had spent in the camps and the securing of favourable positions. Although constant movements between camps and subcamps and the fluctuating balance of different national groups is such that statistics can only be approximate, it has been estimated that the Poles in Ravensbrück outnumbered the French by approximately four to one, and in Auschwitz (figures for which are yet more problematic), by considerably more than this. Morrison (the first set of figures in the following list [2000: 86]) and Bédarida and Gervereau (percentages in parentheses [1995: 136]) identify the four principal nationalities in Ravensbrück as follows: Poles 24.9 per cent (36.76 per cent); Germans: 19.9 per cent (18.16 per cent, including Austrians); Russians: 15.0 per cent (21.25 per cent, including some POWs); French: 7.3 per cent (6.02 per cent). ${ }^{3}$ Piper gives the following statistics for numbers of deportees sent to Auschwitz: Polish Jews, 300,000; Polish non-Jews, 140,000-150,000; French Jews, 69,000; non-Jews (all other nationalities), 25,000 (1998: 68-70). The first Polish deportees arrived in Ravensbrück in the autumn of 1939, and by 1942 were the largest national group. By 1942-3 they had achieved 'an enviable level of power and importance in the camp', as signalled by the adoption of Polish terms such as 'Blokova' and 'Stubova'. The main influx of French deportees arrived in late 1943-early 1944, by which time the Poles were firmly established in the camp and had set up strong networks of mutual aid (Morrison 2000: 91-4).

The French deportees' dislike of the Poles can thus be explained at least in part in terms of simple envy of the latter's apparently advantageous position in the camps. They were also, as has been suggested above, in direct competition with the Poles, who occupied the same rung in the camp hierarchy. Other factors too, however, must also be taken into account. The French, as we have seen, took considerable pride in sustaining an attitude of visible, high-profile insubordination. The Poles, however, adopted a diametrically opposed approach to survival. As Morrison puts it: 'Outsiders might criticise the Poles for their "shocking attitude of submission" but their leadership had calculated that more power could be gained by keeping their heads down and engaging in "considerable co-operation with the German authorities"' (2000: 92). The fact that the French accounts constantly rebuke 
the Poles for their apparent passivity and compliance is more understandable once we realise that the two national groups adopted radically different strategies, and this becomes yet more evident if we consider attitudes to work. The French, as we have seen, avoided labour details whenever possible and engaged in sabotage at the least opportunity. Such an approach was wholly alien to the Poles, as various comments reveal. Bouteille-Garagnon records the anger of Poles working alongside the French, the latter's deliberate lack of productivity apparently resulting in reduced rations for both groups (1946: 210). Abadi states that the Slavs 'disdain all those who are not as strong as they are - the French, the metropolitan Hungarians, the Italians and the Greeks are no match for them' (1995: 47). Saint-Clair points out that 'primitive' national groups such as the Poles were used to suffering so fared better than other nationalities in the camps (1945: 129), while Renault refers to the 'Herculean strength' of the Poles (1948: 54).

Comments such as these reveal more than the fact that the Polish deportees' willingness to engage in hard work was inimical to the French. As Morrison points out: 'they [the French] were quite a diverse group, but unlike most of the other national components at Ravensbrück, including the Poles, there was a relative over-representation by the upper social classes' (2000: 95). ${ }^{4}$ Given this insight, it seems likely that the French also felt threatened by their own relative inaptitude for hard labour. As Gorce states, the French were considered to be lazy and unwilling to work, but were also, as she concedes, relatively incapable: 'even if we'd wanted to we couldn't have done the sort of heavy labour the eastern races did; they've been used to it since childhood' (1995: 139). Stressing the ability to avoid work and to sabotage - both activities which emphasise ruse and gumption rather than physical prowess - may well have amounted to making a virtue out of necessity. Descriptions of the Polish deportees as 'primitive' reveal furthermore that strong class prejudices inflected national antipathies. Maurel describes the Slavic nationals in the following terms: 'we came across a lot of strange creatures, brutish, bestial individuals quite incapable of thought' (1957: 42). She goes on to claim without a trace of irony - that while the Slavs crawled with vermin, 'needless to say we French women, officers' wives, journalists, teachers and the rest, did not have lice' (ibid.: 44).

The 'civilised' (French) vs 'primitive' (Poles) binary set up in (some of) the accounts is bitterly ironic. French categorisation comes dangerously close to replicating Nazi views of the Slavs as 'Untermenschen'. Polish society, unlike that of western European countries, remained 


\section{Deportee identities II: nationality/class}

hugely economically under-developed when war broke out. A census of 1921 had registered that 75 per cent of the population was based in rural areas, with 65 per cent working on the land, often in great poverty, a situation which was further aggravated by the Wall Street Crash of 1929 (cf. Davies 1981: 410). Hitler's 'pacification' programme in Poland led to mass relocation and deportation of the rural population. Little wonder then that so many of the Polish deportees were, indeed, 'peasants'. Class- and race-based denigrations of the Poles as 'primitive' are doubly ironic when we realise that the regime in the camps forced many French deportees to reassess just what 'civilised' might mean, though many failed to make any connection with their attitude towards other national groups. Commenting on the violent tendencies she herself experienced when faced with, for example, another deportee taking her place in a food queue, Crémieux states: 'when I saw what an effort I had to make to control myself, I realised just how thin the veneer of my upbringing was' (1999: 51). Tichauer and Brun concur: 'I learned that we can be reduced to fighting one another, that our civilisation is only a thin veneer which is all too easily worn away' (Tichauer 1988: 62); 'we are becoming real savages', 'How have we become so uncivilised?' (Brun 1979: 160). The wording of Brun's recognition that by the end of their time in Ravensbrück all tolerance among the French had vanished combines national arrogance with supposed self-questioning: 'we who are considered to be so civilised, who colonised the blacks' (ibid.: 187).

Of course not all of the Polish deportees were peasants, though the tendency to (over-)represent them as such is typical of the generalisations about nationality which can be found in many accounts. F. Christophe's overview, for example, depicts the Dutch as 'serious, hardworking and stubborn', and claims of the Greeks that 'their women cry with eastern excess' (1996: 79). Améry suggests that 'the Germans only think about having sex, the Poles about praying, the Russians stuffing their faces and the French sabotaging' (1945: 33). Novac and Abadi (both Jews) are more reflective, and more discriminating: 'Everyone in the block loathes the Poles. When everyone agrees, that's when I worry. I can't bring myself to like or hate indiscriminately and I never will' (Novac 1996: 78); 'They say "the Hungarians", making no distinction between illiterate peasants from the most isolated villages and those who live in big cities, who are often very cultured and speak several languages' (Abadi 1995: 106; this statement comes just after the recognition that 'on the whole people despise the Hungarians'). The fact that the Polish contingent embraced the whole social spectrum does not, in fact, go unnoticed by some of the French 
deportees, but their representations of educated middle-class Poles often reveal both class prejudice and, crucially, a powerful set of preconceptions.

Tillion comments that: 'There was such a big difference between a Polish student and a working-class Pole that they seemed to be of different nationalities: they had different ways of eating, of drinking, of speaking, of blowing their nose' (1988: 211). Whereas the 'working-class Poles' were wholly alien to the French (Tillion's articulation of this class difference in terms of nationality is a telling one), others were recognised by the French as potential kindred spirits, but only those who reinforced preconceptions of Franco-Polish relations. The connection between the two countries was a long one, dating back to royal marriages in the fourteenth century, thence to the Partitions of the eighteenth century, during which time the Poles came to see France as their truest friend in the outside world' (Ascheron 1987: 8). The 'Great Emigration' which followed the November Uprising of 1830 saw the majority of Poland's intellectual, cultural and political elite flee to France (ibid.: 26). Polish exiles made their way to France after World War II and sought to persuade the French to restore an independent Poland, a pattern which was to be repeated (unsuccessfully) with the formation of a Polish government in exile in Paris in 1939 (ibid.: 7, 91). This shared history clearly left its mark on the French deportees. Blanc describes the joy felt by the French when they first learned of the presence of Poles in Ravensbrück: 'we were overjoyed. After all, hadn't Poland always been a good friend to France? Were the Poles not all francophiles?' (1984: 115). Her discovery that 'cultured women' were - 'alas!' - a minority, came as something of a shock. Bouteille-Garagnon reveals similar romanticised preconceptions when she points out that the French had long adored Poland and its history of heroic struggles:

Poland with its heaths and silver birches, the chivalrous character of its great men and the struggles for freedom which led to so much bloodshed, the tenacity of its passionate and patriotic people and the infinite suffering which the Polish nation embodies.

(1946: 31)

She too is quick to point out that French expectations were soon to be dashed. Chombart de Lauwe makes a similar distinction. The educated Polish student whom she befriends is, in her eyes, the true representative of Poland: 'Diuba represented the Poland we were familiar with in France: patriotic, educated, enamoured of France' (1998: 92). Those 


\section{Deportee identities II: nationality/class}

Polish deportees who fitted the image, in other words, were readily accepted. Maurel refers in positive terms to Yanetchka, 'a cultured Pole', with whom she converses about literature (1957: 67). Gorce too is happy to make an exception for the educated middle-classes: 'Some very cultured Polish women who speak wonderful French tell us about their country, its culture and its artistic treasures' (1995: 64). The examples of sympathetic representations of Poles (all from Warsaw) singled out at the start of this section also fit into the category of 'educated Poles' (they were, moreover, late-comers to the camps, just like the French).

Not only do the accounts reveal the role played by class and preconception in Franco-Polish relations in the camps, they also show a degree of rhetorical manipulation on the part of some of the French writers. In several cases, direct speech is used to judge lower-class Polish women and reinforce notions of French superiority. ToulouseLautrec's reproduction of the speech of the educated Pole, Ewa, is typical:

The French are more advanced than we eastern races. While they were building wonderful cathedrals we were still clearing the forests. We are strong, young, robust, used to a life of hardship. The French have evolved beyond that stage.

(1967: 270)

So far we have seen that a range of factors affected Franco-Polish relations: specific situations in the camps (length of incarceration; the holding of privileged posts); opposing survival strategies; national preconceptions; class difference. One further and final factor comes into play and that is political affiliation. As was the case with respect to the social origins of the Polish deportees, only a minority of French accounts acknowledge the different political affiliations of the Poles. Where they do, sympathies once again, unsurprisingly, lie with those whose political views are aligned with those of the French writer in question. Tichauer points out that there were socialist and Communist Polish deportees with whom she established a good understanding, but dismisses the rest as 'nationalist, Catholic and anti-Semitic' (1988: 119). Améry, once more employing the device of direct speech - using one faction of the Poles to condemn another - sets up an opposition between the apolitical, compliant Carla and the anti-fascist Estoucha, who states: 'Carla does not represent the real Poland. We, the people, are the real Poland!' In response to Améry's question 'But how do you explain your compatriots' attitude?', Estoucha replies: 
But they're fascists too, Pilsudski's lot. They may be anti-German in Poland, but here they become, or remain, what they always were: fascists. They're all princesses, society women, teachers and officers' wives. Not one working-class girl, not one peasant. We hate them too. Above all, we're ashamed of them.

$(1945: 110-11)^{6}$

What emerges most clearly from all that has preceded is that hatreds expressed in nationalist terms often mask other motives and indeed prejudices. It is equally clear, and indeed a something of a truism, that difference - whether of social origin or political belief - was more likely to provoke hostility than sameness. When Picard established a strong bond with three Italians, it was partly because each spoke a little of the other's language, but more significantly, because all shared the same level of education and had similar cultural interests: 'But also because we speak the same language in the figurative sense' (1995: 81). And if speaking the same language in metaphorical terms was important, then so was a literal ability to communicate. Roux, barracked alongside German deportees, initially experienced nothing but extreme hostility and even physical violence. Once the language barrier began to break down, however, relations improved and a strong Franco-German alliance was formed (though the belief in French superiority is still clearly visible in her words): 'I've made some progress with my German. They've made some progress with their manners. Result: we're friends' (1946: 47). Placed in a work detail alongside Russian deportees, Roux discovered that a similar linguistic and cooperative breakthrough could be achieved: 'It's amazing how you end up confiding in one another in russo-franco-anglo-esperanto-latinogermanic pidgin!' (ibid.: 54). Roux's successful forging of international friendships, however, proved to be short-lived, and her account serves as an important reminder that prejudices and hostilities could all too easily re-emerge. Once she returned to a predominantly French block, her open-minded (if patronising) attitude towards other national groups underwent a dramatic metamorphosis:

Further off, opposite our block, bright in the harsh light, is the great bazaar, the native district where people brawl non-stop, the ring in which they tear each other's hair out, the seedy hotel with its undercurrent of pilfery, shady deals, and robbery. It's the farmyard full of yapping and whining; the harem with its endless petty squabbles; the landing stage in Aden when the steamboat arrives, a miasma of mosquitoes, antechamber to the land of witches... I 
could go on. And that's just the half of it. In a word, it's that part of the block reserved for our 'sisters in captivity', the Russians and the Poles.

(ibid.: 182)

The last word on the subject will be left to a Polish deportee, Lewinska, who points out that what may be a positive trait in 'ordinary life' - nationalism - could all too easily become a monstrosity in the camps:

So it is that the word 'patriot', such a fine, generous word, ended up in camp jargon meaning fanatics for whom insults like 'yid', 'Ukranian pig', 'Polak' etc. ... became an outlet for all the bitterness they'd stored up in their wounded hearts.

(1945: 151)

\section{Class identities}

The impact of class difference on international relations has already emerged, but what of its potential effect on the cohesion of the French contingent? Tillion states:

What struck me personally about the French contingent compared to other nationalities was its homogeneity. ... I would defy any stranger to distinguish between a Parisian student and a Parisian working-class woman in their striped dresses.

(1988: 211)

This partial (not to mention Paris-centred) view is a little misleading. It is quite possible that non-French deportees were unable to distinguish between students and manual workers from the capital, but an outsider's perception of similitude and harmony can mask internal discord, and, indeed, the accounts reveal that many of the French deportees themselves were neither blind to, nor forgiving of, the different social origins of their fellow nationals. Class-based fracturelines split 'the French' contingent.

Hostilities often arose prior to deportation as French resistants found themselves incarcerated in jails throughout France alongside a heterogeneous body of women, including criminals ['droits communs'] and prostitutes, both of which groups are often represented in tones of considerable animosity. Huk, typically, responds with horror to what she describes as the 'filthy comments' and 'obscene gestures' which 
abound among the prostitutes (1958: 15), referring in tones of undisguised disgust to one semi-naked woman's belly-dancing and singing of bawdy songs (ibid.: 17). Toulouse-Lautrec reports the disdainful response of her cell-mate 'Madame R.' to what she perceived as the vulgarity of her fellow prisoners, pointing out in typically laconic manner that once 'Madame R.' became 'acclimatised' to her surroundings and learned to laugh at the smutty humour of those around her, she seemed thirty years younger. As she puts it: 'Madame Rossinante has been liberated' (1967: 95). Paul suggests that the prostitutes held in Rouen jail were consigned to the bottom of the hierarchy by all classes of French prisoners:

Sometimes prostitutes were put in our cell for two or three days. All the women, whether they were factory workers, typists, maids or fine ladies, looked down on those poor girls. No one actually said anything to them but it was worse than if they had done.

(1962: 70)

Those imprisoned for other criminal acts were equally despised, as much for their social status as for their criminal activities. Brun points out with heavy irony that her stay in the prison cells of la Roquette and Rennes taught her a great deal about drug abuse, pimping, theft and fraud. Antipathy in this case at least seems to have had as much to do with Brun's perception of the coarseness of her fellow prisoners as with their criminal activities, as her description of Ida, a criminal, suggests: 'she oozed vulgarity and degeneracy from every pore' (1979: 27). Surrounded by women arrested for anything from armed theft to vagrancy to the carrying out of illegal abortions, Huk comes to the conclusion that these criminals are so very different as to constitute an alien species: 'If we want to understand how a common criminal behaves, we have to change the way we think about morality. ... To understand these strange souls we must completely realign our way of thinking. These women are abnormal' (1958: 42). De Loulay, who was detained in Fresnes alongside a number of criminals, casts herself in the role of victim: 'I'm ignored and mistreated, called a "little princess", laughed at because I'm so inept when it comes to carrying out certain tasks' (1945: 40). It is with some considerable relief that she points out that once she left Fresnes for Romainville the social mix was more to her liking: 'the standard has risen a little' (ibid.: 49).

In many respects, the conflicts which arose in jails prior to the deportation of the French women is understandable: for many prisoners this was their first glimpse of another, often less privileged 


\section{Deportee identities II: nationality/class}

world. Even a less extreme social mix was, as Jeannin-Garreau. observes, unprecedented: 'They would probably otherwise never have met: the factory worker from the north, the aristocrat from Versailles, the Parisian student and the artisan from the south.' Jeannin-Garreau's claim that social difference was erased in the camps - 'Living as they do here in the same misery, the same reduced state, with all social differences erased, the essence of human relationships was laid bare to them' (1994, unpaginated) - is rather idealistic. For a significant number of the French deportees, social differences within their own ranks were to remain an insuperable barrier in the camps.

Comments revealing class prejudice made by the authors of the accounts themselves are not widespread in the corpus, although they certainly exist and should not be ignored. Le Guillerme, for example, eavesdropping on a conversation held by her friends (including the 'Countess de Rochefoucault'), finds the register of the exchange offensive: 'This is most certainly not the sort of language she would have used in civilian life: the camp is beginning to have its effects' (1946: 111). As she points out (admittedly with some disapproval), categorisation based on class took place even within individual blocks which were often split into two 'sides', 'A' and 'B': 'Side B is apparently somewhat less select' (ibid.: 127). Le Guillerme adds that there was some movement between the two sides: Arlette de Montlaure, from 'side A', sometimes played bridge in 'side B', and it was not unknown for the ladies of 'side A' to visit 'women who were quite delightful, in spite of their living in the inferior zone' (ibid.: 127). Differences in social status cut both ways. Le Guillerme records an exchange which took place as she was transported from Ravensbrück to Zwodau alongside many 'of the most vulgar gossips who ran the show in side B'. When talk turns to the toilet bucket, and the language becomes crude, le Guillerme asks her travelling companions to desist, only to be greeted with the reply: 'Ah! it's one of the fine ladies from side A...' (ibid.: 163). Bouteille-Garagnon refers with considerable distaste to a group of French women discussing the relative merits of different brands of champagne (1946: 240). During her transportation to Ravensbrück de Loulay appears to yield to the majority as she joins in the obscene songs of the prostitutes with whom she travels (1945: 50), but once in the camp she is quick to rejoin the ranks of her 'little clan of "aristocrats"' (ibid.: 76). Busson too suggests that the novelty of the company of prostitutes in Ravensbrück soon gave way to disgust in the face of their vulgarity and lack of education (1946: 128).

Although there is a certain reluctance to put one's own signature to class prejudice and snobbery, the corpus reveals a not uncommon desire 
on the part of the deportee writers to signal the presence of such attitudes among their fellow French. Fabius, for example, who moved in high social circles prior to her deportation, acknowledges that her (aristocratic) friend Tatiana de Fleurieu behaved in an exemplary manner at Ravensbrück but that no one ever dared to employ the familiar 'tu' form when addressing her (1986: 163). Other fellowdeportees were apparently more blameworthy than de Fleurieu. Fabius states that 'Countess F.' (arrested for black marketeering) refused to clean her own canteen in Fresnes 'on the pretext that she'd never done the washing-up in her life' (ibid.: 139). Once back in Paris, Fabius shocked the assembled guests at a dinner-party when she pointed out that the same countess was obliged to work in Ravensbrück (ibid.: 73). Fabius further records the attempt of one French woman to gather together a petition asking that those 'belonging to the aristocratic set' be grouped in a special block so that they might avoid having to live in close proximity to certain French fellow-deportees whose company they found more than a little painful (ibid.: 184). Fabius's response - 'I couldn't help intervening and asking them if they hadn't heard of the "abolition of privileges"' - fell on deaf ears (as indeed did the petition).

For some deportees social status was something to be maintained and respected at all costs, irrespective of the new context in which they found themselves. As Elina puts it: 'People are at pains to tell you about their previous station in life so that you treat them accordingly' (1982: 40). Bouteille-Garagnon targets those she refers to as the 'socialites' and the 'clan of society women': 'By means of clever flattery some of them tried to make contacts just as they would have done in a cosy social gathering' (1946: 102). Dufournier echoes the view, and suggests that denial was clearly at work in some cases: 'They try to make up for their present ills by recalling their past glories, often a little exaggerated thanks to a slight manipulation of the truth; they cling onto the past and refuse to change their set of values' (1945: $160)$.

The deportees' response to the unfamiliar social circumstances in which they find themselves is often somewhat ambiguous. De Loulay describes her apparent acceptance of her new status with a healthy dose of inverted snobbery: 'I'll be honest: being immersed in vulgarity, assailed by coarseness, was not an unpleasant experience. I shed my intellectual pretensions like an old skin' (1945: 103). Fabius's account is marked by a similar ambiguity and ambivalence. On the one hand, her description of her pre-deportation resistance activities and her encounter with 'the indescribable low-life of Marseilles' smacks of condescension: 


\section{Deportee identities II: nationality/class}

In some respects these people, whom I would never have dreamed of approaching if it hadn't been for the war, were quite interesting. They even showed a human warmth of the sort rarely encountered in my usual circles. Maybe I too have a vulgar side, albeit unconscious or unexpressed.

Fabius does, however, choose to open her account with a moving tribute to an unknown woman who helped her carry out the hard labour required of her when she first arrived in Ravensbrück, and comes to question her carefree previous life-style which had led to her placing value on 'trivial details of society life', a superficial side to her character which she acknowledges is the privilege of 'those who have never really had to struggle to get where they are' (ibid.: 18).

In other cases the learning process is unequivocal. Crémieux readily admits that she and other "young women from so-called "good families"' learned a great deal from those around them (1999: 68). Learning to rid oneself of class prejudice could assume a different form. Crémieux's notes taken in 1946 record her irritation upon discovering that 'Madame de B.', who had plagued her fellow-prisoners on the journey to Ravensbrück with continual references to her aristocratic status, did not have her head shaved upon arrival (ibid.: 34). Looking back on this incident over fifty years on, Crémieux recognises that her views were those of a 'rebellious adolescent who had for a while been active in the Communist Youth', and that 'Madame de B.', who had played her part in the Resistance, 'turned out to be completely different from the stereotypical view I'd had of her' (ibid.: 35 ).

The ability to 'see differently', to break out of a mind-set which was no longer valid or viable, could be crucial for survival. As Huk points out, social rank had to be reconceptualised in the camps, where social status was a function of one's behaviour (1958: 155). A failure to adapt and cast off old social identities could prove fatal. Abadi refers to a primitive system of justice' in the new world of the camps, and claims that those deportees from the highest echelons of society soon learned that their previous status counted for little, and that their failure to accept their changed circumstances led to a spectacularly high mortality rate (1995: 39). Class distinctions belonging to the 'old world' which had been left behind by the deportees were superseded in the camps by a new hierarchy, described by critics and deportees alike in terms of a metaphorical class system, a new order in which individual behaviour and attitude were by no means the only, or even the principal, factors involved. 
Tillion, who, like Sofsky, chooses to describe the social hierarchy of Ravensbrück in terms of class divisions, places the prisoner-functionaries (of whatever nationality) firmly at the top of the social ladder:

The difference between the relatively opulent life-style of a member of the camp police or of a Polish, Czech or German Blockova and that of the French rabble to which I belonged was a great as the difference in the standard of living of the Queen of England and those who frequent the London night shelters.

(Tillion 1988: 187)

The deportees also conceptualised the camp hierarchy in terms of class. Indeed, the camps are described by many as reverting to the autocratic rule and rigid social stratification of a feudal system. Novac points out that no sooner were prisoner-functionaries chosen from among the ranks of ordinary deportees than "new "dynasties" and "courts" were established' (1996: 260-1). Those placed in such positions of power soon assumed a monarchic role, acknowledging the 'rabble' from which they had newly emerged with 'a little regal wave of the hand', receiving the congratulations of the camp leader 'with a sort of natural dignity bestowed upon them as if by divine grace' (ibid.: 260). In an inversion of normative class markers outside the camps, those deportees working in the kitchens are singled out by several deportees as forming part of the camp 'aristocracy'. According to Abadi, those in the sewing detail and administrative sections also belonged to the camp 'nobility' (1995: 105), to which category Saint-Clair adds the nursing personnel (1945: 93-4). Others conceptualise the metaphoric class system in different terms. De Gaulle-Anthonioz refers to the 'under-class' - 'the destitute, the ragged, beaten for no reason, liable to be worked into the ground' (1998: 43); Abadi to the "starving proletariat" in the blocks' (1995: 105); Maurel to the 'schmoustiques', those "who coped as best they could, rummaging through the rubbish, washing without soap, killing their lice when they had the strength to do so, stealing, begging and dying' (1957: 41). ${ }^{7}$ Far from constituting a united body, the deportees lived in a world subject to ever more minute social divisions and stratification. The kitchens may have housed the camp 'nobility', but as Toulouse-Lautrec suggests, even here clear distinctions were drawn: 'The kitchens have their own aristocracy. We are the plebs' (1967: 234). Alcan points out that the relatively privileged Raisko commando (itself an 'aristocracy' in the eyes of other deportees) also had its own hierarchies: 'the women working in the "Pflanzensucht" are snobs. They look down on those 


\section{Deportee identities II: nationality/class}

working in the "Gaertenerei". It's ridiculous, in fact it's monstrous' (1947: 70). Alizon concurs, stating that in Raisko the 'aristocracy' comprised the biologists, chemists and agricultural engineers, while the technicians working in the fields as she did occupied an altogether lower social rank (1996: 263).

Social divisions in the camps - both those which carried over from the pre-deportation world and those which arose in the new context of the camps - cut across international and national groupings of deportees. In the hierarchical world of the camps the deportees could always find someone below or above them on the social ladder. Occasionally, both sides of the divide are revealed. Heftler expresses anger in the face of the privileges enjoyed by members of the Auschwitz orchestra: 'The members of the orchestra were ad hoc musicians; anyone who'd ever held a mandolin claimed to be a musician because it was a cushy number' (1992: 78). Fénelon, who had a place in the orchestra, was well aware of the privileged nature of her position: 'The double rank of pitiful wretches I have to pass through makes me uneasy. I don't know if those women look at us - I don't dare meet their eye.' In spite of her claim, Fénelon is well aware of the mutually defining gaze which links the two groups - aristocrats and common people. As the latter shout and direct looks of hatred at members of the orchestra like a prerevolutionary rabble calling for bread, Fénelon is shamed: "To us they are the "Others". A terrible phrase. I think about them, I'm obsessed by their existence, I feel as though they strip me of my right to be warm, clean and properly dressed' (1976: 72-3). 'The "Others"' is, of course, the key phrase, revealing as it does the manner in which oppositional identities were forged throughout the camps. Prior to deportation, in the French jails, the 'Other' against whom certain of the French contingent sought to define themselves had to be drawn from among their own ranks (prostitutes, criminals). Once in the camps, the deportees may initially have struggled to forge a social identity based on their previous life, but were soon obliged to accept their new status in an externally imposed hierarchy. As we have seen, nationality and 'race' played a key part in this new social system, but so too, to a lesser extent, did political affiliation.

\section{Political identities}

\section{'Politiques': the red triangle}

In the context of the camps the term 'political' had two distinct meanings. First, it designated all those who were assigned a red triangle by 
the Nazi administration. This included all the French female deportees with the exception of those identified as Jews. In other words not all the French 'political deportees' were - as some might perhaps assume - involved in Resistance or Communist activities. Jeannin-Garreau indicates that the red triangles among whom she was deported included prostitutes who had infected German soldiers (1991: 46). Guillemin Ducret observes that although the majority of her convoy were resistants, the remainder consisted of volunteer workers punished for criminal acts $(1986 ; 73){ }^{8}$ In fact, the Nazi-imposed category of 'political' was broad indeed, embracing all those deemed to be opponents of the National Socialist régime: resistants, Communists (the two are not, of course, mutually exclusive), criminals of all shades, prostitutes and madams, black marketeers, hostages, volunteer workers and individuals seized in raids.

The vast majority of the non-Jewish deportee writers whose accounts are being considered here were deported for their Resistance affiliations, but not all. As the title of her account - Déportée pour une injure - suggests, Lorge was arrested and deported for having insulted a group of German soldiers (1992: 1). Simier explains that she was unaware of the motive for her arrest and deportation and that of a small group of fellow-teachers (1992: 13); Mallet points out that one of her cell-mates awaiting deportation was arrested when a 'maquisard' took shelter (uninvited) in her home (1949: 13). Unlike Lorge and Simier, Tubeuf-Branchu (arrested for being in possession of a gun) is positively eager to disassociate herself from the Resistance:

Dear reader, I'm sure you are anxious to learn why I was deported. Put your mind at ease, I committed no crime. I did not belong to any political party which might have troubled the occupying forces. I quite properly had nothing to do with the Resistance.

(1962: 9)

Her antipathy towards the Resistance is clear: 'After all, did it not sometimes give the occupying forces the excuse they needed to carry out bloody reprisals on innocent people, thereby justifying their barbaric methods?' (ibid.: Foreword). Although such sentiments among the general public were probably more widespread than is often assumed, ${ }^{9}$ Tubeuf-Branchu is the only writer of the corpus to express such open hostility, though several writers register similar attitudes among prisoners awaiting deportation. Toulouse-Lautrec records an exchange with her cellmate Madame Rossinante, member of the 'Catholic League of French Women', who when asked if she was in the 
'maquis' replied: 'Certainly not! They are worthless individuals, riffraff, maybe even worse than the Krauts. The Krauts, at least, were decent.' Toulouse-Lautrec was quick to riposte: 'Madame Rossinante, I have the great honour of informing you that you find yourself in the midst of a predominantly terrorist element' (1967: 93).

Anti-Resistance sentiments, however, are rare. Much more widespread is a combination of pride not untainted with a certain sense of exclusivity as those women who had been active in the Resistance, angered by the Nazi-imposed blanket term 'political' - a category which they believed rightfully applied to them alone - once more defined themselves in opposition to other French women (those bearing the same red triangle). Several deportee writers insist that the 'true' political deportee could be easily distinguished from the mass of other French deportees destined for the red triangle. According to Huk, the very manner in which women entered a prison cell for the first time was a clear indicator of their status. While the criminals invariably wept or cursed: 'The political prisoner is completely different. She is proud and calm. She makes a careful entrance. She stands for an ideal, she knows why she is there and is not ashamed of the fact' (1958: 41). The true political deportee represented solidarity. She had fought, and was prepared to die for, an ideal, traits which were (apparently) sadly lacking among the other deportees. As Brun states in proselytising manner of those women taken as hostages or seized in raids: 'These women don't know the meaning of solidarity, of the one and indivisible community from which we draw strength, they can't see beyond their miserable little lives, and at their age trying to educate them is so difficult!' (1979: 123).

As de Loulay suggests, once in the camps, membership of the Resistance élite meant setting an example to others: 'Me, a true French women! A political prisoner! As if I'd let myself go in front of these criminals, these whores!' (1945: 177). Generalisations such as these, pertaining to the moral status of various groups of deportee (are we to believe that only - and all - 'official' resisters showed national solidarity and spirit?), become yet more problematic when distinctions take on a racial tone. Friang, for instance, insists that while the true political prisoners at least took a stand, 'members of various ethnic groups, Jews, Poles or Russians, who'd been seized in raids across whole regions' remained resigned and passive ('In such cases the idea of a collective malediction, or a judgment from God can hold people back', 1997: 105). Mori-Perrin takes this already potentially racist generalisation a step further: 
There are at least a hundred of us, maybe more, silent in our despair. With us are women seized as hostages, mainly Jews of all ages, brutally separated from their families, they are crying and wailing it is unbearable (they will not return). It is different for us, we have fought, we have an ideal and that helps us to maintain our dignity.

(1992: 91)

As the next chapter will reveal, such oppositional constructions of identities on occasion led to, and were symptomatic of, a more generalised anti-Semitism.

\section{'Politiques': attitudes to the Communists}

If we narrow our conception of the term 'politiques' to Communists and those who had been active in the Resistance, the representation of conflicts arising from difference is greatly reduced, but by no means wholly eliminated. By 1944 - the year in which the majority of French women were deported - disaggregation and open conflict among the various Resistance factions had decreased considerably, and the accounts do not differentiate between, say, movements and networks, or the Resistance presence in the North and South of France, nor is much made of potential conflict between de Gaulle's Free French and internal Resistance forces. ${ }^{10}$ One Resistance faction, was, of course, to remain problematic in terms of the cohesion of 'the Resistance' throughout the war and indeed after the Liberation: the Communists. ${ }^{11}$ Anxieties and antipathies arising from the presence of Communist deportees are played down by some deportee writers. Tillion claims that national allegiances played a much greater role than political solidarities, and that the vast majority of French female deportees were apolitical, a fact 'which contributed to their ability to get on with members of the "Party"' (1988: 211). Maurel suggests that in spite of the presence of many Communists and many others who feared Communism, 'for most of the time the French women put politics aside. If they could help someone they did, irrespective of their political leanings' (1957: 41). In fact, the picture which emerges from the accounts is not quite so harmonious. The French Communist deportees are singled out for adverse comment in a significant proportion of the accounts.

Certainly some French deportee writers reveal a positive attitude towards Communists - though nearly always those of other nationalities - focusing particularly on the solidarity and mutual aid these 
women displayed. Abadi, for example, singles out the Yugoslavian 'collective': 'In this camp [Auschwitz] where everything is for sale, where women fight each other like animals over a piece of bread, the Yugoslavians allow nothing but camaraderie and solidarity in their block' (1995: 135). Jeannin-Garreau, a Gaullist, notes that the Communist deportees always sought each other out, set up cells, and extended their support to those outside the Party (1991: 84). De Gaulle-Anthonioz points out that she herself was helped by the Communist 'international committee' in Ravensbrück (1998: 40). Representations of the French Communists tend to be more ambivalent. At the very least, their presence and solidarity with non-Communists are clearly regarded as an issue worthy of mention and discussion. Aylmer-Roubenne chooses to stress unity, suggesting that the Communists could readily be embraced under the umbrella term 'Gaullist': 'I can say with no exaggeration that the French resistants, including the Communists, were Gaullist. ... At the time our Gaullism had no political connotations' (1996: 56). The question 'What are you?', asked of all new-comers, invariably elicited the response 'a Gaullist', deemed to be sufficient proof of the interlocutor's credentials. Toulouse-Lautrec also opts for a picture of solidarity, though she approaches the issue from a different direction, and cannot resist pointing out that her Communist colleague is wrong-headed in her ideology, if well intentioned. Commenting on a fellow-prisoner's use of the word 'comrades', she affirms:

No, it isn't a Communist, it's a French woman ... who has somehow got into our cell and starts to argue the pros and cons. She's an optimist because she manages to find a 'pro'. The word comrades seems strange, but in captivity we are all comrades.

$(1967: 180)^{12}$

Several writers are quick to focus on the 'late arrival' of the French Communists to the patriotic cause. Le Guillerme represents a heated discussion concerning 'their love of the International as opposed to their love of France' and belief that 'in former times their country meant nothing to them' (1946: 174). Bouteille-Garagnon makes a similar point: 
'Adrienne, what percentage of Gaullist resistants are there in our convoy compared to Communists?'

'Wait a minute, are you saying that the Communists aren't resistants? I dare you to say that again...'

'Of course you are, since 1941 anyway; better late than never.'

(1946: 54)

Friang concedes that the French Communists, like their nonCommunist fellow-prisoners, are in the camp because of their principles, and that for this reason they 'share the same blood'. However, she qualifies this picture of national solidarity with a reminder of the Nazi-Soviet non-aggression pact, and describes the Communist 'change of heart' in a decidedly sceptical and ironic tone:

Since the Soviet Union, initially on Hitler's side, has become his sworn enemy, they [the Communists] have forgotten their little hiccup and have taken on the spirit of resistance. They even believe they were the first resistants. And it's true. You just have to specify who they were initially resisting.

(1997: 210)

Others are more openly hostile. Bouteille-Garagnon, who uses the words 'extremists/extremism' as synonymous with 'Communists/ Communism' throughout her text, focuses on what she perceives as the Communist plans for post-war political hegemony: 'One thing was clear from all this: the extremists had hoped that on account of their resistance against the Nazis they would be able to impose their totalitarianism on France after the liberation. They were disappointed' (1948: 31). Communists are represented as hopelessly idealistic figures who, drunk and deceived by a dangerous ideology, mistake 'dictatorship for true freedom, state control for the fulfilment of humanity' (ibid.: 48).

The Communists were not only criticised by some for their opportunism and political naivety; they were also seen to be attempting to 'contaminate' their fellow-deportees with propaganda. BouteilleGaragnon expresses hostility in the face of the French Communists' attempts not only to form a cell but to proselytise (1946: 194-5). ${ }^{13}$ Although she is largely positive about the Communists' willingness to help those of any political conviction (or none), Blanc nonetheless draws the line when faced with the Communist Marinette, 'a typical Marxist agitator', whom she accuses of attempting to take over the camp 'in order to establish a Soviet' (1984: 184). It is clear from 


\section{Deportee identities II: nationality/class}

several accounts that the French Communists did indeed attempt to recruit their fellow-deportees to the Party. In some cases, they were successful. Tichauer, who found herself in the Communist-dominated Raisko commando at Auschwitz, notes: 'my political convictions have changed a great deal while I've been in the camp' (1988: 120). Under the influence of figures such as 'Marie-Elisa' (whom we can identify as Marie-Elisa Nordman, part of the famous 'convoi du 24 janvier'), ${ }^{14}$ Tichauer underwent a secret ceremony and entered the Party in the autumn of 1944 (ibid.: 212).

Attempts on the part of the French Communists at Raisko to recruit and politically educate were not always regarded in such a favourable light. Alizon, herself a part of the same convoy, and one of only twelve Gaullists in that convoy, confesses that - like Tichauer she had previously been wholly politically ignorant, and that her arrival 'in the midst of one of the most intense centres of Communist intellectual activity' (1996: 99) resulted in the group's taking upon itself to educate her (ibid.: 277). Admiring of the Communist group's solidarity, she nonetheless balks at the brutal means often employed in the name of raising political consciousness, citing the French Communists' insistence on telling a Jewish girl that her mother has been gassed (ibid.: 219). Alizon further accuses the Raisko Communists of being hierarchical and clannish; of looking out for their own to the exclusion of other, non-Communist deportees, and of refusing to communicate information about Allied advances to those regarded as 'imperialists' (ibid.: 266, 277).

The Communists based in Raisko are not alone in eliciting accusations of this sort. Maous describes her increasingly fraught relationship with 'Marie-Jeanne' (probably Marie-Jeanne Bauer, another member of the convoi du 24 janvier), whose ineluctable spirit and willingness to die for the cause seem ultimately - and ironically - to have precluded the fundamental human trait of compassion. When Maous, who unlike her Communist compatriot was not in a 'privileged' work-detail in Auschwitz (Marie-Jeanne had secured a place in the sewing detail), falls prey to despair, friendship quickly turn to contempt: 'Is your little life worth more than those of tens of thousands of Russian soldiers who are dying every day? Do you feel sorry for them? No, you only feel sorry for yourself' (1996: 75). Douhéret criticises the exclusivity of the Communists at Ravensbrück, where national solidarity apparently once more took second place to ideological accord:

I have to say that my idea of solidarity was cruelly undermined by the behaviour of one fellow-deportee. ... Marie-Claude Vaillant- 
Couturier was looking after the sick in the hospital block. Dédée went to ask her if she could give her some pills for me. 'Is she a Party member?' she asked Dédée. Obviously Dédée said no. 'Well, I don't have any', she replied. I was horrified by this behaviour. We were all in the same boat, fighting for the same cause: France.

$(1993: 44)^{15}$

And mutual aid could, it would seem, assume a more pro-active form. Friang points out that thanks to the attentions of the communist support system' at Ravensbrück, she was selected for a transport to Zwodau (and, it was believed at the time, to certain death) in the place of the Communist whose number had originally featured on the list (1997: 120). Lahaye expresses similar sentiments in her semi-fictional Les Rachetées (1963). French Communist Claire (referred to as 'the little Stalinist') is happy to see a non-Communist stand in at morning rollcall for a fellow-deportee risking transportation, but would, apparently, balk at such a risk being taken by one of 'her own' (ibid.: 101). Like Alizon, Lahaye highlights the irony of a Communist group which had, in her view, betrayed its own ideology: 'Far from being a revolutionary force, Claire and her loyal followers had become the camp bourgeoisie ... They had ended up more attached to their privileges than to action' (ibid.: 118).

Hostile representations of the French Communists reveal various tensions and conflicts. First and most obviously, that between nationalism and Communist ideology, encapsulated in Saint-Clair's description of her return to France. Upon hearing railway workers singing the International at Lyons station, Saint-Clair urged her fellow-deportees to respond with a chorus of the Marseillaise. As SaintClair puts it: 'At the same time, on the same station platform, men were asking: "What should we shout? Long live Stalin, or long live de Gaulle?" An officer answered: "It's obvious, shout long live France"' (1945: 201). This response, based on the subsuming of one term of the conflict (Communism) under the other (nationalism), is, however, far from satisfactory, though it is symptomatic of the problematic fracturing of potential solidarity in the camps, where class, political and national differences often led to ever-decreasing circles of solidarity and exclusion. Where one might have expected to find a centripetal force uniting the deportees, one often actually discovers a centrifugal movement towards dispersal and disharmony.

This exclusionary fragmentation serves to reveal a second, and more fundamental conflict at work in the camps, again revealed through the negative representations of the French Communists. On the one hand, 


\section{Deportee identities II: nationality/class}

anti-Communist sentiments expressed in the accounts must be read with a measure of circumspection: the political convictions of nonCommunist writers obviously inflected their representations of a group whose motives and ambitions for France they held to be deeply suspect. But attacks on Communists were not, of course, the sole preserve of non-Communists. On 12 November 1949 former deportee David Rousset caused uproar in the PCF (French Communist Party) when he called upon his fellow-deportees to take a stand against the Soviet camps, while criticisms levelled at the Buchenwald Communists, accused of deliberately selecting nonCommunists for transports to work camps, added fuel to what was already a conflagration. ${ }^{16}$

In his recent study of the writings of French deportee Robert Antelme, Martin Crowley identifies these incidents, and Antelme's response to each, as challenges to conflicting conceptions not only of Communism, but of solidarity and community themselves (Crowley 2003: 47). Crowley argues that Antelme's attempts to reconcile the lessons he had learned in the camps with the Party line reveal the deportee as a potential precursor to contemporary attempts to reconceptualise community:

Essentially, this entails efforts to think community as other than self-present, defined not by the exclusionary force of shared, positive attributes, practices or belief, but in terms of radical inclusivity, grounded impossibly in an exposure, a fragility which determine community as spaced.

(ibid.: 38)

The voices of those who suffered from precisely the sort of exclusionary solidarity and community against which Antelme (according to Crowley) stood are there to be heard in the corpus of accounts. As we have seen, national and class solidarities, the French Communists' protection and promotion of their own, and resistants' repeated appeals to an 'ideal' which they claimed as theirs alone, all constructed fractured communities of deportees which effectively excluded all 'non-members'. As Colbert de Fallerans puts it: 'everyone tried to situate themselves in terms of social rank and political affiliation. Groups were formed, held together by intangible bonds of affinity, but those who were left out felt very alone' (1992: 121). Brun's resistancecentred reference to 'solidarity, the one and indivisible community' (1979: 123) reveals her own circumscribed conception of community. Of course, there are exceptions. At least some of the deportees articu- 
late a more ethical, humanist stance which, like that of Antelme, could be said to herald a more inclusive conception of community. One might, for example, cite Lahaye on the subject of the Communists at Ravensbrück: 'A man can glorify a party, but a party cannot glorify a man' (1963: 120).

One final point remains to be made, and it is one which both returns us to the opening chapter of this study and opens the way to the next. Rousset's case, and the repercussions it triggered, feature in another text: Todorov's Les Abus de la mémoire. For Todorov, Rousset's appeal for an investigation of the Soviet camps typifies the sort of 'exemplary memory' which should prevail over 'literal memory' (Todorov 1998: 42-50). ${ }^{17}$ Rather than instrumentalising memory in an attempt to reinforce specific identity groups (Jews, resistants, Communists, French nationals, etc.), the lessons of the camps must, Todorov insists, serve an ethical, future-oriented project which aims above all to avoid further degradations of the human community. Interestingly, Todorov's critical analysis of memory in Les Abus de la mémoire had already been adumbrated, albeit in a different form, in his earlier Facing the Extreme (2000; first published 1991), in which he differentiated between 'heroic' and 'ordinary' virtues, and between 'solidarity' and 'caring'. In the case of each opposition the first term ('heroic virtue' and 'solidarity') is regarded as exclusionary. As Todorov puts it: 'To act out of solidarity with a group is a political, not a moral, act' (ibid.: 84).

Strikingly, Todorov suggests that women consistently displayed 'ordinary virtues' and 'caring' more than their male counterparts. The material that has emerged in this chapter, however, paints a more complex picture. As we saw in Chapter 1, many deportees do indeed end their accounts with inclusive, humanitarian appeals in keeping with 'exemplary memory'. However, as this chapter reveals, the camps in fact proved for many women to be hostile territory for such an inclusive praxis of community, for the flourishing of 'ordinary virtues' (though here too we should be wary of generalisation). In order to illustrate the exclusive nature of solidarity - 'Solidarity with our own implies the exclusion of all others. Its victims are foreigners, strangers, those who are different' (Todorov 2000: 82) - Todorov singles out the wartime treatment of foreign Jews at the hands of the French (both Jewish and non-Jewish). As we will see in the following chapter, expressions of anti-Semitism in some accounts illustrate his point all too clearly. 


\title{
5 Deportee identities III
}

\author{
Jewish identities
}

Distinctions between accounts authored by Jewish and non-Jewish deportees have been drawn in the preceding chapters only in cases of marked specificity or difference, whether in relation to the texts themselves (for example, the late clustering of Jewish-authored publications), or to the construction of deportee identities (Jewish deportees' representations of the moral integrity of the French were, for example, seen to differ from those of non-Jewish deportees). In many respects similarity outweighs difference, bearing out Wieviorka's suggestion that francophone texts written by Jewish and non-Jewish deportees have much in common (Wieviorka 1994b: 30). There are, however, greater differences than Wieviorka suggests. Some ten years on, a more extensive corpus of Jewish-authored texts is available, including accounts by Abadi; Alcan (two texts); Asseo; Birnbaum; Christophe F.; Christophe M.; Crémieux; Davidovici; Elina; Fabius; Fénelon; Grand; Grinspan; Heftler; Hollander-Lafon; Holstein; Lagrange; Lévy-Osbert; Louria; Maous; Marmor; Ourisson; Picard; Schapira; Tichauer; Touboul. ${ }^{1}$

An analysis of this expanded corpus in what follows allows us to avoid the by now familiar pitfalls of essentialisation: we can no more generalise of 'Jews in the camps' than 'women in the camps'. It is, however, important to acknowledge that the Jewish authors considered here cannot be described as wholly representative of Jews deported from France. It has been estimated that at the start of the war approximately 135,000 foreign Jews and 195,000 Jews of French nationality were living in France. Of these, some 56,000 foreign Jews and 24,500 French nationals did not survive (Klarsfeld 1978: unpaginated; Zuccotti 1993: 3, 216). ${ }^{2}$ Not only are all the accounts in question here francophone; they are all authored by French nationals. Accounts written by foreign or 'stateless' Jews deported from France - accounts which are likely to have been written in Yiddish or other non-French languages - have thus, unfortunately, been excluded from this study. 
Imposed identities: Jewish Otherness and specificity

Constructed difference prior to deportation: state antiSemitism

'The Jewish Statute is promulgated by Vichy and appears in the Journal officiel of 18 October [1940]: we become outsiders, outcasts' (1994: 17); 'we had been arrested because we were Jews, because we were not like other people! ... But it is they who have just made us "different"' (1997: 44). Thus, Schapira and Lagrange respectively sum up the manner in which the Jews of France were constructed as Other and marginalised. This imposition of identity recognised no distinctions, bringing together under one label - 'Jew' - the religiously observant and the secular, those steeped in Jewish culture and those wholly ignorant of it, those who could trace their French roots back over several generations and those from recently arrived immigrant families, those who identified as Jews and those who did not. Not only was Jewish identity officially dictated by the two 'Jewish Statutes' of 3 October 1940 and 2 June 1941; those thus labelled were obliged to register as Jews, to signal their presence by wearing the Star of David, and to ensure that their official documents were stamped 'Jew'. Deemed paradoxically to be both too different yet apparently threateningly similar to the rest of the populace, the Jews were to be rendered publicly visible. As Grand puts it:

I had straight fair hair, the palest of pale eyes, the classic Ashkenazi mug, in other words that of an eastern European, in other words, the same as everyone else's. So it was a matter of some urgency that those targeting specific looks should adjust their sights so that my deceptive physiognomy might be identified, and for that there was only one possible tactic: the star.

(1996: 24)

Unlike accounts written by many non-Jewish deportees, the majority of Jewish-authored texts open not with the dramatic moment of arrest, but rather on the preceding period during which their authors had endured the material and psychological effects of state anti-Semitism, providing us with details all too easily lost to history. Schapira, for instance, registers the added insult meted out to Jews as the Star of David they were obliged to wear was deducted from their clothing ration (1994: 24). Visibility had to maintained at all times: when Holstein removed her jacket on a hot summer's day, carrying it with the Star of David prominently displayed, she spent the afternoon being 
questioned in the local Feldgendarmerie, before finally being instructed that 'if you take your jacket off you must have the Star of David on every item of clothing' (1995: 27). Being visibly marked out as Jews for the first time proved to be especially traumatising for the young. Christophe informs us that her Star of David practically obscured half of her eight-year-old frame, and that she forced herself to maintain dignity in the face of curious stares from her peers: 'since I have to be Jewish I'll be Jewish with a smile, without betraying my fear' (1996: 20): Grand found herself in a daunting minority in the school playground: 'Two little girls wearing their labels, unsure whether to strut around, die of shame or wet their knickers with fear' (1996: 29). A minority of women, including Fabius, refused to wear the Star of David on the grounds that their identity as French citizens should prevail: 'Why should we have had to wear a badge which set us apart? We were French, and the rest of the French population was not marked out in this way' (1986: 68). For Lévy-Osbert, the refusal to be visibly identified served to mark her and her three colleagues out from the mass of Jews in Drancy, and indeed to underscore the ambiguity of her relationship to the Jewish community: 'They are all wearing the yellow Star which the four of us have avoided until now. What discrimination! We feel like strangers among our own people' (1992: 91).

Visible markers of difference and discriminatory measures of course extended further, as basic civil identities and rights were removed. Abadi records that she was forced to stop practising as a doctor (1995: 16), Tichauer that she had to abandon her university studies in medicine (1988: 39). The shop in which Touboul worked was taken over by an administrator and many of her colleagues sacked (1982: 13). Contravening regulations, Birnbaum remained at work in her business premises, but had to place the concern in a friend's name (1946: 13-14). Schapira's father was removed from his business which was taken over, while his daughter was expelled from her school (1994: 20). Jewish pupils were instructed to remain at the back of the classroom and forbidden to come up to the blackboard (Holstein 1995: 26). Lagrange records a dramatic change of heart in her teacher: 'before, she had admired my dark curly hair; now she declared that I must have lice, that I smelled, like all my Jewish classmates' (1997: 12). Such attitudes are not uncommon: several accounts record the manner in which 'friends' turned away either through prejudice or fear, banning their children in some cases from playing with Jewish children. AntiSemitic measures impinged on all aspects of daily life. Christophe refers to the curfew for Jews, adding that she found herself excluded 
from public places such as museums, theatres, gardens, cafés and cinemas (1996: 21). As a sports devotee, the young Holstein was devastated to discover that she no longer had access to public tennis courts (1995: 27). Schapira reminds us that Jews were permitted to occupy only the last wagon in the metro, and to buy food only between certain hours (when few goods remained) (1994: 18).

Given the gamut of measures which inscribed discrimination onto the fabric of everyday life, it is unsurprising that for many Jews, 1940 proved to be the year in which they felt 'different' for the first time: 'As soon as the Occupation began I realised that a little Jewish girl was no longer quite like other little French girls' (Holstein 1995: 17). Difference had not been a factor prior to 1940: 'I had never felt that I was any different from the other children' (Lagrange 1997: 11); 'At school I'd never been made to feel that I came from somewhere else' (Grinspan and Poirot-Delpech 2002: 26). Thereafter, Jews were constructed not just as different, but inferior. Many accounts emphasise the unremitting presence of anti-Semitic propaganda. Schapira recalls a notice in a local shop window: 'Beware: LISSAC is not ISAAC' (1994: 22), posters in Paris depicting France being swept clean of dirt - the 'dirt' in question consisting of figures bearing the Star of David (ibid.: 19) - and notices advertising an exhibition promising to instruct the public in how to recognise Jews: 'they portrayed the Jew with protruding ears, thick lips, and a weaselly face' (ibid.: 20). Holstein points out that propaganda extended to all media: 'All day long the radio proclaims that the Jews are subhuman, dirty ... that they're vermin which must be exterminated' (1995: 28). Although, as she recognises, such propaganda was extraordinarily crude, its psychological impact was nonetheless insidious: 'it inevitably ends up having a certain effect, it colours people's attitudes' (ibid.: 28). Several writers subjected to anti-Semitic images at a young age record a process of internalisation: 'I've discovered that I'm Jewish, that I'm a monster and that I have to hide away' (Christophe 1996: 23); 'Eventually no one needs to tell you that you're less than human, you feel completely subhuman' (Grand 1996: 17).

Once raids began across the country it became imperative for Jews to become invisible. For many authors, the moment of arrest came after months if not years of hiding and constant movement from one location to another, the material hardships of a clandestine existence compounded by the constant terror of denunciation and discovery. In a chapter entitled 'Afraid of one's own shadow' Asseo describes how she sought to persuade a local Catholic priest to add her children to the parish register, how nuns agreed to take her daughter into hiding but 
not her son (the risk was felt to be too great because the child was circumcised), ${ }^{3}$ and how she was finally obliged to leave both her children with strangers, before going into hiding herself. Touboul, who relocated from Marseilles to a village in the Hautes-Alpes, was forced to return to the city when one villager grew suspicious: 'the hunting season was open, and I was the prey' (1982: 13). Davidovici's family found themselves moving constantly from one town to another, living in increasingly poor conditions (1998: 9). As Grand, who was sent away from Paris in 1942, puts it with bitter irony, this constant movement was such that many came to resemble the stereotypic image of the 'wandering Jew': 'If the coat of arms of the House of France is the fleur-de-lis on an azure background, then that of the House of Jews is a skew-whiff old suitcase tied up with string' (1996: 51).

It will have become clear that in marked contrast to political deportees, many of the authors with whom we are concerned here were deported at a very young age. Being a minor was no protection once one had been labelled 'a Jew'. Francine Christophe was arrested aged 8, Lagrange was 13, Grinspan and Novac 14, Heftler and HollanderLafon 15, Schapira 16 and Holstein 17. Children were often separated from their parents. Christophe notes the presence of large numbers of unaccompanied children in Drancy (1996: 34). Schapira cites a letter she received from Pithiviers camp from her 12-year-old brother, arrested alongside her parents but left to fend for himself when they were deported (1994: 34). Schapira was herself later deported from an UGIF orphanage, as was Holstein. ${ }^{4}$ The age-span of those who survived to write is, of course, tragically significant. The very young were usually killed immediately upon their arrival in Auschwitz. Separated prior to their arrest or subsequent to it, Jewish families were split apart and many children discovered that they were orphans when they returned from the camps. The moment of 'happy reunion' to be found in many of the political deportees' account is rare in the case of Jewish authors. Schapira, Holstein, Grinspan and Lévy-Osbert never saw their parents again. Abadi discovered that her mother and sister had died in Auschwitz. Heftler's father was selected for the gas chambers on arrival at Auschwitz; her mother died in the camp shortly afterwards. Louria's father died in camps; no family awaited her on her return. Tichauer's father died in Auschwitz; her mother was selected for death on arrival. Lagrange lost her sister. Her nephews, aged five and seven (described by the author with bitter irony as 'two little "footnotes", 1997: 13) $)^{5}$ were deported alongside her father, who was killed before her eyes several months later in Auschwitz; her mother had died shortly after arriving in the camp. For those deported young, 
childhood was savagely curtailed. As Hollander-Lafon states: 'How could I ever forget the huge flames rising from the crematorium, flames which consumed my childhood?' (1977: 70).

As the above list reveals, Auschwitz was the destination for the vast majority of French Jews, ${ }^{6}$ and all were deported from France as 'racial' deportees, irrespective of the fact that many were resistants. Jewish identity, in other words, took precedence over any other, a fact which is reflected in the accounts themselves. Although a significant proportion of women mention their resistance credentials (Abadi, Alcan, Crémieux, Fabius, Fénelon, Lagrange, Lévy-Osbert, and Marmor), in many cases this potential identity is elided, or at least minimised. Fénelon, for instance, mentions only in passing that she had received and passed on documents and hidden people in her home (1976: 29); Marmor states almost as an aside that she had joined 'a major Resistance network' (1990: 88), and that her piano concealed false identity cards (ibid.: 91); Abadi briefly mentions in the opening pages of her account her involvement in the 'Marcel Network' set up by her partner Moussa Abadi, but does not revisit the subject. Strikingly, only one text - that of LévyOsbert - replaces the usual introductory pages stressing anti-Semitic measures with detailed information relating to her political allegiance and activities, in this case in a Communist youth organisation. LévyOsbert typifies the French-identified Jew (see below) who makes little mention of her Jewish identity, but even she signals the gap between an identity which she herself assumed (resistant) and that imposed upon her (Jew) when she indicates the motive for her arrest: 'guilty of having been born into a Jewish family' (1992: 90).

As Abadi suggests, those who were arrested 'while engaged in Resistance activities and who were sent to Birkenau because they were also Jews' found at least some answer to the question 'why me?': 'they fought against the Nazis and the Nazis punished them for doing so' (1995: 38). Those who were not resistants struggled to accept the consequences of the (imposed) label. Lévy-Osbert's ironic reference to guilt is echoed by others: 'What have I done? What misdemeanour have I committed? Who have I wronged? I'm twenty years old and I have my whole life in front of me' (Touboul 1982: 22-3). In many cases Jewish identity is represented as an inescapable fate which has led to unjustified and incomprehensible consequences: 'There was no reason for my arrest. I was arrested only because I was born a Jew' (Grinspan and Poirot-Delpech 2002: 197); 'why did I have to pay such a high price for being a Jew?' (Lagrange 1997: 141); 'God don't let me die! Don't let me die so young, just because I'm a Jew' (Birnbaum 1946: 72). 


\section{Deportee identities III: Jewish identities}

\section{Difference in the camps: Auschwitz and Ravensbrück}

Constructed as 'Other' prior to their deportation, and deported as 'racial' prisoners irrespective of their perception of their own identity, the Jews of France who left Drancy for Auschwitz were to face very different conditions from the political deportees who found themselves in Ravensbrück. But to what extent is this difference brought out in the accounts? Do Jews and non-Jews comment on the specificities of their respective situations? And how are Jews represented by French political deportees?

Were one to read only the accounts written by political deportees, one could easily lose sight of the difference between a camp which was primarily a concentration and labour camp (Ravensbrück) and one which was both a death camp and a concentration/labour camp (Auschwitz). Many of the accounts authored by political deportees mention 'black transports [transports noirs]', the feared 'Jugendlager', and the gas chambers of Ravensbrück. 'Black transports', which dispatched those prisoners deemed to be unfit for work to camps with gas chambers and to locations such as the 'institute for euthanasia' at Bernburg, began in December 1941 and continued until December 1944 (Tillion 1988: 239-44). A significant proportion of the Ravensbrück accounts mention these transports, usually (and unsurprisingly, given that no one - evidently - had first-hand knowledge of the facts) in somewhat vague and on occasion ill-informed terms. Le Guillerme, for instance, records a conversation which took place on March 1944, as a group of French political deportees in Ravensbrück watched a convoy of trucks pass by:

'Don't look, don't listen, it's a "black convoy".'

'So you think black convoys really exist?'

'Yes. Marie Bortnowska and all her friends are talking about them... When people leave in the middle of the night it's a bad sign, especially when they leave in trucks... They're being taken to the gas chamber.'

(1946: 137)

And if several accounts mention the gassing of deportees in the context of the 'black transports', yet more refer to the 'Jugendlager' or Uckermark camp. Situated approximately one kilometre from Ravensbrück, the 'Jugendlager' (so called because it had previously functioned as a detention centre for girls) was, as of January 1945, the destination for those women given a 'pink card', indicating an incapacity for work (cf. Tillion 1988: 252-7; Morrison 2000: 286-9). 
While many died of malnutrition and as a consequence of the appalling conditions, others were sent from the Jugendlager to the Ravensbrück gas chamber, built at the end of 1944 and in operation until the end of April 1945 (cf. Tillion 1988: 258-77; 329-60; Morrison 2000: 289-91). Morrison emphasises the secrecy surrounding the construction and operation of the gas chamber (ibid.: 289), ${ }^{7}$ but lack of first-hand knowledge did not preclude widespread awareness of its presence. Saint-Clair, for instance, records her conversation with a fellow French deportee:

'I've also been told they're building a gas chamber.'

'Well, if you will listen to all the camp rumours!... I've heard that it's a new room that's going to be used to disinfect clothing.' $\cdots$

(Dear Colette, you were too optimistic!)

Tubeuf-Branchu states that the gas chamber was located behind the crematorium (1962: 19). Jeannin-Garreau, who left Ravensbrück for Holleischen in April 1944, records her good fortune: not only were conditions in Ravensbrück to worsen considerably over the following months; a gas chamber would be built (1991: 58). De Loulay, similarly, notes that those deportees who returned to Ravensbrück from Torgau faced probable death: 'The gas chamber, the crematorium..., nine out of ten of them won't survive' (1945: 119).

Of course the fact that the political deportees stress these aspects of Ravensbrück is entirely understandable. It is nonetheless important that a fuller picture of comparative conditions be acknowledged, and that the specificities of both Auschwitz and Ravensbrück emerge. Whereas the Ravensbrück gas chambers functioned for some three months, gassing at Auschwitz took place between the late summer of 1941 and November 1944 (Piper 1998: 157-82). ${ }^{8}$ Unlike Ravensbrück, selection for death in Auschwitz, as of 1942, began as soon as deportees set foot in the camp. What was for the political deportees arriving in Ravensbrück a moment of terror and incomprehension was, for Jews arriving in Auschwitz, quite literally a life and death situation. Age, gender - and luck - played a crucial part. Holstein survived because she reluctantly submitted to a prisoner's incomprehensible warning ('I think he's crazy') to dissociate herself from the young children with whom she had travelled (1995: 51). Thirteen-year-old Lagrange's life was saved when a prisoner signalled to her mother that she should pass her daughter off as 16 (1997: 50). 


\section{Deportee identities III: Jewish identities}

Many were separated on arrival. Lévy-Osbert, whose close friend Rosette was led off in a different direction, expresses the incredulity felt by all when the significance of this early selection emerged: 'So Rosette is burning, Rosette has gone to be gassed. This can't be happening...' (1992: 97). Lagrange, who watched as three young girls, Marcelle, Claudia and Minna, were led off to their death, expresses similar disbelief when she learns the truth: 'It sounds so insane that we can't really believe it's true' (1997: 62). The smell of burning bodies which pervaded the camp soon served to bring the reality home. Heftler, finally, informs us that she survived because she looked older that her years and her mother younger (1992: 33).

Surviving the initial selection was only the first step. The Jewishauthored accounts remind us that selections - 'That awful word, the word that meant death' (Touboul 1982: 75) - were frequent, plunging all into a state of constant terror. Although those unfit to work were the primary targets, a certain arbitrariness certainly prevailed, as Birnbaum suggests: 'Depending on the whim of the day, fat women or thin women, dark- or fair-haired, the ones they like the look of, or they don't like the look of' were selected (1946: 22). For those in Auschwitz, death by selection was not something heard of second-hand nor was it an event which struck unknown others. Elina records the disappearance of her close friend Hella in stark terms: 'I never saw her again. The Germans took her away and burned her' (1982: 66). Both Birnbaum and Alcan refer to the loss of French lives during a selection which took place on 27 April 1944 in the hospital block. Abadi, working as a doctor, was instructed to draw up a list of those patients unlikely to recover within a fortnight. In spite of her attempts to falsify diagnoses, and to try to persuade the incapacitated to rise from their beds when Mengele carried out his inspection, many of her patients were selected for death (1995: 63-7). Many of the authors record how they themselves narrowly escaped selections in the camp. Touboul, thought to be under the age of 16 because of her emaciated state, was pulled from the ranks of the daily roll-call only to be reprieved when the guard was persuaded that she was 22 (1982: 69-70). Louria narrowly escaped selection when hospitalised for severe ulceration of the foot (1979: 189).

Reading accounts written by those in Auschwitz and those in Ravensbrück side by side highlights the differences in conditions which prevailed in each camp, but to what extent are these differences recognised by the authors themselves? Certainly the opportunity for comparison existed for some deportees even prior to their liberation. As of mid- to late 1944 Jews evacuated from the East were entering 
Ravensbrück in large numbers. ${ }^{9}$ More significantly, in terms of exchanging information in a common language, three groups of French political deportees who had formed part of the anomalous convoy sent from Compiègne to Auschwitz on 24 January 1943 arrived in Ravensbrück over the course of $1944,{ }^{10}$ while further contact between French deportees came after the evacuation of Auschwitz on 18 January 1945. Of the Jewish-authored corpus in question here, Alcan, Asseo, Davidovici, Grinspan, Heftler, Hollander-Lafon, Lagrange, Lévy-Osbert, Marmor, Picard, Tichauer, and Touboul took part in the 'death march' which led them from Auschwitz to Ravensbrück.

Observations relating to comparative conditions in the two camps can be split into various categories, beginning by those made by the members of the 'convoi de 24 janvier' arriving in Ravensbrück. Before considering these, it is important to note the potentially insidious nature of comparisons. Fears that one might be thought to be establishing a hierarchy of horror, or diminishing the reality of the suffering of some deportees undoubtedly prevented many from commenting on relative conditions, and indeed few risk the venture. Alizon (part of the convoy of 24 January 1943), tellingly, prefaces her comparative comments with a caveat - 'I'll probably make a lot of enemies among those who survived Ravensbrück' - before acknowledging that differences did, nonetheless, exist: 'although life was very hard in Ravensbrück, I never had to live through such awful hours as those I lived through in Birkenau' (1996: 320); 'As for the eight months I spent in Ravensbrück, however disagreeable they may have been, I have no memory of horror there. For the French women who only experienced that camp, it seemed terrible' (ibid.: 329). ${ }^{11}$

Comparisons drawn by Jewish deportees arriving in Ravensbrück are also rare, and on occasion point to similarity rather than difference in conditions, doubtless in part because by the time of their arrival in early 1945 Ravensbrück had its own gas chamber, and severe overcrowding was such that conditions had rapidly deteriorated. Touboul, for example, asserts: 'Ravensbrück is also a death-camp, a camp in which the "final solution" is implemented, a camp in which, like Auschwitz, thousands of women suffer and die' (1982: 153-4). For a few deportees, such as Marmor, who had worked as a translator in the SS offices at Auschwitz, a move to Ravensbrück and its sub-camps signified a drop in living standards (1990: 172). On the whole, however, Jewish deportees are reluctant to engage in comparisons, a fact which one deportee's remarks go some way towards explaining. Lagrange notes that in spite of the fact that so few French Jews survived, the French post-war public failed to distinguish between 
different categories of deportee. More significantly, as she points out, those Jews who returned were themselves reluctant to highlight the specificity of their situation: 'many Jews preferred not to be differentiated from the mass of survivors because they were very often afraid, unconsciously, of the distinction which had cost them the destruction of their families, of their lives' (1997: 191). ${ }^{12}$ Lagrange, like Alizon, nonetheless goes on to assert that conditions in Auschwitz were considerably worse than those in Ravensbrück. Her case is, however, something of an exception. While a few of those coming from Auschwitz make occasional comparisons - Lévy-Osbert, for instance, notes that her striking of a German prostitute in Ravensbrück would have resulted in certain death in Auschwitz (1992: 157-8) - bold statements such as Asseo's are rare indeed: 'You lot [in Ravensbrück] were "rich": you had planks to sleep on, bread from time to time, while we, haggard and skeletal, merely awaited the next awful decision, the next selection for the gas chamber' (1974: 109).

If deportees who had experienced conditions in both camps were reluctant to engage in comparisons, what of those non-Jewish deportees in Ravensbrück who learned second-hand of conditions in Auschwitz? Here too, comments are fairly limited. Both Pagniez and Roux register the arrival of non-French Jews from Auschwitz in the summer of 1944. Struggling with the language barrier, Pagniez comments primarily on the Hungarian Jews' physical state and the presence of their camp number tattooed on their arms (1947: 80). Roux, in contact with two German 'half-Jews', goes further, noting the presence of gas chambers and acknowledging the scale of the Jewish disaster: 'Father, mother, uncles, aunts, cousins, grandparents - they all perished in the immense auto-da-fé of an entire race' (1946: 48). ${ }^{13}$ The arrival of the French contingent prompts further comment, though it too is far from extensive. Le Guillerme, in an entry dated 10 March 1944, devotes one and half pages largely comprising unattributed dialogue to the 'terrifying things' conveyed by the French politicals, mentioning selections on arrival in Auschwitz, and again noting the tattooed numbers on the women's arms (1946: 137-8). Améry, recording the pitiful condition of Hélène Langevin, Yvette Mauvais, Mme Sampaix and Marie-Claude Vaillant-Couturier, ${ }^{14}$ acknowledges the relative harshness of the two regimes when she asks 'Are we in paradise here?' (1945: 95). Corblet de Fallerans is rather more forceful in her recognition of comparative conditions: 'I was stunned, deeply shocked: I'd never heard of selections and gas chambers. How could we complain having heard these accounts?' (1992: 128). When Brun learns that a group of deportees is about to be trans- 
ferred from Ravensbrück, and expresses the opinion that any move must be an improvement, she is quickly disabused by the newlyarrived Marie-Claude Vaillant-Couturier:

Open your eyes. Where I've just come from it's pure hell. Everything is planned down to the last detail for extermination on a large scale; there are several crematoriums burning night and day, you can't imagine, and if you get the chance to stay here, then stay, because you never know where you'll end up.

(1979: 197-8)

Finally, the arrival of French Jews in early 1945 prompts a further rare - comment: 'The sinister Auschwitz camp has been evacuated. Some colleagues, including Louise Alcan, have joined us ... Our camp seems pleasant compared to the one they've just left' (Lesèvre 1987: 122).

It has emerged that only a small proportion of deportees, Jewish or non-Jewish, and irrespective of when their accounts were written, were willing to engage in comparisons, whether because they saw such comparison as potentially damaging - to themselves or others - or, perhaps, in the case of political deportees in Ravensbrück, because their accounts were based, above all, on first-hand experience, and their knowledge of Auschwitz came to them at one remove. Certainly second-hand information could lead to misrepresentation. Simier, for example, describes the Auschwitz Sonderkommando burdened with the task of extracting gold teeth from the dead in the following terms:

These dentists were Jewish men and women who were themselves condemned to death and who volunteered for this macabre task for a period of six months after which their number was up. This guaranteed them another six months of life, with the possibility that the war would end and release them from their awful job.

(1992: 42, my emphasis)

Sadly, misrepresentation and stereotyping of this sort are compounded, in a surprisingly large number of cases, by more overt anti-Semitism.

\section{Anti-Semitism in French non-Jewish accounts}

Morrison claims that 'there is astonishingly little evidence of any antisemitic attitudes or behavior among the female prisoners' (2000: 72). If 'attitudes' and 'behavior' displayed in the camps were consistent 
with those described in the Ravensbrück accounts, his claim is a little wide of the mark. While anti-Semitic comments are by no means the norm, representations of Jews in a significant proportion of the political deportees' accounts range from essentialising stereotypes to more overt anti-Semitism.

First, we find 'the Jews' represented in terms of a race or people doomed to suffering, endowed with an age-old wisdom ('sagesse') and great intellectual qualities. Alizon, who, as we have seen, does acknowledge the extent of Jewish suffering in Auschwitz, nonetheless lapses into stereotyping when she suggests that while some prisoners found strength in political conviction, the Jews could rely only on their 'powerful and innate survival instinct' to see them through the ordeal. She adds: 'What sort of hope can you have when your people's history condemns you to death?' (1996: 209). Hautval, deported as an 'amie des juifs' ('friend of the Jews'), ${ }^{15}$ describes a three and a half yearold Jewish boy in the Auschwitz infirmary: 'A very sweet, intelligent kid, whose expression already reveals his race's age-old knowledge of suffering, like so many others that I've seen' (1991: 28). Du Fresnes, also a philosemite, expresses a similarly ahistoric view:

Read Ezechiel, Isaiah, Daniel, Revelation! The Jews failed in their spiritual mission which was to enlighten the world. They will be persecuted among nations, decimated, wandering the earth. But a very few will remain, and one day they will rediscover the sense of their true destiny. And then woe betide the nations which have persecuted Israel!

$(1947: 127)^{16}$

Dates of publication may vary but stereotyping often remains. Maurice's first publication, N.N. (1946) includes a chapter entitled 'Children in the land of wisdom' which singles out a young Jewish boy as the embodiment of this 'wisdom'. More than four decades later, her Les murs éclatés (1990), which, though far from anti-Semitic, abounds with Jewish stereotypes, includes the edifying tale of Olivier, a former Jewish deportee who accidentally phones Béatrice, a former Resistance deportee, in search of his aunt Sarah. In an attempt to atone for the French neglect of the Jews during the war years, Béatrice engages in an ever-closer epistolary relationship with Olivier and finally decides to meet him. The tale comes to a climax which plays out the cliché of the physically inept but intellectually gifted Jew. Olivier, severely handicapped, is confined to a wheelchair: 'she saw neither the shrunken body nor the withered legs. She saw only a face of transcendent intelli- 
gence gazing up at her, a face radiating goodness, and two eyes shining like stars' (1990: 112).

Negative stereotyping may emerge more subtly in metaphors, as typified by Lahaye's observation: 'The atmosphere in Block 27 is degrading. The seething mass of humanity, the ghetto filth, and this in a French block, are suffocating' (1954: 12, my emphasis). Paul refers to a similar use of the image:

Not everything that happened in Romainville was admirable. When I arrived I quickly found out that the room was divided into two: on the right, the Gaullists, the rare monarchists, the democrats and the republicans. On the left, in the other half of the room, were the Israelites, some democrat and republican, others Communist.

Invited to align herself with the 'right side', Paul balks in the face of the language employed: 'I was about to agree when one of the women came out with an unfortunate phrase: "Here, this is the way we are, but over there it's the ghetto!"' (ibid.: 74).

In other instances, representations take on a more overtly antiSemitic tone. One recurring motif is that of the 'filthy Jew', with its echoes of Nazi (and indeed Vichy) propaganda. When ToulouseLautrec records the arrival of a Jew in her cell in Montluc she chooses to focus on matters of personal hygiene (in an inappropriately flippant tone) rather than the subsequent removal of the woman to an uncertain fate:

There is also a very dirty Algerian Jew.

'Madame, you must wash tomorrow.'

The next day Madame Vrille observed:

'I watched her closely, but she didn't undress when she used the sink. She has not washed her feet.'

'Madame, you must wash your feet, and...'

$\cdots$

The next day she still hadn't got the message.

'Madame,' I said in as reproachful as tone as possible, 'this is no laughing matter, you must wash your feet.'

The next day there was a transport and the Algerian left... without having washed her feet. 
Blanc's assessment of Hungarian Jews in Ravensbrück is similarly selective - and more obviously hostile: 'Most of them are so dirty by nature that we have to watch them closely to make sure they wash' (1984: 286, my emphasis). Such anti-Semitic stances did not go unnoticed by the Jews arriving in the camp, as Lagrange recalls:

We are not welcome in Ravensbrück, far from it ... There is even some racism among certain prisoners who had actually been staunch anti-racists in a previous existence. I felt terrible when I heard a French woman from block 32 saying to one of her friends as she looked at our pitiful little gaggle: 'It's the yids. See how filthy they are, how they stink.'

If Jews were subject to a process of essentialisation and abstraction which consistently ignored material circumstances (they are represented as doomed as a race and dirty 'by nature'), they were also the target of a more specific form of anti-Semitism. As Silverman and Yuval-Davis point out: 'A powerful sense of national/cultural belonging has been the major means of racialisation (and hence the construction of processes of inclusion and exclusion) in France' (1999: 31). They continue: 'any signifier - biological, cultural, linguistic, religious, can be used to construct racialised boundaries' (ibid.: 39). By far the most prevalent manifestation of anti-Semitism on the part of the French political deportees takes the form of cultural racism based on language-difference. Sartre, adopting the voice of the anti-Semite, had also highlighted the importance of cultural - and linguistic factors in hostile constructions of the Jews:

It may well be that the Jew speaks a purer French than I do; it may be that his knowledge of syntax and grammar is greater than mine; it may even be that he is a writer. This is of no consequence. He has been speaking this language for only twenty years; I have been speaking it for a thousand.

(1946: 28)

If this is true of attitudes towards the francophone Jew, than it should perhaps come as no surprise that anti-Semitic representations in the accounts are especially hostile towards the Yiddish-speaking Jews. Whereas hostility directed at deportees of various nationalities was, as we saw in the previous chapter, the result of a nexus of factors, antiSemitic expressions focus most frequently on linguistic 'otherness'. 
Taken in isolation, such representations can seem relatively benign. Bouteille-Garagnon, for instance, describes an elderly Jewish woman bathing her black eye 'while moaning in some garbled tongue' (1946: 18). However, representations which focus on language difference, and indeed often confer sub-linguistic and sub-human attributes upon the Jewish deportees, are far from uncommon.

Lahaye's affirmation of positive values in the camps - 'bereft of love, our souls took refuge in charity. Charity became the locus of those impulses usually focused on passion, maternal love, and all forms of altruism' (1983: 118) - is compromised by the statement that: 'Now we know that central European Jews, when herded together, smell like wild animals and have whining voices' (ibid.: 146). Gorce's description of a Jewish woman combines recurring motifs of filth, bestiality and lamentation:

There's a sickly Jewish woman snivelling next to her who's after my place.

'Leave me alone, you filthy pig.'

'Hi... hi... hi...'

I know what she's trying to do - make everyone feel sorry for her so they turn on me and she can take my place.

(1995: 125)

When Gorce later refers to a Jewish mother forcibly separated from her children, a similar combination reappears, this time with an additional allusion to Jewish passivity: 'I can still remember another Jewish woman, with a bit more fire in her, less resigned that her co-religionists, clutching her child and screaming ... She left belling like a doe whose fawn has been taken away' (ibid.: 163).

References to the sub-human and the sub-linguistic often combine with allusions to lamentation: the 'Wailing Wall' makes frequent appearances. ${ }^{17}$ Referring to the tears of a newcomer in Montluc, Toulouse-Lautrec acknowledges that such distress is normal. Upon discovery that the latest arrival is a Jew, she adds: 'What a nose! What a nose! We're not anti-Semitic, but really, Lysica cries too much' (1967: 87). De Loulay, commenting on the distress caused by the separation of children from their mothers in Ravensbrück observes that 'the Jewish women wail loudly enough to get the attention of everyone in the sleeping-quarters' (1945: 93). Blanc and Améry echo the terminology: 


\section{Deportee identities III: Jewish identities}

Now that they are prisoners in Ravensbrück, they deafen us with their endless lamentations, croaked out in their usual grating voices. Once you've heard one you can pick out her like from thousands. The whining, the tears, the never-ending 'Proché Pany' of the Polaks are nothing compared to this unremitting 'Wailing Wall'.

(Blanc 1984: 285)

The camp is filling up too - as if it weren't already full enough with Israelites of all nationalities; it's turning into a wailing wall. Afraid, constantly whining, they rub shoulders with the authorities, indifferent to rebuffals, oblivious to the fact that they are creating their own misfortune.

(Améry 1945: 115)

What are we to make of these displays of anti-Semitism? It should be noted that they cluster especially (though not exclusively) around the depiction of the mass arrival of Jews into Ravensbrück from late summer of 1944 onwards. In this, a familiar pattern is being played out. At the close of the nineteenth century an influx of Ostjuden into Western Europe gave rise to increased anti-Semitism, just as the mass immigration of foreign Jews - referred to in the anti-Semitic rhetoric of the times precisely as 'invasions' - increased hostility towards the Jews in the France of the mid- to late 1930 s. ${ }^{18}$ Ravensbrück, it could be suggested, became yet another 'territory' perceived by some as subject to unwelcome 'invasions' coming, once again, from the East.

One would surely have hoped that the experience of facing the very real physical violence and SS-imposed prisoner categorisation that were part and parcel of concentration camp life would militate against the psychological violence of essentialisation and racialisation carried out by deportees themselves. One might also assume - wrongly - that accounts published in the 1980s and 1990s would see the expurgation of anti-Semitic material.

\section{Assumed identities: Jewish-authored texts}

The binary commonly invoked when discussing the Jews of France during this period distinguishes between 'Israelites' and 'Jews'. Distinct characteristics are ascribed to each term: the 'Israelite' is typically regarded as an assimilated French national, francophone, middle-class, with little if any notion of belonging to a Jewish

'people'; the 'Jew', by contrast, is depicted as 'foreign' (usually of 
central or eastern European origins), practising, steeped in Jewish culture, Yiddish-speaking, and usually a member of the working or artisan class. The discussion below has been divided into two sections, examining first a range of typical accounts authored by women belonging to assimilated French families, before turning to those written by immigrants or the children of immigrants who came to France in the early decades of the twentieth century. Although these two groups of texts do display different characteristics, the binary constructs ('French'/'foreign'; 'Israelite'/'Jew') and the individual terms of each binary will be seen to be somewhat reductive.

\section{French born and bred: 'Israélites'?}

It can be estimated that approximately half of the Jewish-authored corpus was written by Jews belonging to long-established French families. (The status of some writers who appear to fall into this category cannot be ascertained with any certainty as not all comment on their background.) The following group of writers have one thing in common: their identity as French citizens predominates over their Jewish identity, though even here important differences in the negotiation of French/Jewish identities emerge.

If we consider self-representations in terms of a spectrum, one end is occupied by those writers whose Jewish identity is minimised or even elided. Maous's account, for instance, reveals a curious clash of discourses between text and paratext. The preface is written by Pierre Vidal-Naquet, who recognises that both he and Maous belong to the same 'French Jewish bourgeoisie', and lays great emphasis in his commentary on the what he terms 'Hitler's genocide' (1996: 13) and the dangers of negationism. The main body of the account, however, makes minimal reference to its author's status as a Jew. Above all Maous emphasises her Frenchness, noting the importance of her friendships with other French deportees, referring to her group's 'recently-acquired aversion to everything that was not French', their 'fierce indifference towards everything that was not us' (ibid.: 90), and pointing out that her temporary move to a barracks occupied only by Hungarian and Polish Jews nearly resulted in the loss of her sanity (ibid.: 99).

The reader of Maous's account has little impression of the author's sense of belonging to a Jewish community, a pattern which is repeated in texts authored by Birnbaum and Alcan. The hierarchical positioning of noun and epithet in Birnbaum's Une Française juive est revenue announces its author's priorities from the outset. Only rarely does 


\section{Deportee identities III: Jewish identities}

Birnbaum mention Jews. When she does, it is either to highlight inequalities and conflicts in the camp regime (although the Poles are 'Jews like us', they are consistently hostile towards the French (1946: 65); only Jews are singled out for selections, ibid.: 74) or, interestingly, in a (presumably ironic) self-deprecating assumption of Nazi terminology. Birnbaum thus tells us that the labour detail in which she worked sorting potatoes is obliged to set aside 'the small ones and the mouldy ones for the pigs, in other words for the Jews' (ibid.: 83).

Alcan (who points out that her parents and grandparents were French when she is singled out for an 'ethnological survey' in Auschwitz) was arrested as a resistant and imprisoned in La Baumette, Marseilles, alongside other political prisoners. Doubt over her identity prevailed for some time (and remains in the mind of the reader): as she puts it 'I may not have been able to prove that I'm not a Jew, but the Gestapo has apparently not yet decided that I am' (1947: 14). Ambiguity is only removed when she finally states: 'Change of programme. The Gestapo has decided that I'm a Jew. ... I'm now waiting to leave for Drancy' (ibid.: 16). As in Maous's case, the emphasis in Sans armes ni bagages is very much on French identity: communal singing of the Marseillaise on 11th November; a Christmas scene involving the construction of a window framed by red curtains and back-lit by a candle opening onto a representation of France (ibid.: 77). The text is marked by pronominal ambiguity characterised by an apparent reluctance on Alcan's part to refer to Jews in the first-person plural: 'It is said that the earth is soaked with the blood and tears of the Jews. It is said that soap is made from the fat of those who are gassed then burned. Who are we washing ourselves with...?' (ibid.: 30).

Alcan's first account was written in 1947. Her subsequent publication, Le Temps écartelé (1980), reveals the manner in which Jewish consciousness emerged in the later decades of the century (as discussed above in Chapter 1). Although a sense of the author's identification as a Jew while in the camps is still far from extensive, references to the author's time in the camps are now overlaid with an extensive contrapuntal commentary focusing on the Jewish experience of deportation and comprising a range of facts and anecdotes relating to both the war years (the Vichy regime's treatment of the Jews) and subsequent representations of the camps (negationism, lack of knowledge on the part of the general public). Alcan's texts reveal a curious but not uncommon phenomenon: that of the French-identified Jew who lacks any personal experience of 'membership' of a Jewish community before the war, yet nonetheless feels the need, or obligation, to register some sort of rela- 
tionship to that community. Where Alcan's ambiguous representation of her own identity - as a Jew who, perhaps, believes that she ought to feel more of a Jew - emerges in the differences between her two accounts, Touboul's similarly ambiguous self-representation is revealed in a single text. Like Alcan, when it comes to representing her time in the camps, Touboul's emphasis is very much on her identity as French (the common topos of the singing of the Marseillaise on leaving Drancy; her French fellow-deportees' giving her a picture of France for her birthday), with little sense of a Jewish identity. However, as with Alcan's second account, Touboul punctuates her text with facts and statistics relating to the deportation of the Jews, producing a curiously two-levelled account in which the author is represented as both not Jewish-identified - at the time of her deportation - and somewhat more Jewish-identified - at the time of writing the account. As with Alcan's later publication, the reader of Touboul's account forms the uncanny (and grammatically unfeasible) impression that its author's identity lies between a Jewish 'we' (she acknowledges and accepts the imposed definition) and a 'they' (she appears to have little if any interiorised sense of Jewish identity).

In the case of the accounts considered so far the issue of a problematic negotiation of Jewish identity is inferred by the reader rather than raised explicitly. The accounts of Crémieux and Fabius, both of whom were deported to Ravensbrück as resistants in spite of their being Jews, reveal more complex identity fault-lines, though of different sorts, and for different reasons in each case. Crémieux's account is almost entirely devoid of references to her Jewish status. Only when recounting her arrival in Ravensbrück alongside a group of fellow-resistants does she mention - significantly, in a footnote - that they had been separated from one of their number who had been identified as a Jew and taken elsewhere. Crémieux goes on: 'Tall, blond with blue eyes, and tanned by the mountain air, although I was a Jew I was marked out by the "expert in identifying Jews" who examined us as a "typical aryan from the Normandy region"!' (1999: 37, footnote 1). Crémieux's identity as a Jew subsequently arises explicitly as an issue only when and because Sullivan, her co-writer and interlocutor, questions her about (what he perceives as) a potential betrayal and denial of her roots (ibid.: 126). Crémieux's response to Sullivan's questions is tellingly tangential. She entered the Resistance, she replies, because her family originated in Alsace and had moved to Normandy in 1870 in order to avoid 'becoming German' (ibid.: 127). Having lost relatives in World War I and again in 1940, patriotism was all-important: 'my resistance activities went back a long way; they were part of my family history' (ibid.: 
127). Symptomatically wholly eclipsed in Crémieux's reply, Jewish identity appears to the author to be incompatible with, or quite simply irrelevant to, French citizenship and nationalism.

Although there are similarities between Fabius's account and Crémieux's, a comparison of the two texts offers a crucial reminder that each term of the 'Israelite'/'Jew' binary must be opened up to differences. Like Crémieux, Fabius denies her Jewish identity when arrested. Also like Crémieux, she identifies strongly as French: 'We come from such old established French stock that nothing bad can happen to us' (1986: 62). Stressing her family's assimilation, she distances herself from the stereotypic stateless Jew: 'we felt very far removed from the sorry figure of the Wandering Jew' (ibid.: 25). Fabius uses the same phrase as Crémieux - 'family history' - when she points out that it was precisely her family's long-standing status as French citizens which precluded any anxieties about her identity as a Jew: 'I felt so French, with such a family history behind me, that the "Jewish problem" didn't even cross my mind' (ibid.: 60). She too stresses the importance of nationalist feeling: 'Patriotism was deeply embedded in my family' (ibid.: 67).

There are, however, significant differences between the two accounts and in the authors' self-representations. Whereas Crémieux's 'denial' of her Jewish status and her potential reactions to this denial are elided from the text, Fabius chooses to represent her arrest and denial, pointing out that the latter was a deliberate act of self-preservation: 'If I'd hesitated for even a fraction of a second I would no longer be alive' (ibid.: 97). Fabius, like several of the authors discussed thus far, on occasion uses the third person to refer to the Jews. She records the following exchange which took place at the time of her arrest, when she was asked why she associated with Jews (in whose company she had been seeking to pass the demarcation line illegally): "But for us they're just people like everyone else."/“For you, the Jews are people like everyone else?"/"Yes, for we French, the Jews are people like everyone else"' (ibid.: 98). Unlike the authors discussed so far, Fabius's pronominal splitting ('we'/'the Jews') is ambiguous. It could be interpreted as a deliberate strategy (reinforcing her interrogator's belief that she is not a Jew) rather than the articulation of a lack of any sense of affiliation with a Jewish community.

Indeed, Fabius's account serves to remind us that assimilation does not necessarily equate to a lack of awareness of, or participation in, Jewish culture. Where Crémieux clearly has no such sense of Jewish identity, Fabius tells us that she comes from a non-practising Jewish family, but also points out that she married in a synagogue (ibid.: 35 ) 
and wishes to be buried in a Jewish cemetery (ibid.: 249). As well as emphasising her French roots, she acknowledges her centuries-old descent from Spanish and Portuguese Jews (ibid.: 24). In spite of outward denials, a sense of belonging to a wider community, however vaguely defined, is articulated: 'Being a Jew is a state of mind; it's something very personal' (ibid.: 67). Although both Crémieux and Fabius could be described as 'Israelites' - both stress assimilation and French identity, and Fabius reveals a typical separation of the visible and the invisible, the public (French) and the private (Jew $)^{19}-$ the word 'Israelite' does not adequately accommodate what are clearly very different perceptions and representations of Jewish identity (or lack of it).

Fabius's account introduces one further important factor - class into the construction of identity, and one which again reveals the limitations of the Israelite/ Jew binary. Many families such as hers which had established themselves in the south-west of France centuries before, and which had secured privileged social status, were, she suggests, aware of a veritable 'social and cultural chasm' separating them from their French co-religionists from other regions and with less ennobled backgrounds (ibid.: 24). ${ }^{20}$ French assimilated Israelites, in other words, should not only (in some cases) be distinguished from the supposedly lower class foreign 'Jews', but from each other. In fact class-identity as related to the 'Jews' is also more complex than the binary suggests. A brief digression to accounts authored by immigrant Jews reveals that not all were working class or artisans (though here again we should note the bias in the sample of texts). Marmor, for instance, clearly came from a relatively privileged background complete with piano lessons and a nanny. Holstein's father was a dentist. As Tichauer's account reminds us, immigrant Jews were often obliged to give up or change their professions. Tichauer's father was a lawyer in Germany. Once in France he found himself obliged to turn his hand first to the manufacture of bakelite saucers (a failure - as Tichaeur states, contrary to popular perception, not all Jews are good businessmen, 1988: 32), then to take evening classes as a machinefitter because of a 'politico-economic regulation which aimed to reduce the number of immigrant intellectuals by transforming them into skilled workers' (ibid.: 32-3). Some immigrants were indeed poor and poorly educated - Grinspan's father left school early, training as a tailor from the age of 14; Schapira's parents started up a small secondhand shop in Paris - but their children (authors of the accounts in many cases) received good educations and were destined for whitecollar professions. 


\section{Deportee identities III: Jewish identities}

Fabius also points out that many assimilated Jewish families such as hers were in all probability quite unaware of the very existence of 'those from eastern Europe' (1986: 24), thereby introducing another common factor in the construction of Jewish identity: the oppositional relationship between French Jews and those of eastern or central European origins. The conflict that existed between these two groups in France is well documented, but their relationship in the context of deportation has received little critical attention. Wieviorka suggests that deportees did not make such distinctions: 'When survivors describe Drancy or Auschwitz in their accounts, this distinction French Jew-foreign Jew disappears. Maybe it seems trivial in the light of the scale of the Catastrophe' (1992: 287). This is not quite the case. Many writers do refer to strong antipathies between the two groups, and often reveal that in a 'neutral' context, or indeed one in which the assimilated Jew was in the minority, antagonism was mutual. Picard, who describes herself as French and 'of Jewish denomination', indicates that she faced hostile mockery on the part of Russian and Polish Jews in Drancy because of her inability to speak Yiddish. In this particular case Picard and her co-detainee Huguette did little to ameliorate relations. The latter, who spoke a little Yiddish, came to Picard's rescue with the ill-judged rejoinder: 'Be quiet .... You don't know WHO she is; you don't know WHO you are talking to. Her mother owns THE LEADING clothes shop IN FRANCE, IN PARIS' (1995: 95-6). The response to this nationalistic outburst remains unrecorded. Later in the account Picard reveals her own anti-Semitism when she describes her aunt (bilingual in French and Yiddish) as 'sly as a fox, like many of her kind who emigrated from central or eastern Europe at the end of the last century or the beginning of this one' (ibid.: 103).

Other deportees facing similar antagonism respond in more tempered and less nationalistic manner. When Jewish members of the orchestra in Auschwitz were ordered to step forward, Fénelon, who describes herself as a 'half-Jew' with a Jewish father and French Catholic mother, found herself in a difficult position. Fénelon claims that she positioned herself mid-way between the groups of Jews and non-Jews and removed half of her Star of David, leaving a yellow triangle with the ' $F$ ' for France. Her failure or inability to identity as

Jew or non-Jew was met with derision and hostility from both Jewish and non-Jewish Poles: 'You bitches, being so shamed to be Jews! But will be Jews always, you never aryans, you afraid, so you, deny your parents. Judases!' (1976: 114; the words are spoken by a non-Jewish deportee; we are told that the Jewish contingent concurred). Fénelon's retrospective response is a pragmatic one akin to that of Fabius. She 
asks: 'Are we not entitled to distance ourselves as much as possible from the "chosen race" faced with the other, the master race? It's afterwards if there is an afterwards - that we'll have to fight, have to assert our Jewish identity' (ibid.: 116). Faced with continuing hatred, she tells us that she nonetheless opted to restore her Star of David (ibid.: 157).

A final example introduces further differences in the assumption and construction of Jewish identity among primarily French-identified Jews. At the outbreak of war the young Christophe, unlike Fabius, could not even have been described as an 'invisible' (private) Jew; she quite simply had no idea what the word meant, and records plaguing her mother with questions: 'But mummy, what does being a Jew mean?' (1996: 19). Unlike the other authors considered so far, Christophe's identity was to undergo a marked change. Although she was initially forced uncomprehendingly to accept the imposed label 'Jew', exposure to Jewish-identified deportees in Drancy gave rise to a degree of self-questioning and an admiration for Jewish faith and culture: 'The Bauer family, who were very devout, introduced me to the Jewish religion, and I admired it, though I wasn't persuaded, because I'm not the religious type' (ibid.: 55). Her mother had a similar experience in Pithiviers, where she observed orthodox Jews at prayer for the first time:

Once I'd got dressed again after washing I noticed something behind the screened-off washing area which I'd never seen before. Five or six practising Israelites were performing their devotions. Wearing skullcaps, their shoulders covered with prayer shawls, with little leather phylacteries on their foreheads, they were chanting in Hebrew with such conviction, and so oblivious to the risk they were taking, that I was overwhelmed.

For her mother's birthday the young Christophe chose to fashion rudimentary 'Tablets of the Law' from the clay soil. She was also instructed for the first time in the Jewish faith by a young rabbi (1996: 56). Strikingly, it is only when faced with a potential conflict between national and Jewish identities that Christophe encounters difficulties relating to the perception and representation of her own identity. A group of Polish Jews in Bergen-Belsen are adamant in their claims:

'You Jew?'

'Yes, I'm a Jew, I'm here aren't I?' 
'So speak Yiddish.'

'Of course not. Where would I have learned it?'

'So you not Jew.'

(ibid.: 78)

From this point on, Christophe is faced with an apparent choice between national and Jewish identities. In the face of the Polish Jews' denial of her status as a Jew, and the language which separates them, she first decries the notion of a Jewish race, emphasising instead the strength of national identity and affinity: 'When Hitler spoke about the "Jewish race" he was way, way off the mark. We French recognise each other at a glance' (ibid.: 79). For Christophe, the Poles, whom she describes as 'stateless' and 'just Jewish' (ibid.: 79), are to be pitied for their lack of nationalist belonging. Such is her inability to envisage the co-existence of national and Jewish identities that her final pronouncements about her own identity topple into the stereotypical. In spite of her insistence that she is not, and will never be, a believer, she first pronounces that 'I'm not a French Jew but a French citizen of Jewish faith' (ibid.: 104). This typical assimilationist model is then succeeded in the closing words of the account by an essentialising and reifying articulation of Jewish community: 'In the end maybe that's what being a Jew is: belonging to a community of suffering and refusing to hate' (ibid.: 161).

\section{Immigrant families: 'Juives'?}

The first group of accounts reveals that assimilated French-identified Jews assume their (a) Jewish identity to varying degrees, and that the term 'Israelite' and the traits commonly associated with it mask important differences in the construction of identity. The second group of accounts comprises texts authored by immigrants who came to France and obtained French nationality prior to their deportation and, more commonly, the children of immigrants usually born in France and declared French by their parents. Once again aspects of a representative sample of texts will be discussed, with a view to unpicking the terms of the 'Israelite'/'Jew' binary.

Unlike the majority of primarily French-identified authors, immigrant Jews often devote considerable space in the early pages of their accounts to their family origins. Those who came to France as adults and obtained naturalisation typically express uncertainty about their national identity. Marmor, for instance, informs us that she was brought up on the Austro-Hungarian border, and that the family left 
for Vienna in 1914. Her parents subsequently returned to their home, which had been handed over to Poland according to the terms of the Treaty of Versailles. Marmor never saw them again. She herself married and moved to Paris (no precise dates are given) where she eventually obtained French citizenship. Each introduction of a new geographical location in the account is headed by the question: 'Where is my native country?' (1990: 29, 45), and Marmor draws a strong distinction between her own uncertain national identity and that of her son, born in France: 'I watched over the childhood of my little French boy, born in this country and declared French at birth ... You will have a native land. You will have a mother tongue' (ibid.: 52). Asseo states that she was born a Turk and brought up near the Aegean in a town then called Dédéagatch and subsequently renamed Alexandropolis. Stressing the ever-changing frontiers resulting from battles fought among Greeks, Bulgarians and Turks, she asks: 'who could tell me what I was?' (1974: 25). Similar complexity arises with the case of Novac. Asked by a French woman in Auschwitz 'So what are you then?', she replies: 'My grandfather was born in Austro-Hungary, my father in Hungary, I was born in Romania, all of us in the same town in the same street' (1996: 219). The French woman's grasp of her own identity is somewhat more straightforward: 'She says she's “a Parisian”, end of story' (ibid.: 219).

The above deportees' conceptualisation of their own national identity cannot be accommodated by the 'French'/'foreign' binary. They were indeed 'French' when deported (with the exception of Novac), but all insist on preserving and representing their often complex family history. A similar pattern emerges in the accounts written by the children of immigrants who almost without exception also devote space to their family background. Born in France in 1926 and declared French, Schapira informs us that her Polish parents came to France in 1924 to flee virulent anti-Semitism. Her father's attempts to secure his own and his wife's naturalisation (he signed up for the army in 1940) failed repeatedly and both were deported as 'stateless'. Holstein (also a French citizen by parental declaration) takes us back a generation, informing us that her maternal grandparents fled the pogroms of Lithuania in the 1920s, and that she has both English and French roots via her paternal grandparents. In nearly all cases the oral communication of family history forms an important part in the construction of these writers' identities. Having informed us that she was a naturalised French citizen of German parents (also naturalised), Tichauer, for instance, traces one side of her family back to the pogroms of Poland and Russia and the other to the Spanish Inquisition (1988: 31). She adds: 'I accepted the oral tradition of my family according to which I 
was descended from Levi, son of Jacob and Lea, on my Ashkenazi father's side, and from King David on my Sephardic mother's side' (ibid.: 31).

Not only were families split along national lines - French citizenship was in many cases granted to children but not to their parents; parents and children were subsequently frequently deported separately - naturalisation itself was by no means definitive. Tichaeur's family fled Germany in 1933 and was granted naturalisation in 1937. As Tichauer states: 'So we were French when I began studying medicine' (ibid.: 37). But for Tichauer and many like her, this new-found French identity was to be short-lived. The state could and did alter official identities with often fatal consequences, a 'French Jew' becoming 'stateless' overnight. A law passed on 22 July 1940 saw the setting up of a commission charged with the review of awards of French citizenship granted since 1927. The Tichauer family had its naturalisation revoked under this legislation, and was seized in the Rafle du Vel d'Hiv on 16 July 1942. During the course of the next three years 7,055 French Jews were to have their French citizenship revoked.

As we have seen, in the case of immigrants and their children the articulation of national identity is more complex than a simple 'French'/'foreign' binary (mapped onto the 'Israelite'/'Jew' binary) allows. The same can be said of the other traits typically associated with these binary terms: language, religious observance and involvement in Jewish culture and community. Just as some Jewish immigrants refer to having 'multiple' national identities or none, so they often represent themselves as multi-lingual or as having lost track of their first language. ${ }^{21}$ Marmor states: 'I'm a product of a Europe in the throes of destruction and resurrection, which means I have no mother tongue' (1990: 18-19). Tichauer reminds us that she had to learn the language of her adopted country and try to rid herself of her accent (1988: 33). ${ }^{22}$ Novac, who chose to (re)write her account in French, states with typical wit: 'I dream in three languages with an accent in each one. My passport has the word "Jew" in it written in Hungarian even though I don't understand a single word of "Jew" (1996: 219). Louria records a fellow-deportee in Auschwitz attempting to communicate with her 'in a language which was unfamiliar to me but which I thought might be Yiddish' (1979: 56); Tichauer points out that before moving to France the family spoke 'Hochdeutsch' rather than Yiddish (1988: 29). For some children born in France, however, Yiddish was their first language: Grinspan informs us that she spoke it in the home until the age of 4, whereupon she learned French prior to going to school for the first time (Grinspan and Poirot- 
Delpech 2002: 23). ${ }^{23}$ As with many immigrant families, her father followed his child's lead: 'Later my father would have French lessons and ask for my advice ... He was proud if he could catch me out with conjugations' (ibid.: 21). Holstein, by way of contrast, assumed that the Yiddish she heard spoken by Polish Jews in Drancy was German, and was astounded to discover that her father could both understand and speak it (1995: 36). Strikingly, Holstein's representation of her ignorance of Yiddish and indeed of eastern European Jews is followed by an admission of guilt. Although at the time she felt no kinship with the Poles and other Yiddish-speakers - 'in fact, I felt much closer to non-Jewish French people than to foreign or stateless Jews' - her stance was to change: 'I'm a little ashamed now of the way I used to distinguish between foreign and French Jews' (ibid.: 36). Unsurprisingly, and in contrast to French-identified assimilated Jews, the children of immigrants very rarely express hostility towards, or construct their own identities in opposition to, central or eastern European Jews.

Turning to the question of religious observance and cultural knowledge and practice, we see once again that immigrant families, and especially the children of such families, do not fit into the tidy oppositional categories 'Jew'/'Israelite', but rather that a range of differences must be recognised. Only Davidovici, Schapira and Asseo state or imply that they are observant Jews, but with one exception - that of Davidovici - little is made of this in their accounts. Born in Hungary of Hungarian parents and the daughter of a rabbi, Davidovici reiterates on several occasions that faith alone allowed her to survive, punctuates her account with references to Jewish teachings, and observes the prohibition on writing the name of God (she uses the form 'D.ieu' throughout). Kept appraised of important dates in the Jewish calendar via information provided by deportees in the men's camp (1998: 33-4), Davidovici sought initially to observe the Sabbath, swapping bread for candles. We are reminded, however, that religious observance in the camps could prove fatal. Having avoided eating soup for a week (it was not Kosher), she decided that remaining alive was the greater duty, adding that a young Hungarian who fasted twice weekly died in a matter of weeks (ibid.: 28). Schapira and other observant Jews adopted a more pragmatic approach to Kosher food and fasting from the outset: 'I and many like me decided that we were fasting quite enough as it was every day, so we decided to eat' (1994: 80).

Contrary to the terms of the binary, religious observance among the immigrant Jews and their children is almost as rare as it is among the French-identified group discussed above. What is apparent is a greater 


\section{Deportee identities III: Jewish identities}

knowledge of and participation in Jewish culture and tradition. Although not practising Jews themselves, a significant proportion of those born in France of immigrant parents mention that their grandparents were observant, and several point out that their parents attended synagogue, if only infrequently. Cultural ties and tradition remain strong in many cases. Tichauer recalls seeing her father 'dressed like a believer, carrying the Torah and chanting in Hebrew', informs us that her mother could read Hebrew, and remembers the apple studded with cloves given to her by her mother to help her overcome her hunger while fasting for Yom Kippour (1988: 25). Although she states categorically that her family were not believers, religion, she suggests was 'something which bound immigrants together in their misery' (ibid.: 25). Louria, in similar manner, stresses the importance of a Jewish identity forged in tradition when she records the tale of fellowdeportee Béatrice whose father, we learn, was not a practising Jew but observed Yom Kippour 'to honour the memory of her parents' (1979: 114). Holstein points out that her parents rarely spoke of religion to their children, adding that her brother nonetheless had his bar mitzvah (1995: 19). Grinspan, finally, observes that religion was never a subject in her family but that an immersion in Yiddish culture was an important part of her identity: 'We immigrants saw a great deal of each other. We were all Ashkenazi and spoke Yiddish' (Grinspan and Porrot-Delpech 2002: 23); 'My parents took me with them. We went to the Yiddish theatre in Lancry Street. Yiddish films were shown at the Belleville Boulevard' (ibid.: 25-6).

Immigrant Jews and their children tend to display stronger ties to Jewish culture, community and tradition, and their national identity is represented in such a manner as to embrace their familial origins (in eastern or central Europe), but where does this leave their relationship to France? Wieviorka suggests that for both long-assimilated Jewish families and the children of immigrants loyalty to France was unshakeable: 'they cannot call into question that which lies at the very heart of their identity' (1992: 282-3); 'for the vast majority of Jews of whatever origin who wish to remain in France, Vichy is not France. France remains the country of their emancipation' (ibid.: 349). The accounts bear this out, but only up to a point. Certainly representations of French solidarity (singing of the Marseillaise, the formation of exclusively French groups in the camps, the celebration of 11 November and 14 July) are present in many accounts authored by immigrant Jews or their children. However, while it is also the case that most immigrant Jews and their children reserve their condemnations for Vichy, Wieviorka's statements are too unequivocal: many accounts 
reveal somewhat more ambivalent displays of national loyalty to France. Grinspan chooses to highlight those French citizens who helped and sheltered the Jews, and maintains a clear distinction between France and Vichy: 'I nonetheless remain convinced that being betrayed by Vichy does not mean being betrayed by France.' She does, however, also point out that it was precisely the Jews' profound (and evidently misguided) faith in France's hospitality which was their undoing (Grinspan and Poirot-Delpech 2002: 219-20). Tichauer's response to the revoking of her French citizenship is also tinged with ambivalence. Like Grinspan, her condemnation is aimed primarily at Vichy: 'I will never forget the responsibility of the fascist Vichy government' (1988: 165). But Tichauer also points out that she initially refused an invitation to join a French 'collective' in Auschwitz: 'I'm still traumatised by Pétain's withdrawal of my naturalisation and don't really know where I stand in relation to France' (ibid.: 109). Schapira may tell us that she joined in the chorus of the Marseillaise on 11 November in Bergen-Belsen, but she also states unequivocally of the arrest of her family: 'all this was a consequence of the will and enthusiasm of the French police' (1994: 27). She continues:

There were only French policemen in that police station; not a single German. I want to stress this to underline the fact that the French police had completely sold out to the occupying forces; they behaved like the Germans, in fact sometimes they were even a step ahead of them.

(ibid.: 27-8)

Davidovici, too, points out that she and many of her friends were denounced by French citizens (1998: 11). However positively relations to France are represented, a minor key of hesitation and doubt thus inflects many of these accounts.

\section{Republicanism and (imagined) communities}

Such ambivalent affirmations of faith in France reflect the equally ambiguous status of the French wartime nation and indeed of France's republican tradition. Many accounts authored by immigrant Jews or their children stress the fact that it was precisely France's republican past which had motivated their or their parents' choice of destination as they fled anti-Semitic persecution in central and eastern Europe. As Grinspan (among very many others) puts it: 
France had an incredible reputation in central Europe. Although they [her parents] did not know anyone there, they knew that France was the land of Revolution, the land of freedom, of tolerance, the land which had emancipated the Jews.

(Grinspan and Poirot-Delpech 2002: 22-3)

In a speech delivered on 16 July 1995 on the occasion of the commemoration of the 'rafle du Vel d'Hiv' - a speech in which a French president publically acknowledged the responsibility of the French state for the first time ${ }^{24}$ - Jacques Chirac described France in terms which bring out something of the dilemma faced by the Jews of France:

France, land of the Enlightenment and the Rights of Man, land of hospitality and asylum, on that day France accomplished something irreparable. Breaking its word it delivered those whom it was meant to protect into the hands of their executioners.

(Conan and Rousso 1996: 446)

To which France were the Jews to pledge their loyalty? Can national identity be anything but problematic when the nation in question is itself divided? Although this is not the place for a discussion of the Vichy regime as a suspension or extension of the French republican tradition, it should be noted that the latter is itself somewhat ambiguous in the eyes of many critics. Although republicanism may well seem to represent the very antithesis of racism, its universalist, assimilationist ethos, premised on the rejection of difference, has been seen by some as the root cause of exclusion:

In official discourse the only way of categorising those residing in French territory is through nationality: you are either a French national (and therefore citizen) or a foreigner. Consequently, France accords full rights only to free and equal citizens before the law, and not to communities.

(Brah et al. 1999: 6-7)

Judith Friedlander pushes the point a little further:

It would be irresponsible, not to say outrageous, to link the persecution of Jews under Vichy to the French democratic tradition. Without conflating the two, we might still suggest that collaborationists in France found ways to distort the democrats' aversion to 
difference. From the very beginning of the French Republic, those favouring the emancipation of the Jews envisioned creating an ethnically homogeneous nation.

$(1995: 63)^{25}$

In short, the republican tradition and its 'aversion to difference' exclude communities, and herein lies the cause of one of the difficulties faced by the Jews of France when it came to conceptualising their identity as both French citizens and Jews.

Tensions between national and Jewish identities have emerged throughout this chapter. Whether practised by the state or by individuals, anti-Semitism was seen above to be premised on the subsuming of national identity by racial or racialised constructs. One need only consider the race-based 'Statuts des Juifs', or representations in the accounts of a Jewish race variously represented as endowed with wisdom, dirty, passive and doomed to persecution. History in these cases is displaced by the ahistorical, national belonging gives way to race. When it comes to representing their own identity, the assimilated French Jews often reveal themselves to be unable to reconcile the two identity constructs 'French citizen' and 'Jew'. In the case of those Jews designated as such by others but with no sense of belonging to a Jewish community, Jewish identity is simply elided in favour of French nationality. In other cases identity is constructed in hierarchical terms: (public, visible) citizenship prevails over (private, invisible) Jewishness: the typical republican model of the 'French citizen of Jewish confession' or 'French Israelite' (the latter term being, as we have seen, too reductive to embrace the reality of a range of cultural and religious practices). Identity may, finally, be constructed in opposition to the 'foreign Jew' (two terms which, again as we have seen, are somewhat reductive). In some cases, the problematic nature of Jewish identity is revealed via an uneasy pronominal hesitation: 'we' or/and 'they'?

Immigrant Jews and their children faced additional difficulties. In his study of nationalism, conceptualised in terms of an imagined community', Benedict Anderson points out that patriotism is often expressed in terms of kinship (the motherland or fatherland), this 'vocabulary of kinship' highlighting the fact that national identity is perceived as 'given' or 'natural': 'nation-ness is assimilated to skincolour, gender, parentage and birth-era - all those things one cannot help' (Anderson 1991: 143). Anderson further suggests that 'from the start the nation was conceived in language, not in blood' and that individuals can be "invited into" the imagined community'. As he points 
out, 'even the most insular nations accept the principle of naturalization (wonderful word!)' (ibid.: 145). Not only was the naturalised immigrant Jews' sense of French national identity undermined by their experiences at the hands of the Vichy regime (and in some cases at the hands of anti-Semitic French deportees in the camps); for the older immigrants France was their country of adoption, not birth. Far from being 'natural', it was a nation deliberately chosen, ironically, as a place of refuge, and a country whose language had to be learned, taking over, at least in public life, from the mother-tongue. And where France was the country of birth (in the case of the children of immigrant families), a sense of national belonging was tempered by a certain degree of loyalty to, or at least acknowledgement of, the 'motherland' of their parents.

Take Jewish identity into account and we are dealing with two imagined communities each of a potentially similar status. Anderson, after all, suggests that nationalism is best treated 'as if it belonged with "kinship" and "religion"' (ibid.: 5). Correlatively, the Jews have been conceived (most usually by their enemies) in terms of a 'nation', and this long before the State of Israel came into being. ${ }^{26}$ 'Jewish identity', furthermore, is a notoriously labile concept. Where a Catholic unbeliever is described as 'lapsed', a secular Jew is nonetheless a Jew in the eyes of many, if not all community members. Whether the Jews of France already had a strong sense of belonging to a Jewish community (be it cultural or religious) or not, the situation in which they found themselves - labelled and marked out as different - served to strengthen, and in some cases create, an imagined community. Although Anderson does not consider how two imagined communities may (or may not) co-exist, he does point out that potentially hybridised identities have long proven to be inimical to those administering the nation state. Commenting here on the census-makers and their 'passion for completeness and un-ambiguity', he points to the latter's 'intolerance of multiple, politically "transvestite", blurred, or changing identifications', concluding: 'The fiction of the census is that everyone is in it, and that everyone has one - and only one - extremely clear place. No fractions' (Anderson 1991: 165-6).

The Jews of France struggle in their accounts with precisely this sort of fractured, 'transvestite' identity, though in their case the census constructed them not just as 'Other' in the sense of 'none of the above', but 'Other' in less benign sense of different, excluded from the community of French citizens. As I write this chapter today, a French Bill forbidding the wearing in state schools of any 'ostentatious' signs or items of clothing (Islamic headscarf or veil; Sikh turban, Jewish 
Deportee identities III: Jewish identity 209

kippa, Christian crucifix) designating the wearer's belonging to a religious faith has just been adopted. French republicanism is once again displaying its aversion to difference, this time, one might argue, turning its attention primarily to the Muslim population. 


\section{Conclusion The case of Charlotte Delbo}

Any reference to the subject matter of this book, whether in France or the UK, has almost invariably provoked mention of one name: that of Charlotte Delbo. In spite, or perhaps because, of her atypical status Delbo appears to have become emblematic of the French female deportee writer in the public imagination. Alongside this popular conception is an established body of critical work: of all the writers in the corpus, Delbo alone has won significant attention from the academy. ${ }^{1}$ However, while her texts have elicited a number of different critical approaches, no one has sought to contextualise her writings visà-vis a broad corpus of French female deportee accounts and to consider why she alone has achieved canonical status. Although a comprehensive study of Delbo's position relative to the corpus falls outwith the remit of this book, by way of conclusion I would like to outline some of the factors which differentiate her accounts from those of the rest of the corpus, basing my analysis on issues raised in each of the preceding chapters. The following discussion focuses primarily on the bestknown of Delbo's deportation texts, the 'Auschwitz et après' trilogy, comprising Aucun de nous ne reviendra, Une connaissance inutile and Mesure de nos jours. ${ }^{2}$

\section{Textual identities}

A return to the questions of Chapter 1 - 'who wrote the accounts?'; 'what is their status vis-à-vis other potentially competing discourses?', 'when and why were they written?' - reveals that Delbo's work departs from the norm in various ways. Her first deportation texts were published at a time when few other accounts were emerging: both $L e$ Convoi du 24 janvier and Aucun de nous ne reviendra (Gonthier) appeared in 1965 (though the latter was written in 1945), ${ }^{3}$ in the midst of what Rousso identifies as a phase of 'repression' of the less savoury aspects of 
the war years in France (Rousso 1990: 19). Aucun de nous was subsequently republished by Éditions de Minuit in 1970 alongside the remaining two volumes of the trilogy, published in 1970 and 1971 respectively. Appearing as it did on the cusp of the phase designated by Rousso as the 'return of the repressed' (the years 1971-4), the trilogy, published by a prestigious publishing house and authored by a woman who already had a place in literary circles ${ }^{4}$ was timely indeed. The fact that Delbo, unlike the vast majority of deportee writers, was a career writer, and that she produced her own corpus of deportation texts - another departure from the norm - has doubtless contributed to both her popular and critical appeal.

Turning to the question 'why?' - an examination of the deportee authors' articulated motives for writing their accounts - Delbo's trilogy reveals the usual topoi, but with some significant differences in emphasis. The desire to commemorate the dead is articulated at several points in the trilogy, but is also a key motivation behind the writing of Le Convoi du 24 janvier, which outlines the background and fate of each member of her convoy of 230 women deported to Auschwitz-Birkenau in January 1943. The need to explore the author's own identity ('writing for the self') emerges repeatedly and insistently in the first two volumes of the trilogy, and is extended to an exploration of the problematic negotiation of the personal identity of other deportees in Mesure de nos jours, which is partly given over to a range of narrators who either remain anonymous or are distinguished by their first names only. (Many of these individuals can be identified as members of Delbo's convoy, though at least one, 'Ida' [M: $100-23]$ is recognisable as the Jewish Ida Grinspan, who was not part of the convoy). ${ }^{5}$ The importance of informing the general public about the camps is repeatedly stressed, but as we will see below, Delbo's approach differs radically from the rest of the corpus authors. Finally, the emphasis on ethical, exemplary memory is more marked, and again handled differently. Where most of those deportee authors who open their accounts out on to other world conflicts do so in the closing pages of their accounts, Delbo introduces different conflicts within the body of her texts. Descriptions of brutal SS reporting officer Anton Taube helping a deportee tie up her shoes, and of Slovene women explaining to Delbo how they came to be part of the SS, are, for example, followed by material quoted from the New York Post of November 1969 reporting on one lieutenant William L. Calley who, having assassinated 109 South Vietnamese, adopted and looked after a young Vietnamese girl (C: 111). The power of Delbo's writing here as elsewhere lies in understatement; in the construction of active 


\section{Conclusion}

readers who are left to draw their own conclusions from the juxtapositioning of material. ${ }^{6}$

It is when we turn to the 'who?' and 'what?' questions, however, that Delbo's texts stand out most markedly from the rest of the corpus. As we saw in Chapter 1, although other writers do raise issues relating to memory and identity in their accounts, with the possible exception of Novac and Crémieux, they do not do so in a sustained or reflective manner, nor do they question the epistemological status of their own texts. Delbo, by contrast, has produced a series of accounts which effectively operate on two levels: the representation of the spatio-temporal world of the camps is complemented by a layer of epistemological inquiry into the nature of identity, truth, memory, and the status of the eye-witness.

Delbo's texts not only provided Langer with the critical tools of 'deep' and 'common' memory (see above, Chapter 1); they offer up a range of images deployed to convey the problematic nature of the status of the deportee, from the trope of spectrality in the opening pages of Mesure de nos jours and elsewhere ${ }^{7}$ (also to be found in the work of Antelme, as Crowley notes [Crowley 2003: 15-20]), to the sloughing off, snakelike, of one skin for another (MJ: 11-12), the deportees' wearing of multiple masks (M: 187), or the powerful image of the returning deportee in Mesure de nos jours:

I envisioned my life as nothing more than a filigreed design or a watermark. I could not tell whether I was the etching on the paper or the pale design you see under it when you raise it to the light.

(MJ: 125; Lamont 1995: 301)

Alongside such explorations of identity, which punctuate all three volumes of the trilogy, Delbo offers critical incursions into the nature of truth and the role of eye-witness. The verbs 'to look at' ('regarder') and 'to see' ('voir') appear obsessively in the trilogy, as the author explores the (im)possibility of witnessing horror in the camps and exhorts her readers to position themselves as secondary witnesses: 'Try to look. Just try and see' (A: 138 and 139; Lamont 1995: 84, 85).

Delbo's preoccupation with the nature of truth in the context of testimonial writing is signalled in the epigraph to her trilogy: 'Today, I am not sure that what I wrote is true ["vrai"]. I am certain that it is truthful ["véridique"]' ${ }^{8}$ The problematic attempt truthfully to represent the past is thereafter brought to the reader's attention via a series of reflexive moments which break into the narration of life in the camps. A description of the deportees in Auschwitz being forced to 
run literally for their lives is thus suddenly interrupted: 'I have no idea whether I reconstituted this whole scene after the fact or if I had an overall concept from the start' (A: 61; Lamont 1995: 36). A section of text describing the narrator's seizing a brief moment to wash in a stream opens with a disclaimer: 'Strange, but I don't recall anything about that day' (C: 52; Lamont 1995: 147). The narration, however, continues, as the author laboriously, and reflectively, represents the scene as it must have been, punctuating her narrative with the logical markers of reconstitution - 'since', 'so, it is quite certain that', 'which means that' - until, finally, after some thirteen pages of description, she returns us to epistemological doubt: 'It must have happened like this, but I have no memory of it. I only recall the stream' (C: 65; Lamont 1995: 153).

Delbo's epistemological explorations are complemented by the articulation of a strong desire to transmit the lived reality of the camps, a desire which, as we saw in Chapter 1 , is more usually expressed in those later accounts whose authors felt that historical discourse had failed adequately to communicate. In this, Delbo was ahead of her time. The verb 'to know' ['savoir'] occurs in the trilogy almost as frequently as 'to look at', and is used to signal the gap between a putative audience's intellectual awareness of the facts of the camps and a truly interiorised knowledge (see above, Chapter 1). A poem in the first volume of the trilogy addresses the reader - 'O you who know' with anaphoric insistence, undercutting the addressee's assumption of knowledge with a series of rhetorical questions: 'did you know that hunger makes the eyes sparkle that thirst dims them?', before concluding with a powerful suggestion that knowledge is not necessarily understanding: 'Did you know that suffering is limitless / that horror cannot be circumscribed? / Did you know this / You who know' (A: 22; Lamont 1995: 11). A poem about Auschwitz in the second volume of the trilogy concludes with further questioning of the status of knowledge: 'Today people know / have known for several years / that this dot on the map / is Auschwitz / This much they know / as for the rest / they think they know' (C: 37; Lamont 1995: 138).

Delbo, then, sets out to inform her readers about the reality of the camps, but how does she go about her task? Like other authors in the corpus she is well aware of the shortcomings of language and of existing paradigms: among the deportees, she states, were authors, 'yet nothing they imagined ever came close to what they see now' (A: 15; Lamont 1995: 6). As we saw in Chapter 2, words lose their meaning in the universe of the camps: "There are people who say, "I'm thirsty". They step into a café and order a beer' (C: 49; Lamont 1995: 145). In 


\section{Conclusion}

Spectres, mes compagnons, Delbo stresses the importance of what she, as a deportee, lived through: 'To me, forgetting means recollection's capacity to reduce the memory of a sensory, living sensation to insensible fact' (S: 23). In her eyes, failure in the testimonial enterprise would consist in reducing the past to an 'anecdote from which the sensory nature of lived reality is gradually expunged' (S: 25). Although, as we saw in Chapter 1, lived reality was also deemed to be the touchstone of 'truth' for the deportee writers, that truth was often regarded as incompatible - in theory if not in practice - with the literary. Consequently, the vast majority of writers in the corpus seek to distance themselves from literary discourse, and their accounts comprise an often uneasy blend of paradigms, combining the 'devices' of realist fiction with textual features drawn from non-fictional genres (footnotes, prefaces, the generic models of the journal and memoir). Delbo, by contrast, goes all out for artifice, for what Semprun dubbed the 'transparent density' required of the testimonial writer. In her attempt to convey the all-important 'sensory nature of lived reality', she embraces the literary wholeheartedly.

A literary analysis of Delbo's writing is beyond the scope of this monograph, and has, in any case, already been undertaken at least in part by a number of critics. Suffice it to say here that some of the key features of Delbo's writing - particularly her use of tenses, metaphor, irony and pronouns - merit further, comparative, study in the context of a wider corpus. What can be said is that Delbo's style differs radically from the norm. Her writing takes the form of highly lyrical prose punctuated with poems (prose and poetry are indeed on occasion differentiated only by typographical layout). As with all poetic discourse, much is left unsaid. Delbo's allusive style relies on an active reader. And an informed one. Readers will find little in the way of discursive explanation in these texts: the implied reader of Delbo's accounts is one who has at least a basic knowledge of the camps. Although the trilogy adheres to a loose chronology (Auschwitz to Raisko to Ravensbrück, and finally the return to France), ${ }^{9}$ linear narrative is replaced by a series of atemporal, predominantly descriptive, fragments based on sensory perceptions, bodily responses. And a further, important, aspect of Delbo's accounts sets her apart from the majority of corpus writers: her highly literary style is also highly selfconscious. The act of writing and the use of literary 'devices' are repeatedly brought to our attention. The author's use of direct speech is, for instance, flagged up by a section header 'Dialogue' (A: 26). The narrative is on occasion abruptly interrupted by a shift to the compositional present: 'Presently I am writing this story in a café - it is 
turning into a story' (A: 45; Lamont 1995: 26); 'I write this as though it were simple' (C: 91; Lamont 1995: 169). Delbo, in other words, knowingly opts for artifice in her attempt to communicate.

\section{Deportee identities}

With respect to the representation of gender and sexual identities the trilogy embraces much of the material encountered in Chapter 3, with some notable exceptions: there is next to no mention of sexualised relationships, no mention of lesbianism or the loathed gynaecological examination, a greater emphasis on violence and punishment, often at the hands of female SS guards. Strikingly, Delbo's representations of male-female relations construct men (significantly, deportees in this case, and not POWs as in most accounts) primarily as figures worthy of compassion, if not pity. A number of sections entitled simply 'The Men', record the appalling physical condition of the male deportees, their greater suffering and lesser capacity for self-help (patience and courage are part of every woman's daily lot; female deportees benefit from those resources 'always possessed by women', C: 11; Lamont 1995: 118). Men in Delbo's texts are often represented as de-virilised: 'They experienced the sting of the decline of strength and manly duty since they could no nothing for the women' (C: 10; Lamont 1995: 17).

Although the trilogy also returns us to familiar ground (enforced nudity, the deterioration of the female body), it is in the manner of representation that Delbo differs most markedly from the corpus of accounts. Her poetic style is, quite simply, immensely forceful both in its economical understatement and capacity for condensation. The following poem, for instance, brings together the topoi of maternity, commemoration, and enforced nudity:

My mother

she was hands, a face

They made our mothers strip in front of us

Here mothers are no longer mothers to their children.

(A: 23; Lamont 1995: 12)

With respect to the representation of the Jews, Delbo (who, presumably because she wrote of Auschwitz, is often wrongly assumed to be Jewish herself), while very occasionally lapsing into stereotypes, avoids any hint of anti-Semitism, and emphasises the specificity of the situation of the Jews more than most other accounts authored by non-Jews. The opening pages of Aucun de nous ne reviendra, which are given over 


\section{Conclusion}

to the arrival of endless convoys of Jews to Auschwitz, avoid essentialisation: these Jews are both secular and religious, they hail from many countries, and from all walks of life. Various subsequent sections of the trilogy focus specifically on Jewish deportees. In both Mesure de nos jours and La Mémoire et les jours the narrative is given over on occasion to Jewish deportees. Delbo is aware of the different conditions faced by Jews and non-Jews. A conversation with a French Jew emphasises Delbo's greater chances of survival. Her half-hearted attempt at reassurance - "'Oh, come on, it's the same odds for both of us"' - is challenged by her interlocutor's gesturing towards the smoke rising from the crematorium chimney (A: 27; Lamont 1995: 15). Although Delbo, on this occasion, could be accused of reinforcing stereotypes of passivity (her emphasis on the need to fight is met with repeated resignation), to overly emphasise this possible lapse would be to misrepresent the trilogy, whose tenor is perhaps best captured in a poem situated immediately after the description of the arrival and selection of Jews in Auschwitz:

You who have wept two thousand years

for one who agonized for three days and three nights

what tears will you have left

for those who agonized

far more than three hundred nights and far more than three

hundred days

$\cdots$

They did not believe in resurrection to eternal life and knew you would not weep.

(A: 20; Lamont 1995: 10)

If the trilogy differs from the norm with respect to the representation of Jewish deportees, so too can it be differentiated in terms of the representation of class, political and national identities. Apart from the familiar metaphor used to describe the hierarchical structures in Auschwitz (the 'block leaders and their assistants, police-women and sentenced German felons' make up the 'aristocracy' of the camp, C: 40; Lamont 1995: 140), class is simply not an issue in Delbo's work. In terms of political identities, although Delbo was herself a resistant and a Communist, her trilogy is highly atypical in its move away from idealism and in its criticism of Communism (the latter being the preserve of non-Communists in the case of the corpus). One poem stresses the justness of the cause: 
Conclusion 217

\author{
When I saw what I saw \\ suffering \\ dying \\ as I saw \\ suffering and dying \\ I realized that nothing \\ nothing was too much \\ in this struggle.
}

(C: 36; Lamont 1995: 137)

But if the cause was just, the brutal reality of war served to remind some of the naivety of self-aggrandisement. The narrator Mado admits that she was 'Silly, naive, yes. Impassioned' (M: 51; Lamont 1995: 259). The heroic image of the resistant is undercut as Mado recalls throwing a message from the train taking her to Auschwitz: 'In one of the notes ... I had written: "I'm being deported. This is the greatest day of my life." I was insane, insane. The heroine crowned with her halo, the martyr going to her death singing' (M: 52; Lamont 1995: 259). Another narrator, Françoise, presumably a Communist, records her disillusionment in the face of news of the Russian camps: 'Why struggle now... now that we know, now that the scandal has surfaced, the lie been unveiled?' (M: 206; Lamont 1995: 348). The penultimate page of the same text comprises a poem which closes on the image of the red flag of revolution tainted by 'a snow of dust / of dirty dust / the color of the present time' (M: 213; Lamont 1995: 353).

Unlike so many of the texts in the corpus, Delbo's works emphasise the strength and importance of French solidarity but avoid mention of French superiority and indeed of national antipathies. Delbo is honest about her own failings (a sense of guilt punctuates the trilogy), and aware of the difference between her living conditions in Raisko ('this privileged commando', C: 86; Lamont 1995: 165) and those of the deportees who remained in Auschwitz. Her contact with Polish deportees - the usual target for hostility, as we saw in Chapter 4 - appears to have been largely limited to educated francophiles (we learn that most of the Poles are francophone and know the Marseillaise better than the French, C: 95, 101). On only one occasion does she record a hostile act (a Polish deportee refuses to give her water, A: 121). Watching male deportees pass by, Delbo fleetingly wonders what nationality they are, before concluding that they are, quite simply, men: 'Poles? Russians? Pitiful men, oozing misery like all men here' (A: 36; Lamont 1995: 21). Standing in ranks, the female deportees share a single heartbeat; 


\section{Conclusion}

they are joined together by 'a single circulatory system' ['une même circulation, un même réseau sanguin'] (A: 103; Lamont 1995: 63).

\section{Canon vs. margin?}

The (re)reading of Delbo's canonical deportation texts in a new context - that of a wider, marginalised corpus of French female deportee accounts - which I have merely sketched out here, leads to the following conclusions. First, Delbo's texts are, to employ a term which brings its own critical baggage, 'politically correct' in comparison with many accounts in the corpus, perhaps especially those written by nonJewish deportees. With respect to the issue of 'deportee identities' explored in Chapters 3 to 5 , there are next to no hostile representations of other national groups in Delbo's work, no attempt to represent the French in laudatory terms nor to single out resistants as morally superior, no class distinctions and no anti-Semitism. (Indeed, by speaking of and for the Jews as extensively as she does, Delbo could be said to have represented the specificity of the Jewish experience long before Jewish memory came to the fore.) To return to the issues raised at the close of Chapter 4, Delbo's accounts represent a highly inclusive concept of community with none of the fractured solidarities seen in the majority of accounts. When Delbo states that 'aucun de nous ne reviendra', the first-person plural pronoun embraces all deportees, of whatever nationality, gender, class, political or religious affiliation.

Second, and here we return to the question of 'textual identities' discussed in Chapters 1 and 2, Delbo's accounts are unashamedly, and unambiguously literary in nature. Not only does Delbo write well (a distinction which it must be said cannot be extended to the majority of deportees), she has produced texts which avoid the uncomfortable straddling of genres common to the majority of testimonial texts in the corpus. Deemed to be too literary and too subjective to be of use to historians, most accounts in the corpus are at the same time not literary enough to 'pass' on purely aesthetic grounds. They are also and this is important - not easily classified by publishers whose lists all too often demand a certain generic specificity. Delbo's stylish writing, combining descriptions of the lived experience of the camps with a layer of epistemological enquiry, offers rich fodder for the critics, engages readers on an aesthetic level, and provides sufficient though far from extensive - detail about the camps to fulfil an informative function. Add to this the fact that they are available in translation and thus capture the large Anglophone (Holocaust) market, and her success is unsurprising. 
I do not wish to end this book by reiterating Delbo's capacities and achievements as an author: these are not in doubt. Her deportation accounts, however, do have their limitations. In short, the Auschwitz trilogy may be accessible to all sorts of readers but it is quite simply not representative of experience in the camps as communicated by the majority of French female deportee authors. Where Delbo's texts present the reader with what might almost be termed a bracketed phenomenological subjectivity 'emptied' of ideology, the corpus reveals that deportee identities - gendered, sexual, national, political, class, Jewish - are constructed and represented in specific contexts, and that these constructed identities, whatever we might like to believe, led more often than not to conflict, tensions and fractured solidarities. Where Delbo's accounts reveal the aesthetic skills of an accomplished writer, the corpus shows us the perhaps rather more interesting phenomenon of individuals striving to communicate in writing perhaps for the first and only time in their lives; struggling, albeit unreflectively, to achieve a 'truth' caught between subjectivity and objectivity, artifice and actuality, lived experience and history. Although - or indeed because - they are undoubtedly less aesthetically accomplished, ultimately, I would suggest, these accounts are perhaps more 'truthful', and certainly merit greater attention than they have hitherto been afforded. 


\section{Notes}

\section{Introduction}

1 For a discussion of the Vel d'Hiv commemoration and Mitterrand's Resistance past, the 'Jewish file', the trial of Touvier, the Moulin controversy and the 'father Pierre' negationism controversy, see Rousso and Conan (1996).

2 For a comprehensive time-line of incidents and events surrounding France's 'memory' of Vichy from 1990-5, see Rousso and Conan (1996: 461-79).

3 The role and status of the witness, and Conan's and Rousso's position are discussed below, Chapter 1 .

4 Wieviorka (1992) is a rare exception, although the analysis of testimonial accounts constitutes only one part of her study of deportation and genocide. See also her shorter pieces (1989, 1994a, 1994b). Parrau (1995) and Pollak (1998) also analyse deportee accounts, but focus on a limited number of authors, many of them male.

5 Monographs focusing on women writers include Baskin (1994), Bendremer (1997), Brenner (1997), Fuchs (1999), Hardman (2000), Heinemann (1986), Laska (1983), Ofer and Weitzman (1998), and Rittner and Roth (1993).

6 The qualifier 'political' as applied to the deportees is explored further in Chapter 4. I have used the more general term 'Auschwitz' (comprising the three principal camps, including the women's camp Auschwitz-Birkenau) in preference to 'Auschwitz-Birkenau' throughout.

7 Klarsfeld (1978: unpaginated).

8 Created in 1990, the Fondation pour la mémoire de la deportation (website: http://www.fmd.asso.fr/) includes in its mission statement the compilation of a 'Livre-Mémorial' comprising lists of all convoys of political deportees leaving France, a preliminary version of which has been compiled.

9 Figures cited by Wieviorka (1992: 20-1).

10 LaCapra's position is explored further below, Chapter 1.

\section{Textual identities I: the epistemological status of the eye-witness account}

1 This statement, which stands alone on an unpaginated left-hand page, precedes the account's prefatory material and includes a replicated signature of the author. 
2 Wieviorka cites Gouri, La Cage de verre (Paris: Albin Michel, 1964: 296). On the survivors' physical presence itself constituting a form of 'testimony', see also Horowitz (1992: 48).

3 The account combines Poirot-Delpech's third-person narrative with extensive first-person quotation of Grinspan's own narrative.

4 See below, Chapter 2, where it is suggested that any emotive departures from impassivity may indeed threaten verisimilitude.

5 See also the work of Cathy Caruth (1995, 1996), whose terms 'traumatic recall' and 'conscious recall' are very similar to Langer's 'deep' and 'common' memory.

6 For a critique of Langer's stance, specifically of his representation of oral testimony as unmediated and authentic, and his failure to question his own role as a secondary witness, see LaCapra (1994: 194-200).

7 For Delbo's discussion of 'deep' and 'ordinary' memory, see Delbo (1995b: 13-14).

8 'Selection' in this context refers to the process whereby those deportees deemed unfit for work (or arbitrarily picked out) by the SS guards or doctors were taken to their deaths.

9 See especially LaCapra (1998), Chapter 1, 'History and Memory: In the Shadow of the Holocaust', and Chapter 6, 'Conclusion: Psychoanalysis, Memory and the Ethical Turn'; and (1994) especially the concluding 'Acting Out and Working Through'. See also S. Friedlander (1994).

10 For further reading, see Alun Munslow (1997); Keith Jenkins (1991, 1995), and for a more ethical slant (1999). For the other side of the debate - i.e. a defence against postmodern approaches to historiography, see Richard J. Evans (1997).

11 For a discussion of Rassinier and Faurisson, see Lipstadt (1993: 51-64, on Rassinier); (ibid.: 160-4; 173-6; 224-7, on Faurisson). Faurisson is also discussed in Rousso (1990: 176-83), as is Darquier de Pellepoix (ibid.: 163-8). In June 1985 the University of Nantes awarded a doctoral degree to Henri Roques in which he refuted the claims of Kurt Gerstein, one of the individuals involved in informing the Allies about the gas chambers. Roques's thesis was revoked in 1986. Jean-Marie Le Pen's negationist claims came to a head in the late 1980 s, including most famously his statement in 1987 that the gas chambers were 'a footnote in the history of World War II', and his reference in 1988 to former socialist minister Michel Durafour as 'Durafour crématoire'. For a recent discussion of negationist claims, see Richard J. Evans's account of his role as expert witness in the court case involving Holocaust denier David Irving (2002).

12 For a discussion of Hayden White's postmodern position, see Jenkins (1995: 134-79) and (1999: 115-32). See also White (1997: 392-6) for his engagement with the problem of representing the Holocaust within a postmodern paradigm.

13 See Eaglestone (2001) for an analysis of postmodernism as a weapon in the fight against Holocaust denial.

14 For a discussion of French negationist Paul Rassinier's exploitation of inconsistencies in WWI eye-witness accounts recorded by Norton Cru, see Dulong (1998: 91-2). 


\section{Notes}

15 Wilkomirski's Fragments: Memories of a Childhood, 1939-1948 was published in 1996 and called into question in 1998. In a paradigmatic confrontation of 'memory' and documentation, the latter was to prove that Wilkomirski's account was indeed a falsification. For a full discussion of the case, see Maechler (2000).

16 Transcripts of the Eichmann trial can be consulted on-line at: http://www.nizkor.org/hweb/people/e/eichmann-adolf/transcripts/html

17 For her analysis of the Eichmann trial, see Wieviorka (1998: 117-26).

18 The film Holocaust was broadcast in the USA in 1978. Twenty-eight other countries, including Germany, immediately bought the rights, but France did not. The film was finally broadcast in France between 13 February and 6 March 1979. For a discussion of the impact of the film, see Rousso (1990: 168-70) and Wieviorka (1998: 129-31). Testimonial accounts by both Louria (1979: 9) and Serre (1982: 5) mention the film in relation to these authors' decision to publish.

19 For a discussion of the controversy surrounding Mitterrand's past and accusations levelled against Moulin, see Conan and Rousso (1996: 256-349).

20 Wieviorka would appear to be mistaken when she states no notes were taken in situ at Birkenau, (1992: 194).

21 As the bibliography of primary texts indicates, several authors in fact published their accounts privately.

22 Touboul makes a similar alteration, changing the early edition's 'the "kapos" also sing patriotic military marching songs' (1982: 79) to 'sing Nazi military marching songs' (1997: 104). On the other hand, Vidal Naquet, prefacing Heftler's $S i$ tu t'en sors, points out:

Some publishers to whom Nadine Heftler offered her manuscript wanted her to change the word "Krauts" to "Germans" or "Nazis". This would have been a timely correction if the book had been published in, say, 1950. Such a change made absolutely no sense in 1992.

(1992: v)

Camus famously stressed the difference between 'German' and 'nazi' in his Lettres à un ami allemand: 'When the author of these letters says "you" [vous], he does not mean "you Germans" but "you Nazis"' (1972: 16).

23 For a full discussion of the evolution of the teaching of the war years in French schools, see Rousso and Conan (1996: 350-94).

24 Deportee association newsletters of the period such as Le Patriote résistant abound with similar anti-rearmament and anti-EU sentiments. 


\section{Textual identities II: the accounts as textual constructs}

1 Reiter notes that the notion of the 'unspeakable' or 'trope of unutterability' is itself a rhetorical device (2000: 18). Berel Lang likens the ('figurative') claim that something is unspeakable to the rhetorical device of 'praeteritio': a speaker states that s/he will not speak of something when it becomes obvious that the very purpose of denial is to do just that (Lang 2000: 17).

2 Just what 'sufficient' artifice means, is, of course, open to question. For a vitriolic attack on the growing trend in the 1950 s for fiction based on concentration camps, see Cayrol (1953).

3 On arrival in the camps deportees had to display inverted coloured triangles on their clothing: red for 'political' prisoners; green for criminals; black for 'asocials'; purple for Jehovah's Witnesses; pink for homosexuals; blue for emigrants; brown (or black) for gypsies; a yellow Star of David for Jews. 'N.N.' - 'Nacht und Nebel' - was the name of an order issued on 7 December 1941 to seize individuals endangering German security; if not executed immediately, these individuals - in this case French resistants and Communists - were to vanish without trace (hence the name). See Bédarida and Gervereau (1995: 49-52).

4 All deportees assigned to camps (those who were not, as in Auschwitz and other death-camps, killed immediately upon their arrival) received a number or 'matricule', which had to be displayed on their clothing; the Jews in Auschwitz were also branded with a tattoo bearing their camp number.

5 'Rémy' was Gilbert Renault (1904-84), a legendary figure in the Free French Forces, responsible for co-ordinating networks in France and liaising with de Gaulle.

6 Bertrand Poirot-Delpech (1929-), journalist with Le Monde, novelist, and essayist, elected to the Académie française in 1986; Lucien Neuwirth (1924-), member of Free French Forces, subsequently engaged in a political career; Jacques Chaban-Delmas (1915-2000) also a member of the Gaullist resistance, and prominent in the liberation of Paris, subsequently President of the 'Assemblée nationale'; Maurice Schumann (1911-98) member of, and (radio) spokesman for, de Gaulle's Free French, subsequently engaged in a political career, elected to Académie française in 1974; Robert Chambeiron, friend of Jean Moulin and deputy secretary of the National Council of the Resistance; Marcel Conche, philosopher and university professor; Stéphane Courtois, university professor and author of (inter alia) Le PCF dans la guerre and L'État du monde en 1945 (with Annette Wieviorka); Jean Nocher, another (relatively) high-profile Gaullist Resistance figure, author of Les Clandestins, 'utopianist', perhaps best known for his 1946 radio spoof 'Plate-Forme 70' describing the aftermath of a nuclear explosion.

7 The red triangle with the letter ' $F$ ' indicated that the deportee was a French 'political' deportee (of whatever persuasion). Améry is not specific about which deportees she refers to here. If she refers to the French, her figure is close to that of the percentage of French Jews who returned to 


\section{Notes}

France ( 3 per cent), but vastly underestimates the number of French political deportees who returned (estimated at 59 per cent).

8 See also Wieviorka (1992: 188); Reiter (2000: 150).

9 De Gaulle-Anthonioz was moved to the Bunker in late October 1944 for 'safe-keeping' as a privileged prisoner and potential hostage. She was released from the camp some four months later on 28 February 1945, alongside Virginia d'Albert Lake, a young American who had participated in the Resistance. See Tillion (1988: 316), and Rothman-Le Dret (1994).

10 Catherine Roux's Triangle rouge constitutes a notable exception. This is a highly literary, stylised, and formally complex text, which although articulated around a chronological axis, is punctuated by various sub-genres (parables, extended metaphors, prose poems, vignettes).

11 Although there is no indication of genre in the titles or subtitles, Novac, Alcan and Saint-Clair all refer explicitly to their texts as journals (Alcan in her foreword; Novac throughout the text; Saint-Clair in her afterword, 1945: 207).

12 Other deportee writers are considerably less critically aware (and indeed punctilious) with regard to their use of second-hand reports. Gorce, for example, provides an account of the Auschwitz gas chambers (1995: 106-7), in which second-hand reportage (her source is a former Auschwitz detainee) slips unsignalled into imaginative reconstruction: 'Slowly, the gas begins to take effect. Terror is at its height. The mother hugs her child a little tighter' (ibid.: 107). Although this is an extreme example, it is not uncommon for second-hand reportage to glide smoothly (and almost imperceptibly) into what appears to be an eye-witness description of events.

13 As Young points out, although the journal may appear to be 'ontologically privileged" in comparison to the memoir, it is, in fact, "no more "real" or "authentic" for that, if we take these terms to denote factual veracity' (1988: 33). See also Young (1987b: 414-20) for further discussion of the journal.

14 According to Young:

In moving from the legendary realm of Genesis to the historical world of Exodus, for example, the biblical scribes seemed to devote considerable effort to reinforcing the testamentary - that is, eyewitness - authority of their narrative ...

Faced with the implicit arbitrariness of their narrative ... the scribes of the Pentateuch seem already to have been experimenting with rhetorical and literary strategies for reinforcing their text's historical authority. As is true for subsequent documentary narrative, the operative trope and principle of Holy Scripture here is thus its explicitly eyewitness character as edut - that is, testimony and evidence.

(ibid.: 408, 409)

15 See Pollak's somewhat hostile assessment of Novac's account:

This reflexive tendency limits the impact of her message and, correlatively, contributes to the unease with which we read her text: the reader's inability to reconstruct the reality of events, which are 
masked by the abundance of personal feelings expressed, is in marked contrast with the usual tone of testimonial accounts, the legitimacy of which is not an issue given the weight of facts which saturate such texts.

16 Reiter identifies the key function of the concentration camp journal as 'to inform posterity of their [the authors'] own and their fellow-captives' existence' (2000: 53-4). Rachel Brenner, however, stresses the importance of self-examination, pointing out that the journal allows its author to look back at her self as manifested in earlier entries, (1997: 139).

17 Jeannin-Garreau explicitly articulates the shift in her account from a personal to a collective narrative: 'The personal part of my adventure, that which I had to experience alone, ends here ... from this point on events take place within a community' (1991: 28).

18 'Testimonio' emerged as an important part of Latin American's postboom literature, and was originally regarded as the testimony of the oppressed, and as a highly politicised genre which operated outwith both the political and literary centres, though this situation has since evolved. Perhaps the principal difference between the testimonio as originally conceived and the testimonial texts we are dealing with here lies in the often oral nature of the former, many examples of which involved the third-party transcription of narratives produced by witnesses who were in many cases illiterate.

19 Three other accounts which depart to varying degrees from the 'norm' might be mentioned here. Asseo's Les Souvenirs d'une rescapée (1974) opens with an account of the author's upbringing before shifting to the present (1958), and the author's meeting a young man on a boat trip. Upon hearing the words 'Why don't the five of us sit down to eat?' (1974: 29) Asseo is reminded of the camps (where deportees were regularly lined up in fives), and subsequently begins to tell her interlocutor the story of her deportation in flashback form. This narrative frame is never closed. Crisimily's Traumatisme psychique (1981) opens with an account of the author's childhood, moving through several sections on the author's childhood, arrest, deportation and finally retirement, but the latter section is severely truncated. Aylmer-Roubenne's J'ai donné la vie dans un camp de la mort (1996) begins just before the author's marriage, proceeding through an accounts of Aylmer-Roubenne's deportation, to a lengthy post-liberation section (ibid.: 147-204) recounting the author's remarriage and the birth of a second child, Sylvie. Pages $178-88$ comprise a secondary narrative written by her daughter, Sylvie.

20 Reiter references Langer (1982: 74-94).

21 See also Ezrahi's discussion and comparative study of Holocaust 'documentary novels' and memoirs (1980: 24-48, 49-66).

22 Louria represents an interesting case in this respect. In her Les Russes sont à Lemberg the author states that although she has been entirely truthful in the essentials of her account, she decided to create a 'happy ending': 'I chose a happy ending, the one I had dreamed of from the moment I arrived in the camp' (1979: 9-10). 


\section{Notes}

23 Much of what the deportees have to say runs counter to Langer's claims (though one must not forget that his assessment is based on Jewish survivors). In his Versions of Survival Langer challenges critics such as Frankl, Bettelheim and Des Près for their claims that 'heroic gestures' might emerge in the camps, or that the deportees might discover newfound 'inner resources', preserve a degree of dignity, and fight the dehumanisation of the camps. Langer insists that nothing about the 'extreme situation' of the camps could ever lead to spiritual growth (1982: 17).

24 For a related discussion of truth and verisimilitude, see Grierson (1999: 207-24).

25 See Young's articulation of the testimonial writer's dilemma:

The possibility that, once committed to paper, a witness's testimony could be perceived as a fabrication of reality and not the trace of it he had intended, would seem to mock a witness's very raison d'être. And to compound the dilemma, the more insistently a survivorscribe attempts to establish the 'lost link' between his text and his experience in the text, the more he inadvertently emphasises his role as maker of the text, which ironically - and more perversely still further undermines the sense of unmediated fact the writer had attempted to establish.

(1987b: 413-14)

26 According to Pollak, the tendency to produce 'heroic' narratives is largely restricted to male writers (1990: 211-12).

27 The anonymous author of this problematic text states that she was arrested on 9 July 1943. Working on the basis of information provided, we can calculate that she had arrived in Auschwitz by 16 August 1943. The author gives her camp number as 55.310, but according to Klarsfeld's convoy listings (and assuming the author was deported from France), convoys arriving in Auschwitz at that date did not receive numbers in this sequence (deportees in convoy 57, leaving Drancy on 18 July 1943, received camp numbers 50204 to 50394; those who were part of convoy 58, leaving on 31 July 1943, received numbers 52297 to 52351).

28 For a discussion of pronoun use in testimonial accounts, see also Parrau (1995).

29 LaCapra mentions the 'victims" use of 'gallows humour' in a brief but interesting discussion of the carnivalesque (1994: 222).

30 Cited in Langer (1978: 51).

31 Ezrahi (1980: 55) and Reiter (2000: 107) both refer to the potential dangers of analogy. For Young, however, it is crucial not to 'mystify' the Holocaust by claiming that it lies outwith all analogy, archetypes and paradigms. Archetypes, for instance, may be invoked and subsequently modified or subverted (1987a: 282) and (1988: 95).

32 The amount of intertextual and metaphorical material of course varies from text to text. Some accounts, such as Roux's Triangle rouge are heavily metaphorical, and include a number of extended metaphors which often 
run over several pages. Such use of the extended metaphor is, however, atypical, as Reiter points out (2000: 101), though it can be found in a small number of other texts, including Wilborts (1946).

33 For a discussion of the use of Dante as an intertextual reference in the work of Primo Levi and Peter Weiss, see Arrigo Subiotto (1991: 70-89).

34 See Reiter (2000: 108) on what she terms the 'puppet-play' metaphor.

35 Reiter mentions Holocaust criticism which 'holds that the concentration camp experience actualized the realm of the symbolic. "It is as if amid the smoke of burning bodies the great metaphors of world literature were being 'acted out"', writes Terence Des Prè's (Des Près, 1976: 70, 174)' (Reiter 2000: 95).

36 Marijo Chombart de Lauwe, cited in Guidez (1989: 314-15).

\section{Deportee identities I: gender and sexuality}

1 See Hardman (2000) for a useful critical overview of gendered approaches to Holocaust studies.

2 Originally published in Ringelheim (1985: 741-61). For an earlier less self-critical approach from Ringelheim, see her work (1984: 69-87).

3 See also Horowitz (1998: 365-77).

4 The term 'prisoner-functionary' is taken from Sofksy (1997) and designates any deportee (chosen by the SS authorities and) placed in a position of authority over other deportees.

5 'Since it was impossible to keep a formal check on work sites remote from the camp, guarding was ultimately dependent on the moods of the guards and the arrangements of the various sentries' (Sofsky: 1997: 112).

6 Abadi (1995: 100) describes the same scene.

7 References to the call for 'volunteers' can be found in many of the Ravensbrück accounts, including Brun (1979: 170) who describes how she herself narrowly escaped selection for a brothel. The situation in Auschwitz is described by Ourisson (1947: 22-4) and mentioned in Marie-Claude Vaillant-Couturier's Nuremberg deposition (1946: 15).

8 For texts which focus primarily on male homosexuality, see Plant (1986); Boisson (1988); Grau (1995); Le Bitoux (2002). In 1989 Bitoux created the 'Mémorial de la Déportation Homosexuelle'. The 'Fondation pour la mémoire de la déportation' lists 210 French men deported as homosexuals. Rudolf Hoess refers at some length to male homosexuals in his autobiographical account (2000: 93-7). Schoppman (1996) discusses German lesbians both within and outside the camps. Morrison includes a short section on female same-sex relations (2000: 129-33).

9 For a discussion of lesbians and jail culture in France, see Sautman (1990: 177-201).

10 For a discussion of lesbian relationships in the Gulag, see Zhuk (1994):

Most first-time female offenders have no earlier lesbian experience. They fall under the influence of more experienced inmates who have been in prison or camps for years. These women, who have usually been convicted more than once, offer a set pattern of sexual relationships: the active partner - kobyol (butch) - and the passive 


\section{Notes}

one - kovyryalka (femme) ... Kobly behave like men both socially and in their intimate lives. ... In intimate relations the role conduct of the kobly is an attempt to imitate men.

(ibid.: 149)

11 The partners of the 'masculine' 'Jules' are rarely named. Le Guillerme and Blanc are exceptions: the former refers to the 'male [mâles] lesbians' as 'Jules' and the 'females [femelles]' as 'Julie' (Blanc 1984: 215); 'in the afternoons the Jules shut themselves in the sleeping area and are visited by their Juliettes...' (le Guillerme 1946: 257).

12 As Sofsky points out, the system of classification by triangle tended to reinforce stereotypic perceptions: 'Like every categorial differentiation, the color system guided social judgment by intensifying the perception of differences. Persons of the same category seemed more similar to each other than persons of different categories. The imposed class system channelled social perception' (1997: 123).

13 There is no record of any French woman bearing a pink triangle in any camp, though Vichy legislation did theoretically penalise certain lesbian acts. See Copley (whose main focus is male homosexuality) (1989: 200-4).

14 Although no names appear in her version, Fabius seems to allude to the same couple (1986: 182).

15 The trope of contamination can also be found in Hoess: 'Like homosexuality among the men, an epidemic of lesbianism was rampant in the women's camp [at Auschwitz]' (2000: 139, my emphasis). Vera Laska (implicitly invoking the stereotype of the 'pis-aller' as well as a hint of 'contagion') suggests that lesbian relationships were most likely to form if the putative couple involved a 'real lesbian': 'Stripped almost totally of male companionship by the division of sexes, women formed warm relationships with one another. Occasionally, these relationships developed into Lesbianism, especially if one partner was a bona fide Lesbian' (1993: 263).

16 See Hardman (2000: 20-7) for a critique of Fénelon's account and the dispute which arose between Fénelon and Anita Lasker-Wallfisch, identified by Hardman as the figure behind 'Marta' in Fénelon's account.

17 Mallet singles out the Germans as the only national group to engage in same-sex relations: 'We, the French, and deportees of all other nationalities were not troubled by such dubious thoughts' (1949: 87-8).

18 Blanc recounts a similar incident involving Lily de Rothschild and her bed-partner (1984: 135).

19 The most common image involving the shaving of women's heads remains, perhaps, that which occurred post-liberation to those woman accused of collaboration during the 'épuration'. For gender-based analyses of the shaving of women's heads at this time, see Virgili (2002).

20 Paul escaped alongside Odette Fabius. Both deportees' accounts describe the event and repercussions.

21 See Les Françaises à Ravensbrück (1965: 147-62).

22 The same incident is referred to by Roux (1946: 133), BouteilleGaragnon (1946: 234, 293-4), and Bauer, who names one of the women as Françoise Michel-Lévy (1993: 155-6). 
23 The incident is also described by Thérèse Chassaing in Bloch (1946: 185-6) and by Lévy-Osbert (1992:126-7).

24 Lahaye returns to this episode in her Les Rachetées (1963: 72-3), in which she refers once more to 'Cécile' and 'Armelle'. Améry's version of events, however, seems to reinforce what the reader of Les Rachetées may have suspected, i.e. that 'Cécile' is, in fact, Lahaye herself:

'You may go to the toilet'. What a relief! We've been working since six o'clock in the evening. Everyone rushes over. But an SS guard appears. Our haste has annoyed her. She starts lashing out. Simone Lahaye receives a blow. She tries to hit back. Armelle rushes over to help her.

(Améry 1945: 72-3)

It may be that Lahaye had anticipated that the representation of 'heroic' behaviour (fighting back against the SS) would be more acceptable to the reader if presented in the third-person (see Chapter 2 above).

25 See Haffner (1946: 49). Busson has a different take:

Some psychologists see this as a real mental illness: an obsession with eating which stifles all intellectual activity. I do not believe that this is so. It is distraction; a means of invoking one's family life and the customs of one's country.

(1946: 95)

26 For a discussion of women's lives in Nazi Germany, see Bridenthal et al. (1984) and Owings (1993).

27 For a full discussion, see Muel-Dreyfus (1996).

28 On women and survival stratagems including keeping clean etc., see Karay (1998: 305-7).

29 Les Françaises à Ravensbrück (1965: 203).

30 In Les Françaises à Ravensbrïck it is suggested that three French babies survived: Jean-Claude [Passerat] (1965: 207, 210), Sylvie R... (ibid.: 210) and Guy Poirot (ibid.: 211). 'Sylvie R...' is Sylvie Roubenne, daughter of Madeleine Aylmer-Roubenne, whose states in her account that her daughter and Guy Poirot were the only two French babies who left Ravensbrück alive (1996: 88).

31 For further information on children in the camps, see (for Auschwitz) Kubica (1998: 412-22); for Ravensbrück, Morrison (2000: 262-74) and Les Françaises à Ravensbrück (1965: 211-17).

32 See Lifton and Hackett (1998: 301-16), and for more extensive fuller documentation, Lifton (1986).

33 Hautval also worked alongside Drs Wirths, König, Rhode, and Mengele. For further accounts of 'doctors' in Ravensbrück, see Truck (1975, 1976). 
230 Notes

\section{Deportee identities II: nationality, class, politics}

1 Huk, for instance, records that a French deportee became a Blokowa at Limmer camp (1958: 150); Bouteille-Garagnon refers at some length to Else, a French Blockalteste at Holleischen (1946: 199), as does Roux (1946: 74).

2 For a discussion of Polish perceptions of this failure, see Davies (1981: 431-2).

3 Morrison somewhat unaccountably includes Jews (15.1 per cent) and gypsies (5.4 per cent) as separate 'national' categories in his list (2000: 86).

4 Tillion makes a similar observation (1988: 210).

5 Ascheron continues:

There was some background to this: the French and Polish royal families had intermarried, French had become the polite language of the great Polish aristocrats, and Poland had drawn many ideas from the Enlightenment and the Revolution of 1789 before its fall. Afterwards, Napoleon supported the Polish cause (for his own ends), and for most of the nineteenth century French governments not only welcomed Polish exiles but loudly endorsed their calls for a restoration of independence.

(1987: 8)

6 For discussion of role of Józef Pilsudski, see Ascheron (1987: 12-14; 45-50; 68-77) and Zamoyski (1987: 328-50).

7 The 'schmoustiques', the francophone version of 'Schmuckstücken', comprised those deportees in such a degraded physical condition that their chances of survival were practically non-existent. See Tillion (1988: 193-5).

8 Jackson estimates that by 1944 approximately 185,000 French workers had volunteered to work in Germany, motivated by 'the prospect of higher wages and reports of good working conditions' (2001: 297-8).

9 See, for example, Gildea (2002: 394-5).

10 For a comprehensive discussion of the Resistance, see Jackson (2001: 385-523). For an analysis of various tensions and conflicts, including those between local and national perceptions of the Resistance, see Gildea (2002).

11 See Jackson on the Communists (2001: 419-25; 536-41) and, for an analysis of the status of the deportees and conflicts arising among the various post-war deportee associations, Wieviorka (1992: 121-57).

12 A similar sentiment is expressed in Kessel's L'Armée des ombres in an exchange between Gerbier and Legrain: "Goodbye, comrade [camarade]", said Gerbier quietly. Legrain whirled round to face him as though he'd been scalded. "You're... You're... a communist", he stammered. "No, I'm not a communist", said Gerbier. ... "But that doesn't mean I can't have comrades/friends [camarades]"' (1963: 21).

13 See also Bloch (1946: 156) on Communist propaganda in Auschwitz. 
14 This anomalous convoy of 230 French women deported as 'political' prisoners was sent to Auschwitz-Birkenau (rather than Ravensbrück) on 24 January 1943. See Delbo (1965).

15 Blanc, by contrast, singles out 'Marie-Claude V...' as 'one of the rare communists who helped others out without concern for their political loyalties' (1984: 264).

16 Rousset's text, 'Au secours des déportés dans les camps soviétiques: un appel aux anciens déportés des camps nazis', appeared in the Figaro littéraire of 12 November 1949. For further discussion of Rousset's stance and the criticism of Communists in Buchenwald, see Crowley (2003: 45-8).

17 Todorov identifies Marie-Claude Vaillant-Couturier as one former Communist deportee who refused to take a stand against the Soviet camps: 'If they [she and other former deportees] refused to take a stand against the Gulag it was not because their memory failed them; it was because their ideological principles precluded their doing so' (1998: 49).

\section{Deportee identities III: Jewish identities}

1 Accounts by Cynamon-Goldenberg, Grand, and Jacobson are also mentioned below, though none of these accounts extends to a discussion of the camps (neither Cynamon-Goldenberg nor Grand were deported; Jacobson was selected for death on arrival in Auschwitz).

2 Of the 24,500 French nationals 8,000 were French born, 8,000 naturalised, 8,000 children born to foreign parents and French by parental declaration, with 500 unaccounted for (Klarsfeld 1978: unpaginated).

3 Cynamon-Goldenberg, taken from Paris into hiding in Normandy aged eight, records that her she was baptised as a safety precaution: 'A splash of water on the right, another on the left. In the name of the father and the holy ghost and there you have it, Sylvie, you're one of us. A little white wafer and all debts are duly paid' (2002: 21). Reintegrated after the war into her extended family (she avoided deportation), Cynamon-Goldenberg 'became a Jew again' (ibid.: 31).

4 Imposed by Vichy in November 1941, the Union générale des israélites de France was a body charged with representing the Jews of France. A controversial institution from its inception, it was seen by many as a cog in the Vichy regime which served to facilitate the identification and arrest of Jews.

5 Le Pen notoriously referred to Auschwitz as a detail, or footnote to history in a campaign speech of 1987.

6 Marcelle and Francine Christophe were deported to Bergen-Belsen; Fabius and Crémieux, although Jews, 'passed' as non-Jews and were deported to Ravensbrück.

7 Morrison is incorrect when he claims that No female prisoners were involved in either the construction or the operation of the gas chamber at Ravensbrück' (2000: 289). As Tillion notes, French members of a painting and construction work-detail were indeed involved in work on the building which was to become the gas chamber (Tillion 1988: 346-7). For a first-hand account of a French deportee helping to construct 


\section{Notes}

the gas chamber, see Hugouneng (1981: 1). For details of exterminations by gas at Ravensbrück, see Tillion (1988: 329-60).

8 See also J.-C. Pressac and R.-J. van Pelt, "The machinery of mass murder at Auschwitz' (1998: 183-245).

9 Jews initially (1939-early 1942) comprised approximately 10 per cent of the population in Ravensbrück. As of autumn 1942 they were deported East in accordance with measures to render the Reich 'Judenfrei'. See Morrison (2000: 69-71) and Wieviorka (1992: 238). Tillion suggest that the movement of Jews in and out of Ravensbrück was, in fact, more fluid (1988: 335).

10 Three groups of French political prisoners were transferred from Auschwitz (Raisko) to Ravensbrück: eight left Auschwitz on 7 January 1944, thirty-five on 2 August 1944, and another seven arrived on 14th August 1944. See Delbo (1965: 20-1).

11 Nordmann makes a similar point, stressing the selection process on arrival, longer roll-calls, reduced rations, harsher punishments and labour: 'But if the camp was terrible for everyone, no adjective can describe what it was like for those poor women ... labelled as Jews by the Nazis and singled out by them as targets of their sadism' (in Bloch 1946: 110-11).

12 According to Wieviorka:

designating all the deportees as 'political deportees', including those deported on racial grounds, marked a return to the republican tradition which required that Jewish identity remain in the domain of private religious practice, and that no mention of it should ever be made on official documents. If the ministry had established a category entitled 'Jewish deportee' or 'racial deportee' ... Jewish organisations would probably have protested with great vigour.

(1992: 67)

13 Wieviorka cites the same passage (ibid.: 244).

14 Hélène Solomon (née Langevin) was transferred to Ravensbrück on 14 August 1944; Henriette Mauvais, Simone Sampaix and Marie-Claude Vaillant-Couturier on 2 August 1944. See Delbo (1965: 195; 262; 269; 282).

15 Hautval was jailed when she spoke out against the ill-treatment of a Jewish family and refused to withdraw her support (1991: 11). See also Delbo (1965: 141).

16 Du Fresnes's outspoken support of the Jews resulted in her incarceration in Beaune-la-Rolande internment camp.

17 Finkielkraut notes that only two types of European Jew existed in the public imagination at the start of the war: 'white, Western, normal ones', who spoke the national language, and 'Jews from the olden days, picturesque throwbacks and medieval remnants' who 'expressed themselves in Yiddish, and found nothing better to do as their hour of doom approached than to don their ceremonial shawls and sway rhythmically in prayer' (1994: 40).

18 See Caron (1999: 64-93; 268-301). Such terminology went back a long way: Birnbaum refers to Édouard Drumont's descriptions of the Jews' 
arrival in France (in the 1880s) in terms of both invasion and illness (P. Birnbaum 1995: 112-17).

19 See Finkilkraut (1994: 57-80).

20 Class distinctions are also raised by Louria, who describes the antagonism between French Jewish deportee Nathalie, only child of a rich diamond merchant who had lived in luxury on the avenue Foch, and Julie, daughter of a street vendor who had lived in Belleville (1979: 33).

21 For a useful discussion of multiple or uncertain identity, see Derrida (1996).

22 Grand suggests that it was accent which marked out the immigrant Jews:

A dubious accent which is hard to place, which betrays the speaker's dodgy origins. That accent which a whole generation of Jews arriving in France in the 1920s, exuding hope from every pore, dragged with them, that Yiddish tone which was a dead give-away with every syllable they uttered, made them vulnerable.

(1996: 17)

23 Jacobson's sister notes that their mother was unable to communicate with her family during her imprisonment prior to deportation as she could not write French, and letters in Russian were forbidden by the authorities (1997: 84).

24 Chirac's predecessor, Mitterrand, had sought to emphasise the distinction between France and Vichy in a speech of 14 July 1992: 'The Republic has always sought to avoid racial segregation. Let us then not call the Republic to account! But in 1940 there was a "French state", it was the Vichy regime, it was not the Republic', cited in Conan and Rousso (1996: $60)$.

25 See Sartre on the attitude of the anti-Semite and the democrat towards the Jew:

The former seeks to destroy him as a man so that only the Jew, the pariah, the untouchable remains of him; the latter wants to destroy him as a Jew in order to preserve only the man, the abstract universal subject of the rights of man and of the citizen.

(1946: 68)

26 The concept of the Jews as a 'nation within a nation' is perhaps most famously associated with Clermont-Tonnerre arguing for the emancipation of the Jews in the French Constituent Assembly: 'One must refuse everything to the Jews as a Nation, and give everything to the Jews as individuals' cited in P. Birnbaum (1995: 22). Finkilkraut paraphrases antiSemitic articulations of the same phrase: 'These people who envisage paying taxes to a foreign power while flaunting their excessive feeling of community - are they truly citizens of France? Pride of caste and dual allegiance makes them a nation within a nation' (1994: 57). 


\section{Notes}

\section{Conclusion: the case of Charlotte Delbo}

1 See for example: Thatcher's monograph (2000) and articles and chapters by Bracher (1992a: 252-62; 1992b: 255-72; 1994: 81-93); Hamaoui (1991: 243-59); Kincaid (1984: 98-109); Lamont (1975: 1-17; 1979: 65-74; 1988: 247-52); Langer (1978: 201-52; 1994: 64-71); Prévost (1965: 41-4); Rothberg (2000: 141-77); Schumacher (1995: 155-63); Tolansky and Thatcher (1997: 59-72).

2 Henceforth referred to as 'A', 'C', and ' $M$ ' respectively. Reference is also made to La Mémoire et les jours (1985, henceforth MJ), and Spectres, mes compagnons (1995, first published 1977, henceforth S). Translations of the trilogy are taken from R. C. Lamont (1995); translations of La Mémoire et les jours and Spectres, mes compagnons are my own.

3 See Thatcher (2000: 24-6).

4 Delbo was the secretary of actor and theatre director Louis Jouvet from $1937-41$.

5 The section narrated by 'Ida' echoes much of the material found in Ida Grinspan's J'ai pas pleuré (2002). Delbo also gives her narration over to a range of first-person narrators - Jews and non-Jews, male and female, of various nationalities - in her posthumous La Mémoire et les jours (1985).

6 For a useful discussion of the role of the reader in Delbo's work, see Bracher (1994: 81-93).

7 These opening pages (M: 9-18) are repeated with minor modifications in Spectres, mes compagnons (1995: 41-8).

8 Delbo takes up and explores the meaning of the two terms 'vrai' and 'véridique' in La Mémoire et les jours (11-14). For a discussion of these terms, see Thatcher (2000: 30-5).

9 The chronology can only be described as 'loose': Une Connaissance inutile, for instance, opens with a return to Delbo's imprisonment prior to deportation. 


\section{Bibliography}

\section{Primary sources: testimonial accounts}

All texts are published in Paris unless stated otherwise.

Abadi, Odette (1995) Terre de détresse: Birkenau, Bergen-Belsen, L'Harmattan. Alcan, Louise (1947) Sans armes et sans bagages, Limoges: Les Imprimés d'art.

- (1980) Le Temps écartelé, L. Alcan.

Alizon, Simone (1996) L'Exercice de vivre, Stock.

Améry, Odette and Martin-Champier, G. (1945) Nuit et brouillard, Éditions Berger-Levrault.

Ammar, Catherine (1970) La Douceur de revivre, Éditions Dumas.

Asseo, Estréa Zaharia (1974) Les Souvenirs d'une rescapée, La Pensée universelle.

Aylmer-Roubenne, Madeleine (1996) J'ai donné la vie dans un camp de la mort, J.-C. Lattès.

Bauer, Anne-Marie (1993) Les oubliés et les ignorés, Mercure de France.

Benoist-Lucy, Chantal (1994) Sortie de l'Abîme, 1942-1945, ARHIS.

Birnbaum, Suzanne (1946) Une Française juive est revenue, Éditions du Livre français.

Blanc, Solange (1984) Femmes à tuer, La Pensée universelle.

Bloch, Claudette (ed.) (1946) Témoignages sur Auschwitz, Amicale des Déportés d'Auschwitz.

Bouteille-Garagnon, Marie-Jeanne (1946) Infernal rébus, Moulins: Crépin Leblond.

- (1948) Carrefour en Bobème, Vichy: B.-Garagnon.

Brun, Jackye (1979) Jusqu'au rivage des morts, La Pensée universelle.

Busson, Suzanne (1946) Dans les griffes nazies, Le Mans: Éditions Pierre Belon. Chombart de Lauwe, Marie-José (1998) Toute une vie de résistance, Graphein FNDIRP.

Christophe, Francine (1996) Une petite fille privilégiée, L'Harmattan.

Christophe, Marcelle (1995) Une Famille dans la guerre: 1940-1945, L'Harmattan; first published 1974 as Le Miracle de nos prisons: 1940-1945, Presses de la Cité. 


\section{Bibliography}

Corblet de Fallerans, Monique (1992) Voyage nocturne au bout du parc: d'Audrieu à Ravensbrück, Saint-Martin-des-Entrées: Éditions Heimdal.

Crémieux, Rosine (1999) La Traîne-sauvage, Flammarion.

Crisimily, Émilie (1981) Traumatisme psychique, La Pensée universelle.

Cynamon-Goldenberg, Sylvie (2002) Ça va aller, Rennes: La Part commune.

Davidovici, Édith (1998) Vivre après la Shoab, E. Davidovici.

Delbo, Charlotte (1965) Le Convoi du 24 janvier, Minuit.

-(1970a) Aucun de nous ne reviendra, Minuit; first published 1965, Gonthier.

- (1970b) Une Connaissance inutile, Minuit.

-(1971) Mesure de nos jours, Minuit.

-(1995a) Spectres, mes compagnons, Berg International; first published 1977, Lausanne: Maurice Bridel.

—(1995b) La Mémoire et les jours, Berg International; first published 1985, Berg International.

de Loulay, Wanda-Andrée Carliez-Lambert (1945) Déportée 50.440, Éditions André Bonne.

Douhéret, Léa (1993) Témoignage, Cavaillon: L. Douhéret.

Dufournier, Denise (1945) La Maison des mortes: Ravensbrück, Hachette; 2nd edn. 1992, Julliard.

Du Fresnes, Madeleine (1947) De l'enfer des bommes à la cité de Dieu, Éditions Spes.

Elina, Odette (1982) Sans fleurs ni couronnes, Le Cannet: O. Elina.

Fabius, Odette (1986) Un lever de soleil sur le Mecklembourg, Albin Michel.

Felloni, Madeleine (1946) Voyage en enfer, Châlons-sur-Marne: M. Felloni

Fénelon, Fania (1976) Sursis pour l'orchestre, Stock.

Friang, Brigitte (1997) Regarde-toi qui meurs, Éditions du Félin; first published 1970, R. Laffont.

Gaulle-Anthonioz, Geneviève de (1998) La Traversée de la nuit, Seuil.

Gorce, Nelly (1995) Journal de Ravensbrück, Arles: Actes Sud.

Grand, Odile (1996) Couleur citron, côté cceur, Hachette.

Grinspan, Ida and Poirot-Delpech, B. (2002) J'ai pas pleuré, Robert Laffont.

Guillemin-Ducret, Denise (1986) Matricule 19374, afin que nul n'oublie, La Grande Motte: D. Guillemin-Ducret.

Guillerme, Marc le (pseudonym) (1946) Hors la vie: journal d'une déportée, Fasquelle.

Guyon-Belot, Raymonde (1990) Le Sel de la mine, Éditions France-Empire.

Hautval, Adélaïde (1991) Médecine et crimes contre l'bumanité, Actes Sud.

Heftler, Nadine (1992) Si tu t'en sors, Éditions La Découverte.

Hollander-Lafon, Magda (1977) Les Chemins du temps, Éditions ouvrières.

Holstein, Denise (1995) 'Je ne vous oublierai jamais, mes enfants d'Auschwitz...', Éditions ${ }^{\circ} 1$

Huk, Cécile (1958) Et le Ciel resta bleu, Éditions du Scorpion.

Jacobson, Louise (1997) Les Lettres de Louise Jacobson et de ses proches, Robert Laffont. 
Jeannin-Garreau, Éliane (1991) Ombre parmi les ombres: cbronique d'une Résistance, Issy-les-Moulineaux: Muller.

-1994) Les Cris de la mémoire: Ravensbrück-Holleischen, 1943-45, Issy-lesMoulineaux: E. Jeannin-Garreau.

Lagrange, Simone (1997) Coupable d'être née: adolescente à Auschwitz, L'Harmattan. Lahaye, Simone (1954) 'Visions d'un camp de concentration', L'Année politique et économique, 115-16, 120 (December 1953-August 1954).

-(1963) Les Rachetées: portraits et récits de bagne, G. Durassié \& Cie.

-1983) Libre parmi les morts: Ravensbrïck 1942-45, Berg International.

Lasnet de Lanty, Henriette (1965) Sous la schlague, Bergerac: H. Triffaud \& Cie.

Lesèvre, Lise (1987) Face à Barbie: souvenirs-cauchemars, de Montluc à Ravensbrück, Les Nouvelles éditions du Pavillon.

Lévy-Osbert, Liliane (1992) Jeunesse vers l'abîme, Études et documentation internationales.

London, Lise (1995) La Mégère de la rue Daguerre, Seuil-Mémoire.

Lorge, Jehanne (1992) Déportée pour une injure, Saint-Claude: Raymond Vaudey.

Louria, Renée (1979) Les Russes sont à Lemberg, Gallimard.

Mallet, Mireille (1949) Sous le signe du triangle, Dijon: Imprimerie Jobard.

Maous, Françoise (1996) Coma: Auschwitz no. A5553, Geneva: Comptoir.

Marette, Fanny (1954) J'étais le numéro 47.177, F. Marette.

Marmor, Tosca (1990) Le Piano rouge, Fayard.

Matricule 55310 (1945) Birkenau: bagne de femmes, Fernand Nathan.

Maurel, Micheline (1957) Un Camp très ordinaire, Minuit.

Maurice, Violette (1946) N.N., Saint-Étienne: SPER; subsequent editions 1991 and 1995 Encre Marine.

-(1990) Les murs éclatés, Saint-Étienne: Action Graphique.

-1993) Résurgences, Saint-Étienne: Action Graphique.

Mirande-Thomas, Renée (1945) De Ravensbrïck à Mautbausen, Éditions de la Défense.

Mori-Perrin, Josette de (1992) Pour que demain soit liberté, Autun: Imprimerie Pelux.

Novac, Ana (1996) Les beaux jours de ma jeunesse, Julliard 1968; subsequent edition 1996 Balland.

Ourisson, Douria (1947) Les Secrets du bureau politique d'Auschwitz, Amicale des Déportés d'Auschwitz.

Pagniez, Yvonne (1947) Scènes de la vie de bagne, Flammarion.

-(1949) Evasion 1944, Flammarion.

-(1950) Ils resusciteront d'entre les morts, Flammarion.

Paul, Sylvie (1962) Ne me jugez pas, Gallimard.

Picard, Juliane (1995) Des ténèbres à la lumière, Éditions Eska.

Renault, Maisie (1948) La Grande Misère, Éditions Chavanne.

Rothman-Le Dret, Catherine (1994) L'Amérique déportée: Virginia d'Albert Lake, de la Résistance à Ravensbrück, Nancy: Presses Universitaires de Nancy. 


\section{Bibliography}

Roux, Catherine (1946) Triangle rouge, Lyon: H. Audin.

Saint-Clair, Simone (1945) Ravensbrück: l'enfer des femmes, Jules Tallandier; 2nd edn. 1966, Fayard.

Schapira, Charlotte (1994) Il faudra que me souvienne: la déportation des enfants de l'Union Générale des Israélites de France, L'Harmattan.

Serre, Charlotte (1982) De Fresnes à Ravensbrück, Guilde des lettres.

Simier, Lucienne (1992) 2 ans de bagne de Ravensbrück, Maulévrier: Hérault.

Simone, la capitaine (pseudonym of Anne-Marguerite Dumilieu) (1975) Moi, un cobaye, SEFA.

Tichauer, Eva (1988) J'étais le numéro 20932 à Auschwitz, L'Harmattan.

Tillion, Germaine (1997) La Traversée du mal, Arlea.

Touboul, Camille (1982) Un Relais d'étoiles: souvenirs d'Auschwitz, Montréal: Productions Julad; 2nd edn. 1997 as Le plus long des chemins: de Marseille à Auschwitz, Nice: Editions du Losange.

Toulouse-Lautrec, Béatrix (1967) La Victoire en pleurant, Rouen: Editions de la Préfecture; 2nd edn. 1981, Éditions France-Empire.

Tubeuf-Branchu, Yvonne (1962) Récit de ma déportation, 1942-1945, ElbeufParis: Duval.

Vaillant-Couturier, Marie-Claude (1946) Mes vingt-sept mois entre Auschwitz et Ravensbrück, Éditions du Mail.

Valois, Eugénie (1969) Ceux qui n'ont pas eu vingt ans, Debresse.

Wilborts, Suzanne (1946) Pour la France: La Santé, Fresnes, Ravensbrück, Mauthaussen, Charles Lavauzelle.

\section{Secondary sources}

Amicale de Ravensbrück et Association des Déportées et Internées de la Résistance (1965) Les Françaises à Ravensbrück, Paris: Gallimard.

Anderson, B. (1991) Imagined Communities, London: Verso.

Ascheron, N. (1987) The Struggles for Poland, London: Michael Joseph.

Azéma, J.-P. and Bédarida, F. (eds) (1993) La France des années noires, Paris: Seuil.

Bartov, O. (1993) 'Intellectuals on Auschwitz: memory, history and truth', History and Memory: Studies in Representations of the Past, 5(1): 87-129.

Baskin, J. (ed.) (1994) Women of the Word: Jewish Women and Jewish Writing, Detroit: Wayne State University Press.

Bédarida, F. and Gervereau, L. (eds) (1995) La Déportation et le système concentrationnaire, Paris: Collection des publications de la BDIC.

Bendremer, J. T. (1997) Women Surviving the Holocaust, Lewiston: Edwin Mellen Press.

Bertin, C. (1993) Femmes sous l'Occupation, Paris: Éditions Stock.

Beverley, J. (1996) 'The margin at the centre: on testimonio', in G. M. Gugelberger (ed.) The Real Thing: Testimonial Discourse and Latin America, Durham, NC: Duke University Press. 
Birnbaum, P. (1995) Destins juifs: de la Révolution française à Carpentras, Paris: Calmann-Lévy.

Bitoux, J. le (2002) Les Oubliés de la mémoire, Paris: Hachette Littératures.

Boisson, J. (1988) Le Triangle rose: la déportation des bomosexuels, 1933-1945, Paris: R. Laffont.

Bornand, M. (1997) 'Pour une écriture de l'exil: Charlotte Delbo, Jean Améry, Agota Kristof, Antoine Volodine', Actes du deuxième Colloque de la Relève Suisse en Études Littéraires, Geneva, 6-7 June.

Bracher, N. (1992a) 'Faces d'histoire, figures de violence: métaphore et métonymie chez Charlotte Delbo', Zeitschrift fur Franzosische Sprache und Literatur, 102(3): 252-62.

- (1992b) 'Humanisme, violence et métaphysique: la thématique du visage chez Charlotte Delbo', Symposium: A Quarterly Journal in Modern Literatures, 45(4): 255-72.

- (1994) 'Histoire, ironie et interprétation chez Charlotte Delbo: une écriture d'Auschwitz', French Forum, 19(1): 81-93.

Brah, A. et al. (1999) Thinking Identities: Ethnicity, Racism and Culture, New York: Macmillan Press.

Braham, R. (ed.) (1990) Reflections of the Holocaust in Art and Literature, Boulder, CO: Social Science Monographs.

Brenner, R. F. (1997) Writing as Resistance: Four Women Confronting the Holocaust, University Park, PA: Pennsylvania State University Press.

Bridenthal, R. et al. (eds) (1984) When Biology Became Destiny: Women in Weimar and Nazi Germany, New York: Monthly Review Press.

Camus, A. (1972) Lettres à un ami allemand, Paris: Gallimard; first published 1948, Gallimard.

Caron, V. (1999) Uneasy Asylum: France and the Jewish Refugee Crisis, 1933-1942, Stanford, CA: Stanford University Press.

Caruth, C. (1995) Trauma: Explorations in Memory, Baltimore, MD: Johns Hopkins University Press.

-(1996) Unclaimed Experience: Trauma, Narrative and History, Baltimore, MD: Johns Hopkins University Press.

Cayrol, J. (1953) 'Témoignage et littérature', Esprit, April: 575-8.

Conan, E. and Rousso, H. (1996) Vichy: un passé qui ne passe pas, Paris: Gallimard; first published 1994, Fayard.

Copley, A. (1989) Sexual Moralities in France 1780-1980, London: Routledge.

Crowley, M. (2003) Robert Antelme: Humanity, Community, Testimony, Oxford: Legenda.

Davies, N. (1981) God's Playground: A History of Poland, vol. II: 1795 to the Present, Oxford: Clarendon Press.

Derrida, J. (1996) Le Monologuisme de l'autre, Paris: Éditions Galilée.

Des Près, T. (1980) The Survivor: An Anatomy of Life in the Death Camps, Oxford: Oxford University Press.

Duchen, C. (1994) Women's Rights and Women's Lives in France 1944-1968, London: Routledge. 


\section{Bibliography}

Dulong, R. (1998) Le Témoin oculaire, Paris: École des Hautes Études en Sciences Sociales.

Eaglestone, R. (2000) 'From behind the bars of quotation marks: Emmanuel Levinas's (non)-representation of the Holocaust', in A. Leak and G. Paizis (eds) The Holocaust and the Text, Basingstoke: Macmillan.

-(2001) Postmodernism and Holocaust Denial, Cambridge: Icon Books.

Elman, R. A. (1999) 'Lesbians and the Holocaust', in E. Fuchs (ed.) Women and the Holocaust, Lanham, MD: University Press of America.

Evans, R. (1997) In Defence of History, London: Granta Books.

-(2002) Telling Lies about Hitler, London: Verso.

Ezrahi, S. D. (1980) By Words Alone: The Holocaust in Literature, Chicago: University of Chicago Press.

-(1996) 'Representing Auschwitz', History and Memory, 7(2): 121-54.

Felman, S. and Laub, D. (1992) Testimony: Crises of Witnessing in Literature, Psychoanalysis and History, New York: Routledge.

Fine, E. (1990) 'Women writers and the Holocaust: Strategies for survival', in R. Braham (ed.) Reflections of the Holocaust in Art and Literature, Boulder, CO: Social Science Monographs.

Finkielkraut, A. (1994) The Imaginary Jew (trans. K. O'Neill and D. Suchoff), Lincoln, NE: University of Nebraska Press; first published 1980 as Le Juif imaginaire, Paris: Seuil.

Finney, P. (1998) 'Ethics, historical relativism and Holocaust denial', Retbinking History, 2: 359-69.

Foley, B. (1982) 'Fact, fiction, fascism: testimony and mimesis in Holocaust narratives', Comparative Literature, 34(4): 330-60.

Friedlander, J. (1995) 'Anti-Semitism in France, 1978-1992', in L. D. Kritzman (ed.) Auschwitz and After: Race, Culture and 'the Jewish Question' in France, London: Routledge.

Friedlander, S. (1994) 'Trauma, memory and transference', in G. H. Hartman (ed.) Holocaust Remembrance: The Shapes of Memory, Oxford: Blackwell.

- (1997) 'Probing the limits of representation', in K. Jenkins (ed.) The Postmodern History Reader, London: Routledge.

Fuchs, E. (1999) Women and the Holocaust: Narrative and Representation, Lanham, MD: University Press of America.

Gilbert, M. (1987) The Holocaust, London: Collins.

Gildea, R. (1996) France since 1945, Oxford: Oxford University Press.

-(2002) Marianne in Chains: In Search of the German Occupation 1940-45, Basingstoke: Macmillan.

Goldenberg, M. (1990) 'Different horrors, same hell', in R. Gottlieb (ed.) Thinking the Untbinkable: Meanings of the Holocaust, New York: Paulist Press.

- (1998) 'Memoirs of Auschwitz survivors: the burden of gender', in D. Ofer and L. J. Weitzman (eds) Women in the Holocaust, New Haven, CT: Yale University Press. 
Gottlieb, R. (ed.) (1990) Thinking the Untbinkable: Meanings of the Holocaust, New York: Paulist Press.

Grau, G. (1995) Hidden Holocaust? Gay and Lesbian Persecutions in Germany 1933-1945, New York: Cassell.

Grierson, K. (1999) “Vérité”, littérature et vraisemblance dans le récit de déportation', in A. Wieviorka and C. Mouchard (eds) La Shoab: témoignages, savoirs, cuvres, Vincennes: Presses universitaires de Vincennes.

Gugelberger, G. M. (ed.) (1996) The Real Thing: Testimonial Discourse and Latin America, Durham, NC: Duke University Press.

Guidez, G. (1989) Femmes dans la guerre 1939-1945, Paris: Perrin.

Gutman, Y. and Berenbaum, M. (eds) (1998) Anatomy of Auschwitz Death Camp, Bloomington, IN: Indiana University Press.

Haffner, D. (1946) Aspects pathologiques du camp de concentration d'AuschwitzBirkenau, Tours: Imprimerie de l'Union coopérative.

Hamaoui, L. F. (1991) 'Art and testimony: the representation of historical horror in literary works by Piotr Rawicz and Charlotte Delbo', Cardozo Studies in Law and Literature, 3(2): 243-59.

Hardman, A. (2000) Women and the Holocaust, London: Holocaust Educational Trust.

Hartman, G. H. (1993) 'Public memory and modern experience', Yale Journal of Criticism, 6(2): 239-47.

-(ed.) (1994) Holocaust Remembrance: The Shapes of Memory, Oxford: Blackwell.

-(1996) The Longest Shadow: In the Aftermath of the Holocaust, Bloomington, IN: Indiana University Press.

Heinemann, M. (1986) Gender and Destiny: Women Writers and the Holocaust, Westport, CT: Greenwood Press.

Hoess, R. (2000) Commandant of Auschwitz (trans. C. FitzGibbon), London: Phoenix Press; first published as Wspomnienia 1951, Warsaw: Wydawnictwo Prawnicze.

Horowitz, S. R. (1992) 'Rethinking Holocaust testimony: the making and unmaking of the witness', Cardozo Studies in Law and Literature, 4(1): 45-68.

- (1994) 'Memory and testimony of women survivors of Nazi genocide', in J. Baskin (ed.) Women of the Word: Jewish Women and Jewish Writing, Detroit: Wayne State University Press.

- (1998) 'Women and the Holocaust: engendering trauma memory', in D. Ofer and L. J. Weitzman (eds) Women in the Holocaust, New Haven, CT: Yale University Press.

Hugounenq, S. (1981) 'La chambre à gaz de Ravensbrück', Voix et Visages, 176: 1 .

Jackson, J. (2001) France: The Dark Years 1940-1944, Oxford: Oxford University Press.

Jenkins, K. (1991) Re-Thinking History, London: Routledge.

- (1995) On 'What is History'? From Carr and Elton to Rorty and White, London: Routledge. 


\section{Bibliography}

-(ed.) (1997) The Postmodern History Reader, London: Routledge.

- (1999) Why History? Etbics and Postmodernity, London: Routledge.

Karay, F. (1998) 'Women in forced-labor camps', in D. Ofer and L. J. Weitzman (eds) Women in the Holocaust, New Haven, CT: Yale University Press.

Kessel, J. (1963) L'Armée des ombres, Paris: Pocket.

Kincaid, R. A. (1984) 'Charlotte Delbo's Auschwitz et après: the struggle for signification', French Forum, 9(1): 98-109.

Klarsfeld, S. (1978) Le Mémorial de la déportation des Juifs de France, New York: Beate Klarsfeld Foundation.

Koos, C. (1999) 'On les aura!: The gendered politics of abortion and the Alliance Nationale contre la Dépopulation, 1938-1944', Modern and Contemporary France, 7(1): 21-33.

Kritzman, L. D. (ed.) (1994) Auschwitz and After: Race, Culture, and 'the Jewish Question' in France, New York: Routledge.

Kubica, H. (1998) 'Children', in Y. Gutman and M. Berenbaum (eds) Anatomy of Auschwitz Death Camp, Bloomington: Indiana University Press.

LaCapra, D. (1994) History, Theory, Trauma: Representing the Holocaust, Ithaca, NY: Cornell University Press.

-1998) History and Memory after Auschwitz, Ithaca, NY: Cornell University Press.

Lamont, R. C. (1975) 'Literature, the exile's agent of survival: Alexander Solzhenitsyn and Charlotte Delbo', Mosaic: A Journal for the Interdisciplinary Study of Literature, 9(1): 1-17.

- (1979) 'Charlotte Delbo's frozen friezes', Esprit créateur, 19(2): 65-74.

- (1988) 'Charlotte Delbo, a woman/book', in A. Kessler-Harris and W. McBrien (eds) Faith of a (Woman) Writer, Westport, CT: Greenwood Press.

-(1995) Auschwitz and After: Charlotte Delbo, New Haven, CT: Yale University Press.

Lang, B. (1997) 'Is it possible to misrepresent the Holocaust?', in K. Jenkins (ed.) The Postmodern History Reader, London: Routledge.

-(2000) 'Holocaust genres and the turn to history', in A. Leak and G. Paizis (eds) The Holocaust and the Text, Basingstoke: Macmillan.

Langbein, H. (1998) 'The Auschwitz underground', in Y. Gutman and M. Berenbaum (eds) Anatomy of Auschwitz Death Camp, Bloomington: Indiana University Press.

Langer, L. L. (1978) The Age of Atrocity: Death in Modern Literature, Boston: Beacon.

-1982) Versions of Survival: The Holocaust and the Human Spirit, Albany, NY: State University of New York Press.

-1991) Holocaust Testimonies: The Ruins of Memory, New Haven, CT: Yale University Press.

- (1994) 'From sight to insight: the legacy of Charlotte Delbo', Contemporary French Civilization, 18(1): 64-71. 
-(1998) 'Gendered suffering? Women in Holocaust testimonies', in D. Ofer and L. J. Weitzman (eds) Women in the Holocaust, New Haven, CT: Yale University Press.

Laska, V. (ed.) (1983) Women in the Resistance and in the Holocaust, Westport, CT: Greenwood Press.

- (1993) 'Women in the Resistance and in the Holocaust', in C. Rittner and J. Roth (eds) Different Voices, New York: Paragon House.

Leak, A. and Paizis, G. (eds) (2000) The Holocaust and the Text, Basingstoke: Macmillan.

Lesselier, C. (1993) 'Silenced resistance and conflictual identities: lesbians in France 1930-68', Journal of Homosexuality, 25: 105-25.

Levi, P. (1987) If This is a Man, London: Abacus.

Lewinska, P. (1945) Vingt mois à Auschwitz, Paris: Nagel.

Lifton, J. and Hacket, A. (1998) 'Nazi doctors', in Y. Gutman and M. Berenbaum (eds) Anatomy of Auschwitz Death Camp, Bloomington: Indiana University Press.

Lifton, R. J. (1986) The Nazi Doctors, London: Macmillan.

Lipstadt, D. (1993) Denying the Holocaust: The Growing Assault on Truth and Memory, New York: Free Press.

Maechler, S. (2000) The Wilkomirski Affair: A Study in Biographical Truth (trans. J. E. Woods), New York: Schocken Books; first published 2000 as Der Fall Wilkormiski, Zurich: Pendo Verlag.

Marrus, M. and Paxton, R. O. (1981) Vichy et les Juifs (trans. M. Delmotte), Paris: Calmann-Lévy.

Ministry of Justice, State of Israel (1992-4) The Trial of Adolf Eichmann: A Record of the Proceedings of the District Court of Jerusalem, 6 vols, Jerusalem: Ministry of Justice.

Morrison, J. G. (2000) Ravensbrück, Princeton, NJ: Markus Wiener Publishers.

Muel-Dreyfus, F. (1996) Vichy et l'éternel féminin, Paris: Seuil.

Munslow, A. (1997) Deconstructing History, London: Routledge.

Novick, Peter (2000) The Holocaust and Collective Memory: The American Experience, London: Bloomsbury.

Ofer, D. and Weitzman, L. J. (eds) (1998) Women in the Holocaust, New Haven, CT: Yale University Press.

Owings, A. (1993) Frauen: German Women Recall the Third Reich, London: Penguin.

Parrau, A. (1995) Écrire les camps, Paris: Éditions Belin.

Piper, F. (1998) 'Gas chambers and crematoria', in Y. Gutman and M. Berenbaum (eds) Anatomy of Auschwitz Death Camp, Bloomington: Indiana University Press.

Plant, R. (1986) The Pink Triangle: The Nazi War against Homosexuals, New York: Henry Holt and Co.

Pollak, M. (1990) L'Expérience concentrationnaire: essai sur le maintien de l'identité sociale, Paris: Métailié. 


\section{Bibliography}

Pollard, M. (1998) Reign of Virtue: Mobilising Gender in Vichy France, Chicago: University of Chicago Press.

Posadskaya, A. (ed.) (1994) Women in Russia, London: Verso.

Pressac, J.-C. and Van Pelt, R.-J. (1998) 'The machinery of mass murder at Auschwitz', in Y. Gutman and M. Berenbaum (eds) Anatomy of Auscbwitz Death Camp, Bloomington, IN: Indiana University Press.

Prévost, C. (1965) 'Entretien avec Charlotte Delbo: la Déportation dans la littérature et l'art', La Nouvelle Critique, 167(June): 41-4.

Reiter, A. (1989) "'Brot war eine feste Insel in dem Wassersuppenmeer ...": Literary imagination as a means of survival, as reflected in concentrationcamp reports', Forum for Modern Language Studies, 25(2): 123-38.

- (1991) 'Literature and survival: the relationship between fact and fiction in concentration camp memoirs', Journal of European Studies, 21: 259-79.

- (1995) 'Narrating the Holocaust: communicating the end or the end of communication?', Patterns of Prejudice, 29: 75-87.

-(2000) Narrating the Holocaust, London: Continuum.

Ricœur, P. (2000) La Mémoire, l'bistoire, l'oubli, Paris: Seuil.

Ringelheim, J. (1984) 'The unethical and the unspeakable: women and the Holocaust', Simon Wiesenthal Centre Annual, 1: 69-87.

- (1985) 'Women and the Holocaust: a reconsideration of research', Signs, 10(4): 741-61; republished 1993 in C. Rittner and J. Roth (eds) Different Voices: Women and the Holocaust, New York: Paragon House.

Rittner, C. and Roth, J. (1993) Different Voices: Women and the Holocaust, New York: Paragon House.

Rothberg, M. (2000) Traumatic Realism: The Demands of Holocaust Representation, Minneapolis: University of Minnesota Press.

Rousso, H. (1990) Le Syndrome de Vichy, Paris: Seuil.

Sartre, J.-P. (1946) Réflexions sur la question juive, Paris: Gallimard.

Sautman, F. C. (1990) 'Invisible women: lesbian working-class culture in France, 1880-1930', in J. Merrick and B. Ragan Jr. Homosexuality in Modern France, New York: Oxford University Press.

Schoppman, C. (1996) Days of Masquerade: Life Stories of Lesbians during the Third Reich, New York: Columbia University Press.

Schumacher, C. (1995) 'Charlotte Delbo: le théâtre comme moyen de survie', Créer pour surviure (Actes du Colloque International de l'Université de Reims), Paris: Fédération des Déportés, Internés, Résistants et Patriotes.

Semprun, J. (1994) L'Ecriture ou la vie, Paris: Gallimard.

Silverman, M. and Yuval Davis, N. (1999) 'Jews, Arabs and the theorisation of racism in Britain and France', in A. Brah et al. Thinking Identities: Ethnicity, Racism and Culture, New York: Macmillan Press.

Sofsky, W. (1997) The Order of Terror: The Concentration Camp (trans. W. Templer), Princeton, NJ: Princeton University Press; first published 1993 as Die Ordnung des Terrors: Das Konzentrationslager, Frankfurt am Main: Fischer. 
Strzelecka, I. (1998) 'Women', in Y. Gutman and M. Berenbaum (eds) Anatomy of Auschwitz Death Camp, Bloomington: Indiana University Press.

Subiotto, A. (1991) 'Dante and the Holocaust: the cases of Primo Levi and Peter Weiss', New Comparison, 11: 70-89.

Thatcher, N. (2000) A Literary Analysis of Charlotte Delbo's Concentration Camp Re-Presentation, Lampeter: Edwin Mellen Press.

Tillion, G. (1988) Ravensbrück, Paris: Seuil.

Todorov, T. (1998) Les Abus de la mémoire, Paris: Arléa.

-(2000) Facing the Extreme: Moral Life in the Concentration Camps (trans. A. Denner and A. Pollack), London: Phoenix, first published 1991 as Face à l'extrême, Paris: Seuil.

Tolansky, E. and Thatcher, N. (1997) 'Testimony and vision: poetic responses to concentration camp experience', Romance Studies, 30: 59-72.

Truck, Betty (1975) Médecins de la bonte, Paris: Presses de la Cité.

- (1976) Mengele, ange de la mort, Paris: Presses de la Cité.

Vaillant-Couturier, M.-C. (1946) Marie-Claude Vaillant-Couturier accuse ...: sa déposition au procès de Nuremberg, Paris: L'Union des femmes français

Virgili, F. (2002) Shorn Women: Gender and Punishment in Liberation France (trans. J. Flower), Oxford: Berg; first published 2000 as La France 'virile': des femmes tondues à la libération, Paris: Payot.

White, H. (1997) 'Historical emplotment and the problem of the truth', in K. Jenkins (ed.) The Postmodern History Reader, London: Routledge.

Wieviorka, A. (1989) 'Indicible ou inaudible? La Déportation: premiers récits (1944-47)', Pardès, 9-10: 23-59.

- (1992) Déportation et génocide, Paris: Plon.

- (1994a) 'Rendez-vous à l'Hôtel Lutécia', L'Histoire, 179: 76-77.

- (1994b) 'On testimony', in G. H. Hartman (ed.) Holocaust Remembrance: The Shapes of Memory, Oxford: Blackwell.

-(1998) L'Ère du témoin, Paris: Plon.

Wieviorka, A. and Mouchard, C. (eds) (1999) La Shoab: témoignages, savoirs, auvres, Paris: Presses universitaires de Vincennes.

Wilkomirski, B. (1996) Fragments: Memories of a Childhood, 1939-1948 (trans. C. B. Janeway), New York: Schocken; first published 1995 as Brucbstücke: aus einer Kindheit 1939-1948, Frankfurt am Main: Jeudischer Verlag.

Yerushalmi, Y. (1982) Zakbor: Jewish History and Jewish Memory, Seattle: University of Washington Press.

Young, J. E. (1987a) 'Modern Jewish culture', Contemporary Literature, 28(2): 278-83.

-(1987b) 'Interpreting literary testimony: a preface to rereading Holocaust diaries and memoirs', New Literary History, 18(2): 403-23.

-(1988) Writing and Rewriting the Holocaust: Narrative and the Consequences of Interpretation, Bloomington, IN: Indiana University Press.

Yúdice, George (1996) 'Testimonio and postmodernism', in G. M. Gugelberger (ed.) The Real Thing: Testimonial Discourse and Latin America, Durham, NC: Duke University Press. 


\section{Bibliography}

Zamoyski, A. (1987) The Polish Way: A Thousand-Year History of the Poles and their Culture, New York: Hippocrene Books.

Zhuk, O. (1994) 'The lesbian subculture: the historical roots of lesbianism in the former USSR', in A. Posadskaya (ed.) Women in Russia, London: Verso.

Zuccotti, S. (1993) The Holocaust, the French, and the Jews, New York: Basic Books. 


\section{Index}

Abadi, Odette: Terre de détresse 39-40, 49, 54, 57, 67-8, 83, 86-7, 92, 94, 96, $98,119,138-9,153,155,156,164$, $165,170,176,178,180,181,184$

abortion, see female body abuse, sexual 104; Allied 109-10; Nazi 109; Russian 109-10

affective response 13

Aix-la-Chapelle 23

Alcan, Louise 176, 181, 184, 185, 195; Sans armes et sans bagages $58,59,60$, $97-8,112,127,148,165-6,187$, 194; Le Temps écartelé 21, 34, 53, 65-6, $111,113,194$

alcohol 106

Alizon, Simone: L'Exercice de vivre 14, 67, $166,172,185,188$

allusions 88-99

amendments 40-2, 61-2

amenorrhoea, see female body: menstruation

Améry, Jean 88

Améry, Odette: Nuit et brouillard 53, 56, $68,85,91,94,95,96,97,106,112$, $113,117,132,143,144,147,150$, $151,153,156,158-9,186,192$

Ammar, Catherine: La Douceur de revivre 53 Amstetten 23

anaphora 79

Anderson, Benedict: Imagined Communities 207-8

Angers 23

Angoulême 23

Antelme, Robert 2, 174, 212

anti-Semitism 97, 158, 169, 175, 215-16, 218; French 177-81, 187-92 apostrophe 78-84

appearance, see femininity

appendices 55-6

Apteroda 23, 110, 143

aptitude test 143

'Arbeit macht frei' 89

asocials, German 120, 145, 150-2

Asseo, Estréa Zaharia: Les Souvenirs d'une reschapée 53, 91, 176, 179-80, 185,

201, 203

Astérix et Obélix 95

Aubrac, Lucie and Raymond 1, 36

Audibert, General 44

Auschwitz-Birkenau: killing babies 137, 139; brothel 108; children in 180; clothing 131; 'ethnological survey' 194; evacuation of 65 ; executions 129; gas chambers 41,183 ; Jews in 2, 149, 181, 216; marshes drained 106; medical experiments 55 ; numbers 153; orchestra $37,118,122,132$, 165,198 ; prisoners run for their life 212-13; Ravensbrück compared with 182-7; Sonderkommando 187; Union arms factory 124,129 ; young people visit 65-6

authentification 80

Aylmer-Roubenne, Madeleine: J'ai donné la vie dans un camp de la mort 15,24 , $52,53,55,70,71,88,122,123$, $129,138,139,170$

Barbie, Klaus 16, 36, 128

Barth 23, 129, 147, 150

Bartov, Omer: 'Intellectuals on Auschwitz' 31 
Bauer, Anne-Marie: Les oubliés et les ignorés 55, 128

Bauer, Marie-Jeanne 172

Bédarida, F.: La Déportation 154

Behndorf 23, 144

Benoist-Lucy, Chantal: Sortie de l'Abîme 54, 56, 67, 122-3, 130, 143

Bergen-Belsen 92, 96, 111, 132, 138, 199, 205

Berlin 127

Bertin, Celia: Femmes sous l'Occupation 134

Besançon 23

Binz, Dorothea 89, 129

Birkenau, see Auschwitz-Birkenau

Birnbaum, Suzanne: Une Française juive est revenue $22,34,54,87,89,90,93$, $94,106,107,111,112,136,153$, $178,181,184,193-4$

black transports 182

Blanc, Solange: Femmes à tuer 10, 11, 53, $110,112,113,115,117,119$, 132-3, 139, 145, 157, 171, 190, 192

Blanchot 3

Bluette 41

BMW 143

body, see female body

Bonne cuisine quand même! 134

Bosnia 45

Bousquet, René 1, 36

Bouteille-Garagnon, Marie-Jeanne 3; Carrefour en Bobème 110, 113, 171; Infernal rébus 54, 144, 151, 155, 157, 162, 163, 170-1, 191

Brah, A.: Thinking Identities 206

bras, see feminity: clothing

Breughel, Peter 97

'Brigitte' 16

brothels 108

Brun, Jackye: Jusqu'au rivage des morts $17-18,46,54,57,75,79,80,82-3$, $89,94,95,96,105-6,114-15,120$, $121,125,126,135,138,144,150$, $156,161,168,174,186-7$

Buchenwald 174; brothel 108

Busson, Suzanne: Dans les griffes nazies $12,44,53,54,56,58,67,108-9$, $117,127,138,162$

Calley, William L. 211

Camus, Albert 25 cannibalism 42

Catholic League of French Women 167-8

Chaban-Delmas, Jacques 14, 55

Chambeiron, Robert 55

Chaplin, Charles: Les Temps modernes 97; The Great Dictator 97

Chirac, Jacques 1, 206

Chombart de Lauwe, Marie-José: Toute une vie de résistance $38,45,53,116$, 131, 157

Christophe, Francine: Une petite fille privilégiée 54, 83, 92, 95, 136, 139-40, 156, 176, 178-9, 180, 199-200

Christophe, Marcelle: Une Famille dans la guerre 123-4, 176

chronology 19, 57-8, 63-5

class $160-6$

Clauberg, Doctor 139

Clermont-Ferrand 23

clothing, see femininity

Cold War 28

collaborators 81

Cologne fortress 130

commemoration 48

Communists 104, 150, 167, 169-75, 216; Communist Youth 164; PCF 174

Compiègne 185

Conan, E.: Vichy 1, 26, 27, 206

Conche, Marcel 40, 55

'Concours de la Resistance' (1965) 66

Corblet de Fallerans, Monique: Voyage nocturne au bout du parc 111, 123, 125, $132,147,174,186$

corrections, see amendments

Courtois, Stéphane 55

'Coury', see Tillion, Germaine

credence 14-15; see also reception

Crémieux, Rosine: La Traîne-sauvage 16, 24-5, 38-9, 49, 53, 65-6, 94, 110, $143,156,164,176,181,195-7,212$

Crisimily, Émilie: Traumatisme psychique $46,51,124,143-4$

cross-references 33-5

Crowley, Martin: Robert Antelme 174, 212

Czechs 61, 145, 165

Dance of Death, The 96

Dante: Inferno 89, 90, 96 
Darquier de Pellepoix, Louis 30, 36, 46, 65

Davidovici, Édith: Viure après la Shoab 17, 45, 54, 137, 176, 180, 185, 203, 205

de Loulay, Wanda-Andrée CarliezLambert: Déportée 50.440 18, 52, 53, 72-3, 81, 86, 89, 90, 91, 94, 112, $119,125,127,128,161,162,163$, $168,183,191$

death march 185

defiance 142-5, 146

Delbo, Charlotte 2, 3, 4, 210-19; Aucun de nous ne reviendra 210, 215-16; Une connaissance inutile 210; Le Convoi du 24 janvier 210, 211; Le Mémoire et les jours 20, 21, 216; Mesure de nos jours 210, 211, 212, 216; Spectres, mes compagnons 214

Delétang, Camille 44

derealisation 25

Derrida, Jacques 3

dialogic text 65-6

diaries, see journals

'Didier' 16

Dijon 23

direct speech 73-8

Distel, Sacha 64

Douhéret, Léa: Témoignage 172-3

Drancy 2, 23, 123, 194, 195, 198, 199, 203; children in 180; Jews in 178

Du Fresnes, Madeleine: De l'enfer des bommes à la cité de Dieu 188

du Gard, Roger 25

Duchen, C.: Women's Rights and Women's Lives in France 140

Dufournier, Denise: La Maison des mortes (1945) 3, 40, 54, 68, 72, 75, 82, $87-8,89,116-17,163,(1992) 21-2$, $40-1,68,120$

Dulong, R.: Le Témoin oculaire 10, 12, 13 , $14,15,33,45$

Dumilieu, Anne-Marguerite, see 'Simone, la capitaine'

duty to the dead 47

Eaglestone, Robert: 'From behind the bars of quotation marks' 25

'Edek', see Galinski, Edward

education 43-4, 65-6

Eichmann, Adolf 12, 34, 36
El Greco 97

Elina, Odette: Sans fleurs ni couronnes 39, $56,92,97,139,163,176,184$

embedded documents 55-6

episodic structure 58

errors, factual $27-8,33-5$

ethnic cleansing 45

European Union 44

executions 128-9

L'Express 65

eye-witness accounts: status of 9-13

Ezrahi, S. D.: By Words Alone 76, 97;

'Representing Auschwitz' 89

Fabius, Odette: Un lever de soleil sur le Mecklembourg 17, 109, 119, 126-7, 128, 153-4, 163-4, 176, 178, 181, 195-7, 198, 199

fashion, see femininity: clothing

Faurisson, Robert 30, 36

Felloni, Madeleine: Voyage en enfer 54, 89

Felman, S.: Testimony 18, 20

female body 104, 121-9; abortion 137; breasts 121; gynaecological examination 125-6, 215; hips 121; menstruation 104, 122; motherhood 104, 136-40; nudity 122-5; sterilisation 139

femininity: appearance 130-3; clothing 130-3, 147; de-feminisation 110-13; hair shaved 125-6; housework 133-6; knitting 143; make-up 132; recipes 133-6; re-feminisation 110-13

Fénélon, Fania: Sursis pour l'orchestre 34, $37,53,57,92,96,108,117-19$, $121,122,131-2,149,166,176$, 181, 198-9

'Final Solution of the Jewish Question' 31

Finney, Patrick: 'Ethics' 32-3

flashbacks 21

Foley, B.: 'Fact, fiction, fascism' 62, 63-4, 66

footnotes 55-6

Frankfurt trial (1964) 65

Free French 169

Fresnes 17, 23, 130, 161

Friang, Brigitte: Regarde-toi qui meurs 16, $38,55,64,65,89,92,95,106,109$, $110,121-2,124,127-8,132$, $133-4,151,168,171,173$ 


\section{Index}

Friedlander, Judith: 'Anti-Semitism in France' 206-7

Friedlander, Saul: 'Probing the limits of representation' 30

'Galilée' 16

Galinski, Edward ('Edek') 34, 35

Gaulle, Charles de 36, 140, 169, 170, 172,173

Gaulle-Anthonioz, Geneviève de: $L a$ Traversée de la nuit $24,55,57,89$, 165,170

gender 103-41, 215-18; see also sexuality

German nationals 150-2, 165

Gervereau, L.: La Déportation 154

Gestapo 127

Gilbert, Martin: Holocaust 34

Goering, Hermann 66

Goethe, Johann Wilhelm von 151

Gorce, Nelly: Journal de Ravensbrück 58, 59-60, 67, 155, 158, 191

Gouri, Haïm 12

Grand, Odile: Couleur citron, cote coeur $176,177,178,179,180$

Grand Guignol 95-6

Grand Prix Vérité 39

Grazlitz 23

Grinspan, Ida: J'ai pas pleuré 11, 12, $34-5,43,47,48,176,179,180$, 185, 197, 202-3, 204, 205-6, 211

Guillemin-Ducret, Denise: Matricule 19374, afin que nul n'oublie 16, 18, 53, 167

Guillerme, Marc le: Hors la vie 10, 17, 54-5, 58, 59-60, 96, 115, 116, 120, 135, 136, 162, 170, 182, 186

Guyon-Belot, Raymonde: Le Sel de la mine 144-5

gynaecological examination, see female body

gypsies 146

Hartman, G. H.: The Longest Shadow 25; 'Public memory and modern experience' 25

Hasag 144

Hautval, Adélaide: Médecine et crimes contre l'bumanité 139, 188

health, see female body

Heftler, Nadine: Si tu t'en sors 18, 22, 48,
$53,54,55,80,88,90,148,151$, $166,176,180,184,185$

Heinemann, M.: Gender and Destiny 76

history: memory and 22-5, 25-8, 28-30

Hitler, Adolf 97, 132, 151, 153, 156, 193

Hochhuth, Rolf 97

Hoess, Rudolph 34, 66

Hollander-Lafon, Magda: Les chemins $d u$ temps $17,48,53,58,176,180,181$, 185

Holleischen 23, 95, 110, 128, 143, 144, 183

Holocaust: representations of 25

Holocaust (television) 36

Holocaust denial, see negationism

Holocaust studies 2, 3, 4-5; gender approach 103

Holstein, Denise: 'Je ne vous oublierai jamais, mes enfants d'Auschwitz' 176, $177-8,179,180,183,197,201$, 203, 204

homosexuals, see sexuality: gay men

Horowitz, S. R.: 'Memory and testimony of women survivors' 104-5; 'Rethinking Holocaust testimony' 20, 21

Hugo, Victor: Notre-Dame de Paris 96

Huk, Cécile: Et le Ciel resta bleu 81, 90, 94-5, 144, 160-1, 164, 168

humour 84-8, 142, 144

Hungarians 41, 122, 186, 190

Ikor, Roger 48

'imagined communities' 205-9

inaccuracies, see errors, factual

incorporation 48

indifference, reader 14; see also publication and reception

indiscipline 142-5

information, writing to provide $43-4$

'International, The' 173

interrogation 16,18

intertextual allusions 88-99

irony 84-8

'Israelites', see Jews

Italians 145

jails, French: women held in 161, 165

jargon 56

Jeannin-Garreau, Eliane 55; Les Cris de la 
mémoire 56, 128-9, 162, 170; Ombre parmi les ombres $21,49,79,80,143$, $144,167,183$

Jehovah's Witnesses 41, 71, 145

Jenkins, Keith: On 'What is History?' 29; The Postmodern History Reader 29-30; Re-Thinking History 30

Jews 2, 146, 148-9, 167, 176-209; babies killed 137; French citizenship revoked 202; German half-Jews 186; Hungarian 41, 122, 186, 190, 193; 'Israelites' 192-3, 193-200, 207; 'Jewish file' 1; 'Jewish memory' 35-6, 37, 64; Jewish Statute 177, 207; 'Juives' 200-5; kosher food 203; numbers 2; Polish 193, 198, 199; Rhodes 61; Russian 198; schoolchildren 178; texts 177, 192-205; Yom Kippur 204; see also anti-Semitism; Holocaust studies; negationism

Journal de Bergen-Belsen (1995) 53

Journal officiel 177

journals $10,37-9,58-63$

Jugendlager 182-3

'Jules'/'Julots', see sexuality: lesbian

Kagan 34

kapos 106

Klarsfeld, Serge 2, 24, 40, 55, 56

Klein, SS officer 87

Knoll, Käte 129

La Fontaine, Jean de 143

La Roquette 114, 120, 161

labour 23; avoiding 143; forced 142; hard 126-30; payment 144; pink card 182

LaCapra, Dominic: History and Memory after Auschwitz 28-30; History, Theory, Trauma 4-5, 29, 97

Lagrange, Simone: Coupable d'être née 43, 54, 55-6, 124, 128, 137, 138, 176, $177,178,179,180,181,183,184$, 185-6, 190; Libre parmi les morts 48, 95, 191; Les Rachetées 173, 175; 'Visions d'un camp de concentration' 44, 129, 146-7

Lahaye, Simone: 'Visions d'un camp de concentration' 189
Lang, Berel: 'Is it possible to misrepresent the Holocaust?' 31-2

Lang, Fritz: Metropolis 97

Langer, L. L. 65, 71, 212; 'Gendered suffering?' 103; Holocaust Testimonies 18-22; Versions of Survival 90

Langevin, Hélène 186

language 51-69

Laska, Vera: Women in the Resistance 113

Lasnet de Lanty, Henriette: Sous la scblague $43,45,47,53,55,56,68$, 72, 84-5, 109, 127, 131, 132, $135-6,143,146,152-3$

Laub, D.: Testimony 18, 20

laundry 135

Lavergne, Bernard 44

Le Pen, Jean-Marie 30

Leguay 36

lesbianism, see sexuality

Lesèvre, Lise: Face à Barbie 16, 38, 45, $48,53,55,94,95-6,128,131,146$, $151,153,187$

Levi, Primo 2; If This is a Man 13

Lévinas 25

Lévy-Osbert, Liliane: Jeunesse vers l'abîme $3,34,46,52,54,72,85,98,124$, $139,148-9,152,176,178,180$, $181,184,185,186$

Lewinska, P.: Vingt mois Auschwitz 160

lies 33-5

Limmer 23, 144

linear narrative $57-8$

Lipstadt, Deborah: Denying the Holocaust 31

London, Lise: La Mégère de la rue Daguerre 110,144

Lorge, Jehanne: Déportée pour une injure $22-3,52,86,89,94,127,131,142$, 167

Louria, Renée: Les Russes sont à Lemberg $89,107,137,176,180,184,202$, 204

Ludwigsberg 143

Lyons 23

Lyotard 3

'Madame Séverane' 16 Maechler, S.: The Wilkormirski Affair 33 make-up, see femininity Malchow 23, 110, 111 


\section{Index}

Mallet, Mireille: Sous le signe du triangle $53,81,122,125,167$

Maous, Françoise: Coma 39, 49, 51, 52, $53-4,55,67,80,149,153,172$, 176,193

maps 56

Marandin, Henri 22-3

Marette, Fanny: J'étais le numéro 47.177 $44,53,54-5,58,59,60,109,125$, 130,132

Marijo 98

Marmor, Tosca: Le Piano rouge 21-2, 37, $46,53,64,65,176,181,185,197$, 201, 202

'Marseillaise, La' 67, 68, 132, 173, 194, 195, 204, 205, 217

Marseilles 23; La Baumette prison 194

Martin-Champier, G.: Nuit et brouillard 53, $56,68,85,91,94,95,96,97,106$, $112,113,117,132,143,144,147$, 150, 151, 153, 156, 158-9, 186, 192

masturbation, see sexuality

'matricule' 18

Matricule 55310: Birkenau 54, 77

Maurel, Micheline: Un Camp très ordinaire $16,38,79,109,110,114,125,133$, $145,152,155,158,165,169$

Mauriac, François 55, 114

Maurice, Violette: Les Murs éclatés 24, 46, 91, 188-9; N.N. (1946) 40, 41, 53, $56,58,71,72,88,96,112-13,127$, 130, 143, 147-8, 188, (1995) 41;

Résurgences 21, 24, 45, 49, 93-4

Mauthausen 106; brothel 108-9

Mauvais, Yvette 186

medical experiments 55, 139

memoirs 63-5

memory: common 18-19, 22; deep $18-19,20,21,22$; exemplary 27-8; history and 22-5, 25-8, 28-30; literal 27-8

Mengele, Dr 184

metaphor 88-99

Mitterrand, François 1, 36

Montluc 123, 135, 189

Mori-Perrin, Josette de: Pour que demain soit liberté $11,12,17,48,52,53,76$, 86, 139, 144, 168-9

Morrison, J. G.: Ravensbrück 108, 128, 145-6, 154, 155, 182, 183, 187 motherhood, see female body

motivation 42-50

Moulin, Jean 1, 36

names, false $15-16$

national identities 142-60

Nazi-Soviet non-aggression pact 171

negationism 30-3, 36, 39, 43, 46

Neubrandenbourg 152

Neuebremm 95

Neumann, Bernd 64-5

Neustadt 23

Neuwirth, Lucien 55

New York Post, The 211

Nocher, Jean 40, 55

Nordman, Marie-Elisa 172

notes 10, 37-9

Novac, Ana: Les beaux jours de ma jeunesse (J'avais quatorze ans à Auschwitz) 18 , $37,58,60-3,90-1,144,152,156$, $165,180,201,202,212$

nudity, see female body.

oral testimony $12,20,22$

organisational 147

Ourisson, Douria: Les Secrets du bureau politique d'Auschwitz 34, 176

Pagniez, Yvonne: Ils resusciteront d'entre les morts 91; Scènes de la vie de bagne 54, 74, 79, 89, 93, 96, 97, 110, 111, $112,121,122,138,152,186$

Papon, Maurice 1, 36 paradox 52-3

paratext 55-6, 151

Paris 127; Cimetière des Innocents 96

Parisien Libéré, Le 39

patriotic addresses 78-9

Paul, Sylvie: Ne me jugez pas 64, 65, 127, 128, 161, 189

Péan, Pierre: Une jeunesse française 36

Pétain, Philippe 1, 205

photographs 55-6

Picard, Juliane: Des ténèbres à la lumière $12,39,46,58,69,125,153,159$, $176,185,198$

'Pierre, father' 1

Pilsudski, Jozef 159

pink card 182

Piper 154 
Index 253

Pithiviers 180, 199

Plaszow 37

Poirot-Delpech, Bertrand: J'ai pas pleuré $11,12,34-5,43,47,48,176,179$, $180,185,197,202-3,204,205-6$

Poland: 'Great Emigration' 157; November Uprising (1830) 157; 17, 80, 145, 146, 165; French and 152-60; Jews 193, 198, 199

political correctness 218

politiques 166-9; definition 166-7; Communists 169-75; numbers 2

Pollak, Michael: L'Expérience concentrationnaire 35, 83-4

Pollard, Miranda: Reign of Virtue 134, 136

Postel-Vinay, Anise 55

postmodernism 11, 28, 29, 30

prefaces 55-6

pregnancy, see female body: motherhood prisoner-functionaries $80,105,106,147$, $150-2,165$

pronouns $78-84$

prostitutes 161, 167; see also brothels

publication 35-6, 39-40; see also reception

punishment 126-30, 145, 215

racism 46; French 149-60; see also antiSemitism

Raguhn 23

Raisko 107, 165-6, 172, 217

rape, see abuse, sexual

Rassinier, Paul 30

Rastadt 129

rationing 134

Ravensbrück: aptitude test 143;

Auschwitz compared with 182-7;

Camp Newspaper 131; children 139, 191 ; Communists in $170,172,173$,

175; death march 65; gas chambers 183 ; Jews in 190, 192, 195;

lesbianism 117, 119; numbers 154, 155; 'political' prisoners 2; social hierarchy 165; Strafblock 116; trial of personnel 129

realisation 25

reception 14-15, 35

Reiter, A.: 'Literature and survival' 66-7; 'Narrating the Holocaust' 97;
Narrating the Holocaust 57, 58, 63-5, $71,84,93$

Rémy 55

Renault, Maisie: La Grande Misère 51, 55, $124,126,155$

Rennes 23, 161

reportage 11

republicanism 205-9

Resistance 1, 16, 36, 46, 56, 75, 104, $164,167,168,169-75,181,195$

resolution $66-9$

revisionism 46

reworking of material, see amendments

Rhodes 61

Richeling 23

Richet, Jacqueline 40

Ricoeur, Paul: La Mémoire, l'bistoire, l'oubli 10-11, 14, 45, 47

Ringelheim, J.: Different Voices 103-4

Romainville 89, 147, 161, 189

Roques, Henri 30

Rossinante, Madame 167-8

Roth, J.: Different Voices 103-4

Rouen 23, 161

Rousset, David 2, 174, 175

Rousso, H.: Le Syndrome de Vichy 36, 210-11; Vichy 1, 26, 27, 206

Roux, Catherine: Triangle rouge (1946) $14,15,16,49,53,75,68,81,86$, $91,95,127,132,159-60,186$, (1950) 48

sabotage 142, 143, 144

Sachsenhausen 108

Saint-Clair, Simone: Ravensbrück (1945) $41,42,47,54,56,58,60,67,68$, $73,74,91,108,111,115,120-1$, $151,155,165,173,183,(1966) 41$, 42

Sampaix, Mme 186

Sarrebrück 135

Sartre, Jean-Paul: Réflections sur la question juive 190

Schapira, Charlotte: Il faudra que me souvienne $15,43,54,81,53,125,131$, $136,138,176,177,178,179,180$, 197, 201, 203, 205

Schneider, Romy 64

Schönfeld 143

schools, see education 


\section{Index}

Schumann, Maurice 40, 55

Schumman, Doctor 139

Schutzstaffel (SS) 23, 46, 56, 65, 80, 92, $94,124,127,146,150-2$; female $129,131,215$

screens 25

segregation of sexes 105

self, writing for the 48-50

self-objectivation $16,17-18$

self-representation 142-9

Semprun, Jorge: L'Écriture ou la vie 2, 52, $69,99,214$

Serre, Charlotte: De Fresnes a Ravensbrück $12,53,143,145$

Séverin, M. J. 11

sexuality $103-41,215-18$; bartered sex 105, 107, 117, 118; French STOs

110,111 ; gay men 113,146 ; guards 77, 105, 106; homophobia 114-15, 116; lesbian 104, 105, 113-21, 125, 215; male-female relations 104 , 105-13; masturbation 107, 114; power and 105-10; supportive relationships 110-13; see also abuse, sexual and female body

Shoah, see Holocaust

Siemens 143

Silverman, M.: 'Jews, Arabs' 190

Simier, Lucienne: 2 ans de bagne à Ravensbrïck 54, 81, 86, 89, 142, 167, 187

'Simone, la capitaine': Moi, un cobaye 77-8, 139

Six Day War 36, 64

Skoda 143

Sofsky, W.: The Order of Terror 107, $145-6,165$

Soviet camps 174, 175, 217

Stalag IV.C 110-11

Stalin, Joseph 173

stealing $147-8$

sterilisation, see female body

structure, narrative 57-69

'Stücken' 18

Suez Crisis 64

Sullivan, Pierre 66, 195

Switzerland 42

Taube, Anton 211

tenses $70-3$ terminology 56

Terre de cendres (1946) 54

testimonio 62-3

third-person narrative 17

Tiananmen Square 45

Tichauer, Eva: J'étais le numéro 20932 à Auschwitz 47, 48, 54, 67, 81, 97-8, $107,109,140,150,156,158,172$, $176,178,180,185,197,201-2$, 204, 205

Tillion, Germaine: Ravensbrück 143, 157, $160,165,169,182$

time-span 57-8

titles 53-5

Todorov, T. 27, 45; Les Abus de la mémoire 26, 27-8, 175; Facing the Extreme 175 tone $73-8$

Torgau 23, 110-11, 112, 132, 183

torture 126-30

Touboul, Camille: $U n$ relais d'étoiles (Le plus long des chemins) 24, 34, 40, 41-2, 46-7, 53, 68, 79-80, 91, $128,129,153,176,178,180,181$, $184,185,195$

Toulouse-Lautrec, Béatrix: La Victoire en pleurant (1967) 11, 25, 39, 53, 68-9, $74,81,85,110-11,123,135,143$, $150,158,161,165,167-8,170$, 189,191

Tours 23

Touvier, Paul 1, 36

transactive processes 25

transmettre 24-5, 26, 213

truth 9-13; contractual 14; defined $10-11,23,30$

Tubeuf-Branchu, Yvonne: Récit de ma déportation 167, 183

Uckermark 182-3

UGIF 180

Vaillant-Couturier, Marie-Claude 186, 187

Valois, Eugénie: Ceux qui n'ont pas eu vingt ans 14,139

Vartan, Sylvie 64

Vel d'Hiv 1, 202, 206

'Verfügbar' 142, 143

Versailles, Treaty of 201

Vichy 56, 134-5, 206; French obsession with 1; gender roles $126,136-7,140$; 
Index 255

and Jews $177,194,208$; trials of functionaries 1,36

Vidal-Naquet, Pierre 22, 39, 48, 55, 193

Vietnam 64

violence $126-30$

Wall Street Crash (1929) 156

Wannsee conference 31-2

warning: writing as 44-5, 151

Warsaw 152-3

Wiesel, Elie 2, 55

Wieviorka, Annette 29, 55; Déportation ou génocide 25, 35-6, 43, 77, 198, 204-5; L'Ere du témoin 12, 26, 36; 'Indicible ou inaudible?' 89; 'On testimony' 176
Wilborts, Suzanne: Pour la France 11, 17, $44,53,68,74,76-7,79,80,81,86$, $92,98,108,130,146$

Wilkomirski affair 33

women, see female body; femininity; sexuality

work, see labour

Young, James: 'Interpreting literary testimony' 49-50, 62; Writing and Rewriting the Holocaust 51, 76

Yugoslavia 170

Yuval Davis, N.: 'Jews, Arabs' 190

Zimetbaum, Mala 33-5

Zwodau 23, 38, 162, 173 


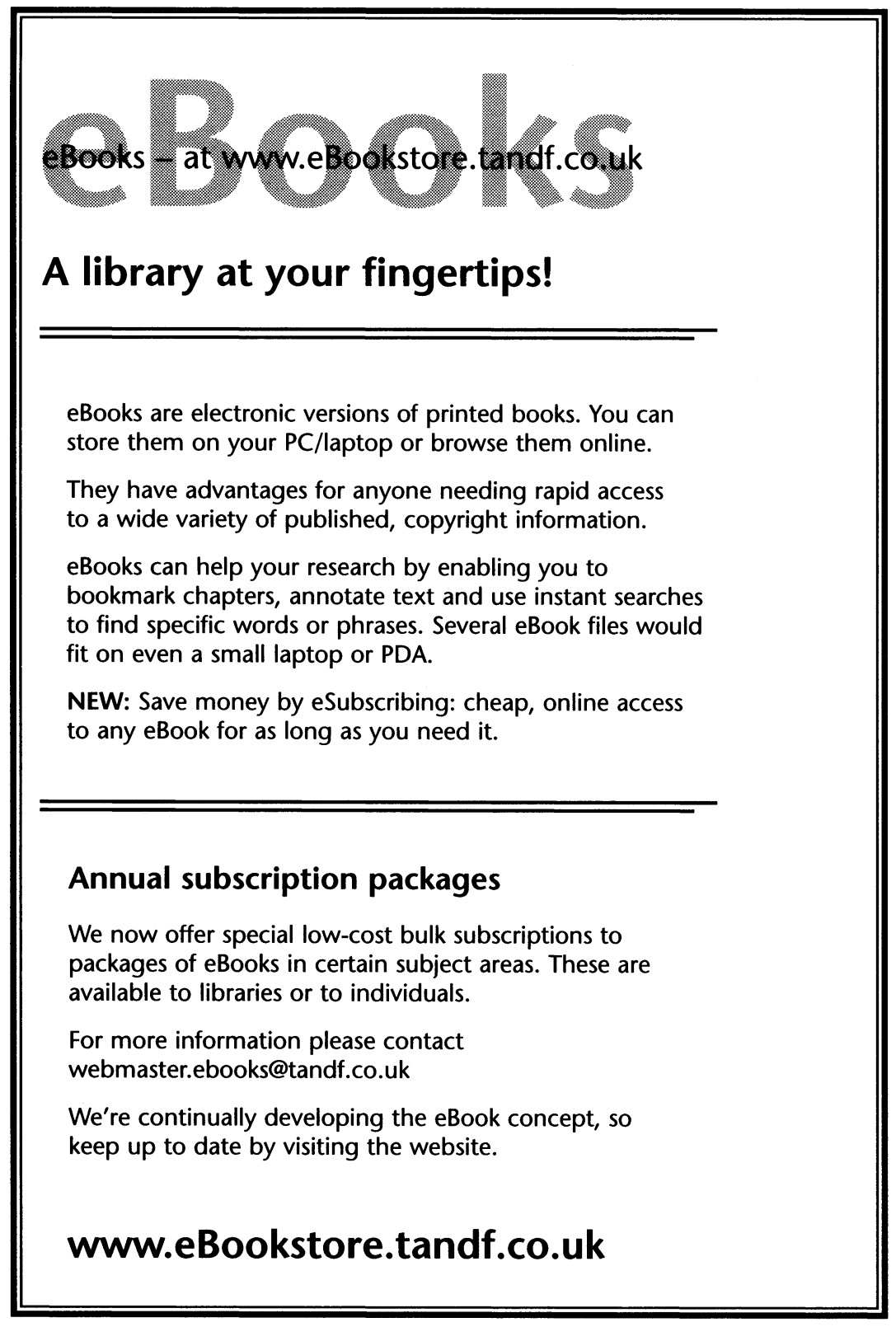



